\title{
PERFORMANCE AND CHARACTERISTICS OF CANADIAN ACQUIRING
}

FIRMS

\section{BY}

\author{
Shantanu Dutta, B.Tech., M.E.M., M.B.A.
}

\author{
A thesis submitted to \\ The Faculty of Graduate Studies and Research \\ in partial fulfillment of the requirements for the degree of \\ Doctor of Philosophy
}

\author{
Eric Sprott School of Business \\ Carleton University \\ Ottawa, Ontario
}

\author{
September 12,2006 \\ (C) Copyright \\ 2006, Shantanu Dutta
}




$\begin{array}{ll}\begin{array}{l}\text { Library and } \\ \text { Archives Canada }\end{array} & \begin{array}{l}\text { Bibliothèque et } \\ \text { Archives Canada }\end{array} \\ \begin{array}{l}\text { Published Heritage } \\ \text { Branch }\end{array} & \begin{array}{l}\text { Direction du } \\ \text { Patrimoine de l'édition }\end{array} \\ \begin{array}{l}\text { 395 Wellington Street } \\ \text { Ottawa ON K1A ON4 }\end{array} & \begin{array}{l}\text { 395, rue Wellington } \\ \text { Ottawa ON K1A ON4 } \\ \text { Canada }\end{array}\end{array}$

Your file Votre référence ISBN: 978-0-494-18215-4 Our file Notre référence ISBN: 978-0-494-18215-4

NOTICE:

The author has granted a nonexclusive license allowing Library and Archives Canada to reproduce, publish, archive, preserve, conserve, communicate to the public by telecommunication or on the Internet, loan, distribute and sell theses worldwide, for commercial or noncommercial purposes, in microform, paper, electronic and/or any other formats.

The author retains copyright ownership and moral rights in this thesis. Neither the thesis nor substantial extracts from it may be printed or otherwise reproduced without the author's permission.
AVIS:

L'auteur a accordé une licence non exclusive permettant à la Bibliothèque et Archives Canada de reproduire, publier, archiver, sauvegarder, conserver, transmettre au public par télécommunication ou par l'Internet, prêter, distribuer et vendre des thèses partout dans le monde, à des fins commerciales ou autres, sur support microforme, papier, électronique et/ou autres formats.

L'auteur conserve la propriété du droit d'auteur et des droits moraux qui protège cette thèse. $\mathrm{Ni}$ la thèse ni des extraits substantiels de celle-ci ne doivent être imprimés ou autrement reproduits sans son autorisation.
In compliance with the Canadian

Privacy Act some supporting forms may have been removed from this thesis.

While these forms may be included in the document page count, their removal does not represent any loss of content from the thesis.
Conformément à la loi canadienne sur la protection de la vie privée, quelques formulaires secondaires ont été enlevés de cette thèse.

Bien que ces formulaires aient inclus dans la pagination, il n'y aura aucun contenu manquant.

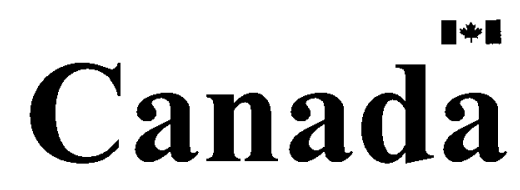




\begin{abstract}
This study empirically examines the short- and long-term performance, and the differentiating characteristics of acquiring firms by using a comprehensive sample of 1300 Canadian acquisition events during the period of 1993-2002. With respect to shortterm abnormal returns, we find that, overall, there is a positive and significant abnormal return for Canadian acquiring firms' shares around the announcement date. This finding is different from the ones reported in most of the U.S. studies and we attribute this observation to deal-specific characteristics and the regulatory environment in Canada. However, these abnormal returns become statistically insignificant within 15 days of the announcement. Thus, it appears that initially market participants overreact to acquisition announcements. We also find that the stock market reacts more favourably to (i) unrelated acquisitions; (ii) relatively larger deals; (iii) deals involving target firms from outside Canada and the U.S.; (iv) deals involving private targets; (v) deals with higher target premiums, and (vi) deals by acquiring firms with higher levels of managerial ownership.
\end{abstract}

With respect to long-term stock return performance, we find that once we combine the findings of an event-time approach and a calendar-time approach, there is no strong support for positive long-term abnormal returns for acquiring firms that are robust across all methodologies. Our findings suggest that buy-and-hold abnormal return (BHAR) results vary significantly with benchmark choices, and Fama-French (F-F) regression models fail to explain satisfactorily the stock returns in many instances. We also do not find any improvement in long-term operating performance in general, once we adopt the matching firm approach and results vary according to methodological choices. However, we find that long-term operating performance increases significantly for the relatively larger deals and the market reacts more favourably to those deals around the announcement date. This implies that only relatively larger deals bring economically significant benefits to the acquiring firms and the market recognizes this aspect.

Finally, we investigate the differentiating characteristics between acquiring and nonacquiring firms. Our results show that with respect to 'firm specific variables', firms with higher cash reserves, better past performance, and higher R\&D focus (high-tech firms) are more likely to be acquirers. With respect to the governance variables, we find that acquiring firms have higher pay ratios ((option pay + option value) / by cash pay), lower inside director ratios, higher board sizes and lower blockholder ownership. We also find support for the conjecture that CEO hubris levels are significantly higher for the acquiring firms. 


\section{ACKNOWLEDGEMENTS}

I wish to express eternal gratitude and deep appreciation to my thesis supervisor, Prof. Vijay Jog, who has played a key role at every stage of this study with conceptual discussions and appropriate guidance. I would like to pay special tribute to him, in particular, for his meticulous attention to the details of report organization and continuous encouragement throughout the research study. It was a great pleasure for me to conduct this thesis under his supervision. Thank you Prof. Jog, for your kind support and encouragement.

I am greatly indebted to Prof. Roland Thomas for his constant support and invaluable advice, which has inspired me during my studies at Carleton. His classes and discussions were immensely helpful. I am also grateful to Prof. Al Riding for his valuable comments and meaningful discussions, which has influenced me in carrying out this research work. Moreover, I would like to thank Prof. Rajeeva Sinha and Prof. Patrick Farrell for taking out time to be on my thesis committee.

I owe to all teachers a great deal, whose magnificent generosity helped me to come so far. I am especially thankful to Prof. Vinod Kumar and Prof. Uma Kumar for their support and encouragement during my stay at Carleton. Further, I greatly appreciate the help and support of Janice Walker, the graduate secretary, who is extremely prompt and caring.

I would like to thank my colleagues at the Business Administration Department, St. Francis Xavier University, for their encouragements and providing me with a stimulating environment. My special gratitude goes to Ken and Tim for reviewing the draft and making some thoughtful comments. I am also thankful to Wendy for revising the English of my manuscript.

During my stay in Ottawa, many friends offered practical and emotional support that helped me immensely in completing the Ph.D. program. Especially I would like to thank Shavin, Phil Zhu and Kamel for extending their friendship and support. I have also enjoyed the warm friendship of Badal, Shaheen, Dulal, Bhasker, Miwako and Okumura during my stay in Ottawa.

I gratefully acknowledge the continuing patience and encouragement of my beloved parents and brothers whose love and support have encouraged me in all my worthwhile pursuits throughout the life. Finally, I am thankful to my wife, Ila, and daughter, Moumita, for their tremendous sacrifices and patience. Without their love and support it would have been extremely difficult to complete this work and I dedicate this thesis to them.

I acknowledge the financial supports from the Ontario Graduate Scholarship to this research. 


\section{TABLE OF CONTENTS}

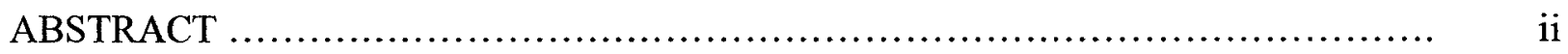

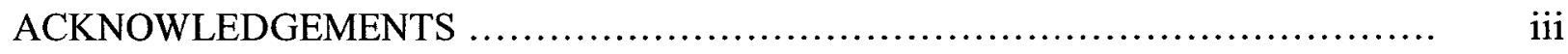

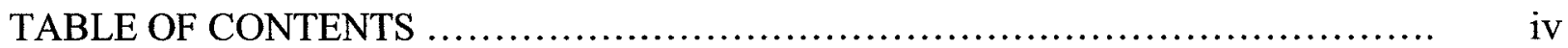

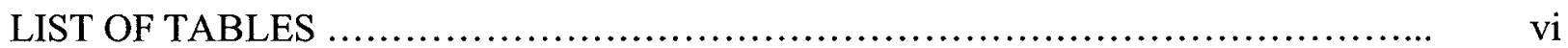

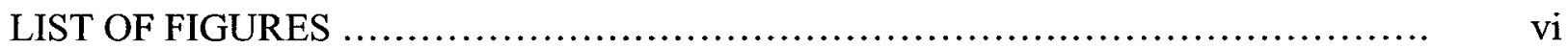

CHAPTER 1: INTRODUCTION .....................................................

CHAPTER 2: LITERATURE REVIEW ....................................... 12

2.1 Performance of Bidding Firms: Short and Long-Term Perspectives............... 13

2.1.1 Background .................................................................... 13

2.2 Factors Affecting the Acquiring Firms' Short and Long-Term Performance....... 16

2.2.1 Theory/Conjectures ........................................................... 17

2.2.2 Empirical Evidence for Acquiring Firms' Short-and Long-term Performance... $\quad 27$

2.3 Firm Specific and Governance Characteristics of Bidding Firms .................. 29

2.3.1 Motivation ................................................................. 29

2.3.2 Firm Specific Characteristics ............................................ 31

2.3.3 Governance Characteristics ................................................. 34

2.3.4 Empirical Evidence ..................................................... 39

CHAPTER 3: RESEARCH METHODOLOGY ..................................... 41

3.1 Hypotheses .................................................................. 41

3.1.1 Short-term and Long-term Performance of Acquiring Firms .................... 41

3.1.2 Differentiating Characteristics of Acquiring Firms .......................... 42

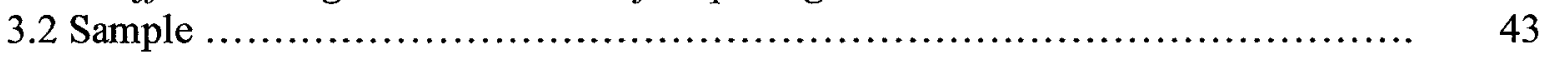

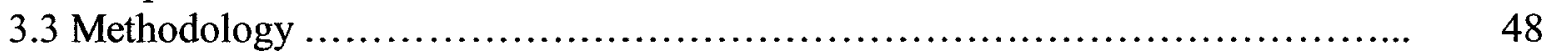

3.3.1 Short-term Performance Issues ............................................. 48

3.3.2 Long-term Stock Return Performance Issues ................................. 49

3.3.3 Evaluating Long-term Operating Performance ................................. $\quad 50$

3.3.4 Differentiating Characteristics of Acquiring Firms ........................... 51

CHAPTER 4: RESULTS: SHORT-TERM ABNORMAL RETURN FOR ACQUIRING FIRMS …............................................................ 52

4.1 Short-term Performance for an Acquisition Event.............................. 52

4.2 Factors Affecting Acquiring Firms' Short-term Performance ..................... 55

4.2.1 Univariate Analysis ...................................................... 56

4.2.2 Multivariate Analysis .................................................... 64

CHAPTER 5: RESULTS: LONG-TERM STOCK RETURN PERFORMANCE .......... 74

5.1 Long-term Return Performance for an Acquisition Event........................ $\quad 74$

5.2 Factor Affecting the Acquiring Firms' Long-term Performance...................... 82

5.2 .1 Event-time Approach: Univariate Analysis ................................... 83

5.2.2 Event-time Approach: Multivariate Analysis .................................... 95

5.2.3 Calendar-time Approach: F-F Three Factor Model ......................... 101 
CHAPTER 6: RESULTS: LONG-TERM OPERATING PERFORMANCE ............ 105

6.1 Pre- and Post-acquisition Operating Performance ......................... 105

6.2 Relationship among Long-term Operating Performance, Long-term Stock Return Performance, and Short-term Abnormal Return

CHAPTER 7: RESULTS: DIFFERENTIATING CHARACTERISTICS BETWEEN ACQUIRING AND NON-ACQUIRING FIRMS ..................... 112

7.1 Firm Specific Variables .................................................. 114

7.2 Governance Variables ................................................... 118

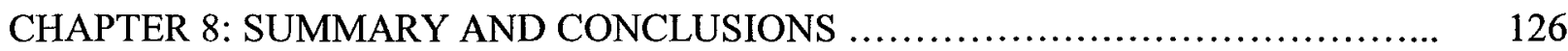

CHAPTER 9: CONTRIBUTIONS, LIMITATIONS, AND SUGGESTIONS FOR FURTHER RESEARCH .

9.1 Major Contributions of the Study ...................................... 131

9.2 Implications for Market Participants and Researchers ........................ 133

9.3 Limitations ................................................................ 136

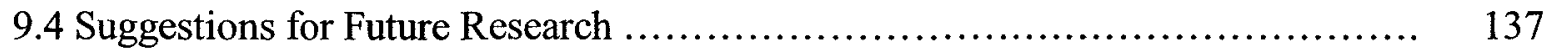

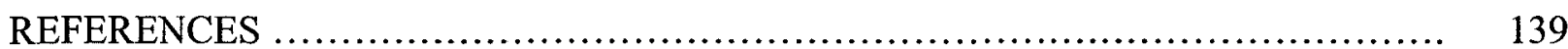

APPENDIX A: STRUCTURAL CHANGES IN M\&A MARKET IN THE 1990S ..... 151

APPENDIX B: STATE OF M\&A LITERATURE: A SNAPSHOT .................... 153

APPENDIX C: SHORT TERM PERFORMANCE STUDIES ......................... 157

APPENDIX D: LONG TERM PERFORMANCE STUDIES ........................ 162

APPENDIX E: EMPIRICAL STUDIES INVESTIGATING THE CHARACTERISTICS OF TARGET FIRMS ...................................... 173

APPENDIX F: METHODOLOGICAL ISSUES IN SHORT-TERM PERFORMANCE

EVALUATION ................................................ 176

APPENDIX G: METHODOLOGICAL ISSUES IN ESTIMATING LONG-TERM PERFORMANCE .............................................. 182

APPENDIX H: METHODOLOGICAL ISSUES IN DETECTING THE DIFFERENTIATING CHARACTERISTICS OF A BIDDING FIRM..... 194

APPENDIX I: PRELIMINARY DOCUMENTATION OF CANADIAN M\&A ACTIVITY

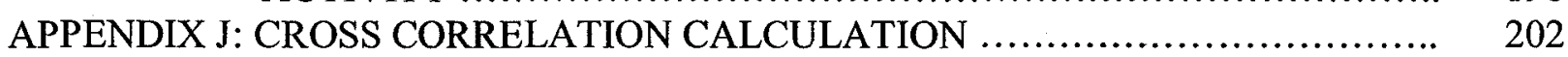

APPENDIX K: COMPARISON OF OVERLAPPING AND NON-OVERLAPPING ACQUIRING FIRMS' CHARACTERISTICS ....................... 204

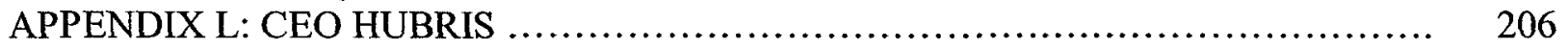

APPENDIX M: VARIABLE NAME AND DESCRIPTION ........................ 213 


\section{LIST OF TABLES}

Table 2.1 Factors Affecting Bidding Firms' return: Summary of Empirical Evidence ...... $\quad 27$

Table 3.1 Hypotheses for Short and Long-Term Performance for Acquiring Firms ........ $\quad 41$

Table 3.2 Yearly and Sectoral Distribution of Canadian Acquirers Listed on Toronto

Stock Exchange ....................................................... 44

Table 3.3 Descriptive Statistics of Firm-Specific Variables and Governance Variables and Deal-Specific Variables for Acquiring and Non-acquiring Firms .......... 45

Table 4.1 Short-run Daily Abnormal Return: Market Model ......................... 54

Table 4.2 Short-run Cumulative Abnormal Return: Market Model ....................... 55

Table 4.3 Factors Affecting Short-term Performance - Univariate Results .............. 56

Table 4.4 Factors Affecting Short-term Performance - Multivariate Analysis .............. 65

Table 4.5 Summary of the Short-term Performance Hypotheses Test Results ............ 72

Table 5.1 Buy and Hold Abnormal Return (BHAR) Considering All Acquisition Cases

(Overlapping and Non-overlapping Cases) ............................... 77

Table 5.2 FF 3-factor Regression with All Cases ................................... 79

Table 5.3 FF 3-Factor Regression for Non-overlapping and Overlapping Cases .......... $\quad 81$

Table 5.4 Factors Affecting Long-term Performance - Univariate Analysis ............... 83

Table 5.5 Factors Affecting Long-term Performance - Multivariate Analysis ............ 96

Table 5.6 Long-term Abnormal Return for Various Factors Using F-F Three Factor Model .................................................................. 101

Table 5.7 Summary of the Long-term Stock Return Performance Hypotheses Test Results ............................................................. 104

Table 6.1 Operating Performance (Cash Flow to Total Assets) for Pre- and Post-Merger Period ................................................................. 106

Table 6.2 Regression on Pre-merger Performance .................................... 108

Table 6.3 Impact of Operating Performance and Short-run Performance on Long-run

Abnormal Return ......................................................

Table 7.1 Descriptive Statistics of Firm Specific Variables and Governance Variables for Acquiring and Non-acquiring Firms .................................... 113

Table 7.2 Differentiating Characteristics Corresponding to Firm Specific Variables ...... $\quad 116$

Table 7.3 Differentiating Characteristics for Governance Variables ...................... 120

Table 7.4 Analysis of the Impact of CEO Hubris on M\&A Decision ................... 123

\section{LIST OF FIGURES}

Figure 2.1 Expected Sign of Various Factors' Influence on a Bidding Firm's Short-term Abnormal Performance ......................................................

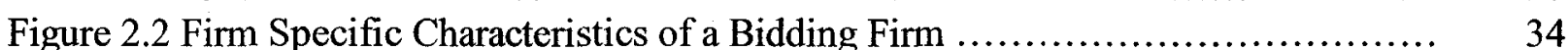

Figure 2.3 Governance Characteristics of a Bidding Firm ............................. 39 


\section{CHAPTER 1: INTRODUCTION}

Over the last two decades, Mergers and Acquisitions (M\&A) related issues have drawn considerable interest from practitioners and academicians. As a result, scores of empirical studies have documented various aspects of M\&A activity including trends in M\&A activity, characteristics of the transactions, and corresponding gains or losses to shareholders. The reasons for the continuing interest in this field are twofold. First, there is still a lack of consensus on a number of issues such as long-term performance, shortterm gains to acquiring ${ }^{1}$ firms, the impact of governance issues, and the relation between performance and the characteristics of targets and bidders, etc. Second, there have been significant changes in the Mergers and Acquisitions market over the last two decades, including: a shift in focus from unrelated to related targets, gradual changes in modes of payment, increasing evidence of friendly mergers as opposed to takeover bids, deregulation in certain industries, increased levels of foreign competition, and renewed focus on corporate governance issues. These changes have resulted in analysis with a much broader focus (please refer to Appendix A for more details on structural change).

In addition, it must be noted that many of these studies have been in the U.S. context and Canadian studies are very limited. The previous research using Canadian data include studies by Eckbo (1986), Eckbo et al. (1990), and Eckbo and Thorburn (2000), who investigate M\&A issues during the $1964-1983$ period, mostly focussing on the gain/loss to the bidders and target companies subsequent to M\&A, medium of exchange in

\footnotetext{
${ }^{1}$ In this study we use the terms "bidder" and "acquirer" interchangeably, as we consider only the completed deals in the analysis.
} 
takeovers and related consequences, and gain/loss to the foreign bidder vis-à-vis a domestic bidder. Smith and Amoako-Adu (1993) analyse the impact of exempt takeover offers on shareholders' wealth with a sample of 56 deals during the period between 1980 and 1989. St-Pierre (1994) investigates the takeover bid resistance and the managerial welfare hypothesis by considering 101 cash tender offers during the period of 1978-1987. Recently, Andre et al. (2004) investigate the long-term performance of Canadian acquirers and report significant underperformance. However, the sample size in their study is quite limited (143 events for non-overlapping stocks). Further, Yuce and $\mathrm{Ng}$ (2005) investigate the short-term stock-return performance of targets and acquiring firms around the announcement date and report significant positive abnormal returns for both groups.

This study focuses on the Canadian mergers and acquisitions market and its purpose is threefold: first, to investigate the short-term performance of acquiring firms and to identify the factors affecting the short-term performance; second, to investigate the longterm performance of acquiring firms and to identify the factors affecting the long-term performance; and third, to identify the characteristics of an acquiring firm that separate it from a non-acquiring firm, which in turn would shed light on the motives of M\&A activities. All the analyses are carried out considering the Toronto Stock Exchange (TSE)-listed bidding firms only. A fourth and equally important contribution of this study is our use of multiple methodologies as well as our use of different matching sample techniques. This allows us to test the robustness of methodologies on results; we believe 
that this definitely contributes to the richness of our conclusions. We describe this more thoroughly in chapter 3 .

The motivation behind the study is as follows. First, results of previous long-term performance studies need to be reviewed with the use of improved methodologies. Second, there is no consensus in the literature on the short-term performance of acquiring firms' stock returns. Also, for both long-term and short-term performance analyses, there is an opportunity to identify relevant factors that affect corresponding firm performance. Third, there is virtually no comprehensive study investigating the characteristics of an acquiring firm separate from a non-acquiring firm. An investigation of this issue would be of importance to shareholders as a bidding firm's stock returns are affected by such characteristics. This would also shed some light on the motives underlying acquisition activities. We not only look at performance characteristics, but also focus on governance variables; we believe that the latter set of variables has not been tested as thoroughly in the literature. Fourth, structural changes in the M\&A market as outlined in appendix A warrant a new study.

To conduct our analyses, we use a comprehensive sample of 1300 acquisition events between 1993-2002. An overview of the results and contributions of this study in the three areas of M\&A (namely short-term performance, long-term performance, and differentiating characteristics of an acquiring firm) is presented below. 
Since there have been relatively few studies investigating short-term abnormal returns of acquiring firms with Canadian data, this study makes some significant contributions in this area. First, except for Yuce and $\mathrm{Ng}$ (2005), other Canadian studies' results are based on pre-1990 data. Given the M\&A boom in Canada in the 1990s, it is interesting and important to revisit some of the earlier results. Second, this is the first comprehensive study to investigate the implications of governance factors on short-term performance for acquiring firms. Third, the study presents results from both univariate and multivariate analyses in order to assess the robustness of the results. With respect to short-term abnormal returns, we find that overall there are significant and positive abnormal returns for the Canadian acquiring firm' $\mathrm{s}^{2}$ shares around the announcement date. The results are robust across single acquirers and multiple acquirers ${ }^{3}$. This finding is different from the ones reported in most of the U.S. studies. The majority of the U.S. studies have reported either negative or insignificant abnormal returns for the acquiring firms around the announcement date (see Appendix C). However, the results observed in this study are not surprising in a Canadian context, as all of the earlier Canadian studies have reported significant and positive abnormal returns around the announcement date (Calvet and Lefoll, 1987; Eckbo, 1986; Eckbo \& Thorburn, 2000; Masse et al., 1990; Yuce \& Ng, 2005). Possible explanations for the difference in results between Canadian and U.S. studies are as follows: First, the majority of the Canadian acquisitions are made through cash payments, whereas in the U.S., the majority of the deals are made through stock payments (Eckbo \& Thorburn, 2000; Loughran \& Vijh, 1997). Due to information asymmetry and valuation uncertainty surrounding a stock acquisition, it has been argued

\footnotetext{
${ }^{2}$ We consider only Toronto Stock Exchange (TSX) listed firms.

${ }^{3}$ Multiple acquirers make more than one acquisition in a calendar year.
} 
that stock- financed deals are likely to be viewed less favorably in the market (Fuller et al., 2002; Myers \& Majluf, 1984). Second, antitrust regulation is more strict and developed in the U.S. than in Canada, which results in a less favorable reaction for U.S. acquiring firms' returns following an acquisition announcement (Yuce \& Ng, 2005). Further, it has been reported that U.S. firms more frequently adopt anti-takeover strategies such as shareholder's rights plan, poison pill, and shark repellent compared to Canadian firms, and in Canada, anti-takeover plans are typically rendered ineffective by the securities commission(s) at the request of the bidder. Due to the adoption of effective takeover deterrents by the target firms, acquirers' returns are lower in the U.S. (Brealey et al., 2006). Third, the size of U.S. acquiring firms is significantly larger as compared to Canadian acquirers. As a result, the relative size $e^{4}$ of acquisitions is higher in a Canadian context. Relatively larger deals carry more economic significance and lead to a more pronounced reaction in the market (Eckbo et al., 1990; Eckbo \& Thorburn, 2000). Fourth, we find that unlike the U.S. market, the Canadian market reacts positively to unrelated acquisition announcements recognizing diversification benefits (Eckbo \& Thorburn, 2000). In our sample, approximately $60 \%$ of the deals are unrelated. Fifth, there was a merger boom in Canada during the 1990s, when the market was taking a favorable note of M\&A activity (Crosbie \& Co. Annual Report, 1993-2001). Since the majority of the M\&A cases in this study falls within this time period, the positive abnormal returns may simply be due to the overall favourable reaction to large acquisitions in a buoyant market period. In support of the above discussion, this study finds that the market reacts more favorably for (i) unrelated acquisitions as compared to the related acquisitions, (ii) relatively larger deals as compared to relatively smaller deals, and (iii) cash financed

\footnotetext{
${ }^{4}$ Ratio of target size and acquirer size.
} 
deals. Further investigation of various deal- and firm-specific factors reveals that the Canadian market reacts more positively for (i) deals involving target firms from outside Canada and U.S., - considers the diversification effect, (ii) private targets as compared to public targets - considers the liquidity discount for the private targets and limited competition (Fuller et al., 2002), (iii) deals with higher target premium ${ }^{5}$ - considers that the targets are highly valued by the management, (iv) deals by acquiring firms with higher levels of managerial ownership - considers that management interest is aligned for such deals (Morck et al., 1988), and (v) announcements made by value firms compared to the growth firms - considers that a growth firm's management is arrogant and overpay for target firms (Hayward and Hambrick, 1997; Roll, 1986).

With respect to long-term stock return performance, this study makes an important contribution to the ongoing debate on the validity of existing long-term performance methodologies by carefully investigating different approaches ${ }^{6}$ employed to detect longterm abnormal returns. The results of our analyses are quite interesting as they expose the unreliability of earlier findings, which were heavily driven by methodological choices. Once we combine the findings of event-time approach (buy and hold abnormal return (BHAR)) and calendar-time approach (Fama-French (F-F) three factor regression) we do not find any strong support for long-term abnormal returns following an acquisition event.

\footnotetext{
${ }^{5}$ We view this result with caution as the sample size for target premium was low (92). Target premium was obtained only for the TSE listed target firms.

${ }^{6}$ In the Canadian context, only Andre et al. (2004) have investigated the long-term stock return performance for acquiring firms. However, the sample size was limited (143 non-overlapping cases) and they have used only the calendar-time approach.
} 
Given the controversy surrounding the long-term performance studies, we take several steps to check the robustness of the results. With respect to the buy and hold abnormal return (BHAR) approach, we use matching firm return as a benchmark (Barber \& Lyon, 1997) along with other benchmarks ${ }^{7}$. We also use skewness adjusted $t$ statistics (Lyon, Barber, \& Tsai, 1999); and we make adjustment for cross-sectional dependence in the test statistics (Mitchell \& Stafford, 2000). In the case of the F-F three factor regression approach (calendar-time), we take the following steps: first, we use three different samples with (i) all cases, (ii) non-overlapping $\operatorname{cases}^{8}$, and (iii) overlapping cases ${ }^{9}$ to isolate the effect of cross-sectional dependence (Lyon et al., 1999; Mitchell \& Stafford, 2000). Second, we use the weighted least square (WLS) procedure to account for acquisition activity weights in different months and to mitigate the potential heteroskedasticity problem (Andre et al., 2004; Franks et al., 1991) ${ }^{10}$. Further, we investigate a series of deal- and firm-specific and governance variables' impact on longterm stock abnormal returns, and report both univariate and multivariate results.

\footnotetext{
${ }^{7}$ Benchmarks such as market index and reference portfolios are subject to rebalancing and skewness biases (Barber \& Lyon, 1997). Moreover, these benchmarks ignore the size and book to market value factors (Fama, 1998).

${ }^{8}$ If a firm makes acquisitions within three years of a previous acquisition, the cases are considered "overlapping" and were deleted from this sample.

${ }^{9}$ Considered the cases when a firm makes one or more acquisitions within three years of a previous acquisition.

${ }^{10}$ However, there is no significant difference in result whether or not we consider WLS methodology while using value weight returns. Further, Mitchell and Stafford (2000) have shown that WLS methodology is not efficient in mitigating the heteroskedasticity problem.
} 
Our results do not demonstrate any strong support for negative long-term performance as reported in some of the earlier studies ${ }^{11}$. This interesting and significant finding leads us to the conclusion that the earlier studies reporting long-term underperformance should be viewed with caution for the following reasons: (i) investigations are generally carried out using one of the two approaches (event-time or calendar-time) and various adjustments discussed above are not considered, (ii) in case of the investigation of the deal-specific, firm-specific, and governance factors only univariate results are presented, which ignores the confounding effect, and finally, (iii) there still are controversies surrounding the longterm performance methodologies that may distort empirical results. For example, it is argued that the BHAR method lacks statistical power (Kothari \& Warner, 2005), and that the Fama-French three-factor approach suffers from a model specification problem ${ }^{12}$.

We further investigate the long-term operating performance of the acquiring firms using various methodologies. Like long-term stock return studies, operating performance results also depend on the choice of methodology. Following Healy et al.'s (1992) "industry adjusted operating performance" methodology, we observe a positive and significant long-term abnormal operating performance for acquiring firms. However, as Ghosh (2001) points out, the "industry adjusted operating performance" approach is flawed (as discussed in the subsequent chapter) and suggests using the "matching firm adjusted operating performance" approach. Following the matching firm approach, we do

\footnotetext{
${ }^{11}$ This finding reinforces the views of Fama (1998), and Mitchell and Stafford (2000). They argued that the long-term negative abnormal returns reported in the literature are "chance" results and are highly dependent on methodological choices.

${ }^{12}$ If the factors used in the model cannot explain fully the variation in stock returns, the validity of considering "alpha" or "intercept" as a measure of abnormal return is questionable. In other words, to validate the abnormal return results of the Fama-French three-factor approach (or the similar Jensen alpha approach), the model should show a very high R-square value.
} 
not find any strong support for long-term positive abnormal operating performance for Canadian acquiring firms ${ }^{13}$.

Subsequently, we investigate the differentiating characteristics between acquiring and non-acquiring firms. To the best of our knowledge, this is the first systematic and comprehensive study that investigates the differentiating characteristics of an acquiring firm. Our results show that with respect to "firm specific variables," firms with higher cash reserves, better past performance, and higher research and development (R\&D) spending (high-tech firms) are more likely to be acquirers. This implies that a firm with more financial resources is more likely to be an acquirer. Moreover, hi-tech firms are more likely to make acquisitions in order to stay innovative and to preempt competition.

With respect to the governance variables, we find that acquiring firms have higher option pay ratios (option pay plus option value dividend by cash pay), lower inside director ratios, and lower blockholder ownerships. Higher levels of option pay allow the management to take the extra risks involved in the corporate acquisition activity. It appears that inside directors are more conservative with respect to an acquisition decision. Possibly they are unsure about the changes within the organization following a successful acquisition deal. It is not uncommon to see a major change in the management team after a significant acquisition by a firm (Martin \& McConnell, 1991). A significant level of blockholder ownership in a firm's ownership structure acts as a governance control mechanism, whereby the blockholders with significant ownership watch the

\footnotetext{
${ }^{13}$ We further investigated the effect of relative size on the long-term operating performance. Results show that deals with higher relative sizes have better long-term operating performances.
} 
management actions more closely. Absence of any significant level of blockholder ownership gives more power and opportunity to the management team to make an acquisition decision. As expected, we also find support for the conjecture that the CEO hubris levels are significantly higher for the acquiring firms (Roll, 1986). We use CEO excess pay as a proxy for CEO hubris. As explained in Appendix L, CEO excess pay considers an integrated perspective of governance related weaknesses in a firm that leads to CEO hubris. None of the earlier studies have used any integrated measure to investigate the effect of CEO hubris on a firm's M\&A decision-making process.

Further, the results from analyzing differentiating characteristics shed light on M\&A motives and highlight at least two reasons behind an acquisition decision. First, we find strong support for an "empire building" motive behind M\&A. Our results indicate that firms with higher levels of cash reserves and CEO hubris are more likely to be acquirers. In other words, firms with more CEO discretion and excess resources tend to grow in size through acquisition. Second, we find that high-tech firms make more acquisitions that may have strategic implications. These firms are more likely to make an acquisition in order to stay innovative and to preempt competition.

Last but not the least, since the study investigates the short-term and long-term performance of the acquiring firms using the same dataset, we gain some unique and integrated perspectives on M\&A activities. For example, our results show that there are significant and positive cumulative abnormal returns around the announcement date. However, the market corrects its overreaction within 15 days and there are no long-term 
abnormal stock returns in the next 3-year period. Further, we find a consistent and integrated view of the relative size, market reaction, and long-term operating performance of acquiring firms. We find that the market reacts more positively to the larger relative size deals as recognition of their economic significance; this is reflected in higher and significantly positive long-term operating performances for the same category acquiring firms.

The remainder of this thesis is organized as follows. In the next chapter, the existing literature that is dominated by U.S. studies is reviewed to provide further context for this thesis. Chapter 3 presents the hypotheses and the sample and discusses relevant methodologies. Chapter 4, 5, 6, and 7 describe the empirical results pertaining to the short-term performance, long-term stock return performance, long-term operating performance, and acquiring firms' differentiating characteristics respectively. Chapter 8 presents the summary and conclusions. Finally, Chapter 9 outlines the major contributions of the thesis, its limitations and provides recommendations for future research. 


\section{CHAPTER 2: LITERATURE REVIEW}

The conventional research domain for M\&A issues includes the following: (i) short-term price performance of the shares of the target and the bidder and related factors influencing the performance, (ii) long-term performance of bidding firms, (iii) characteristics of target firms and bidding firms, (iv) motives of takeover; (v) adoption of anti-takeover measures and relevant impact, and (vi) industry shock and its impact on M\&A activity (see Appendix B for a summary). This study focuses on the first three areas of the literature and the relevant issues, namely, short term performance, long-term performance, and characteristics of bidding firms. Accordingly, the purpose of this chapter is to discuss the relevant literature on M\&A and to identify the different factors affecting the short- and long-term performance of an acquiring firm, and the differentiating characteristics of an acquiring firm. In the remainder of the chapter, sections 2.1 and 2.2 discuss the short and long-term performance issues of bidding firms and relevant empirical evidence. Section 2.3 presents the possible characteristics of a bidding firm that separate it from a non-bidding firm. As short- and long-term performance issues have a number of commonalities, these issues are presented together. 


\subsection{Performance of Bidding Firms: Short and Long-Term Perspective}

\subsubsection{Background}

\section{Short-Term Performance}

Over the last decades, there has been a considerable amount of research investigating the short-term gains or losses pertaining to takeover activities. Although there are many parties involved in takeover activity, empirical studies have focused mainly on the gains and losses of two primary parties involved in a takeover transaction: the buyer and the seller of the target company. Empirical evidence shows that the bidders' shareholders earn, on average, a zero abnormal return at the acquisition's announcement, but there is considerable variation in these results (Andrade et al., 2001; Bruner, 2003; Fuller et al., 2002). Summary results of the relevant studies are presented in Appendix C - Part 1. Table C. 1 presents the studies with negative abnormal returns to acquirers and Table C. 2 presents the studies with positive or zero abnormal returns to the acquirers.

The variation in short-term returns to bidding firms' shareholders is puzzling and researchers have been unable to explain successfully much of this variation (Fuller et al., 2002). Prior studies have identified a number of difficulties in estimating bidders' returns (Eckbo et al., 1990; Fuller et al., 2002; Grinblatt \& Titman 2002; Heitala et al., 2000). First, if the target's relative size is small, it will not cause any significant impact on the bidder's returns. Second, abnormal returns present only the surprise component of the acquisition. If the acquirer's motive is already known in the market from its past act, the 
stock price reaction would only refer to the perceived deviation of the announced deal from the anticipated one. Third, when it takes a longer time to conclude a takeover process, the uncertainty of the event is increased. Thus, it would be difficult to isolate the market's perception of the bid. Fourth, the stock returns of the bidder may tell us more about how the market is reassessing the bidder's business than it does about the value of acquisition and it is difficult to isolate different implications.

Subsequently, a number of factors are analyzed in the literature to justify the nature of acquiring (bidding) firm's short-term performance. This issue will be discussed in the following section.

\section{Long-Term Performance}

While the majority of the existing empirical evidence focuses on the stock returns surrounding announcement dates, a smaller body of research has examined long-run post acquisition returns. A summary of relevant studies is presented in Appendix D. It can be seen that most of the long-term studies conclude that bidder firms experience significant negative abnormal returns over one to three years after the merger (Agrawal et al., 1992; Asquith, 1983; Andrade et al., 2001; Gregory 1997). However, as early as 1991, Franks et al. (1991) point out that such negative abnormal returns could have resulted from benchmark errors rather than systematic mispricing by investors. Loughrun and Vijh (1997) have given impetus to this debate again by using the BHAR technique for the first time in this area; they report significant negative long-run abnormal returns following an acquisition. In a recent study, Mitchell and Stafford (2000) show that after correcting for 
methodological errors and considering cross-sectional dependence, no significant abnormal returns are observed using BHAR methodology. Negative abnormal returns for the acquiring firms are also viewed quite critically by practitioners and academicians for the following compelling reasons:

First, neo-classical economic theory assumes that corporate management acts to maximize the shareholders' wealth (Limmack, 1991). Takeovers are seen as devices through which inefficient management teams may be replaced, and this will facilitate the redeployment of capital to more efficient users (Weston, 1970). It follows, therefore, that if management pursues policies of shareholder wealth maximization, then shareholders should not suffer wealth decreases as a result of their company acquiring other companies (Limmack, 1991).

Second, assuming that the announcement-period stock price reaction fully impounds the information effects of merger, most research on mergers examines returns surrounding announcement dates and over a very short period of time. This approach implicitly assumes that markets are efficient in immediately digesting the full impact of the acquisition in a very short time period (Agrawal et al., 1992; Andrade et al., 2001).

Both the reasons stated above reinforce the argument that acquiring firms should not show any systematic underperformance in the long run. Therefore, the long run underperformance by acquiring firms as reported in most of the relevant studies leaves us in a paradoxical situation. However, other researchers have argued that negative long run 
performance could be observed due to following reasons: (i) motives of merger could be flawed or misrepresented (Andrade et al., 2001); (ii) operating performance following acquisitions could have been deteriorated, and hence, acquiring firms show negative performance in the long run (Herman \& Lowenstein, 1988; Ravenscraft \& Scherer, 1987). However, the evidence of underperformance in terms of operating activities is not one-sided (Healy et. al., 1992); (iii) methodologies used in detecting long run abnormal returns could be flawed and are sensitive to using different types of approaches (Barber \& Lyon, 1997; Fama, 1998; Ikenberry et al., 1995; Kothari \& Warner, 1997; Kothari \& Warner, 2005; Lyon et al., 1999; Mitchell \& Stafford, 2000).

Irrespective of the sign of the acquiring firm's performance, in the literature a number of factors are analyzed to justify the nature of acquiring (bidding) firm's long run performance; these are discussed below.

\subsection{Factors Affecting the Acquiring Firms' Short and Long-Term Performance}

This section is organized into two parts. First, theories and conjectures are discussed for the relevant factors affecting the bidding firm's performance. Implications of these factors on short and long-term performance are discussed together because of commonality in the issues. Second, relevant empirical evidence is presented. 


\subsubsection{Theory/Conjectures}

\section{Merger or Tender offer}

Agrawal and Jeffe (2000) have argued that researchers should analyze mergers and tender offers separately as they could have different implications for bidding firm performance. Tender offers are different from mergers in that in the case of tender offers, acquiring firms bid for target shares in the open market. On the other hand, mergers occur through discussion between the management of the bidding firm and the target firm. In general, tender offers are hostile and are usually done through a cash offer (Rau and Vermaelen, 1998). Merger offers are usually friendly and are generally done through a share offer (Loughran \& Vijh, 1997; Martin \& McConnell, 1991).

Implications for short-term performance. There are competing arguments on how this difference in the type of the offer would affect short-term stock performance of bidding firms. The following two reasons have been put forward as explanations for a positive impact for tender offers. First, tender offers, in general, are hostile and more efficient managers are appointed for the acquired companies, which lead to wealth gains (Loughran \& Vijh, 1997; Martin \& McConnell, 1991). Second, as stated earlier, tender offers are generally done through a cash offer. The acquirer's managers are likely to choose stock payment when their stock is overvalued and cash payment when it is undervalued (Loughran \& Vijh, 1997; Myers \& Majluf, 1984). As a result, in the case of a tender offer, there is a possibility for short-term stock return gains for the bidding firm's shareholders. Opposite effects are expected for mergers. On the other hand, since tender 
offers are hostile in nature, bidding firms may be required to pay an extra premium to the target firm's shareholders and a tender offer may attract multiple bidders. This would reduce the returns for the bidding firm's shareholders. Therefore, it is not very clear what would be the impact on short-term performance due to a merger or tender offer.

Implications for long-term performance. As discussed earlier, we expect that the market would react to the deal around the announcement date and the stock price will be adjusted accordingly in the short-run. As a result, there should not be any systematic underperformance (or over performance) by the acquiring firm in the long run.

\section{Type of Target Organization (Public or Private)}

It has been pointed out that bidders acquire targets for a better price when they buy a nonpublic firm as compared to a public firm, resulting in a better return for the acquiring firms' shareholders in the former case. The following reasons are cited to support this observation.

a. Liquidity impact and limited competition. Private firms and subsidiaries cannot be bought and sold as easily as publicly traded firms. This lack of liquidity makes these investments less attractive and hence offers are generally less for private firms. This gives a better return to bidding firm's shareholders (Fuller et al., 2002).

b. Monitoring hypothesis. Firms acquiring privately held targets through common stock exchanges tend to create outside blockholders because the targets are owned by a small group of shareholders (Chang, 1998). The creation of outside blockholders can serve as 
an effective monitor of management and, in turn, can increase bidder value (Chang, 1998; Fuller et al., 2002; Shleifer \& Vishny, 1986).

c. Investors' Portfolio Preference. Hansen and Lott (1996) hypothesize that since investors are diversified, the goal of the manager of a firm is not to maximize shareholder value, but to maximize the value of the shareholder's portfolio. Thus, when a public bidder acquires a public target, diversified shareholders will be indifferent to how the gains from the acquisitions are divided, assuming they own stock in both firms. Hence, there should not be any abnormal return for the bidding firm's shareholders if a public firm is acquired.

Implications for short-term and long-term performance. For the reasons stated above, it is expected that the acquisition of a private company would lead to positive short-term abnormal returns. However, there should not be any systematic long-term abnormal return as we expect the market to react around the announcement date.

\section{Related (non-conglomerate) and Unrelated (conglomerate) Acquisitions}

A merger is defined as non-conglomerate if an acquirer and its target are in the same industry. It is generally claimed that conglomerate mergers are less likely to succeed because managers of acquiring firms are not familiar with the target industry or they waste free cash flow on bad acquisitions (Agrawal et al., 1992; Jensen 1986). Also, shareholders do not prefer that the bidding company managers diversify their operations as shareholders can rebalance and diversify their portfolio by themselves by investing in 
different types of assets. Therefore, diversification through acquisition is likely to be viewed negatively in the market.

Implications for short-term and long-term performance. Based on the reasons stated above, it is expected that the acquisition of a related company would lead to positive short-term abnormal returns. However, there should not be any systematic long-term abnormal return as we expect the market to react around the announcement date.

\section{Methods of Payment}

Myers and Majluf (1984) argue that a bidder firm will use stock as the medium of exchange if the board believes that its own shares are overvalued. Alternatively, if the firm is convinced with its current valuation, they may offer cash in order to send a positive signal to the market (Eckbo et al., 1990; Fishman, 1989; Fuller et al., 2002). Also, if the bidder is uncertain about the target's value, the bidder may not want to offer cash since the target will only accept a cash offer greater than its true value and the bidder will have overpaid (Fuller et al., 2002).

Implications for short-term and long-term performance. Because the usage of stock indicates an overvaluation of the bidding firm and because a cash payment indicates a certainty of target valuation, it is expected that the choice of a cash payment would lead to a better short-term performance. However, there should not be any systematic longterm abnormal return as we expect the market to react around the announcement date. 


\section{Growth and Value Firms}

Rau and Vermaelen (1998) argue that in companies with high market-to-book ratios (termed "glamour" firms), managers are more likely to overestimate their own abilities to manage an acquisition, i.e., they will be infected by hubris (Roll, 1986). Indeed, glamour firms are firms with high past stock returns and high past growth in cash flow and earnings (Lakonishok et al., 1994); this should presumably strengthen the management's belief in its own actions. Moreover, other shareholders in these firms, including the board of directors and large shareholders, are more likely to trust the management's decision and approve its acquisition plans (Rau \& Vermaelen, 1998). On the other hand, in the companies with low market-to-book ratios ("value" firms), managers, directors, and large shareholders may be more prudent before approving a major transaction that could determine the survival of the company. In contrast to the above argument, Lang et al. (1989) argue that well-managed firms are rewarded positively in the market, which subsequently leads to a higher market-to-book value ratio. For such firms, a positive reaction in the market is expected following an acquisition announcement

Implications for short-term and long-term performance. As the value firms make more prudent decisions in selecting a target company, it is expected that there will be a positive market reaction (short-term performance) if a value firm makes the acquisition. However, there should not be any systematic long-term abnormal return, as we expect the market to react around the announcement date. 


\section{Governance Characteristics (Board Independence and Ownership Structure)}

In recent years, corporate governance issues have attracted considerable attention of both practitioners and academicians. It has been argued that governance mechanisms can contribute towards better firm performance - although we do not see any definitive consensus in empirical results presented in different studies. Commonly cited governance mechanisms that may influence abnormal returns of the bidding firms around the announcement period include board independence (more outsider directors, and separation of CEO and board chairperson position), managerial ownership, and blockholder ownership. Possible impacts can be summarized as follows: (i) board independence and increased level of blockholder ownership would lead to greater monitoring of the bidding firm's management which would lead to better acquisition decisions, and (ii) increased level of managerial ownership would align management's interest with that of shareholders' (Fama \& Jensen, 1983; Subrahmanyam, Rangan, \& Rossenstein, 1997). This would lead to better managerial decisions. However, some studies have argued and showed that such relationship might not be monotonic (Morck et al., 1988).

Implications for short-term and long-term performance. As board independence, the presence of blockholder ownership and increased managerial ownership would lead to better monitoring and alignment of managerial interest, there is likely to be a better shortterm reaction. However, there should not be any systematic long-term abnormal return as we expect the market to react around the announcement date. 


\section{Takeover Premium}

In order to take over a firm, bidders generally need to pay a premium to the target firm's shareholders. A takeover premium is often justified with the potential value creation from the acquisition deal due to a synergistic effect. However, as pointed out by Roll (1986), there is always a possibility of a margin of error in valuing an acquisition deal and consequently, bidders might end up paying an excessive premium to target shareholders. Because of the information asymmetry, it would be difficult for the shareholders to know about the extent of mispricing or overpricing. It is likely that shareholders would interpret an acquisition of a target with a high premium as good news as management is highly interested in acquiring the target firm. Alternatively, if the acquiring firm pays an excessive premium to the target shareholders, it will be viewed negatively by the market.

Implications for short-term and long-term performance of bidding firm shareholders. If the percentage takeover premium is higher, it is expected that the short-term market reaction will be positive. However, there should not be any systematic long-term abnormal return as we expect the market to react around the announcement date.

\section{Long-run Operating Performance}

In addition to studies that investigated performance based on the stock market parameters, there have been a few studies that have investigated the impact on long-term operating performance for acquiring companies following the acquisition event. If a merger truly creates value for shareholders, the gains should eventually show up in the

firm's cash flows (Andrade et al., 2001). Moreover, because of synergistic effect, 
operating performance should improve for the combined firm following an acquisition. On the other hand, if the acquisition is made because of CEO hubris or if the motive of the acquisition is flawed, bidding (or combined) firms would experience negative operating performance in the long run.

Earlier studies have shown that results of long-run operating studies depend on methodological choices. For example, Healy et al. (1992) use industry mean adjusted cash flow to total assets in the pre- and post-event period to investigate the improvement on operating performance of an acquiring firm. They compare the mean and median of industry mean adjusted operating performance for the pre- and post-event period in their study. Ghosh (2001) argues that from an economic standpoint, the methodology employed by Healy et al. (1992) is flawed for at least two reasons. First, Ghosh argues that larger firms generally make acquisitions within an industry segment and they are likely to be more profitable compared to the industry average benchmark just because of the size effect (Fama and French, 1995). Second, acquiring firms generally make acquisitions following a period of above industry average performance. Consequently, Ghosh (2001) recommends the use of matching firm benchmarks in the spirit of Barber and Lyon's (1996) arguments.

Implications for short-term and long-term performance. Long-run operating results would not have any direct impact on the short-term stock market performance of bidding firms. However, if we see a positive relationship between short-term returns and long-run operating performance, it can be argued that an expectation of a future economic 
performance by the bidding firm following an acquisition is truly reflected in the shortterm market price reaction around the announcement date. From the long run perspective, it is expected that positive long-run operating performance would lead to a positive signal in the market and, hence, it should be reflected in positive long-run stock return performance. In other words, long-term operating performance and long-term stock return performance should be positively correlated.

It should be noted that the relative size of the target company could influence the magnitude of short-term and long-term performances of the bidding firm. This issue is briefly discussed below.

\section{Relative Size}

The acquisition of a relatively large target is likely to be a more important economic event for the acquirer than is the acquisition of a relatively small target (Eckbo et al., 1990). Higher relative size could bring in more synergy (positive effect). Alternatively, it could be more difficult to manage a larger target company (negative effect). A number of studies have considered this aspect. For example, Loderer and Martin (1992) have excluded all acquisitions that are smaller than ten percent of acquirer size whereas Moeller et al. (2003) have used a cut-off point of one percent. Some other studies have used absolute value of the bid for an acquisition to be considered in the analysis. For example, Malatesta (1983) considers 10 million USD or greater deals and Gregory (1997) considers 10 million $\mathfrak{£}$ or greater deals. 
Agrawal et al. (1992) examine the issue more scientifically. They rank all the mergers by relative size and form quintile portfolios. Next, they calculate the long-run abnormal returns of each portfolio individually but fail to detect any monotonic relationship. Moeller et al. (2003) report a positive effect whereas Fuller et al. (2002) find that the effect of relative size is negative for public targets and positive for private targets. Overall, they report a positive relationship between the relative deal size and the acquiring firm's short-term abnormal returns. However, none of these studies have discussed the implications of relative size on the acquiring firm's long-term performance.

Based on the arguments discussed above, a summary of the expected impact of the above factors on bidding firm's short-term performance has been presented in Figure 2.1 below. As discussed above, we do not expect any systematic long-term abnormal return due to any of the factors discussed above other than the acquiring firm's operating performance in the post event period. Empirical evidence on short-term and long-term performance of acquiring firms has been presented in Table 2.1. 
Figure 2.1 Expected Sign of Various Factors' Influence on a Bidding Firm's Shortterm Abnormal Performance

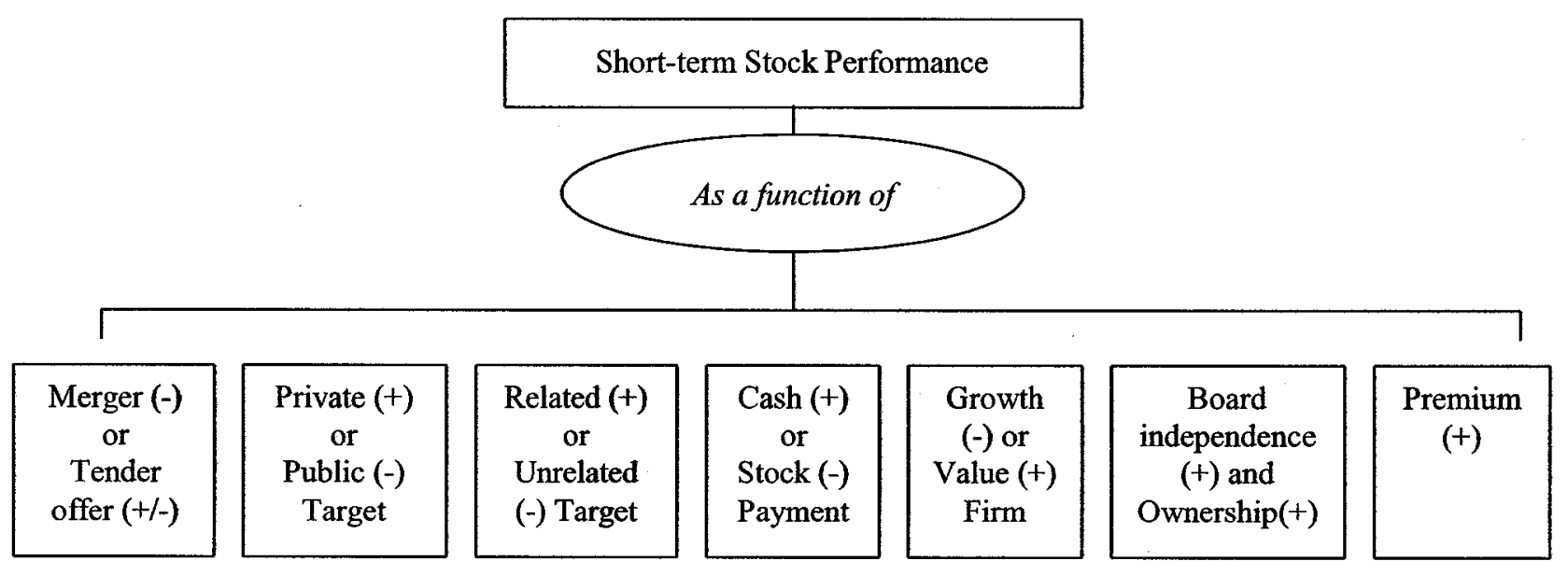

\subsubsection{Empirical Evidence for Acquiring Firms' Short- and Long-term Performance}

Key empirical evidence for bidding firm performance with respect to the factors

discussed above is summarized in Table 2.1.

Table 2.1 Factors Affecting Bidding Firms' Return: Summary of Empirical Evidence

\begin{tabular}{|l|l|l|}
\hline \multicolumn{1}{|c|}{ Factor } & \multicolumn{1}{|c|}{ Short-Term Performance } & \multicolumn{1}{|c|}{ Long-Term Performance } \\
\hline Tender offer & $\begin{array}{l}\text { Empirical evidence is inconclusive in this } \\
\text { context. Jensen and Ruback (1983) show } \\
\text { positive abnormal returns for bidding and } \\
\text { target firms for both tender offer and merger. } \\
\text { Lang, Stultz, and Walking (1989) and Jarrell } \\
\text { and Poulsen (1989) report positive significant } \\
\text { returns to bidder in tender offers. Other } \\
\text { studies report insignificant returns to bidders } \\
\text { in tender offers (Ghosh \& Lee, 2000; Travlos, } \\
\text { Loughran \& Vijh, 1997; Rau \& Vermaelen, 1998). }\end{array}$ & $\begin{array}{l}\text { Generally, long-term stock return } \\
\text { 1987; Walker, 2000). }\end{array}$ \\
\hline $\begin{array}{l}\text { Private or Public } \\
\text { Target }\end{array}$ & $\begin{array}{l}\text { Generally higher return is reported for private } \\
\text { target acquisition (Hansen \& Lott 1996; } \\
\text { Moeller et al., 2003; Yuce \& Ng, 2005). } \\
\text { Chang (1998) examines bidder returns to } \\
\text { firms acquiring 281 privately held targets (131 } \\
\text { cash offers and 150 stock offers) and } \\
\text { compares them to bidder returns for 255 } \\
\text { public targets (101 cash offers and 154 stock } \\
\text { offers). Chang finds no abnormal return for } \\
\text { bidders in the case of cash offers. However, }\end{array}$ & \\
\hline
\end{tabular}




\begin{tabular}{|c|c|c|}
\hline Factor & Short-Term Performance & Long-Term Performance \\
\hline & $\begin{array}{l}\text { for stock offers, Chang reports a } 2.64 \% \\
\text { abnormal return for privately held targets and } \\
-2.46 \% \text { abnormal return for publicly held } \\
\text { targets. }\end{array}$ & \\
\hline $\begin{array}{l}\text { Related or } \\
\text { Unrelated } \\
\text { Acquisition }\end{array}$ & $\begin{array}{l}\text { Empirical evidence generally supports the } \\
\text { hypothesis that related acquisitions would } \\
\text { result in better stock returns for the bidding } \\
\text { firms' shareholders (Maquieira et al., 1998; } \\
\text { Moeller et al., 2003; Morck et al., 1990). } \\
\text { However, Chang's (1998), and Fuller et al.'s } \\
\text { (2002) results show that there is no significant } \\
\text { difference in the bidder's abnormal return due } \\
\text { to this factor. However, in a Canadian context, } \\
\text { Eckbo and Thorburn (2000) report opposite } \\
\text { results. }\end{array}$ & $\begin{array}{l}\text { Agrawal et al. (1992) examine this issue by } \\
\text { calculating the cumulative average abnormal return } \\
\text { of acquiring companies for conglomerate and non- } \\
\text { conglomerate acquisitions after adjusting for both } \\
\text { firm size and beta. In contrast to popular belief, } \\
\text { they find that the underperformance of acquirers is } \\
\text { worse in non-conglomerate mergers than in } \\
\text { conglomerate mergers. Similarly, with Canadian } \\
\text { data, Andre et al. (2004) report long-term } \\
\text { underperformance for related acquisitions but not } \\
\text { for unrelated acquisitions. }\end{array}$ \\
\hline $\begin{array}{l}\text { Methods of } \\
\text { Payment }\end{array}$ & $\begin{array}{l}\text { Fuller et al. (2002), Moeller et al. (2003), } \\
\text { Fishman (1989), and Martin (1996) have } \\
\text { found that bidder firms earn higher abnormal } \\
\text { returns when they use cash as opposed to } \\
\text { stock for acquiring a target. However, Eckbo } \\
\text { (2000) does not find any significant difference } \\
\text { in a Canadian context. }\end{array}$ & $\begin{array}{l}\text { Loughran and Vijh (1997), Dodds and Quek } \\
\text { (1985) and Franks et al. (1991) have found that the } \\
\text { long-run abnormal return is higher for bidding } \\
\text { firms' shareholders in the case of cash offers in } \\
\text { comparison with stock offers. }\end{array}$ \\
\hline $\begin{array}{l}\text { Growth or Value } \\
\text { Firms }\end{array}$ & $\begin{array}{l}\text { Lang et al. (1989) and Servaes (1991) describe } \\
\text { positive effects for value firms and Dong et al. } \\
\text { describe negative effect for value firms. In } \\
\text { contrast, Moeller et al. (2003) show no } \\
\text { significant effect. Further, Rau and Vermaelen } \\
\text { (1998) show that glamour bidders in mergers } \\
\text { pay more frequently with stock than do value } \\
\text { acquirers. }\end{array}$ & $\begin{array}{l}\text { Rau and Vermaelen (1998) find that value } \\
\text { acquirers earn statistically significant positive } \\
\text { abnormal returns of } 8 \% \text { in mergers and } 16 \% \text { in } \\
\text { tender offers, while glamour acquirers earn } \\
\text { statistically significant abnormal returns of } 17 \% \text { in } \\
\text { mergers and insignificant abnormal returns of } 4 \% \\
\text { in tender offers. }\end{array}$ \\
\hline $\begin{array}{l}\text { Governance } \\
\text { Characteristics }\end{array}$ & $\begin{array}{l}\text { Byrd and Hickman (1992) report that bidding } \\
\text { firms with a majority of independent directors } \\
\text { enjoy higher announcement-date abnormal } \\
\text { returns than others. Cotter et al. (1997) report } \\
\text { similar results for target firm shareholders. }\end{array}$ & No direct study found. \\
\hline $\begin{array}{l}\text { Takeover } \\
\text { Premium }\end{array}$ & No direct study found & No direct study found \\
\hline $\begin{array}{l}\text { Operating } \\
\text { Performance }\end{array}$ & Not relevant & $\begin{array}{l}\text { There is mixed evidence in the literature. Some of } \\
\text { the earlier studies report negative long-term } \\
\text { operating performance (Herman \& Lowenstein, } \\
\text { 1988; Ravenscraft \& Scherer, 1987). Others have } \\
\text { reported an improvement in long-term operating } \\
\text { performance (Andrade et al., 2001; Healy et al., } \\
\text { 1992; Jog \& Riding, 1988). However, Ghosh } \\
\text { (2001) finds no evidence for long term operating } \\
\text { performance improvement. }\end{array}$ \\
\hline
\end{tabular}

In line with the main focus of this study, only issues related to short and long term performance of bidding firms are discussed above. However, there have been numerous 
studies on the performance of target firms' shareholders, which support the argument that shareholders of target firms enjoy positive returns around the takeover announcement date. Though this issue is not investigated in this research study since the results are a natural consequence of the target firms receiving a premium, a short discussion is presented in Appendix C (Part 2) simply to have a holistic perspective of performance issues.

\subsection{Firm Specific Characteristics and Governance Characteristics of Bidding Firms}

\subsubsection{Motivation}

As stated earlier, besides investigating the short- and long-term issues of the bidding firm's shareholders, the other important research question of this study is to identify what characteristics of an acquiring firm differentiate it from a non-acquiring firm. The motivation for investigating this issue is described below.

First, although there have been a few studies that investigate the characteristics of a target firm $^{14}$, there is virtually no comprehensive study that examines the characteristics of an acquiring firm ${ }^{15}$.

\footnotetext{
${ }^{14}$ A summary of the studies that investigate the characteristics of a target firm is presented in Appendix E.

${ }^{15}$ Only Harford (1999) has looked into this issue of bidder characteristics by considering 487 bids over a period of 1977 to 1993. Though Harford's main concern was to investigate the impact of cash richness on the probability of a firm being bidder, other factors such as average abnormal return, sales growth, noncash working capital, leverage, market to book ratio, price-to-earnings ratio, firm size and ownership variables were considered in the model. However, Harford does not offer any theoretical justification for the consideration of various variables in the model other than the impact of cash richness.
} 
Second, as presented in the earlier section, the characteristics of bidder firms may have implications for the short-term and long-term stock return performance of their shareholders. Consequently, knowing the characteristics of a bidding firm would give some valuable information to the stockholders in terms of their expected stock return following an acquisition announcement (Bae, Kang, \& Kim, 2002).

Third, a revelation of the differing governance characteristics (if any) between the bidding and non-bidding firms would tell us about the role of governance mechanisms (such as board independence and ownership structure) in making an acquisition decision.

Fourth, an identification of the bidding firms' characteristics would also shed some light upon the motives underlying the acquisition activities (Powell, 1997). For example, we would know whether a growth firm or a technologically oriented firm would be more involved in takeover activities or not.

Accordingly, this study attempts to identify the characteristics of an acquiring firm that separate it from a non-acquiring firm. The following section presents justifications for the consideration of various firm-specific and governance-related variables that may represent the characteristics of a bidding firm.

Probable characteristics of a bidding firm are divided into two groups: (i) firm specific characteristics - that include cash reserves, leverage, market-to-book value ratio, past 
performance, firm $\operatorname{size}^{16}$, sales growth, and R\&D intensity; and (ii) governance characteristics - that include managerial ownership, blockholder ownership, CEO pay, board size, and board independence. These are discussed in the next section.

\subsubsection{Firm Specific Characteristics}

\section{Cash reserves}

Cash reserves can provide a valuable source of funds for investment opportunities. Firms often accumulate much more cash than they require. Jensen (1986) argues that a firm's agency problem can get compounded with the presence of large free cash flows. Excessive cash reserves insulate managers from being monitored by the external market forces and give them the opportunity to invest in value-decreasing investment decisions such as non-productive acquisitions (Harford, 1999). Therefore, it is expected that cashrich companies would make more acquisitions in comparison with cash-depleted companies.

\section{Leverage}

An increase in leverage increases the likelihood of financial distress, which in turn increases the cost of inefficient decisions to managers. Debt service forces managers to distribute cash rather than invest in value-decreasing investments (Byrd et al., 1998; Jensen, 1988). Moreover, higher debt levels would induce more monitoring by the debt providers (creditors). The creditors would try to ensure that management services the debt in a timely fashion which, in turn, would reduce the agency cost of free cash flow by

\footnotetext{
${ }^{16}$ Unless otherwise stated, market value has beed used as a proxy for firm size.
} 
reducing the discretionary cash flow spending by managers (Jensen, 1988). Thus, it can be argued that with the increase in leverage level, the probability of making an acquisition would decrease.

\section{Market-to-Book Value Ratio}

This issue has been discussed in an earlier section. Considering the management's extra "confidence" in a growth company, it can be argued that the firms with high market-tobook ratios are more likely to make an acquisition than are the firms with low market-tobook ratios.

\section{Past Performance}

Positive performance in previous years would give more confidence to the management about their operations. Hence, it is expected that past positive performance would increase the probability of a firm to become an acquirer. Harford's (1999) results show that the probability for a firm to become an acquirer increases with positive past performance. Healy et al. (1992) have shown that bidder firms had a positive performance (on average) up to five years prior to the acquisition year. Palepu (1986) and later studies (for example, Harford, 1999) have used two different measures to represent past performance. First, they incorporated the excess stock return of a firm by using the market model and daily stock return data and they calculated the average value over a period of four years. Second, they used the firm's return on equity as the measure of past performance. 


\section{Firm Size, Sales Growth and R\&D Intensity}

Other firm-specific factors also bear further investigation. Firm size can play an important role in the event of an acquisition. Generally, larger firms would have appropriate resources to make an acquisition. However, the relationship is not expected to be monotonic. If a firm becomes too large, it may not be interested in making further acquisition as, it would be increasingly difficult to manage a larger firm, and the acquisition of a new firm might not add any net value to existing operations. Alternatively, positive sales growth over the past years might prompt a firm to make further acquisitions in order to support its future growth. Finally, rapid technological developments, increasing developmental costs and shorter life cycles of technological products would prompt firms in technological sectors to acquire new technology through appropriate means (Narula \& Hagendoom, 1999; Narula \& Sadowaski, 2002). One way to achieve this is to acquire other innovative companies. Therefore, we may expect that firms with greater technology intensity ${ }^{17}$ would acquire more companies to avoid developmental costs, to preempt competition, and to remain competitive in a particular sector.

Based on the arguments presented above, a summary of the bidding firms' firm- specific characteristics that separate them from non-bidding firms is presented in Figure 2.2.

\footnotetext{
${ }^{17} \mathrm{R} \& \mathrm{D}$ intensity, expressed as the total R\&D expenditure to total firm sales, is a very widely used measure for measuring technological intensity in a firm that is free of inflation effects (Lee \& O'Neill, 2003).
} 
Figure 2.2 Firm Specific Characteristics of a Bidding Firm

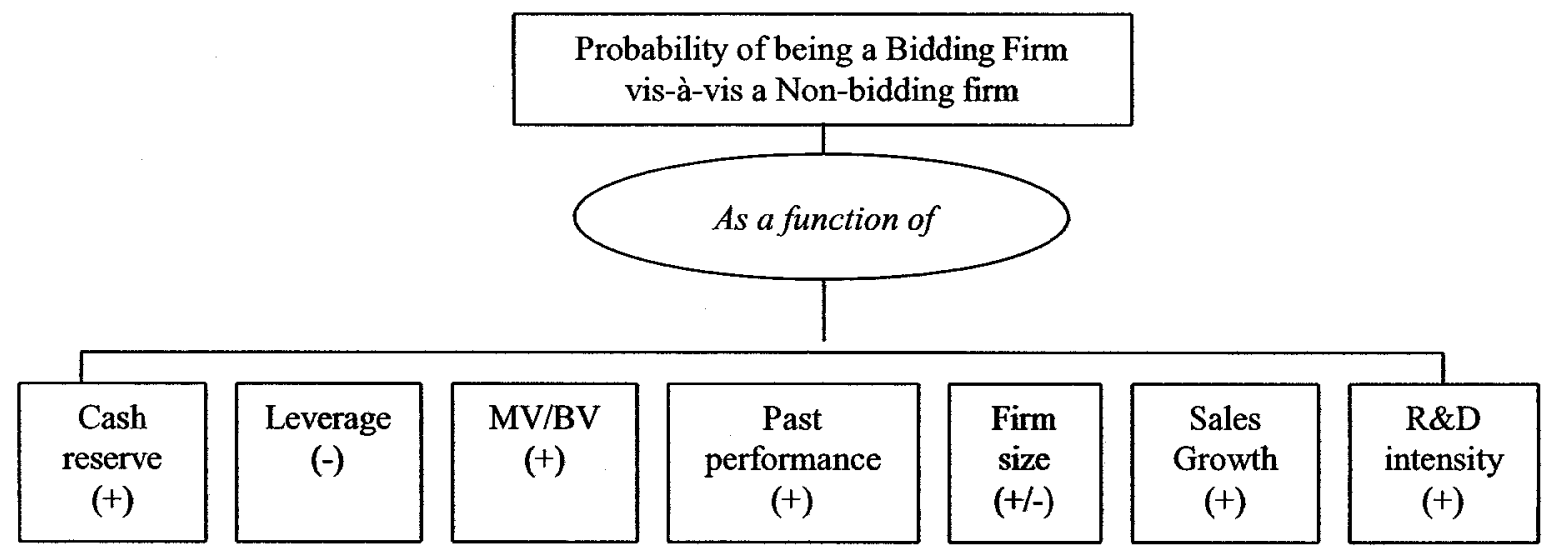

\subsubsection{Governance Characteristics}

\section{Managerial Ownership}

Earlier studies such as Berle and Means (1932) and Jensen and Meckling (1976) point out that the level of managerial ownership is a potential source of agency problem. If the managerial ownership is too low, their interest will not be aligned with that of other shareholders. As a result, management may make decisions that are not in the best interests of shareholders. On the other hand, if management has considerable ownership in a firm, they may be more careful in making a decision that is more favorable for the existing shareholders. Empirical evidence (see Appendix C - Table C.1 and Table C.2) demonstrates that there is a considerable variation (positive, zero, and negative) in the stock return of bidding firms' shareholders following a takeover announcement. This variation suggests that acquisition activities are quite risky for the bidding company's shareholders. Considering this view, managers who have higher levels of ownership may 
be less inclined to make an acquisition decision, as a larger amount of the managers' own wealth is tied up with company performance.

\section{Blockholder Ownership}

Shliefer and Vishny (1986) predict that, all else being equal, the presence of a large blockholder will have a positive effect on the market value of the firm. The potential takeover threat that large blockholders can exert works as an effective device for monitoring management. Others argue that because of higher levels of ownership, blockholders are likely to take an active part in monitoring and hence make positive contributions to a firm's performance (Bhagat \& Jefferis, 2002). As a corollary, it can be argued that the presence of large blockholders would inhibit management from making any value-decreasing acquisitions. Another reason exists that would reinforce such an argument. If a firm is willing to make an acquisition for diversification purpose, it will not be appealing to the blockholders or the institutional investors. Generally, blockholder or institutional investors manage their own portfolios and hence can diversify on their own by investing in preferred types of industries and firms. In addition, the acquisition can be viewed as a risky venture for a bidding company and as a result, institutional investors may prefer to avoid such risk by voting against an acquisition attempt made by management. Therefore, it is expected that firms with higher levels of blockholder ownership are likely to make fewer acquisitions. 


\section{CEO Pay}

CEO pay has generally two components - cash and stock options. Some studies have investigated the impact of an acquisition on the CEO cash pay. Bliss and Rosen (2001) show that CEO compensation typically increases after bank mergers even if the acquirer's stock price declines. Using a sample of 327 large M\&A deals between 1993 and 1999, Grinstein and Hribar (2004) find that approximately $39 \%$ of the acquiring firms reward their CEOs with cash bonuses for the successful completion of a merger or acquisition deal, whereas Coreiro and Veliyath (2003) show that the level of firm diversification increases the cash component of CEO compensation as diversification increases CEO responsibility. However, none of the studies reviewed have researched the reverse effect - that is the impact of CEO cash compensation on a firm's acquisition attempt. There is no compelling theory on how CEO cash pay would affect an acquisition decision.

Stock options are introduced to reduce agency problem by aligning management interests with that of shareholders. It is argued that stock options are more useful than cash payments when monitoring the executives becomes more difficult in the presence of significant growth opportunities for the firms. This perspective is equally applicable for an acquisition possibility. As possible investment decisions are primarily known to CEOs and top management only, information asymmetry may arise from such opportunities that make an evaluation of the managers' investment choices more difficult. Accordingly, firms with greater investment opportunities are likely to rely on incentive compensation, including stock options (Bizjak et al., 1993; Bryan et al., 2000; Mehran \& Tracy, 2001; 
Smith \& Watts, 1992; Yermack, 1995). For such firms, stock option awards would protect risk-averse CEOs from downside risk and simultaneously provide a high upside potential, which would motivate CEOs to undertake value generating risky projects. Therefore, it can be argued that an increase in CEO stock option pay would increase the probability of a firm to make an acquisition ${ }^{18}$.

\section{CEO Hubris}

Roll (1988) presents the theory of CEO hubris ${ }^{19}$. The hubris hypothesis posits that acquisitions are motivated by managers' mistakes in the absence of any synergistic gain. Berkovitch and Narayanan (1993) find support for this argument in their study by analyzing target, acquirer, and total gain from a deal. Hayward and Hambrick (1997) have also identified CEO hubris as one of the major motives behind an acquisition and have shown that $\mathrm{CEO}$ hubris leads to higher acquisition premiums. Therefore, it is expected that a CEO of an acquiring firm will have more hubris compared to a CEO of a non-acquiring firm.

\section{Board Size}

As Wu (2000) points out, there is no comprehensive theory relating the board size and its decision making process. However, Jensen (1993) and Lipton and Lorsch (1992) have suggested that large boards can be less effective than small boards. When boards become

\footnotetext{
${ }^{18}$ Impact of CEO cash pay and option pay can be investigated simultaneously by using the ratio of CEO option pay to CEO cash pay. If the ratio is low, a CEO may be less interested in making an acquisition decision and vice versa. This is consistent with the arguments presented with respect to CEO cash pay and option pay and subsequent acquisition decisions.

${ }^{19}$ Hayward and Hambrick (1997) states, "there is no reliable instrument to measure CEO hubris directly" (p. 108). They recommend using past firm performance and board characteristics along with the media praise for CEO as an indirect measure of CEO hubris.
} 
too big, agency problems (such as director free-riding) increase with the board and the board becomes more symbolic and less a part of the management process (Hermalin \& Weisbach, 2003; Jensen, 1993). Wu (2000) has structured similar arguments as follows: (i) small boards of directors facilitate better communication among directors, more effective coordination of the directors' expertise, and speed up action when there is a problem; and (ii) a limited number of board members prevent a board from developing into a bureaucracy, from dividing into cliques, and from encouraging passivity at meetings. As a corollary, it can be argued that a smaller board would approve an acquisition only if it is beneficial for the firm. It is not likely to approve any valuedecreasing deal, whereas a large board would not be able to restrain management from making any acquisition decision irrespective of the deal's value creation scenario. Therefore, it is expected that firms with larger board sizes would make more acquisition decisions.

\section{Board Independence}

As mentioned in the previous section, board independence (a majority of independent directors and a unrelated board chair) is likely to result in better decisions from the shareholders' perspective ${ }^{20}$. It is expected that an independent board would be less likely to agree to an acquisition decision, as there is considerable risk associated with such move.

\footnotetext{
${ }^{20}$ However, we do not see any conclusive evidence from existing literature on the effectiveness of board independence (Bhagat and Black, 2002; Mak and Li, 2001).
} 
Based on the arguments presented above, a summary of bidding firms' governance characteristics that separate them from non-bidding firms is presented in Figure 2.3.

\section{Figure 2.3 Governance Characteristics of a Bidding Firm}

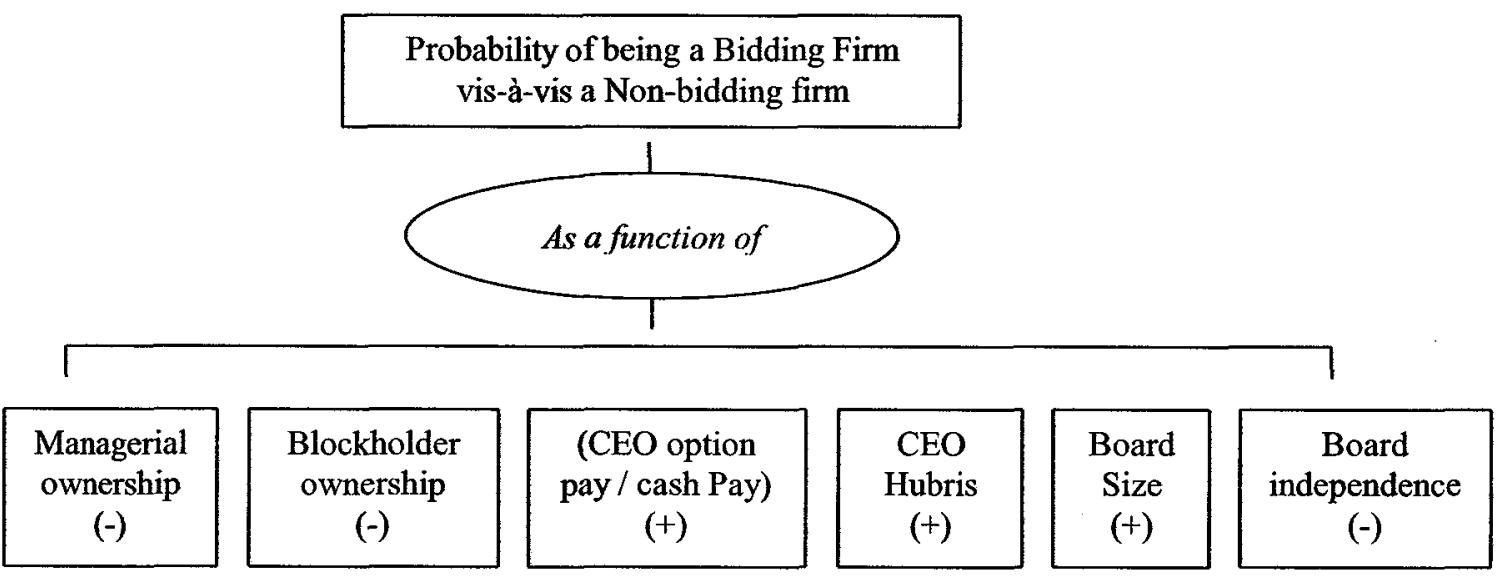

In addition to firm-specific and governance characteristics, some studies have stressed industry specific issues ${ }^{21}$ that influence a firm's acquisition decisions. Since this is more of a macroeconomic phenomenon rather than a firm-specific issue, it is not investigated in this study.

\subsubsection{Empirical Evidence}

As stated earlier, studies dedicated to identifying bidder characteristics are scarce. Harford (1999) investigates the impact of cash richness on the probability of a firm being a bidder, along with other factors such as average abnormal return, sales growth, non-

${ }^{21}$ Gort (1969) argues that mergers are caused by valuation differentials among market participants which are triggered by economic shocks such as changes in technology, industry structure, and regulatory environment. Some of the recent studies (Andrade et al., 2001; Mitchell \& Mulherin, 1996) also support this phenomenon. 
cash working capital, leverage, market to book ratio, price-to-earnings ratio, firm size, and ownership variables. The results show that the likelihood of attempting an acquisition increases with cash richness of a firm. Harford's (1999) results also indicate that the probability of being an acquirer increases with past average abnormal return, sales growth, non-cash working capital, and firm size, yet decreases with the price-to-earnings ratio. However, once the model incorporates ownership data in order to identify the extent of agency problem, most of the relationships observed earlier disappear ${ }^{22}$. The main result of Harford's study is also consistent with Opler et al.'s (1999) work, in that cash reserves and subsequent acquisition spending are positively correlated. Grinstein and Hribar (2004) have investigated the impact of board independence on firm's acquisition decision-making probability. They find that a firm with CEO duality and more insider directors is more likely to make large acquisition deals.

\footnotetext{
${ }^{22}$ It should be noted that sample size decreases dramatically while incorporating ownership data in Harford's (1999) study in which ownership data was gathered only for 1990-1993 (2,857 firm years in total).
} 
CHAPTER 3: RESEARCH METHODOLOGY

\subsection{Hypotheses}

\subsubsection{Short-term and Long-term Performance of Acquiring Firms}

Based on the discussion presented in Chapter 2, the following hypotheses for the acquirer's short-term and long-term performance are evaluated in the study (Table 3.1).

\section{Table 3.1 Hypotheses for Short and Long-Term Performance for Acquiring Firms}

\begin{tabular}{|l|l|l|}
\hline \multicolumn{1}{|c|}{ Issue } & \multicolumn{1}{|c|}{ Short Term Performance } & \multicolumn{1}{|c|}{ Long Term Performance } \\
\hline $\begin{array}{l}\text { Overall } \\
\text { Performance }\end{array}$ & $\begin{array}{l}\text { Hypothesis ST1: Overall, there is a positive } \\
\text { and significant cumulative abnormal return } \\
\text { around the announcement date for the } \\
\text { bidding firms. }\end{array}$ & $\begin{array}{l}\text { Hypothesis LT1: On an aggregate basis, there is } \\
\text { no significant long-term under-performance in } \\
\text { terms of stock return for the acquiring firms. }\end{array}$ \\
\hline $\begin{array}{l}\text { Tender or } \\
\text { Merger offer }\end{array}$ & $\begin{array}{l}\text { Hypothesis ST2: Short-term performance } \\
\text { for acquiring firms is better for tender offers } \\
\text { than for mergers. }\end{array}$ & $\begin{array}{l}\text { Hypothesis LT2: There will be no significant } \\
\text { long-term abnormal performance for the } \\
\text { acquiring firm. }\end{array}$ \\
\hline $\begin{array}{l}\text { Private or } \\
\text { Public Target }\end{array}$ & $\begin{array}{l}\text { Hypothesis ST3: Short-term performance } \\
\text { for acquiring firms is better for the } \\
\text { acquisition of private targets than for public } \\
\text { targets. }\end{array}$ & $\begin{array}{l}\text { Hypothesis LT3: There will be no significant } \\
\text { long-term abnormal performance for the } \\
\text { acquiring firm. }\end{array}$ \\
\hline $\begin{array}{l}\text { Related or } \\
\text { unrelated } \\
\text { Acquisition }\end{array}$ & $\begin{array}{l}\text { Hypothesis ST4: Short-term performance } \\
\text { for acquiring firms is better for related } \\
\text { acquisitions than for unrelated acquisitions } \\
\text { (diversification). }\end{array}$ & $\begin{array}{l}\text { Hypothesis LT4: There will be no significant } \\
\text { long-term abnormal performance for the } \\
\text { acquiring firm. }\end{array}$ \\
\hline $\begin{array}{l}\text { Methods of } \\
\text { Payment }\end{array}$ & $\begin{array}{l}\text { Hypothesis ST5: Short-term performance } \\
\text { for acquiring firms is better for cash offers } \\
\text { than for stock transactions. }\end{array}$ & $\begin{array}{l}\text { Hypothesis LT5: There will be no significant } \\
\text { long-term abnormal performance for the } \\
\text { acquiring firm. }\end{array}$ \\
\hline $\begin{array}{l}\text { Growth or } \\
\text { Value Firms }\end{array}$ & $\begin{array}{l}\text { Hypothesis ST6: Short-term performance } \\
\text { for acquiring firms is better for value firms } \\
\text { (low market-to-book value) than for growth } \\
\text { firms (high market-to-book value) }\end{array}$ & $\begin{array}{l}\text { Hypothesis LT6: There will be no significant } \\
\text { long-term abnormal performance for the } \\
\text { acquiring firm. }\end{array}$ \\
\hline $\begin{array}{l}\text { Board } \\
\text { independence }\end{array}$ & $\begin{array}{l}\text { Hypothesis ST7: Short-term performance } \\
\text { is better for bidding firms with independent } \\
\text { boards. }\end{array}$ & $\begin{array}{l}\text { Hypothesis LT7: There will be no significant } \\
\text { long-term abnormal performance for the } \\
\text { acquiring firm. }\end{array}$ \\
\hline
\end{tabular}




\begin{tabular}{|l|l|l|}
\hline \multicolumn{1}{|c|}{ Issue } & \multicolumn{1}{|c|}{ Short Term Performance } & \multicolumn{1}{|c|}{ Long Term Performance } \\
\hline $\begin{array}{l}\text { Managerial } \\
\text { Ownership }\end{array}$ & $\begin{array}{l}\text { Hypothesis ST8: Short-term performance } \\
\text { is better for bidding firms with higher } \\
\text { managerial ownership. }\end{array}$ & $\begin{array}{l}\text { Hypothesis LT8: There will be no significant } \\
\text { long-term abnormal performance for the } \\
\text { acquiring firm. }\end{array}$ \\
\hline Relative Size & $\begin{array}{l}\text { Hypothesis ST9: Acquiring firms perform } \\
\text { better with smaller M\&A deals } \\
\text { (announcement value) than with bigger } \\
\text { deals in the short run around the } \\
\text { announcement date. }\end{array}$ & $\begin{array}{l}\text { Hypothesis LT9: There will be no significant } \\
\text { long-term abnormal performance for the } \\
\text { acquiring firm. }\end{array}$ \\
\hline $\begin{array}{l}\text { Takeover } \\
\text { Premium }\end{array}$ & $\begin{array}{l}\text { Hypothesis ST10: Short-term abnormal } \\
\text { return will be higher for high target } \\
\text { premium deals. }\end{array}$ & $\begin{array}{l}\text { Hypothesis LT10: There will be no significant } \\
\text { long-term abnormal performance for the } \\
\text { acquiring firm. }\end{array}$ \\
\hline $\begin{array}{l}\text { Operating } \\
\text { Performance }\end{array}$ & \multicolumn{2}{l}{$\begin{array}{l}\text { Hypothesis LT11: There is no significant long } \\
\text { run underperformance with regards to operating } \\
\text { performance for the combined firms. }\end{array}$} \\
\hline
\end{tabular}

\subsubsection{Differentiating Characteristics of Acquiring Firms}

Based on the discussion presented in Chapter 2, the following hypothesis pertaining to the characteristics of acquiring and non-acquiring firms is evaluated in this study.

\section{Hypothesis: CH-1 (Difference between bidding and non-bidding firms)}

There will be a significant difference between bidding firms and non-bidding firms with respect to firm-specific and governance characteristics ${ }^{23}$.

\section{Probability of being an acquirer \\ $=F n$ (firm specific variables) + Fn (governance variables) \\ =Fn (Cash Reserve, Leverage, Past Performance, Market to Book Value, Firm Size, Sales Growth, R\&D intensity) + Fn (Managerial Ownership, Board Size, CEO duality, inside/outside board member ratio, CEO pay ratio (option/cash), CEO hubris)}

\footnotetext{
23 Firm Specific Characteristics Include: Cash Reserve, Leverage, Past Performance, Market to Book Value, Firm Size, Sales Growth, and R\&D intensity. Governance Characteristics Include: Managerial Ownership, Board Size, CEO duality, inside/outside board member ratio, CEO pay ratio (option/cash), CEO hubris.
} 


\subsection{Sample}

This study considered all Canadian M\&A deals that occurred between 1993 and 2002 and involved a TSX-listed bidding company. We obtained our dataset from the SDC Thomson Financial Database. Our data met the following criteria: (i) the deals were completed, (ii) the acquiring firm was not from the financial industry, (iii) acquiring firms with multiple acquisitions during 1993-02 period were considered, (iv) deals with all sizes of transaction value were considered ${ }^{24}$. Stock return data was collected from the CFMRC (Canadian Financial Market Research Center) database. Accounting information was collected from the StockGuide database. Information related to governance variables was manually collected from firms' annual reports and management information circulars.

Descriptive statistics of the sample are presented in Table 3.2 and Table 3.3. Some of the important observations are as follows: (i) in line with the overall Canadian merger and acquisitions (M\&A) activities (Appendix I), we see in our sample that there is an increase in M\&A deals between 1996 and 2000. Thereafter, we observe a declining trend. (ii) Most of the deals are in minerals, manufacturing, and service industry. (iii) There are significantly higher levels of (a) merger offers than tender offers, (b) pure cash transactions than pure equity financed deals, and (c) growth acquiring firms ${ }^{25}$ than value acquiring firms.

\footnotetext{
${ }^{24}$ Out of 1300 events considered in the study, only 88 cases have transaction values less than $\$ 1$ million CDN.

${ }^{25}$ We define a growth-acquiring firm as the acquiring firm with price-to-book value of more than 1 in the preceding year of an acquisition.
} 
Table 3.2 Yearly and Sectoral Distribution of Canadian Acquirers Listed on Toronto Stock Exchange

The sample size is 1300 acquisition events over 1993-2002 period by Canadian acquirers listed on the TSX. The sample includes multiple acquirers. 'Multiple acquirers' refers to the acquiring firms that acquire more than one target in a calendar year. 'Single acquirers' acquire only one target in any calendar year.

Panel A. Number of acquisitions over 1993-2002 and corresponding transaction value

\begin{tabular}{|c|c|c|c|c|c|c|}
\hline & $\begin{array}{l}\text { \# of } \\
\text { Transactions }\end{array}$ & $\begin{array}{l}\text { \# of } \\
\text { Acquirer }\end{array}$ & $\begin{array}{l}\text { \# of Single } \\
\text { Acquirer }\end{array}$ & $\begin{array}{l}\text { \# of } \\
\text { Multiple } \\
\text { Acquirer }\end{array}$ & $\begin{array}{l}\text { Total } \\
\text { Transaction } \\
\text { Value (in \$ } \\
\text { mil. CDN) }\end{array}$ & $\begin{array}{l}\text { Avg. } \\
\text { Transaction } \\
\text { Value (in \$ } \\
\text { mil. CDN) }\end{array}$ \\
\hline 1993 & 93 & 70 & 57 & 13 & 4919.0 & 52.9 \\
\hline 1994 & 105 & 82 & 67 & 15 & 9021.2 & 85.9 \\
\hline 1995 & 107 & 78 & 63 & 15 & 7757.6 & 72.5 \\
\hline 1996 & 139 & 100 & 73 & 27 & 7366.3 & 53.0 \\
\hline 1997 & 159 & 127 & 101 & 26 & 11293.7 & 71.0 \\
\hline 1998 & 160 & 109 & 81 & 28 & 40006.9 & 250.0 \\
\hline 1999 & 135 & 105 & 84 & 21 & 30467.8 & 225.7 \\
\hline 2000 & 150 & 107 & 85 & 22 & 54739.8 & 364.9 \\
\hline 2001 & 134 & 100 & 75 & 25 & 18440.2 & 137.6 \\
\hline 2002 & 118 & 90 & 71 & 19 & 18922.5 & 160.4 \\
\hline Total & 1300 & 968 & 757 & 211 & 202934.9 & 156.1 \\
\hline
\end{tabular}

Panel B. Transactions by Primary SIC Code ${ }^{26}$

\begin{tabular}{lllllll}
\hline \multicolumn{1}{c}{ SIC } & $\begin{array}{l}\text { \# of } \\
\text { Transactions }\end{array}$ & $\begin{array}{l}\text { \# of } \\
\text { Acquirer }\end{array}$ & $\begin{array}{l}\text { \# of single } \\
\text { Acquirer }\end{array}$ & $\begin{array}{l}\text { \# of } \\
\text { Multiple } \\
\text { Acquirer }\end{array}$ & $\begin{array}{l}\text { Total } \\
\text { Transaction } \\
\text { Value (in \$ } \\
\text { mil CDN) }\end{array}$ & $\begin{array}{l}\text { Avg. } \\
\text { Transaction } \\
\text { Value (in \$ } \\
\text { mil. CDN) }\end{array}$ \\
\hline 10 Minerals & 394 & 303 & 242 & 61 & 31723.3 & 80.5 \\
20-39 Manufacturing & 325 & 239 & 184 & 55 & 89352.3 & 274.9 \\
40 Communications & 154 & 101 & 71 & 30 & 53195.2 & 345.4 \\
50 Trade & 42 & 35 & 30 & 5 & 1730.2 & 41.2 \\
70-89 Services & 385 & 290 & 230 & 60 & 26933.9 & 70.0 \\
Total & 1300 & 968 & 757 & 211 & 202934.9 & 156.1 \\
\hline
\end{tabular}

\footnotetext{
${ }^{26}$ We follow the industry classification adopted by Andre et al. (2004) in consolidating various sub-groups.
} 


\section{Table 3.3 Descriptive Statistics of Firm-Specific Variables, Governance Variables and Deal-Specific Variables for Acquiring Firms}

The sample consists of 968 annual observations for acquiring firms between 1993 and 2002 for the firm specific variables and 638 for the governance variables between 1997 and 2002; the data for previous years is not available. For acquiring firms, only one event is considered in case of multiple acquisitions by the firm in any year.

\section{Panel A. Firm specific variables}

Total asset is the sum of all fixed and current assets of the acquiring firm as presented in the balance sheet for the year prior to the year in which acquisition is made. $R \& D$ intensity is the ratio of $R \& D$ expenditure to sales revenue in the prior year. Leverage is the ratio of (current liability + long term debt) to total asset in the prior year. Price to book value is the ratio of the firm's market value to book value in the prior year. Average sales growth is the average of an individual year's sales growth over five years prior to the year of acquisition. Cash flow to total asset is the ratio of the firm's cash flow to total asset in the prior year. Return on equity is the ratio of net income to net worth of the firm in the prior year. 'Relative size' is the ratio of transaction value and market value of the acquiring firm's equity.

\begin{tabular}{llll}
\hline & Mean & Median & Std. Dev \\
\hline Total Asset (TASST1) in 000\$ & 1182965.3 & 175579.0 & 2747989.5 \\
R\&D Intensity (RNDInty1) (ratio) & 0.05 & 0.00 & 0.18 \\
Leverage (Lever1) (ratio) & 0.47 & 0.48 & 0.21 \\
Price to book value (PrBV1) (ratio) & 2.44 & 1.90 & 1.99 \\
Average sales growth (AvgSgrth) (average ratio) & 0.73 & 0.25 & 1.91 \\
Return on equity (Requty1) (\%) & 4.52 & 8.99 & 21.04 \\
Cash flow to total asset (CFTasst1) (ratio) & 0.08 & 0.09 & 0.11 \\
Relative Size (RelSise1) (ratio) & 0.189 & 0.070 & 0.287 \\
\hline
\end{tabular}




\section{Panel B. Governance variables}

CEO cash pay is the sum of salary and annual cash bonus. CEO total pay is the sum of salary, cash bonus, and realized stock option pay in that year. The compensation data were obtained from management information circulars. Pay ratio is the ratio of CEO's stock option value (CEO's aggregate realized option value in a year + CEO's unexercised option value) to cash pay.

'Chair is related' is a dummy variable equal to " 1 " if the chair is related to management or the board, " 0 " otherwise. For example, if CEO is also chair of the board, the dummy variable is equal to "1". Percentage of inside directors is the ratio of related directors to total board size. Board size is the number of directors on the board. CEO ownership is the percentage of outstanding shares owned by the CEO. Three categories are created for CEO ownership, namely, for less than $5 \%, 5-25 \%$, and more than $25 \%$. Blockholder ownership is the percentage of outstanding shares owned by individuals or institutions other than the directors. If the blockholder ownership is less than $10 \%$, the input value for this variable is " 0 ". Three categories are created for blockholder ownership, namely, for less than $10 \%, 10-25 \%$, and more than $25 \%$. Director ownership is the percentage of outstanding shares owned by all directors (including the CEO) of the firm. Three categories are created for director ownership, namely, for less than $5 \%, 5-25 \%$, and more than $25 \%$.

\begin{tabular}{llll}
\hline & Mean & Median & Std. Dev \\
\hline CEO cash pay (cashpay) in \$ & 561890.66 & 390000.00 & 516219.89 \\
CEO total pay (totalpay) in \$ & 829599.50 & 458380.00 & 1010913.76 \\
Pay ratio (PayRat1) (ratio) & 3.95 & 0.91 & 7.43 \\
Percentage of inside director (Pindir) (ratio) & 0.32 & 0.29 & 0.16 \\
Chair is related (ChrRel) & 0.63 & 1.00 & 0.48 \\
Board size (Bdsize) & 8.20 & 7.00 & 2.84 \\
CEO ownership (CEOown) (\%) & 10.85 & 1.78 & 18.92 \\
CEO ownership (<5\%) (CEOOwn1) \% & 63.00 & 100.00 & 48.00 \\
CEO ownership (5-25\%) (CEOOwn2) \% & 22.00 & 000.00 & 41.00 \\
CEO ownership (>25\%) (CEOOwn3) \% & 15.00 & 000.00 & 35.00 \\
Blockholder ownership (Blkown) \% & 9.39 & 0.00 & 19.19 \\
Blockholder ownership (<10\%) (BlkOwn1) \% & 73.00 & 100.00 & 45.00 \\
Blockholder ownership (10-25\%) (BlkOwn2) \% & 13.00 & 000.00 & 34.00 \\
Blockholder ownership (>25\%) (BlkOwn3) \% & 14.00 & 000.00 & 35.00 \\
Director ownership (Dirown) \% & 17.37 & 10.40 & 19.37 \\
Director ownership (<5\%) (DirOwn1) \% & 38.00 & 000.00 & 49.00 \\
Director ownership (5-25\%) (DirOwn2) \% & 35.00 & 000.00 & 48.00 \\
Director ownership (>25\%) (DirOwn3) \% & 27.00 & 000.00 & 45.00 \\
\hline
\end{tabular}

Panel C. Transactions by Deal Characteristics

"Deal size" is the total transaction value in million Canadian dollars. "Tender or merger" is a dummy variable. If the acquisition is completed through tender offer, the value is " 1 " and " 0 " otherwise. "Target type" is a categorical variable outlining the nature of target firm. Three categories are created: (i) public target (pubprv1), (ii) private target (pubprv2), and (iii) other (subsidiaries, joint ventures etc.) (pubprv3). "Related/unrelated acquisition" is a dummy variable. For related acquisition, the value is " 1 " and " 0 " otherwise. It is determined based on the SIC code of acquiring firm and target firm. Two versions of this dummy variable are created based on: (i) 4 digit SIC code, and (ii) 2 digit SIC code. "Payment type" or "Methods of payment" is a categorical variable outlining the nature of transaction payment mode. Three categories are created: (i) cash payment (paytype1), (ii) stock payment (paytype2), and (iii) mixed or other (paytype3). "Cross border target (CrsBd2_3)" is a dummy variable. The value is "1" if the target is from outside Canada or the US and " 0 " otherwise. "Growth or value" is a dummy variable. The value is " 1 " if the acquiring firm's price to book value ratio is greater than 1 and " 0 " otherwise. "Chair is related" is a dummy variable and is equal to " 1 " if the chair is related to management or the board, " 0 " otherwise. For example, if the CEO is also chair of the board, the dummy variable is equal to " 1 ". 'Board independence' is a dummy variable. The value is " 1 " if majority of the board members are unrelated and "0" otherwise. 
"Director ownership" is the percentage of outstanding shares owned by all directors (including the CEO) of the firm. Three categories are created for director ownership: for less than 5\%, 5-25\%, and more than $25 \%$. "Blockholder ownership" is the percentage of outstanding shares owned by individuals or institutions other than the directors. If the blockholder ownership is less than $10 \%$, the input value for this variable is " 0 ". Three categories are created for blockholder ownership: for less than 10\%, 10-25\%, and more than $25 \%$. "Relative size" is the ratio of transaction value and market value of the acquiring firm's equity. Total number of events is 1300 for each deal characteristics category.

\begin{tabular}{|c|c|c|c|}
\hline & & Number & Percentage \\
\hline Deal Size & Less than $10 \mathrm{~m}$ & 535 & $41.2 \%$ \\
\hline \multirow[t]{2}{*}{ (Transaction Value) } & 10 to $100 \mathrm{~m}$ & 499 & $38.4 \%$ \\
\hline & More than $100 \mathrm{~m}$ & 266 & $20.5 \%$ \\
\hline \multirow[t]{2}{*}{ Tender or Merger } & Tender & 142 & $10.9 \%$ \\
\hline & Merger & 1158 & $89.1 \%$ \\
\hline \multirow[t]{3}{*}{ Target Type } & Public & 400 & $30.8 \%$ \\
\hline & Private & 476 & $36.6 \%$ \\
\hline & Other (Sub., JV) & 424 & $32.6 \%$ \\
\hline \multirow{3}{*}{$\begin{array}{l}\text { Related/ Unrelated Target } \\
\text { (based on } 4 \text { digit SIC) }\end{array}$} & Related & 527 & $40.5 \%$ \\
\hline & Unrelated & 772 & $59.4 \%$ \\
\hline & Info. not available & 1 & $0.1 \%$ \\
\hline \multirow[t]{3}{*}{ Methods of Payment } & Cash & 764 & $58.8 \%$ \\
\hline & Stock & 184 & $14.2 \%$ \\
\hline & Other/Mixed & 352 & $27.1 \%$ \\
\hline \multirow[t]{3}{*}{ Growth or Value Acquirers } & Growth & 1057 & $81.3 \%$ \\
\hline & Value & 164 & $12.6 \%$ \\
\hline & Info. not available & 79 & $6.1 \%$ \\
\hline \multirow[t]{3}{*}{ Chair is Related } & Related & 459 & $35.3 \%$ \\
\hline & Unrelated & 286 & $22.0 \%$ \\
\hline & Info. not available & 555 & $42.7 \%$ \\
\hline \multirow[t]{3}{*}{ Board Independence } & Independent & 611 & $47.0 \%$ \\
\hline & Dependent & 126 & $9.7 \%$ \\
\hline & Info. not available & 563 & $43.3 \%$ \\
\hline \multirow[t]{4}{*}{ Director Ownership } & Less than $5 \%$ & 346 & $26.6 \%$ \\
\hline & 5 to $25 \%$ & 268 & $20.6 \%$ \\
\hline & More than $25 \%$ & 230 & $17.7 \%$ \\
\hline & Info. not available & 456 & $35.1 \%$ \\
\hline \multirow[t]{4}{*}{ Blockholder Ownership } & Less than $10 \%$ & 606 & $46.6 \%$ \\
\hline & 10 to $25 \%$ & 102 & $7.8 \%$ \\
\hline & More than $25 \%$ & 136 & $10.5 \%$ \\
\hline & Info. not available & 456 & $35.1 \%$ \\
\hline \multirow[t]{3}{*}{ Cross Border Targets } & Canada & 755 & $58.1 \%$ \\
\hline & USA & 316 & $24.3 \%$ \\
\hline & Other & 229 & $17.6 \%$ \\
\hline \multirow[t]{4}{*}{ Relative Size } & Less than $5 \%$ & 496 & $38.2 \%$ \\
\hline & 5 to $25 \%$ & 398 & $30.6 \%$ \\
\hline & More than $25 \%$ & 259 & $19.9 \%$ \\
\hline & Info. not available & 147 & $11.3 \%$ \\
\hline
\end{tabular}




\subsection{Methodology}

To ensure the robustness of the results, different methodologies were used to test the hypotheses pertaining to short-term performance, long-term performance, and differentiating characteristics of acquiring firms.

\subsubsection{Short-term Performance Issues}

Hypothesis testing was done in two stages: univariate analysis and multivariate analysis.

For testing hypotheses ST-1 to ST-8, we followed Linn and McConnell's (1983) event study procedure and calculated daily abnormal return (AR), and cumulative abnormal return (CAR) around the announcement date and reported the corresponding ' $z$ ' statistics. We corrected for first order autocorrelation to the ' $z$ ' statistics as proposed by Heinkel and Kraus (1988). The significance of AR and CAR value was tested using critical ' $z$ ' values. Detail procedures of the event study along with various issues have been outlined in Appendix F. In order to check the robustness of the results, we repeated the analysis (i) for all cases and excluding multiple acquirers separately, and (ii) by using the market model and the market-adjusted model separately. Hypothesis ST-9 and ST-10 were investigated through multiple regression analysis. For the multivariate analysis, the following regression analysis was performed ${ }^{27}$ :

\footnotetext{
${ }^{27}$ Multicollinearity is tested for each independent variable by checking the variance inflation factor (VIF) and the structure of lower eigenvalue factors reported in SPSS collinearity diagnostics tables.
} 
CAR $(0,+2)=f n$ (tender or merger offer, form of payment, related or unrelated target, public or private, chair is related or not, outside/inside director ratio, price to book value, managerial ownership, percentage takeover premium, relative size)

We used dummy variables to control for the "year" and "industry" effect in the multiple regression analysis.

\subsubsection{Long-term Stock Return Performance Issues}

For long-term stock return performance analysis, we investigated the 3-year stock return performance in the post-event period starting from the effective date of a completed deal.

Like the short-term performance analysis, hypothesis testing was done in two stages: univariate analysis and multivariate analysis. As stated earlier, there has been a vigorous debate on the proper methodological choice to detect long-term abnormal performance in the post-acquisition period. In order to check the robustness of the results, we used both the event-time approach (buy and hold abnormal return - BHAR), and the calendar-time approach (Fama-French three factor regression) to evaluate long-term performance. A summary of different methodologies and their merits/demerits have been presented systematically in Appendix G. In the case of BHAR analysis, we made adjustments for skewness in return data (Lyon et al., 1999) and "cross-sectional dependence" among concurrent events (Mitchell \& Stafford, 2000) in the $t$-statistics to account for relevant 
biases. We used six different benchmarks in the BHAR analysis ${ }^{28}$. In the case of the Fama-French three factor ${ }^{29}$ regression, we checked the alpha value and its significance.

For testing hypotheses LT-1 to LT-8, initially we performed univariate analyses. We calculated BHAR and Fama-French alpha separately for each variable and evaluated the corresponding $t$-statistics. Hypothesis LT-9 and LT-10 were investigated through multiple regression analyses.

For the multivariate analysis, the following regression analysis was performed ${ }^{30}$ :

$B H A R=f n$ (tender or merger offer, form of payment, related or unrelated target, public or private, chair is related or not, outside/inside director ratio, price to book value, managerial ownership, percentage takeover premium, relative size)

We used a dummy variable to control for "year" and "industry" effects in the multiple regression analysis.

\subsubsection{Evaluating Long-term Operating Performance}

In this study we used both industry-adjusted operating performance (Healy et al., 1992) and matching firm adjusted operating performance (Ghosh, 2001) approaches. In order to select a matching firm, we followed a two-stage procedure. First, we identified all the TSX firms that have not made any acquisition in the period of 1992 to 2003 . Second, we performed an OLS regression considering all acquiring firms and matching firms. We

\footnotetext{
${ }^{28}$ See Appendix $M$ for the description of each benchmark.

${ }^{29}$ We obtained Fama-French three factor data from the BARRA website (for TSX companies).

${ }^{30}$ Multicollinearity was tested for each independent variable by checking the variance inflation factor (VIF) and the structure of lower eigenvalue factors reported in SPSS collinearity diagnostics tables.
} 
regressed the firms' return on equity on firm size and market-to-book value variables (Loughran \& Vijh, 1997). Subsequently, matching firms were selected based on the nearest propensity score obtained by using the coefficients of firm size and price-to-book value factors. As suggested by Healy et al., (1992), we used both the "intercept" approach and the "mean comparison" approach to detect the difference in pre- and post-acquisition operating performance.

\subsubsection{Differentiating Characteristics of Acquiring Firms}

Following Palepu et al. (1986), we used binary logistic regression ${ }^{31}$ to detect the differentiating characteristics between acquiring and non-acquiring firms ${ }^{32}$.

$$
\text { Basic form of a logit model: } \log \left(\frac{\pi}{1-\pi}\right)=\alpha+\beta x
$$

Where $\pi$ is the probability of a firm being an acquirer given the set of characteristics " $x$ "; $\beta$ is the set of coefficients for corresponding " $x$ " characteristics. Wald-statistics was used to find out the significance of the variables.

We can find the probability of the stock being selected as: $\pi=\frac{e^{(\alpha+\beta x)}}{1+e^{(\alpha+\beta x)}}$

In the binary logit model, the dependent variable is a dichotomous variable. The value is " 1 " if the firm in the sample has made an acquisition in the 1993-2002 period and "0" otherwise. For non-acquiring groups, we selected the firms that have not made any acquisitions between 1992 and 2003.

\footnotetext{
${ }^{31}$ Appendix $\mathrm{H}$ presents the detailed methodological issues involved in logistic regression.

${ }^{32}$ Multicollinearity is tested for each independent variable by checking variance inflation factor (VIF) and the structure of lower eigenvalue factors reported in SPSS collinearity diagnostics tables.
} 


\section{CHAPTER 4: RESULTS: SHORT-TERM ABNORMAL RETURN FOR ACQUIRING FIRMS}

In this chapter, we describe the results for short-term stock return performance around an acquisition announcement date. We first describe the results for all acquisition events between 1993 and 2002 using event time methodology. Subsequently, we present the results for the implications of various deal-specific and firm-specific factors on shortterm return performance.

\subsection{Short-term Performance for an Acquisition Event}

In this section, we present the short-term stock return performance for all acquiring firms around the announcement date ${ }^{33}$. As noted earlier, to check the robustness of the results we performed the analysis separately for (i) all acquiring events, and (ii) all acquiring events, but excluding the multiple acquisition events by a firm within the same calendar year. This allowed us to check the impact of non-overlapping events separately. Table 4.1 and 4.2 present the results for daily abnormal return and cumulative abnormal return respectively.

From Table 4.1, we find that there is a significant positive abnormal return around the announcement date ('day -2 ', 'day 0 ', 'day +1 ', and 'day +2 '). This means the market reacts positively on the announcement of an acquisition event. This also implies the market's initial confidence in the management decision, in general. Further, we find that

${ }^{33}$ Estimation window is -31 day to -120 day relative to the announcement date. 
subsequently the market corrects its overreaction, which is reflected in a negative abnormal return between day 3 and day 7 and again on day 10 and day 11 . Results are quite similar for (i) all acquiring events, and (ii) all acquiring events but excluding the multiple acquisition events by a firm within the same calendar year.

We found similar results (Table 4.2) for cumulative abnormal return (CAR). In order to check the impact of an acquisition announcement over different time periods, we used six different versions of CAR. We found that CARs are significantly positive for the $(-1,+1)$, $(-2,+2),(0,+2)$, and $(-5$, to +5$)$ periods for both categories (including and excluding multiple acquiring firms). We also found that as we increased the number of days in CAR analysis starting from the announcement date, results were less significant; for CAR $(0$, +15 ) it was not statistically significant anymore. We also performed non-parametric tests for both abnormal returns and cumulative abnormal returns. Results are reported in Table 4.1 and 4.2 respectively.

Overall, we found that the market reacts positively on an acquisition announcement event. However, the market corrects the overreaction in the short-run in the post event period. Within 15 days of the post announcement date, there is no indication of a positive reaction by the market to announcements. Results are robust for non-multiple and multiple acquirers in the same calendar year. 
Table 4.1 Short-run Daily Abnormal Return: Market Model $^{34}$

The sample size was 989 for all acquiring events and 534 for all acquiring events excluding multiple acquisitions by a firm in the same calendar year. " $A D$ " indicates the announcement date. We used the market model to determine the abnormal return and adjusted abnormal return. "AR" is the daily abnormal return based on the average difference in the return performance between the acquiring stock and the benchmark. The statistical significance of the abnormal return is examined by $Z$ statistics introduced by Lin and McConnell (1983). Standard deviation of AR used in the test accounts for the first order correlation effect (please refer to Appendix $F$ for details). In the case of the non-parametric test, the percentage positive indicates how many stocks experienced the positive abnormal returns. Corresponding binomial $t$ test values are reported with a cut-off value of 0.50 . CAR results are reported in decimals.

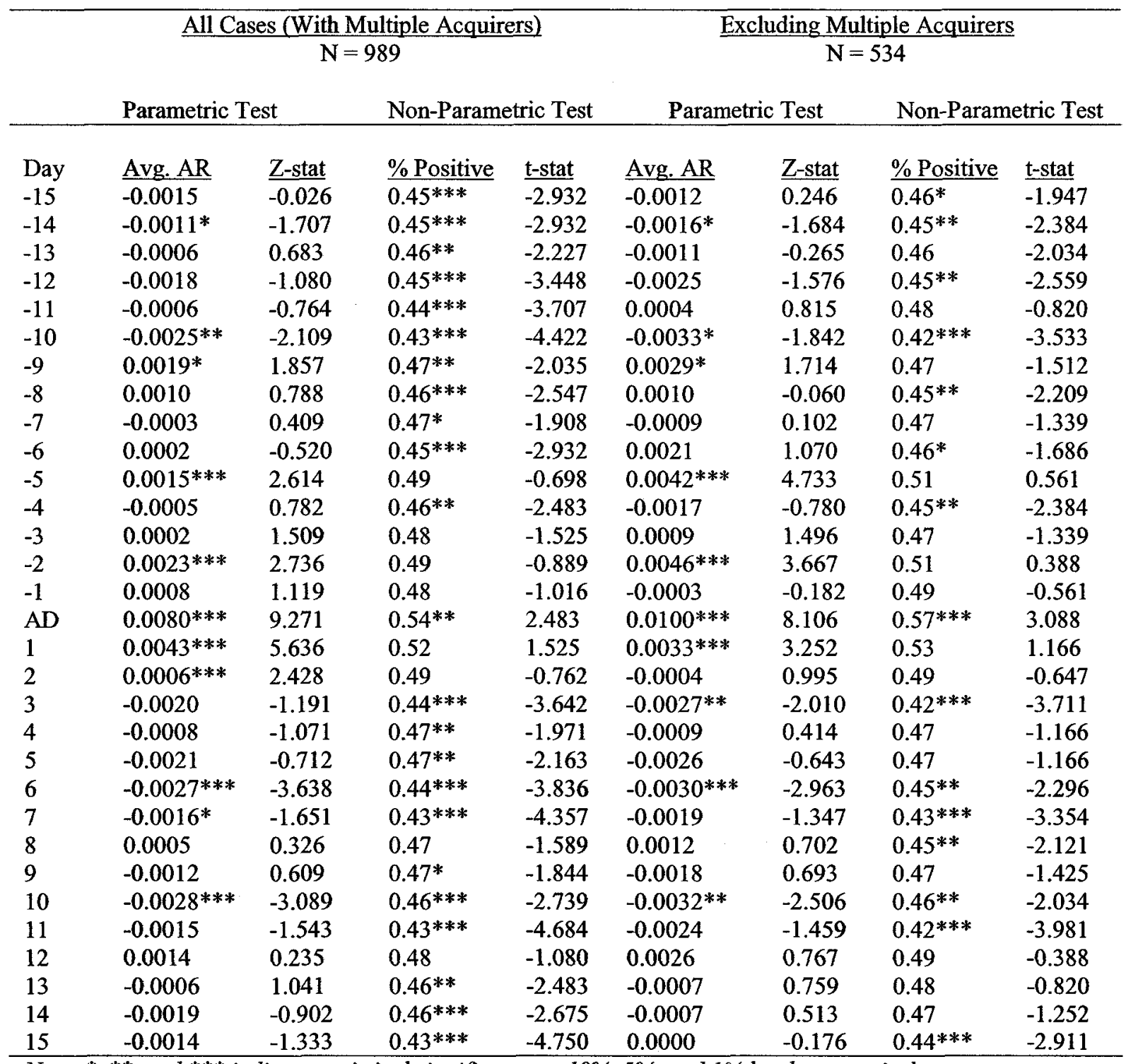

Note: *,**, and *** indicate statistical significance at $10 \%, 5 \%$, and $1 \%$ levels respectively.

\footnotetext{
${ }^{34}$ We obtain similar results by using market-adjusted model.
} 


\section{Table 4.2 Short-run Cumulative Abnormal Return: Market Model}

The sample size is 989 for all acquiring events and 534 for all acquiring events excluding multiple acquisitions by a firm in the same calendar year. We used the market model to determine the abnormal return and adjusted abnormal return. "CAR" is the average of the summation of the abnormal returns for each stock for a specific period. Six different versions of CAR were used in the analysis. The statistical significance of the abnormal return was examined by $Z$ statistics introduced by Lin and McConnell (1983). Standard deviation of AR used in the test accounts for the first order correlation effect (please refer to Appendix $F$ for details). In the case of the non-parametric test, the percentage positive indicates how many stocks experienced the positive cumulative abnormal returns. Corresponding binomial $t$ test values are reported with a cut-off value of 0.50 . CAR results are reported in decimals.

\begin{tabular}{|c|c|c|c|c|c|c|c|c|}
\hline & \multicolumn{4}{|c|}{$\frac{\text { All Cases (With Multiple Acquirers) }}{\mathrm{N}=989}$} & \multicolumn{4}{|c|}{$\frac{\text { Excluding Multiple Acquirers }}{\mathrm{N}=534}$} \\
\hline & \multicolumn{2}{|c|}{ Parametric Test } & \multicolumn{2}{|c|}{ Non-Parametric Test } & \multicolumn{2}{|c|}{ Parametric Test } & \multicolumn{2}{|c|}{ Non-Parametric Test } \\
\hline Period & Avg. CAR & $\underline{Z \text {-stat }}$ & \% Positive & $\underline{\text { t-stat }}$ & Avg. CAR & Z-stat & $\%$ Positive & t-stat \\
\hline$(-1,+1)$ & $0.013 * * *$ & 9.253 & $0.54 * * *$ & 2.647 & $0.013 * * *$ & 6.453 & $0.54 *$ & 1.909 \\
\hline$(-2,+2)$ & $0.016^{* * *}$ & 9.476 & $0.56^{* * *}$ & 3.680 & $0.017^{* * *}$ & 7.083 & $0.55^{* *}$ & 2.259 \\
\hline$(0,+2)$ & $0.013^{* * *}$ & 10.008 & $0.55^{* * *}$ & 3.291 & $0.013 * * *$ & 7.132 & $0.55 * *$ & 2.171 \\
\hline$(-5,+5)$ & $0.012^{* * *}$ & 6.971 & $0.55^{* * *}$ & 3.033 & $0.014 * * *$ & 5.743 & 0.53 & 1.212 \\
\hline$(0,+10)$ & $0.000^{* * *}$ & 3.715 & 0.50 & 0.032 & -0.002 & 1.415 & 0.48 & -0.779 \\
\hline$(0,+15)$ & -0.004 & 1.104 & 0.49 & -0.668 & -0.003 & 1.274 & 0.48 & -0.779 \\
\hline
\end{tabular}

Note (1): ***, and *** indicate statistical significance at $10 \%, 5 \%$, and $1 \%$ levels respectively.

(2): We obtained similar results by using the market-adjusted model.

\subsection{Factors Affecting Acquiring Firms' Short-term Performance}

In this section we report the impact of various deal-specific factors and firm characteristics on short-term performance. We present results from both univariate and multivariate analyses for the following factors to test our hypotheses presented in Chapter 3: Tender or merger offer (hypothesis ST2), private or public target (hypothesis ST3), related or unrelated acquisition (hypothesis ST4), methods of payment (hypothesis ST5), growth or value firms (hypothesis ST6), board independence (hypothesis ST7), managerial ownership (hypothesis ST8), relative size (hypothesis ST9), and takeover premium (hypothesis ST10). For hypothesis ST10, we present only multivariate regression results. 


\subsubsection{Univariate Analysis}

We used standard event analysis (Lin \& McConnell, 1983) to calculate CAR and adjusted

$\mathrm{CAR}$ and report the corresponding $\mathrm{Z}$ statistic for each factor separately ${ }^{35}$. Subsequently we calculated the mean CAR difference for relevant factors and reported t-statistics to check significance of mean differences. Results are presented in Table 4.3. For brevity, we focus on $\operatorname{CAR} 3(0,+2)$ for our discussion on results.

\section{Table 4.3 Factors Affecting Short-term Performance - Univariate Results}

We used the market model to determine the abnormal return and adjusted abnormal return. "CAR" is the average of the summation of the abnormal returns for each stock for a specific period. Six different versions of CAR were used in the analysis. The statistical significance of the abnormal return was examined by $Z$ statistics introduced by Lin and McConnell (1983). Standard deviation of AR was used in the test accounts for the first order correlation effect (please refer to Appendix $F$ for details). Mean difference for relevant factors and corresponding t-statistics are reported. Results are reported for different factors in Panel A to Panel I. In order to avoid extreme value (outlier) problems, the top 1\% and bottom 1\% of data of each variable included in the analysis are deleted. CAR results are reported in decimals.

Panel A. Tender or Merger offer

"Tender or merger" is a dummy variable. If the acquisition is completed through tender offer, the value is " 1 " and " 0 " otherwise.

\begin{tabular}{lllll}
\hline & CAR1 $(-1,+1)$ & CAR2 $(-2,+2)$ & CAR3 $(0,+2)$ & CAR4 (-5, +5) \\
\hline 1. Tender $(\mathrm{N}=120)$ & & & & 0.004 \\
Avg. CAR & -0.004 & 0.002 & -0.002 & 1.078 \\
Z-stat & -0.322 & 0.783 & -0.633 & \\
& & & \\
2. Merger $(\mathrm{N}=869)$ & & & \\
Avg. CAR & $0.015^{* * *}$ & $0.018^{* * *}$ & $0.015^{* * *}$ & $0.014 * * *$ \\
Z-stat & 9.990 & 9.818 & 10.912 & -036 \\
Mean Diff $(1-2)$ & $-0.019 * * *$ & $-0.016^{* *}$ & $-0.017^{* * *}$ & -0.010 \\
t-stat & -3.178 & -2.161 & -2.617 & -0.977 \\
Sig. & 0.002 & 0.032 & 0.010 & 0.329 \\
\hline Note: *, **, and $* * *$ indicate statistical significance at 10\%, 5\%, and 1\% levels respectively.
\end{tabular}

\footnotetext{
${ }^{35}$ We considered all cases including multiple acquirers in the analysis. We found that there is no significant difference in results for analyses with and without multiple acquirers in the same calendar year.
} 
Panel B. Public or Private Target

If the target firm was listed on the stock market, it was considered public. If it was not listed, it was considered private. "Others" include subsidiaries, joint ventures, etc.

\begin{tabular}{|c|c|c|c|c|}
\hline & CAR1 $(-1,+1)$ & CAR2 $(-2,+2)$ & CAR3 $(0,+2)$ & CAR4 $(-5,+5)$ \\
\hline \multicolumn{5}{|l|}{ 1. Public $(\mathrm{N}=337)$} \\
\hline Avg. CAR & 0.002 & $0.002^{* *}$ & $0.001^{* *}$ & $0.008 * * *$ \\
\hline Z-stat & 1.568 & 2.081 & 2.100 & 3.537 \\
\hline \multicolumn{5}{|l|}{ 2. Private $(\mathrm{N}=331)$} \\
\hline Avg. CAR & $0.024 * * *$ & $0.026 * * *$ & $0.020^{* * *}$ & $0.017 * * *$ \\
\hline Z-stat & 8.976 & 8.004 & 8.344 & 4.777 \\
\hline \multicolumn{5}{|l|}{ 3. Others $(N=321)$} \\
\hline Avg. CAR & $0.014 * * *$ & $0.019 * * *$ & $0.018^{* * *}$ & $0.011^{* * *}$ \\
\hline Z-stat & 5.519 & 6.373 & 6.943 & 3.761 \\
\hline Mean Diff $(1-2)$ & $-0.022 * * *$ & $-0.024 * * *$ & $-0.019 * * *$ & -0.009 \\
\hline t-stat & -3.705 & -3.283 & -2.998 & -0.857 \\
\hline Sig. & 0.000 & 0.001 & 0.002 & 0.391 \\
\hline Mean Diff $(1-3)$ & $-0.012^{* *}$ & $-0.017 * * *$ & $-0.017^{* * *}$ & -0.004 \\
\hline t-stat & -2.455 & -2.682 & -2.977 & -0.386 \\
\hline Sig. & 0.014 & 0.007 & 0.003 & 0.699 \\
\hline Mean Diff $(2-3)$ & 0.009 & 0.007 & 0.002 & 0.005 \\
\hline t-stat & 1.555 & 0.980 & 0.370 & 0.544 \\
\hline Sig. & 0.120 & 0.328 & 0.711 & 0.587 \\
\hline
\end{tabular}

Panel C. Related or unrelated acquisitions

"Related/unrelated acquisition" is a dummy variable. For related acquisitions, the value is " 1 " and " 0 " otherwise. It is determined based on the SIC code of the acquiring firm and the target firm. Two versions of this dummy variable are created, based on: (i) 4-digit SIC code, and (ii) 2-digit SIC code. Here we report the results for 4-digit SIC code analysis only. Results are similar for 2-digit SIC code analysis.

\begin{tabular}{|c|c|c|c|c|}
\hline & CAR1 $(-1,+1)$ & CAR2 $(-2,+2)$ & CAR3 $(0,+2)$ & $\operatorname{CAR} 4(-5,+5)$ \\
\hline \multicolumn{5}{|c|}{ 1. Related 4 Digits $(\mathrm{N}=435)$} \\
\hline Avg. CAR & $0.008 * * *$ & $0.009 * * *$ & $0.007 * * *$ & $0.007 * * *$ \\
\hline Z-stat & 4.349 & 3.943 & 3.810 & 4.160 \\
\hline \multicolumn{5}{|c|}{ 2. Unrelated 4 Digits $(N=554)$} \\
\hline Avg. CAR & $0.017^{* * *}$ & $0.021^{* * *}$ & $0.018^{* * *}$ & $0.016^{* * *}$ \\
\hline Z-stat & 8.508 & 9.167 & 9.996 & 5.628 \\
\hline Mean Diff (1-2) & $-0.008^{*}$ & $-0.012 * *$ & $-0.011^{* *}$ & -0.009 \\
\hline t-stat & -1.754 & -2.110 & -2.153 & -1.072 \\
\hline Sig. & 0.080 & 0.035 & 0.032 & 0.284 \\
\hline
\end{tabular}


Panel D. Methods of payment

Whether the acquisition is made through cash payment (category 1), stock payment (category 2), or mixed payment (category 3).

\begin{tabular}{lllll}
\hline & CAR1 $(-1,+1)$ & CAR2 $(-2,+2)$ & CAR3 $(0,+2)$ & CAR4 $(-5,+5)$ \\
\hline $\begin{array}{llll}\text { 1. Cash }(\mathrm{N}=596) \\
\text { Avg. CAR }\end{array}$ & $0.013^{* * *}$ & $0.017^{* * *}$ & $0.014^{* * *}$ & $0.014^{* * *}$ \\
Z-stat & 7.309 & 7.989 & 8.278 & 5.249 \\
& & & & \\
2. Stock $(\mathrm{N}=137)$ & & & & \\
Avg. CAR & $0.011^{* *}$ & 0.009 & -0.001 & $0.009^{* *}$ \\
Z-stat & 2.526 & 1.580 & 1.296 & 2.015 \\
& & & & \\
3. Mixed $(\mathrm{N}=256)$ & & & & \\
Avg. CAR & $0.015^{* * *}$ & $0.016^{* * *}$ & $0.017^{* * *}$ & $0.010^{* * *}$ \\
Z-stat & 5.185 & 5.281 & 6.093 & 4.219 \\
& & & & \\
Mean Diff $(1-2)$ & 0.002 & 0.008 & 0.015 & 0.005 \\
t-stat & 0.239 & 0.708 & 1.506 & 0.258 \\
Sig. & 0.811 & 0.480 & 0.134 & 0.797 \\
& & & & \\
Mean Diff $(1-3)$ & -0.001 & 0.001 & -0.003 & 0.004 \\
t-stat & -0.281 & 0.172 & -0.490 & 0.407 \\
Sig. & 0.779 & 0.863 & 0.624 & 0.685 \\
& & & & \\
Mean Diff $(2-3)$ & -0.004 & -0.007 & -0.018 & -0.001 \\
t-stat & -0.369 & -0.569 & -1.633 & -0.055 \\
Sig. & 0.713 & 0.570 & 0.104 & 0.956 \\
\hline
\end{tabular}

Note: *, **, and $* * *$ indicate statistical significance at $10 \%, 5 \%$, and $1 \%$ levels respectively.

Panel E. Growth or value acquirers

"Growth or value" is a dummy variable. The value is " 1 " if the acquiring firm's price-to-book value ratio is greater than " 1 " and " 0 " otherwise.

\begin{tabular}{|c|c|c|c|c|}
\hline & CAR1 $(-1,+1)$ & CAR2 $(-2,+2)$ & $\operatorname{CAR} 3(0,+2)$ & CAR4 $(-5,+5)$ \\
\hline \multicolumn{5}{|c|}{ 1. Growth Firms $(\mathrm{N}=854)$} \\
\hline Avg. CAR & $0.013^{* * *}$ & $0.017^{* * *}$ & $0.013^{* * *}$ & $0.014 * * *$ \\
\hline Z-stat & 8.513 & 9.213 & 9.418 & 7.021 \\
\hline \multicolumn{5}{|c|}{ 2. Value Firms $(N=107)$} \\
\hline Avg. CAR & $0.018^{* * *}$ & $0.012^{* *}$ & $0.019^{* * *}$ & 0.003 \\
\hline Z-stat & 3.280 & 2.235 & 4.219 & 1.426 \\
\hline Mean Diff $(1-2)$ & -0.005 & 0.005 & -0.006 & 0.011 \\
\hline t-stat & -0.660 & 0.500 & -0.646 & 0.735 \\
\hline Sig. & 0.510 & 0.618 & 0.519 & 0.464 \\
\hline
\end{tabular}


Panel F. Chair is related or not

"Chair is related" is a dummy variable and is equal to " 1 " if the chair is related to management or the board, " 0 " otherwise. For example, if the CEO is also chair of the board, the dummy variable is equal to "1".

\begin{tabular}{|c|c|c|c|c|}
\hline & CAR1 $(-1,+1)$ & CAR2 $(-2,+2)$ & CAR3 $(0,+2)$ & CAR4 $(-5,+5)$ \\
\hline \multicolumn{5}{|c|}{ 1. Chair Related $(\mathrm{N}=370)$} \\
\hline Avg. CAR & $0.016^{* * *}$ & $0.022 * * *$ & $0.013^{* * *}$ & $0.017^{* * *}$ \\
\hline Z-stat & 6.728 & 7.055 & 6.090 & 4.310 \\
\hline \multicolumn{5}{|c|}{ 2. Chair Unrelated $(\mathrm{N}=237)$} \\
\hline Avg. CAR & $0.018^{* * *}$ & $0.019 * * *$ & $0.021 * * *$ & $0.019 * * *$ \\
\hline Z-stat & 5.900 & 4.835 & 6.840 & 3.976 \\
\hline Mean Diff $(1-2)$ & -0.003 & 0.003 & -0.009 & -0.002 \\
\hline t-stat & -0.444 & 0.339 & -1.246 & -0.226 \\
\hline Sig. & 0.657 & 0.735 & 0.213 & 0.822 \\
\hline
\end{tabular}

Note: $*{ }^{* *}$, and ${ }^{* * *}$ indicate statistical significance at $10 \%, 5 \%$, and $1 \%$ levels respectively.

Panel G. Board Independence

"Board independence" is a dummy variable. The value is " 1 " if the majority of the board members are unrelated and "0" otherwise.

\begin{tabular}{|c|c|c|c|c|}
\hline & CAR1 $(-1,+1)$ & CAR2 $(-2,+2)$ & $\operatorname{CAR3}(0,+2)$ & CAR4 $(-5,+5)$ \\
\hline \multicolumn{5}{|c|}{ 1. Independent $(\mathrm{N}=510)$} \\
\hline Avg. CAR & $0.016^{* * *}$ & $0.020^{* * *}$ & $0.015^{* * *}$ & $0.019 * * *$ \\
\hline Z-stat & 7.976 & 7.478 & 8.002 & 5.410 \\
\hline \multicolumn{5}{|c|}{ 2. Dependent $(\mathrm{N}=90)$} \\
\hline Avg. CAR & $0.020^{* * *}$ & $0.027^{* * *}$ & $0.019^{* * *}$ & $0.009^{* *}$ \\
\hline Z-stat & 3.940 & 4.249 & 4.206 & 2.188 \\
\hline Mean Diff $(1-2)$ & -0.004 & -0.007 & -0.004 & 0.010 \\
\hline t-stat & -0.386 & -0.645 & -0.344 & 0.673 \\
\hline Sig. & 0.700 & 0.520 & 0.732 & 0.503 \\
\hline
\end{tabular}


Panel H. Managerial ownership

We used director ownership as a proxy for managerial ownership of the firm. Director ownership is the percentage of outstanding shares owned by all directors (including the CEO) of the firm. Subsequently, three categories are created for director ownership namely, for less than 5\%,5-25\%, and more than $25 \%$.

\begin{tabular}{|c|c|c|c|c|}
\hline & CAR1 $(-1,+1)$ & $\operatorname{CAR2}(-2,+2)$ & CAR3 $(0,+2)$ & CAR4 $(-5,+5)$ \\
\hline \multicolumn{5}{|c|}{ 1. Less than $5 \%(\mathrm{~N}=310)$} \\
\hline Avg. CAR & $0.016^{* * *}$ & $0.017 * * *$ & $0.018 * * *$ & $0.022 * * *$ \\
\hline Z-stat & 5.509 & 4.202 & 6.538 & 3.517 \\
\hline \multicolumn{5}{|c|}{2.5 to $25 \%(\mathrm{~N}=220)$} \\
\hline Avg. CAR & $0.009 * * *$ & $0.011^{* * *}$ & $0.002^{* * *}$ & $-0.006^{*}$ \\
\hline Z-stat & 3.766 & 3.995 & 2.617 & 1.856 \\
\hline \multicolumn{5}{|c|}{ 3. More than $25 \%(N=137)$} \\
\hline Avg. CAR & $0.027^{* * *}$ & $0.036^{* * *}$ & $0.031^{* * *}$ & $0.036^{* * *}$ \\
\hline Z-stat & 6.337 & 7.236 & 7.773 & 5.234 \\
\hline Mean Diff $(1-2)$ & 0.007 & 0.006 & $0.015^{* *}$ & $0.028^{* *}$ \\
\hline t-stat & 0.978 & 0.654 & 2.021 & 2.337 \\
\hline Sig. & 0.328 & 0.514 & 0.044 & 0.020 \\
\hline Mean Diff $(1-3)$ & -0.011 & $-0.020 * *$ & $-0.014 *$ & -0.013 \\
\hline t-stat & -1.396 & -2.120 & -1.668 & -1.006 \\
\hline Sig. & 0.164 & 0.035 & 0.096 & 0.315 \\
\hline Mean Diff $(2-3)$ & $-0.018^{* *}$ & $-0.025 * *$ & $-0.029 * * *$ & $-0.042 * * *$ \\
\hline t-stat & -2.051 & -2.472 & -3.339 & -2.723 \\
\hline Sig. & 0.041 & 0.014 & 0.001 & 0.007 \\
\hline
\end{tabular}

Note: ${ }^{*}, * *$ and ${ }^{* * *}$ indicate statistical significance at $10 \%, 5 \%$, and $1 \%$ levels respectively. 
Panel I. Relative Size

"Relative size" is the ratio of transaction value to market value of the acquiring firm's equity. Subsequently, three categories are created for relative size, namely, for less than $5 \%, 5-25 \%$, and more than $25 \%$.

\begin{tabular}{|c|c|c|c|c|c|c|}
\hline & $\begin{array}{l}\text { CAR1 } \\
(-1,+1)\end{array}$ & $\begin{array}{l}\text { CAR2 } \\
(-2,+2)\end{array}$ & $\begin{array}{l}\text { CAR3 } \\
(0,+2)\end{array}$ & $\begin{array}{l}\text { CAR4 } \\
(-5,+5)\end{array}$ & $\begin{array}{l}\text { CAR5 } \\
(0,+10)\end{array}$ & $\begin{array}{l}\text { CAR6 } \\
(0,+15)\end{array}$ \\
\hline \multicolumn{7}{|c|}{ 1. Less than $5 \%(\mathrm{~N}=418)$} \\
\hline Avg. CAR & $0.005 * *$ & $0.005^{* * *}$ & $0.006 * * *$ & $0.004^{* *}$ & 0.000 & 0.001 \\
\hline Z-stat & 2.403 & 3.139 & 4.079 & 2.034 & 0.704 & 0.841 \\
\hline \multicolumn{7}{|c|}{2.5 to $25 \%(\mathrm{~N}=301)$} \\
\hline Avg. CAR & $0.016^{* * *}$ & $0.023^{* * *}$ & $0.019 * * *$ & $0.018 * * *$ & 0.001 & -0.001 \\
\hline Z-stat & 7.011 & 7.166 & 8.243 & 4.510 & 0.762 & 0.772 \\
\hline \multicolumn{7}{|c|}{ 3. More than $25 \%(N=183)$} \\
\hline Avg. CAR & $0.030^{* * *}$ & $0.033^{* * *}$ & $0.024 * * *$ & $0.032 * * *$ & $0.013 * * *$ & $-0.001 *$ \\
\hline Z-stat & 7.679 & 7.132 & 6.228 & 7.274 & 4.170 & 1.877 \\
\hline Mean Diff $(1-2)$ & $-0.011 * *$ & $-0.018 * * *$ & $-0.013^{* *}$ & -0.014 & -0.001 & 0.001 \\
\hline t-stat & -2.156 & -2.952 & -2.322 & -1.578 & -0.167 & 0.138 \\
\hline Sig. & 0.031 & 0.003 & 0.021 & 0.115 & 0.867 & 0.890 \\
\hline Mean Diff $(1-3)$ & $-0.025 * * *$ & $-0.028 * * *$ & $-0.017^{* *}$ & $-0.028 * *$ & -0.013 & 0.002 \\
\hline t-stat & -3.158 & -2.889 & -2.071 & -2.160 & -0.986 & 0.093 \\
\hline Sig. & 0.002 & 0.004 & 0.039 & 0.032 & 0.325 & 0.926 \\
\hline Mean Diff $(2-3)$ & $-0.014^{*}$ & -0.009 & -0.005 & -0.014 & -0.012 & 0.000 \\
\hline t-stat & -1.671 & -0.903 & -0.527 & -0.972 & -0.851 & 0.007 \\
\hline Sig. & 0.096 & 0.367 & 0.598 & 0.332 & 0.395 & 0.995 \\
\hline
\end{tabular}

\section{Tender or Merger Offer}

From Table 4.3, Panel A, we found that there was no significant abnormal short-term return for tender offers. However, for merger offers, it was significantly positive (Z-stat = 10.91 for CAR3). Also, the mean difference between tenders and merger offers was negative and significant. This implies that the market reacts more positively for a merger offer compared to a tender offer. 


\section{Public or Private Target}

From Table 4.3, Panel B, we found that there was a significant positive abnormal return ${ }^{36}$ for all three categories of target type. Further, we found that the mean difference between public and private targets was negative and significant. This implies that the market reacts more positively for a private target compared to a public target.

\section{Related or Unrelated Acquisitions}

From Table 4.3, Panel C, we found that the mean difference between related and unrelated acquisition was negative and significant. This implies that the market reacts more positively for unrelated targets and values the diversification effect.

\section{Methods of Payment}

From Table 4.3, Panel D, we found that the market reacts positively and significantly for cash acquisitions. For stock acquisitions, the short-term abnormal return was not significant. However, the mean difference was not statistically significant.

\section{Growth or Value Acquirers}

From Table 4.3, Panel E, we found that the mean CAR difference between these two categories was not significant. It appears that there is no clear preference for growth or value acquirers.

\footnotetext{
${ }^{36}$ This is not surprising, given that we observe very strong positive abnormal return around announcement period for all acquisition cases.
} 


\section{Board Independence}

We used two variables to denote board independence: (i) whether or not the Chair is related (results are presented in Table 4.3, Panel F), and (ii) whether or not the majority of the board members are unrelated (results are presented in Table 4.3, Panel G). In both situations, we did not find any significant mean CAR difference between (i) chair is related vs. chair is unrelated, and (ii) board is independent vs. board is dependent. It appears that there is no clear impact on short-term abnormal return for board independence.

\section{Managerial Ownership}

We used director ownership as a proxy for managerial ownership. From Table 4.3, Panel $\mathrm{H}$, we found that there was a positive and significant short-term abnormal return for all three categories of managerial ownership (i.e. less than $5 \%, 5$ to $25 \%$, more than $25 \%$ ). However, we found interesting results when we examined the mean differences between these categories. According to Morck et al., (1988), there will be "convergence of interest" with a firm's value maximizing objective if the managerial ownership is quite high (for example, more than 25\%). Alternatively, if the managerial ownership is not too low and not too high (for example, between 5 and 25\%), they are more likely to pursue non-value maximizing activities. We find that the mean differences between (i) category $2(5$ to $25 \%$ ) and 3 (more than 25\%), and (ii) category 1 (less than $5 \%$ ) and 3 (more than $25 \%$ ) are significantly negative. This implies that the market values deals positively if the managerial ownership in the corresponding acquiring firm is high. 


\section{Relative Size}

From Table 4.3, Panel I, we found that there is a positive and significant short-term abnormal return for all three categories of relative size (i.e., less than $5 \%, 5$ to $25 \%$, more than $25 \%$ ). However, we found interesting results when we calculated the mean differences between these categories. Differences in short-term return (i) between the middle (5 to $25 \%$ ) and small (less than $5 \%$ ) relative size groups, and (ii) between the large (more than 25\%) and small (less than $5 \%$ ) relative size groups are positive and significant. In other words, the market reacts more positively for the relatively larger deals because of their larger economic impact. Further, we found that CAR $(0,+10)$ was significantly positive for the large relative size group. However, such overreaction was corrected in the subsequent period (negative CAR $(0,+15))$.

\subsubsection{Multivariate Analysis}

To augment the univariate results and to investigate confounding impact of various independent variables, Table 4.4 presents the results for multivariate analysis. We used OLS regression to obtain our results. Results are presented separately for (i) deal specific variables and firm operating characteristics, and (ii) governance variables, in Panel A and Panel B respectively. 
Table 4.4 Factors Affecting Short-term Performance - Multivariate Analysis ${ }^{37}$

OLS regression of cumulative abnormal return (CAR) $(0,+2)$ on (i) deal specific variables and firm operating characteristics, and (ii) governance variables. "CAR" is the average of the summation of the abnormal returns for each stock for a specific period.

Deal specific variables and firm operating characteristics: "Market value" is the year-end market value of firm's equity as reported in the Stock Guide Database. "Price to book value" is the ratio of the firm's market value to book value in the prior year. "Tender or merger" is a dummy variable. If the acquisition is completed through tender offer, the value is " 1 " and " 0 " otherwise. "Related/unrelated acquisition" is a dummy variable. For related acquisition, the value is " 1 " and " 0 " otherwise. It is determined based on the SIC code of the acquiring firm and the target firm. Two versions of this dummy variable are created based on: (i) 4-digit SIC code, and (ii) 2-digit SIC code. "Target type"" is a categorical variable outlining the nature of the target firm. Three categories are created: (i) public target (pubprv1), (ii) private target (pubprv2), and (iii) other (subsidiaries, joint ventures etc.) (pubprv3). "Payment type" is a categorical variable outlining the nature of the transaction payment mode. Three categories are created: (i) cash payment (paytype1), (ii) stock payment (paytype2), and (iii) mixed or other (paytype3). "Cross border target (CrsBd2_3)" is a dummy variable. The value is " 1 " if the target is from outside Canada or the US and "0" otherwise. "Target Premium" is the gain to the target shareholders due to takeover announcements. Two methods are used to proxy for "target premium." First, we used cumulative abnormal return for the target firm over " -30 days to +30 days" to calculate target premium (Crawford and Lechner, 1996) ${ }^{38}$. Second, we calculated target premiums using offer price and pre-announcement stock price at "day -15 ," adjusting for market movement (St-Pierre, 1994) ${ }^{39}$. "Relative size" is the ratio of transaction value and market value of the acquiring firm's equity.

Governance variables: "Chair is related" is a dummy variable and is equal to " 1 " if the chair is related to management or the board, " 0 " otherwise. For example, if the CEO is also chair of the board, the dummy variable is equal to " 1 ". "Percentage of inside directors" is the ratio of related directors to total board size. "Blockholder ownership" is the percentage of outstanding shares owned by individuals or institutions other than the directors. If the blockholder ownership is less than $10 \%$, the input value for this variable is " 0 ". Subsequently, three categories are created for blockholder ownership, namely, for less than $10 \%, 10-25 \%$, and more than $25 \%$. "CEO ownership" is the percentage of outstanding shares owned by the CEO. Subsequently, three categories are created for CEO ownership, namely, for less than 5\%,5-25\%, and more than $25 \%$. "Director ownership" is the percentage of outstanding shares owned by all directors (including the CEO) of the firm. Subsequently, three categories are created for director ownership namely, for less than $5 \%, 5-25 \%$, and more than $25 \%$. t-statistics and corresponding significance level are reported. We used a dummy variable to control for "year" and "industry" effects in each model. In order to avoid extreme value (outlier) problem, the top $1 \%$ and bottom $1 \%$ data of each variable included in the analysis were deleted.

\footnotetext{
${ }^{37}$ Multicollinearity is tested for each independent variable by checking the variance inflation factor (VIF) and the structure of lower eigenvalue factors reported in SPSS collinearity diagnostics tables.

${ }^{38}$ As pointed out by Crawford and Lechner (1996), there are a number of advantages to this approach: (i) Target premiums can be calculated for all publicly traded targets irrespective of payment type, (ii) It considers the wealth effect for target shareholders around the announcement date, hence giving a broader view of target premium.

${ }^{39}$ Target premium $=\left(\left(\mathrm{OP}_{t}-\mathrm{P}_{\mathrm{t}-15}\right) / \mathrm{P}_{\mathrm{t}-15}\right)-\left(\left(\mathrm{I}_{\mathrm{t}}-\mathrm{I}_{\mathrm{t}-15}\right) / \mathrm{I}_{\mathrm{t}-15}\right)$, where, $\mathrm{OP}_{\mathrm{t}}=$ Price offered for the target shares at the announcement date. $P_{t-15}$ is the market value of the target shares 15 days prior to the announcement date. $I_{t}$ and $I_{t-15}$ are the Index values at the announcement date and 15 days prior to the announcement date respectively. This approach is applicable only for cash offer and listed target firms.
} 
Panel A. Deal specific variables and firm operating characteristics

\begin{tabular}{|c|c|c|c|c|c|}
\hline & & Model 1 & Model 2 & Model 3 & Model 4 \\
\hline \multirow[t]{3}{*}{ (Constant) } & Beta & $0.053 * *$ & $0.055^{* * *}$ & $0.057 * * *$ & 0.061 \\
\hline & t-stat & 2.471 & 2.762 & 2.880 & 0.569 \\
\hline & Sig. & 0.014 & 0.006 & 0.004 & 0.571 \\
\hline \multirow[t]{3}{*}{ Log of Market Value (LNMMVAL) } & Beta & -0.002 & -0.001 & -0.002 & 0.003 \\
\hline & t-stat & -1.101 & -1.026 & -1.203 & 0.572 \\
\hline & Sig. & 0.271 & 0.305 & 0.229 & 0.569 \\
\hline Related/Unrelated acquisition & Beta & $-0.015^{* * *}$ & $-0.015 * * *$ & $-0.015^{* * *}$ & \\
\hline \multirow[t]{2}{*}{ (REL4DIG) } & $t$-stat & -3.314 & -3.287 & -3.378 & \\
\hline & Sig. & 0.001 & 0.001 & 0.001 & \\
\hline \multirow[t]{3}{*}{ Price to book value (PRBV1) } & Beta & $-0.001 *$ & -0.001 & $-0.001 *$ & \\
\hline & $t$-stat & -1.666 & -1.629 & -1.681 & \\
\hline & Sig. & 0.096 & 0.104 & 0.093 & \\
\hline \multirow{3}{*}{ Payment type - cash (PAYTYPE1) } & Beta & 0.003 & 0.002 & 0.002 & \\
\hline & $t$-stat & 0.631 & 0.429 & 0.415 & \\
\hline & Sig. & 0.528 & 0.668 & 0.678 & \\
\hline \multirow[t]{3}{*}{ Payment type - stock (PAYTYPE2) } & Beta & -0.011 & $-0.013 *$ & -0.012 & \\
\hline & $t$-stat & -1.449 & -1.730 & -1.636 & \\
\hline & Sig. & 0.148 & 0.084 & 0.102 & \\
\hline \multirow{3}{*}{ Target type - public (PUBPRV1) } & Beta & $-0.009 *$ & & & \\
\hline & $t$-stat & -1.645 & & & \\
\hline & Sig. & 0.100 & & & \\
\hline \multirow[t]{3}{*}{ Target type - private PUBPRV2 } & Beta & 0.001 & & & \\
\hline & $t$-stat & 0.143 & & & \\
\hline & Sig. & 0.887 & & & \\
\hline \multirow[t]{3}{*}{ Log of relative size (LNRELSZ1) } & Beta & $0.003 *$ & $0.003 * *$ & $0.003 * *$ & -0.004 \\
\hline & t-stat & 1.700 & 2.083 & 2.105 & -0.731 \\
\hline & Sig. & 0.089 & 0.038 & 0.036 & 0.467 \\
\hline \multirow[t]{3}{*}{ Tender/ Merger offer (TENMER) } & Beta & & $-0.016 * *$ & $-0.015^{* *}$ & \\
\hline & $t$-stat & & -2.352 & -2.135 & \\
\hline & Sig. & & 0.019 & 0.033 & \\
\hline \multirow[t]{3}{*}{ Cross border target (CRSBD2_3) } & Beta & & & $0.011 * *$ & \\
\hline & t-stat & & & 1.963 & \\
\hline & Sig. & & & 0.050 & \\
\hline \multirow[t]{3}{*}{ Target premium (PREMIUM1) } & Beta & & & & $0.047^{* *}$ \\
\hline & $t$-stat & & & & 2.481 \\
\hline & Sig. & & & & 0.015 \\
\hline R Square & & 0.055 & 0.057 & 0.061 & 0.281 \\
\hline Adjusted R Square & & 0.031 & 0.034 & 0.038 & 0.127 \\
\hline $\mathbf{F}$ & & 2.311 & 2.529 & 2.600 & 1.828 \\
\hline Sig. & & 0.001 & 0.000 & 0.000 & 0.043 \\
\hline $\mathrm{N}$ & & 863 & 863 & 863 & 92 \\
\hline
\end{tabular}


Panel B. Governance variables

\begin{tabular}{|c|c|c|c|c|}
\hline & & Model 1 & Model 2 & \\
\hline \multirow[t]{3}{*}{ (Constant) } & Beta & 0.043 & $0.060 *$ & \\
\hline & $t$-stat & 1.454 & 1.930 & \\
\hline & Sig. & 0.147 & 0.054 & \\
\hline \multirow[t]{3}{*}{ Log of market value (LNMMVAL) } & Beta & -0.001 & -0.002 & \\
\hline & $t$-stat & -0.669 & -1.170 & \\
\hline & Sig. & 0.504 & 0.243 & \\
\hline \multirow[t]{3}{*}{ Log of relative size (LNRELSZ1) } & Beta & 0.003 & 0.003 & \\
\hline & $t$-stat & 1.301 & 1.420 & \\
\hline & Sig. & 0.194 & 0.156 & \\
\hline Related/ unrelated acquisition & Beta & $-0.020 * * *$ & $-0.019 * * *$ & \\
\hline \multirow[t]{2}{*}{ (REL4DIG) } & $t$-stat & -3.162 & -3.070 & \\
\hline & Sig. & 0.002 & 0.002 & \\
\hline \multirow[t]{3}{*}{ Chair is related (CHRREL) } & Beta & -0.008 & -0.008 & \\
\hline & $t$-stat & -1.156 & -1.203 & \\
\hline & Sig. & 0.248 & 0.230 & \\
\hline \multirow[t]{3}{*}{ Percentage of inside directors (PINDIR) } & Beta & 0.003 & 0.008 & \\
\hline & $t$-stat & 0.136 & 0.390 & \\
\hline & Sig. & 0.892 & 0.697 & \\
\hline Blockholder ownership (10 to $25 \%$ ) & Beta & -0.012 & -0.010 & \\
\hline \multirow[t]{2}{*}{ (BLKOWN2) } & $t$-stat & -1.190 & -1.004 & \\
\hline & Sig. & 0.235 & 0.316 & . \\
\hline Blockholder ownership (more than $25 \%$ ) & Beta & 0.004 & 0.005 & \\
\hline \multirow[t]{2}{*}{ BLKOWN3 } & t-stat & 0.416 & 0.571 & \\
\hline & Sig. & 0.677 & 0.568 & \\
\hline CEO ownership ( 5 to $25 \%$ ) & Beta & 0.011 & & \\
\hline \multirow{2}{*}{$(\mathrm{CEOOWN} 2)$} & $t$-stat & 1.359 & & \\
\hline & Sig. & 0.175 & & \\
\hline CEO ownership (more than $25 \%$ ) & Beta & 0.014 & & \\
\hline \multirow[t]{2}{*}{ (CEOOWN3) } & t-stat & 1.426 & & \\
\hline & Sig. & 0.154 & & \\
\hline Director ownership ( 5 to $25 \%$ ) & Beta & & -0.012 & \\
\hline \multirow[t]{2}{*}{ (DIROWN2) } & $t$-stat & & -1.474 & \\
\hline & Sig. & & 0.141 & \\
\hline Director ownership (more than $25 \%$ ) & Beta & & $0.021 * *$ & \\
\hline \multirow[t]{2}{*}{ (DIROWN3) } & t-stat & & 2.227 & \\
\hline & Sig. & & 0.026 & \\
\hline R Square & & 0.065 & 0.089 & \\
\hline Adjusted R Square & & 0.031 & 0.057 & \\
\hline $\mathbf{F}$ & & 1.933 & 2.740 & \\
\hline Sig. & & 0.012 & 0.000 & \\
\hline $\mathbf{N}$ & & 520 & 521 & \\
\hline
\end{tabular}




\section{Deal Specific Variables and Firms' Operating Characteristics}

Corresponding results are presented in Table 4.4, Panel A with the help of four regression models. As tender offer and target types are highly correlated, results for these variables are presented as separate models. The results for "target premium" variables are reported separately in Model 4, as the inclusion of this variable reduces the sample size dramatically ${ }^{40}$. There are a number of interesting observations. First, we found that there are significant negative abnormal returns (significance level 0.001 in model 1, 2 and 3) for related acquisition (with respect to unrelated acquisition). This implies that the market values the diversification effect more positively. Second, the market reacts negatively for growth firms compared to the value firms, implying that the market believes that in growth firms, managers are more likely to overestimate their capabilities (Rau \& Vermaelen, 1998). However, this variable is significant only at $10 \%$ level. Third, we found that relative size has a significant positive impact on short-term abnormal return (significant at $5 \%$ level in model 2 and 3). Two possible explanations for this observation are as follows: (i) acquisition of a relatively large target is likely to be a more important economic event for the acquirer than is the acquisition of a relatively small target (Eckbo et al., 1990) and higher relative size could have more synergies (positive effects), and (ii) management spends more time and effort in evaluating larger acquisition deals. The market recognizes this management effort and reacts positively for relatively larger acquisition deals. Fourth, we also tested the impact of cross-border acquisitions by using a dummy variable. If the target is from outside Canada and the US, the value of the dummy variable is " 1 ", and " 0 " otherwise. The coefficient of this dummy variable is positive and significant at 5\% level (Model 3). This implies that the market participants

\footnotetext{
${ }^{40}$ Target premium is calculated only for the publicly traded targets listed on Toronto Stock Exchange.
} 
react positively if targets are from outside Canada or the US. Fifth, target premiums have a significant positive impact (significance level is 0.015 in model 4 ) on short-term abnormal return. This is a surprising observation as conventional wisdom suggests that if acquirers are paying a very high price for the target, accordingly, the market should react negatively for such instances. One possible explanation for such observation is that the market believes targets with higher premiums are better acquisition choices for the acquiring firms and shareholders are likely to pay a premium for such announcements. Similarly, higher takeover premiums could have been driven by the relative size of the deals as relatively larger deals carry more economic significance. In order to test this conjecture, we regressed takeover premiums on relative size, controlling for year and industry effect. We found that relative size has a positive and significant (at 0.05 level) impact on takeover premiums ${ }^{41}$ (results not reported). However, this issue should be investigated further as the sample size is quite small (92 cases) for the corresponding regression model. Further we have considered only the completed deals in our analysis, which gives us only a partial picture ${ }^{42}$. Finally, we also found marginal support for negative reaction in the market for stock financed deals (model 2, significance level is 0.084 ) and public targets (model 1, significance level is 0.10 ).

\section{Governance Variables}

Corresponding results are presented in Table 4.4, Panel B with the help of two regression models. Results for CEO ownership and directors' ownership are presented separately in

\footnotetext{
${ }^{41}$ Further we find that (chapter 6) long-term operating performance is significantly higher for larger relative size deals. This gives justification for higher takeover premium for relatively larger deals.

${ }^{42}$ As none of the earlier studies have investigated this issue in Canadian context, out findings could not be contrasted with previous results.
} 
Model 1 and Model 2 respectively, as both variables act as a proxy for managerial ownership. Consistent with our findings in the univariate analysis, we found that the market reacts positively if the managerial ownership in the corresponding acquiring firm is high (Model 2, significance level is 0.026 ). This finding is consistent with the "convergence-of-interest" argument that Morck et al. (1988) posit. None of the other governance variables' coefficients are significant.

Once we combined the findings of univariate and multivariate analyses, the following conclusions emerge. With respect to short-term abnormal return, we found that overall, there is a significant and positive abnormal return for the acquiring firm shares around the announcement date. The results are robust across single acquirers and multiple acquirers ${ }^{43}$. This finding is different from the ones reported in most of the U.S. studies. The majority of the U.S. studies have reported negative or insignificant abnormal returns for the acquiring firms around the announcement date (see Appendix C). However, the results observed in this study are not surprising in the Canadian context, as all of the earlier Canadian studies have reported significant and positive abnormal returns around the announcement date although many of these studies are either dated or based on very small samples. (Calvet and Lefoll, 1987; Eckbo, 1986; Eckbo \& Thorburn, 2000; Masse et al., 1990; Yuce \& Ng, 2005). As discussed in chapter 1, possible explanation for such an observation includes: (i) more cash financing deals in Canada, (ii) less stringent antitrust regulation in Canada in comparison with the United States and less effective anti-takeover tactics adopted by target firms, (iii) larger relative size deals in Canada, and (iv) M\&A boom in 1990s (until 2000) and the market confidence in such activities. Since

\footnotetext{
${ }^{43}$ Multiple acquirers make more than one acquisition in a calendar year.
} 
the majority of the M\&A cases in this study falls within this time period, the results could be inclined towards positive abnormal return by simply following the market trend.

Further, we investigated the impact of various deal specific, firm specific, and governance variables on acquirers' short-term return. We found that the market reacts more favorably to the (i) unrelated acquisitions as compared to the related acquisitions favoring the diversification effect as opposed to the synergy effect (Eckbo \& Thorburn, 2000), (ii) relatively larger deals as compared to relatively smaller deals ${ }^{44}$ - considering the economic significance of larger deals (Eckbo et al., 1990; Eckbo \& Thorburn, 2000), (iii) deals involving target firms from outside Canada and the United States, considering the diversification effect, (iv) deals involving private targets as compared to public targets -considering a liquidity discount for the private targets and limited competition (Fuller et al., 2002), (v) deals with higher target premium ${ }^{45}-$ considering that targets are highly valued by the management, and (vi) deals by acquiring firms with higher levels of managerial ownership - considering that management interest is aligned for such deals (Morck et al., 1988). We also found limited support for the hypothesis that the market reacts unfavorably for the deals that are (i) purely stock-financed compared to cash-financed - considering information asymmetry and valuation uncertainty surrounding stock deals (Fuller et al., 2002), and (ii) announced by growth firms compared to the value firms - considering that the growth firm's management is

\footnotetext{
${ }^{44}$ However, as we observe in table 4.3 (panel I), such high level of short-term abnormal return is not sustained for the large relative size groups beyond +10 day period (from the announcement date).

${ }^{45}$ We view this result with caution as the sample size for target premium is low (92). Target premiums were obtained only for the TSE listed target firms and for the completed deals.
} 
extremely confident and overpay for target firms (Roll, 1986; Hayward and Hambrick, 1997).

Two of the above mentioned observations are surprising. While conventional wisdom suggests that unrelated acquisitions and deals with higher target premium should be viewed less favorably in the market, our analysis presents opposite results. Eckbo and Thorburn (2000) report similar results with regards to unrelated acquisitions in Canadian context. However, we did not find any Canadian study to contrast our results on takeover premiums.

A summary of the results with respect to each hypothesis is presented in Table 4.5.

Table 4.5 Summary of the Short-term Performance Hypotheses Test Results

\begin{tabular}{|c|c|c|}
\hline Issue & Short Term Performance Hypothesis & Result \\
\hline $\begin{array}{l}\text { Overall } \\
\text { Performance }\end{array}$ & $\begin{array}{l}\text { Hypothesis ST1: Overall, there is positive and } \\
\text { significant cumulative abnormal return around } \\
\text { the announcement date for the bidding firms. }\end{array}$ & Supported (Fail to reject). \\
\hline $\begin{array}{l}\text { Tender or } \\
\text { Merger Offer }\end{array}$ & $\begin{array}{l}\text { Hypothesis ST2: Short-term performance for } \\
\text { acquiring firms is better for tender offers than } \\
\text { for mergers. }\end{array}$ & $\begin{array}{l}\text { Not supported. In univariate } \\
\text { analysis we find support for } \\
\text { positive and significant short- } \\
\text { term abnormal return for merger } \\
\text { offer. In multivariate analysis we } \\
\text { find that tender offers have } \\
\text { negative effects. }\end{array}$ \\
\hline $\begin{array}{l}\text { Private or } \\
\text { Public Target }\end{array}$ & $\begin{array}{l}\text { Hypothesis ST3: Short-term performance for } \\
\text { acquiring firms is better for the acquisition of } \\
\text { private target than for public target. }\end{array}$ & Supported (Fail to reject). \\
\hline $\begin{array}{l}\text { Related or } \\
\text { unrelated } \\
\text { Acquisition }\end{array}$ & $\begin{array}{l}\text { Hypothesis ST4: Short-term performance for } \\
\text { acquiring firms is better for related acquisition } \\
\text { than for unrelated acquisition (diversification). }\end{array}$ & $\begin{array}{l}\text { Not supported. We find support } \\
\text { for the opposite proposition - } \\
\text { short-term abnormal return is } \\
\text { better for unrelated acquisition. }\end{array}$ \\
\hline $\begin{array}{l}\text { Methods of } \\
\text { Payment }\end{array}$ & $\begin{array}{l}\text { Hypothesis ST5: Short-term performance for } \\
\text { acquiring firms is better for cash offer than for } \\
\text { stock transactions. }\end{array}$ & Supported (Fail to reject). \\
\hline
\end{tabular}




\begin{tabular}{|c|c|c|}
\hline Issue & Short Term Performance Hypothesis & Result \\
\hline $\begin{array}{l}\text { Growth or } \\
\text { Value Firms }\end{array}$ & $\begin{array}{l}\text { Hypothesis ST6: Short-term performance for } \\
\text { acquiring firms is better for value firms (low } \\
\text { market-to-book value) than for growth firms } \\
\text { (high market-to-book value). }\end{array}$ & Supported (Fail to reject). \\
\hline $\begin{array}{l}\text { Board } \\
\text { Independence }\end{array}$ & $\begin{array}{l}\text { Hypothesis ST7: Short-term performance is } \\
\text { better for bidding firms with independent } \\
\text { boards. }\end{array}$ & Not supported. \\
\hline $\begin{array}{l}\text { Managerial } \\
\text { Ownership }\end{array}$ & $\begin{array}{l}\text { Hypothesis ST8: Short-term performance is } \\
\text { better for bidding firms with higher managerial } \\
\text { ownership. }\end{array}$ & Supported (Fail to reject). \\
\hline Relative Size & $\begin{array}{l}\text { Hypothesis ST9: Acquiring firms perform } \\
\text { better with smaller M\&A deals (announcement } \\
\text { value) than with bigger deals in the short run } \\
\text { around the announcement date. }\end{array}$ & $\begin{array}{l}\text { Not supported. We find support } \\
\text { for the opposite proposition - } \\
\text { short-term abnormal return is } \\
\text { better for relatively larger deals. }\end{array}$ \\
\hline $\begin{array}{l}\text { Takeover } \\
\text { Premium }\end{array}$ & $\begin{array}{l}\text { Hypothesis ST10: Short-term abnormal return } \\
\text { will be higher for high target premium deals. }\end{array}$ & Supported (Fail to reject). \\
\hline
\end{tabular}




\section{CHAPTER 5: RESULTS: LONG-TERM STOCK RETURN PERFORMANCE}

In this chapter, we describe the results for long-term stock return performance subsequent to an acquisition event. We first describe the results for all acquisition events between 1993 and 2002 using the event-time approach (BHAR methodology) and the calendartime approach (Fama-French (F-F) three factor methodology). Subsequently, we present the results for the implications of various deal specific and firm specific factors on longterm return performance.

\subsection{Long-term Return Performance for an Acquisition Event}

In the section, we present the long-term stock return performance for all acquiring firms covering a 36-month post event period. As stated earlier, there has been serious debate over the reliability and appropriateness of different methodologies used in the extant literature to detect long-term stock return performance ${ }^{46}$ (Kothari \& Warner, 2005). Considering samples from the U.S., Canadian, and U.K. markets, some of the earlier studies have reported long-term underperformance for acquiring firms. Such results are puzzling considering that the markets in these developed countries are efficient. Fama (1998) has argued that such "anomalies are chance results" (p. 283) and questions the methodologies used in the literature, arguing "Consistent with the market efficiency prediction that apparent anomalies can be due to methodology, most long-term return anomalies tend to disappear with reasonable changes in technique" (Fama, 1998, p. 283).

\footnotetext{
${ }^{46}$ For a detailed discussion, please refer to Appendix G.
} 
We used both an event-time approach (buy and hold abnormal return) and a calendartime approach (F-F three factor regression) to mitigate methodological problems in reporting our results. Of these two methods, most criticisms are directed at the event-time approach (Mitchell \& Stafford, 2000). We took the following steps to account for serious criticisms with respect to the buy and hold abnormal return (BHAR) approach: (i) we used matching firm return as a benchmark (Barber \& Lyon, 1997) along with other benchmarks, (ii) we used skewness adjusted $t$ statistics (Lyon, Barber, \& Tsai, 1999); and (iii) we made adjustments for cross-sectional dependence in the test statistics (Mitchell \& Stafford, 2000). In the case of F-F three factor regression approach (calendar-time) we took the following steps: first, we used three different samples with (i) all cases, (ii) nonoverlapping $\operatorname{cases}^{47}$, and (iii) overlapping $\operatorname{cases}^{48}$ to isolate the effect of cross-sectional dependence (Lyon et al., 1999; Mitchell \& Stafford, 2000). Second, we used the weighted least square (WLS) procedure to account for acquisition activity weights in different months and to mitigate the potential heteroskedasticity problem (Andre et al., 2004; Franks et al., 1991) ${ }^{49}$.

Table 5.1 presents the results for BHAR analysis for all acquiring firms between 1993 and 2002. Six different benchmarks were used to calculate BHAR and to illustrate the differences in results with respect to benchmark choice. We also calculated equal and value weight BHAR to show the impact of the acquiring firms' size. As also

\footnotetext{
${ }^{47}$ If a firm makes acquisitions within three years of a previous acquisition, the cases were considered "overlapping" and deleted from this sample.

${ }^{48}$ Cases when a firm makes one or more acquisitions within three years of a previous acquisition.

${ }^{49}$ However, there was no significant difference in result whether or not we considered WLS methodology while using value weight returns. Further, Mitchell and Stafford (2000) have shown that WLS methodology is not efficient in mitigating the heteroskedasticity problem.
} 
demonstrated by Fama (1998), from Table 5.1, we see that long-term abnormal return results differ significantly with respect to our methodological and benchmark choice. A description of the six benchmarks used in BHAR analysis is presented in Table 5.1. For brevity, we have confined our discussion to BHAR6 (matching firm benchmark) with adjusted ' $t$ ' statistics. This scenario (i) considers the appropriate benchmark with size and price to book value adjusted matching firm return (Loughran \& Vijh, 1997), and (ii) accounts for skewness and cross-sectional dependence ${ }^{50}$. For both the equal weight BHAR (adj. t-stat is -0.88 ) and the value-weight BHAR (adj. t-stat is 0.01) we did not find any significant long-term abnormal return.

We found that BHAR6 results differ quite significantly from BHAR (1-5) results. BHAR (1-5) uses reference portfolios and the market indices as benchmarks. As pointed out by Barber and Lyon (1997), use of reference portfolios and the market indicies as benchmarks induces "rebalancing" and "skewness" biases in BHAR results. As a result, BHAR results with these benchmarks would produce incorrect results and are likely to show underperformance for acquiring firms even if there is no such underperformance. Further, reference portfolio and the market index benchmarks ignore size and book-tomarket value factors while comparing the returns. In addition, conventional BHAR methodology ignores the impact of cross-sectional dependence in test statistics. Table 5.1 demonstrates that BHAR (1-5) show significantly higher level of underperformance compared to BHAR6. As pointed out by Barber and Lyon (1997), use of a matching firm return as the benchmark in BHAR calculation (as done in BHAR6) eliminates

\footnotetext{
${ }^{50}$ The average cross-correlation coefficient value to be used in the cross-sectional dependence correction and the corresponding procedure are presented in Appendix $\mathbf{J}$.
} 
rebalancing bias. To correct for skewness bias and cross-sectional dependence bias

(Mitchell \& Stafford, 2000) we used adjusted ' $t$ ' statistics to check the significance of

BHAR results (see Appendix G for details).

\section{Table 5.1 Buy and Hold Abnormal Return (BHAR) Considering All Acquisition Cases (Overlapping and Non-overlapping Cases)}

"BHAR" is the buy and hold abnormal return based on the average difference in the aggregated (compounded) performance between the included stock and the benchmark over a 36-month period starting after the effective month of acquisition. Value weight BHAR is calculated based on the market value weight of the acquiring firm at the effective date of acquisition. Depending on the benchmark, six different BHARs are calculated. BHAR1 uses equal weight matching firms' portfolio return as the benchmark. BHAR2 uses the value weight of the matching firms' portfolio returns as the benchmark. Matching firms are the TSX firms that did not make any acquisitions over the 1992-2003 period. BHAR3 uses the TSX 300 index as the benchmark. BHAR4 and BHAR5 use equal weight and value weight CFMRC index returns respectively as the benchmark. BHAR6 uses individual matching firm returns as the benchmark ${ }^{51}$. statistics and adjusted t-statistics are reported. Adjusted t-statistics accounts for skewness and crosssectional dependence in stock returns (see Appendix G for details).

\begin{tabular}{|c|c|c|c|c|c|c|}
\hline & BHAR1 & BHAR2 & BHAR3 & BHAR4 & BHAR5 & BHAR6 \\
\hline \multicolumn{7}{|c|}{ 1. Equal weight BHAR } \\
\hline & $-1.20 * * *$ & $-0.76 * * *$ & $-0.29 *$ & $-0.71 * * *$ & $-0.33 *$ & -0.26 \\
\hline t-stat & -30.44 & -29.08 & -11.12 & -28.16 & -12.35 & -5.71 \\
\hline Adj. t-stat & -4.65 & -4.44 & -1.70 & -4.30 & -1.89 & -0.88 \\
\hline \multicolumn{7}{|c|}{ 2. Value weight $\mathrm{BHAR}$} \\
\hline & $-2.17 * * *$ & $-1.23 * * *$ & $-0.54 * * *$ & $-1.07 * * *$ & $-0.54 * * *$ & 0.00 \\
\hline t-stat & -65.11 & -70.17 & -39.76 & -68.52 & -39.93 & 0.07 \\
\hline Adj. t-stat & -9.94 & -10.71 & -6.07 & -10.46 & -6.10 & 0.01 \\
\hline
\end{tabular}

Table 5.2 presents the results for F-F three factor regression analyses with respect to equal-weight and value-weight monthly portfolio return of acquiring firms (with weighted least square technique). For the "all case" scenario, the equal-weight (EW) 3year acquirer portfolio exhibits significantly negative average abnormal returns: alpha = -

\footnotetext{
${ }^{51}$ In order to select a matching firm we followed a two-stage procedure. First, we found out the TSX firms that have not made any acquisition during 1992 to 2003. Second, we performed OLS regression considering all acquiring firms and matching firms. We regressed the firms' returns on equity on firm size and market to book value variables (Loughran \& Vijh, 1997). Matching firms were selected based on the nearest propensity score obtained by using the coefficients of firm size and price to book value factors.
} 
0.004 per month, with a t-statistics of -2.009 (Panel A), while the intercept in valueweight $(\mathrm{VW})$ regression is not significant: alpha $=0.004$ per month, with a $t$-statistics of 0.776 (Panel B).

It appears that small acquirers are more likely to under-perform in the post-event period. These findings are consistent with earlier results reported by Mitchell and Stafford (2000), Brav and Gompers (1997), and Andre et al., (2004). In order to check the robustness of the results and be able to contrast our results with earlier studies, further analysis was conducted based on deal size, as a number of studies have considered only specific deal sizes ${ }^{52}$.

Results are organized under three categories based on the deal size: (i) less than 10 million Can\$, (ii) 10 to 100 million Can\$, and (iii) more than 100 million Can\$. Except for EW 10 to 100 million (Panel A), we did not find any support for underperformance. As the relative deal size rather than the absolute deal size is a better indicator of the economic significance of a deal, subsequently, we performed similar analysis with relative deal size. The results are presented in Table 5.4, Panel I, and Table 5.6.

\footnotetext{
${ }^{52}$ For example, Andre et al. (2004) have included only the deal sizes with more than 10 million Can\$.
} 


\section{Table 5.2 FF 3-factor Regression with All Cases}

We used Fama French (F-F) three factor regression to detect abnormal returns. RMRF is the difference between monthly stock return portfolio and 91-day T-bill rate. SMB is the difference between the returns of small size firm portfolios and large size firm portfolios. HML is the difference between the returns of value firm portfolios and growth firm portfolios. Details of this model are presented in Appendix G. The number of cases (with long-run return data) used in the analysis to calculate equal-weight and value-weight returns were $1077,434,408$, and 235 for "all firm," "less than $10 \mathrm{~m}, " 10$ to $100 \mathrm{~m}$," and "more than $100 \mathrm{~m}$ " respectively. We used the weighted least square (WLS) technique in the case of value-weight portfolio analysis, in which the square root of the number of firms in each month is used as the weight in regression model. The "Alpha" value reported in the regression model indicates the monthly average abnormal return of the sample. Panel A presents the equal weight analysis results and Panel B presents the value weight (with WLS) analysis results. t-statistics and significance levels are reported for each factor.

Results are further organized into three categories based on deal size: (i) less than 10 million Can\$, (ii) 10 to 100 million Can\$, and (iii) more than 100 million Can\$.

Panel A. Equal Weight Calendar-Time Portfolio

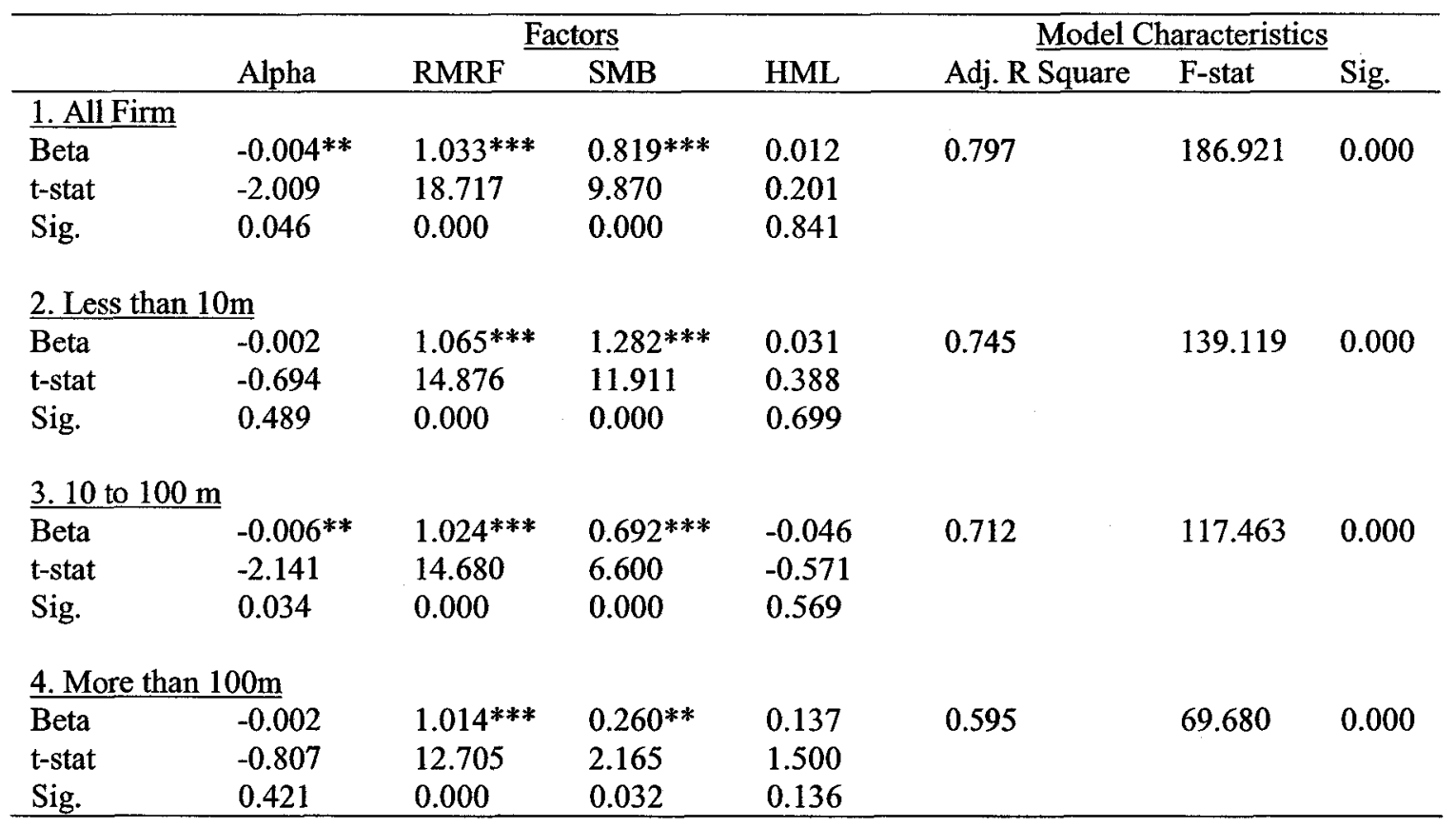


Panel B. Value Weight Calendar-Time Portfolio

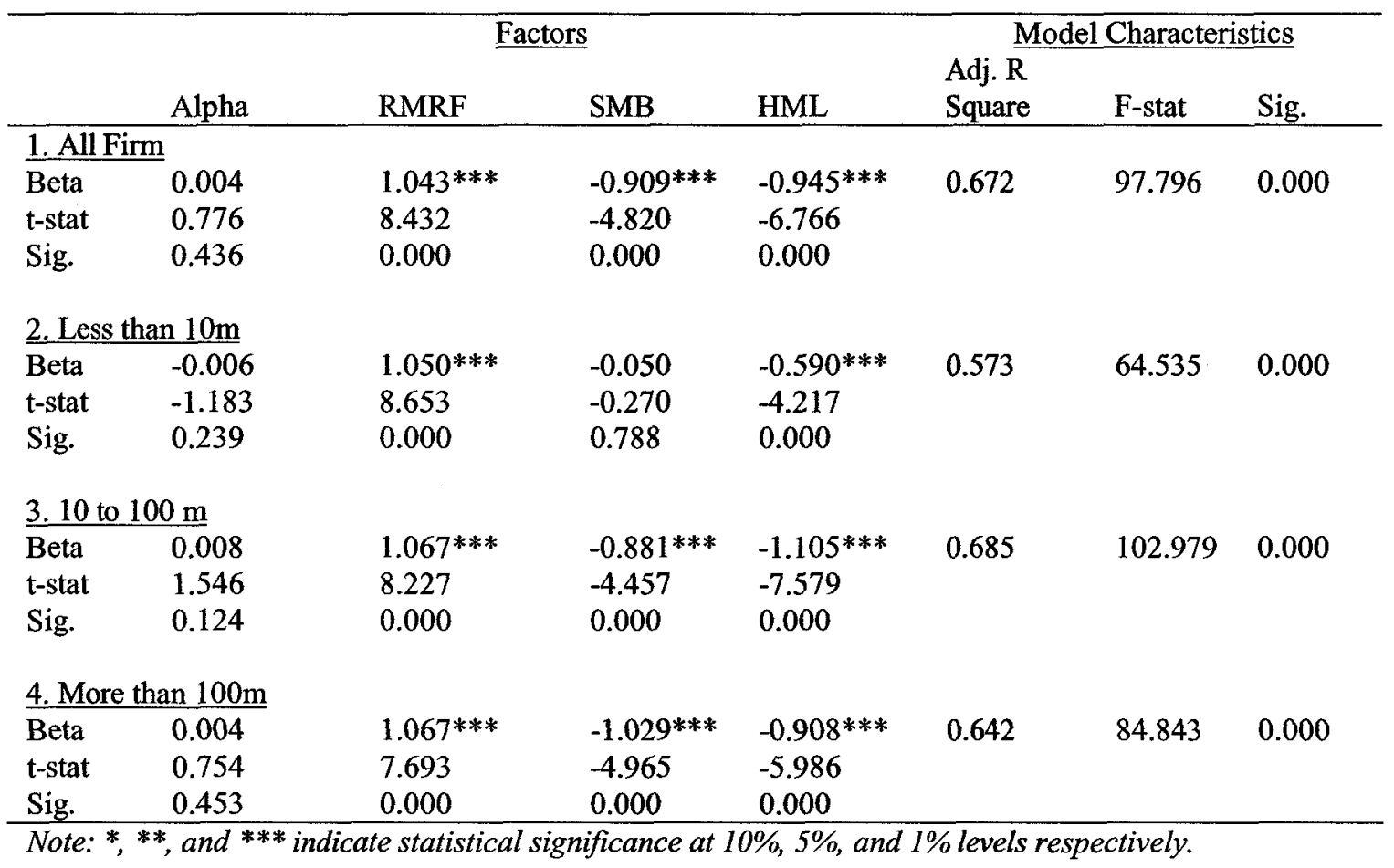

Subsequently, in order to eliminate the cross-sectional dependence problem arising from the overlapping acquisition events by the same firm, we present the F-F three factor regression results for non-overlapping cases (Table 5.3). These results are also contrasted with overlapping cases. Out of four scenarios (Panel A and Panel B), we observe underperformance only for EW overlapping cases (-0.006 monthly abnormal return with t-statistics of -2.235$)^{53}$. VW overlapping cases do not show any underperformance. Further, we find that VW non-overlapping cases show positive abnormal return.

53 We further investigated the differentiating characteristics of the non-overlapping and overlapping acquiring firms. We found that non-overlapping firms are smaller in size and have lower pre-event performance (return on equity and cash flow to total asset) compared to overlapping firms. Also, option pay to cash pay ratio for overlapping firms' CEOs is higher compared to that of non-overlapping firms' CEOs. These results are not surprising, as larger firms with better performances are likely to make more 
Table 5.3 FF 3-Factor Regression for Non-overlapping and Overlapping Cases

We use Fama French (F-F) three factor regression to detect abnormal return. RMRF is the difference between monthly stock return portfolio and 91-day T-bill rate. SMB is the difference between the returns of small size firm portfolios and large size firm portfolios. HML is the difference between the returns of value firm portfolios and growth firm portfolios. Details of this model are presented in Appendix G. The number of cases (with long-run return data) used in the analysis to calculate equal-weight and value-weight returns are 241 and 836 for "non-overlapping cases" and "overlapping cases" respectively. We used the weighted least square (WLS) technique in the case of value-weight portfolio analysis, in which the square root of the number of firms in each month is used as the weight in the regression model. The "Alpha" value reported in the regression model indicates the monthly average abnormal return of the sample. Panel A presents the equal weight analysis results and Panel B presents the value weight (with WLS) analysis results. t-statistics and significance levels are reported for each factor. If a firm makes acquisitions within three years of a previous acquisition, the events are considered "overlapping" cases. Otherwise, events are considered "nonoverlapping" cases.

Panel A. Equal Weight Calendar-Time Portfolio

\begin{tabular}{|c|c|c|c|c|c|c|c|}
\hline & \multicolumn{4}{|c|}{ Factors } & \multicolumn{3}{|c|}{ Model Characteristics } \\
\hline & Alpha & RMRF & SMB & HML & Adj. R Square & $\mathrm{F}$ & Sig. \\
\hline \multicolumn{8}{|c|}{ 1. Non-overlapping cases } \\
\hline Beta & 0.001 & $1.033^{* * *}$ & $1.155^{* * *}$ & -0.083 & 0.609 & 74.293 & 0.000 \\
\hline t-stat & 0.289 & 10.553 & 7.847 & -0.739 & & & \\
\hline Sig. & 0.773 & 0.000 & 0.000 & 0.461 & & & \\
\hline \multicolumn{8}{|c|}{ 2. Overlapping cases } \\
\hline Beta & $-0.006 * *$ & $1.022 * * *$ & $0.702^{* * *}$ & 0.035 & 0.728 & 127.454 & 0.000 \\
\hline t-stat & -2.235 & 15.894 & 7.261 & 0.476 & & & \\
\hline Sig. & 0.027 & 0.000 & 0.000 & 0.635 & & & \\
\hline
\end{tabular}

Panel B. Value Weight Calendar-Time Portfolio

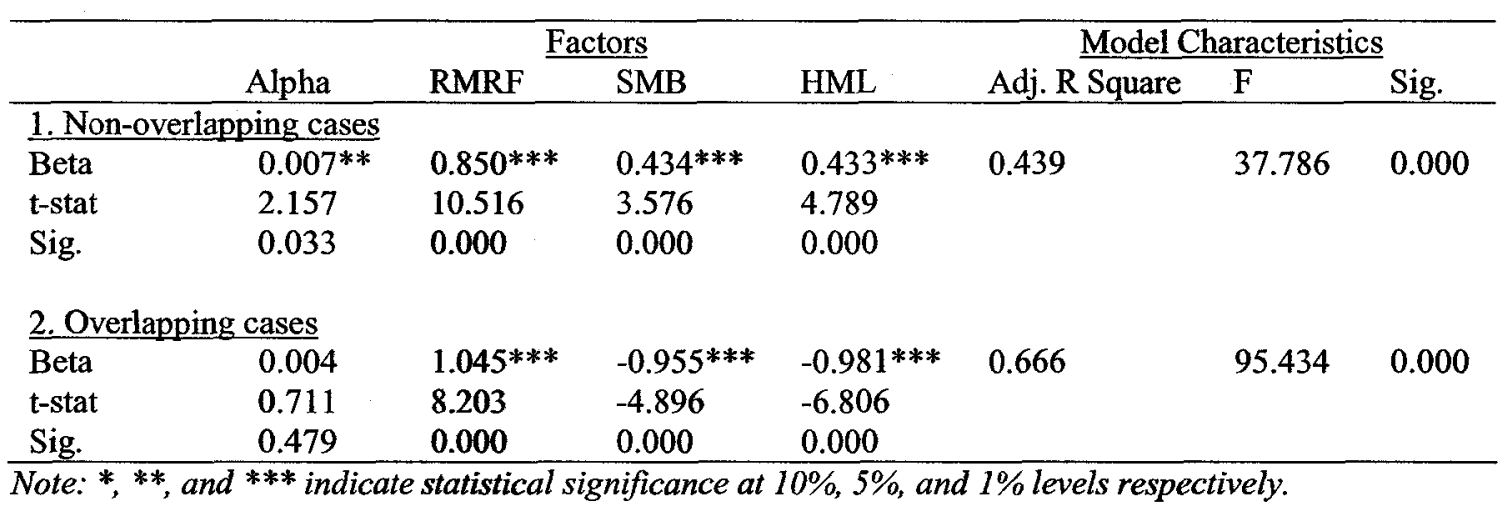

In summary, by using event-time approach and calendar-time approach, we did not find any strong support for long-term underperformance for acquiring firms in the post-event

acquisitions. Further, higher option pay will allow CEOs to take bigger risks. However, our findings also show that there is no significant difference between these two groups with respect to long-term BHAR and long-term operating performance (Appendix K). 
period $^{54}$ and we failed to reject hypothesis LT1. The results are similar to those previously documented by Mitchell and Stafford (2000) and are congruent with the market efficiency perspective (Fama, 1998; Kothari \& Brown, 2005).

\subsection{Factor Affecting Acquiring Firms' Long-term Performance}

In this section we report the impact of various deal specific factors and firm characteristics on long-term performance. Again, we used both the event-time approach (BHAR methodology) and the calendar-time approach (F-F three factor regression) in our analysis. With BHAR methodology, we present results from both univariate and multivariate analysis for the following factors to test our hypotheses presented in chapter 3: Tender or merger offer (hypothesis LT2), private or public target (hypothesis LT3), related or unrelated acquisition (hypothesis LT4), methods of payment (hypothesis LT5), growth or value firms (hypothesis LT6), board independence (hypothesis LT7), managerial ownership (hypothesis LT8), relative size (hypothesis LT9), and takeover premium (hypothesis LT10). For hypothesis LT10, we present only multivariate regression results. Subsequently, we used F-F three-factor regression methodology to investigate the same hypotheses.

\footnotetext{
${ }^{54}$ By using a Canadian sample, Andre et al. (2004) report long-term underperformance for acquiring firms for non-overlapping cases. However, their samples size is smaller (143) and they include financial firms in the analysis.
} 


\subsubsection{Event-time Approach: Univariate Analysis}

We used the event time approach and calculated buy and hold abnormal returns (BHAR) for each factor. As stated earlier, in our discussion we focused on the BHAR with matching firm return benchmark (BHAR6) and corresponding skewness and crosssectional dependence adjusted t-statistics. Results are presented in Table 5.4.

\section{Table 5.4 Factors Affecting Long-term Performance - Univariate Analysis}

"BHAR" is the buy and hold abnormal return based on the average difference in the aggregated (compounded) performance between the included stock and the benchmark over a 36-month period starting after the effective month of acquisition. Value weight BHAR is calculated based on the market value weight of the acquiring firm at the effective date of acquisition. Depending on the benchmark, six different BHARs are calculated. BHAR1 uses equal weight matching firms' returns as the benchmark. BHAR2 uses value weight matching firms' returns as the benchmark. Matching firms are the TSX firms that did not make any acquisition over the 1992-2003 period. BHAR3 uses the TSX 300 index as the benchmark. BHAR4 and BHAR5 use equal weight and value weight CFMRC index returns respectively as the benchmark. BHAR6 uses individual matching firm return as the benchmark. The Individual matching firm is selected based on the nearest propensity score with respect to firm size and price to book value. $t$ statistics and adjusted t-statistics are reported. Adjusted t-statistics accounts for skewness and crosssectional dependence in stock returns (see Appendix $\mathrm{G}$ for details). Results are reported for different factors in Panel A to Panel I. Mean differences and corresponding t-statistics are reported at the end of each panel for the related factors for all six BHARs. In order to avoid the extreme value (outlier) problem, the top 1\% and bottom $1 \%$ data of each variable included in the analysis are deleted. 


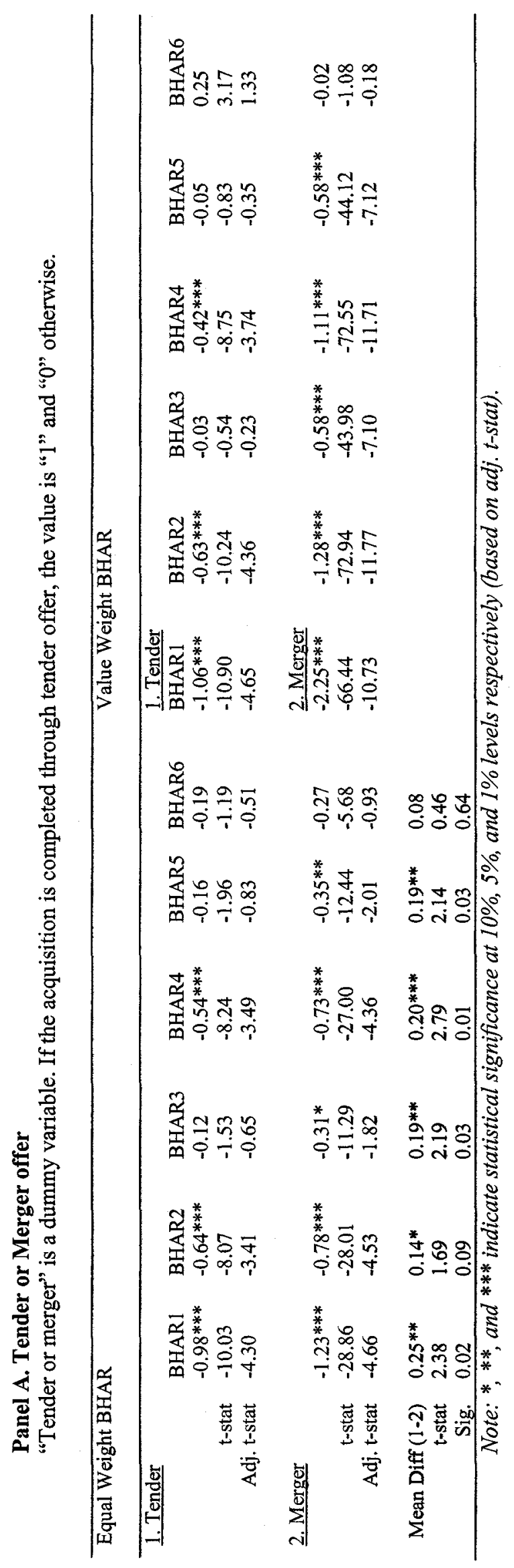




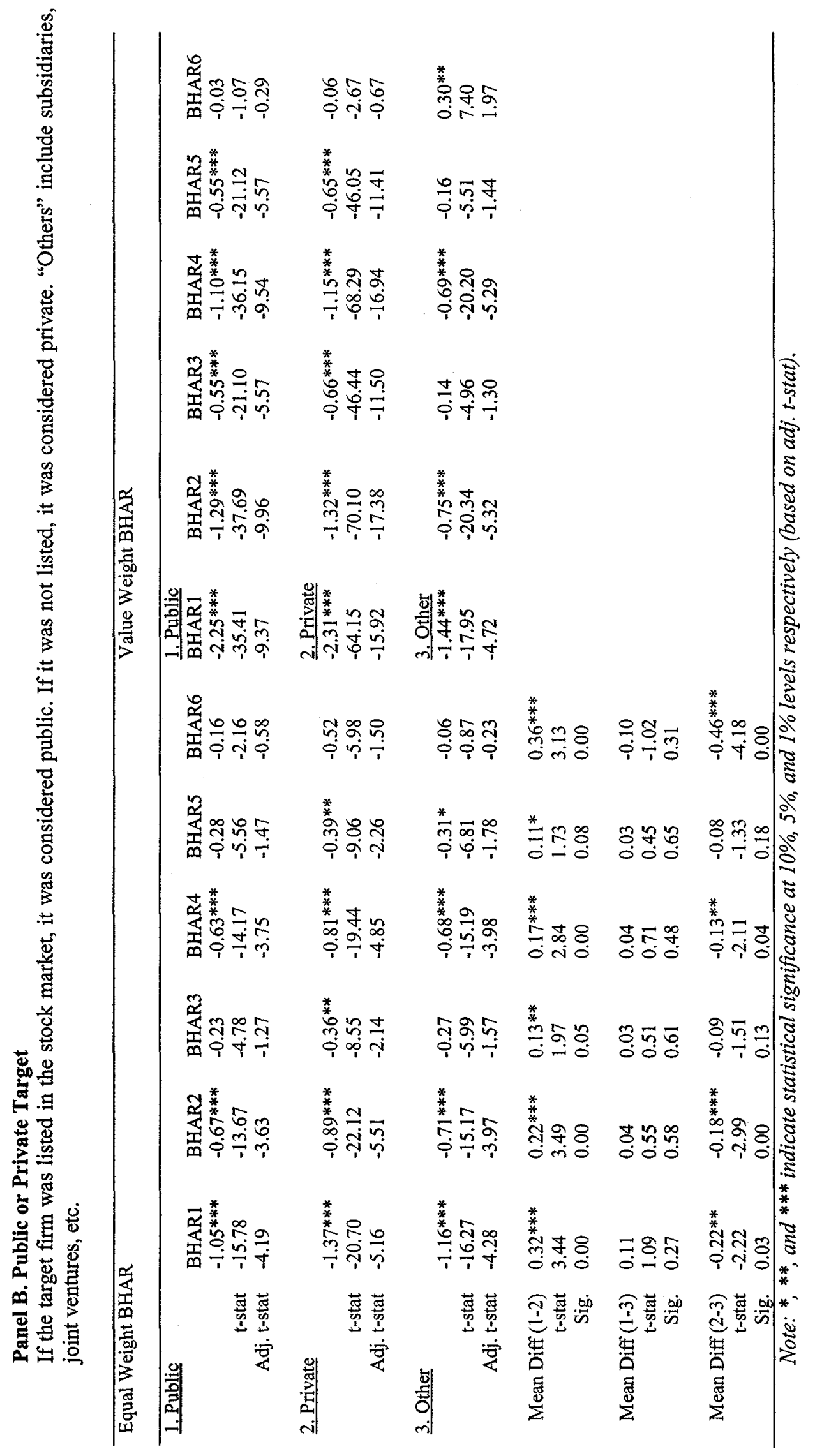


Panel C. Related or Unrelated Acquisitions

"Related/unrelated acquisition" is a dummy variable. For related acquisition, the value is " 1 " and " 0 " otherwise. It is determined based on the SIC code of the acquiring firm and the target firm. Two versions of this dummy variable are created based on: (i) 4-digit SIC code, and (ii) 2-digit SIC code. Here we report the results for 4-digit SIC code analysis only. Results are similar for 2-digit SIC code analysis.

\begin{tabular}{|c|c|c|c|c|c|c|c|c|c|c|c|c|}
\hline \multicolumn{7}{|c|}{ Equal Weight BHAR } & \multicolumn{6}{|c|}{ Value Weight BHAR } \\
\hline \multicolumn{7}{|c|}{ 1. Related 4 Digit } & \multicolumn{6}{|c|}{ 1. Related 4 Digit } \\
\hline & BHAR1 & BHAR2 & BHAR3 & BHAR4 & BHAR5 & BHAR6 & $\overline{\mathrm{BHAR} 1}$ & BHAR2 & BHAR3 & BHAR4 & BHAR5 & BHAR6 \\
\hline & $-1.08 * * *$ & $-0.69 * * *$ & -0.24 & $-0.65 * * *$ & -0.28 & -0.21 & $-1.45^{* * *}$ & -0.90 *** & $-0.33 * * *$ & $-0.79 * * *$ & $-0.35 * * *$ & 0.15 \\
\hline t-stat & -17.70 & -16.30 & -5.57 & -16.24 & -6.36 & -2.94 & -25.48 & -29.04 & -12.83 & -30.04 & -13.37 & 4.42 \\
\hline Adj. t-stat & -4.33 & -3.98 & -1.36 & -3.97 & -1.55 & -0.73 & -6.22 & -7.09 & -3.13 & -7.33 & -3.26 & 1.09 \\
\hline \multicolumn{7}{|c|}{ 2. Unrelated 4 Digit } & \multicolumn{6}{|c|}{ 2. Unrelated 4 Digit } \\
\hline & $-1.27 * * *$ & $-0.81 * * *$ & $-0.32 *$ & $-0.75 * * *$ & $-0.36 * *$ & -0.28 & $-2.33 * * *$ & $-1.30 * * *$ & $-0.59 * * *$ & $-1.13^{* * *}$ & $-0.58 * * *$ & -0.03 \\
\hline t-stat & -24.85 & -24.21 & -9.78 & -23.06 & -10.72 & -4.93 & -59.79 & -63.15 & -36.84 & -60.43 & -36.76 & -1.75 \\
\hline Adj. t-stat & -4.78 & -4.65 & -1.88 & -4.43 & -2.06 & -0.96 & -11.48 & -12.10 & -7.07 & -11.58 & -7.06 & -0.34 \\
\hline \multicolumn{13}{|l|}{ Mean Diff (1- } \\
\hline 2) & $0.19^{* *}$ & $0.12 * *$ & 0.08 & $0.11 * *$ & 0.08 & 0.07 & & & & & & \\
\hline t-stat & 2.36 & 2.28 & 1.54 & 2.06 & 1.49 & 0.78 & & & & & & \\
\hline Sig. & 0.02 & 0.02 & 0.12 & 0.04 & 0.14 & 0.44 & & & & & & \\
\hline
\end{tabular}


Panel D. Methods of Payment

Whether the acquisition is made through cash payment (category 1), stock payment (category 2), or mixed payment (category 3 ).

\begin{tabular}{|c|c|c|c|c|c|c|c|c|c|c|c|c|}
\hline \multicolumn{7}{|c|}{ Equal Weight BHAR } & \multicolumn{6}{|c|}{ Value Weight BHAR } \\
\hline \multicolumn{7}{|l|}{ 1. Cash Payment } & \multicolumn{6}{|c|}{ 1. Cash Payment } \\
\hline & BHAR1 & BHAR2 & BHAR3 & BHAR4 & BHAR5 & BHAR6 & BHAR1 & BHAR2 & BHAR3 & BHAR4 & BHAR5 & BHAR6 \\
\hline & $-1.15 * * *$ & $-0.74 * * *$ & -0.25 & $-0.70^{* * *}$ & $-0.29 *$ & -0.20 & $-1.75 * * *$ & $-1.00^{* * *}$ & $-0.38 * * *$ & $-0.87 * * *$ & $-0.38 * * *$ & 0.12 \\
\hline$t$-stat & -23.39 & -22.60 & -7.68 & -21.65 & -8.61 & -3.68 & -38.09 & -39.02 & -18.00 & -39.00 & -18.17 & 4.69 \\
\hline Adj. t-stat & -4.56 & -4.39 & -1.49 & -4.21 & -1.68 & -0.72 & -7.42 & -7.58 & -3.50 & -7.58 & -3.54 & 0.92 \\
\hline 2. Stock Payment & & & & & & & 2. Stock P & & & & & \\
\hline & $-1.32 * * *$ & $-0.84 * * *$ & $-0.40 * *$ & $-0.80 * * *$ & $-0.44 * *$ & $-0,45$ & $-2.78^{* * *}$ & $-1.51^{* * *}$ & $-0.73 * * *$ & $-1.33 * * *$ & $-0.73 * * *$ & $-0.10^{*}$ \\
\hline t-stat & -11.86 & -12.10 & -5.88 & -12.04 & -6.30 & -3.43 & -53.92 & -64.15 & -47.78 & -62.24 & -50.55 & -4.30 \\
\hline Adj. t-stat & -4.68 & -4.70 & -2.29 & -4.67 & -2.46 & -1.36 & -19.63 & -23.14 & -16.56 & -22.99 & -16.87 & -1.74 \\
\hline 3. Mixed & & & & & & & 3. Mixed & & & & & \\
\hline & $-1.25 * * *$ & $-0.78 * * *$ & $-0.31 *$ & $-0.71 * * *$ & $-0.34 *$ & -0.30 & $-2.24 * * *$ & $-1.33 * * *$ & $-0.62 * * *$ & $-1.13 * * *$ & $-0.61 * * *$ & -0.09 \\
\hline t-stat & -15.52 & -14.03 & -5.95 & -13.64 & -6.63 & -3.02 & -37.24 & -45.76 & -28.67 & -41.11 & -28.29 & -2.88 \\
\hline Adj. t-stat & -4.48 & -4.06 & -1.72 & -3.96 & -1.92 & -0.88 & -10.74 & -13.19 & -8.24 & -11.88 & -8.14 & -0.85 \\
\hline Mean Diff (1-2) & 0.17 & 0.10 & $0.15^{* *}$ & 0.11 & $0.15^{*}$ & $0.25 *$ & & & & & & \\
\hline t-stat & 1.38 & 1.30 & 1.96 & 1.43 & 1.92 & 1.76 & & & & & & \\
\hline Sig. & 0.17 & 0.20 & 0.05 & 0.15 & 0.06 & 0.08 & & & & & & \\
\hline Mean Diff (1-3) & 0.10 & 0.04 & 0.05 & 0.01 & 0.05 & 0.10 & & & & & & \\
\hline t-stat & 1.04 & 0.60 & 0.84 & 0.17 & 0.83 & 0.88 & & & & & & \\
\hline Sig. & 0.30 & 0.55 & 0.40 & 0.87 & 0.41 & 0.38 & & & & & & \\
\hline Mean Diff (2-3) & -0.07 & -0.06 & -0.10 & -0.10 & -0.10 & -0.15 & & & & & & \\
\hline t-stat & -0.51 & -0.68 & -1.14 & -1.13 & -1.12 & -0.91 & & & & & & \\
\hline Sig. & 0.61 & 0.50 & 0.26 & 0.26 & 0.26 & 0.36 & & & & & & \\
\hline
\end{tabular}


Panel E. Growth or Value Acquirers

"Growth or value" is a dummy variable. The value is " 1 " if the acquiring firm's price to book value ratio is greater than " 1 " and " 0 " otherwise.

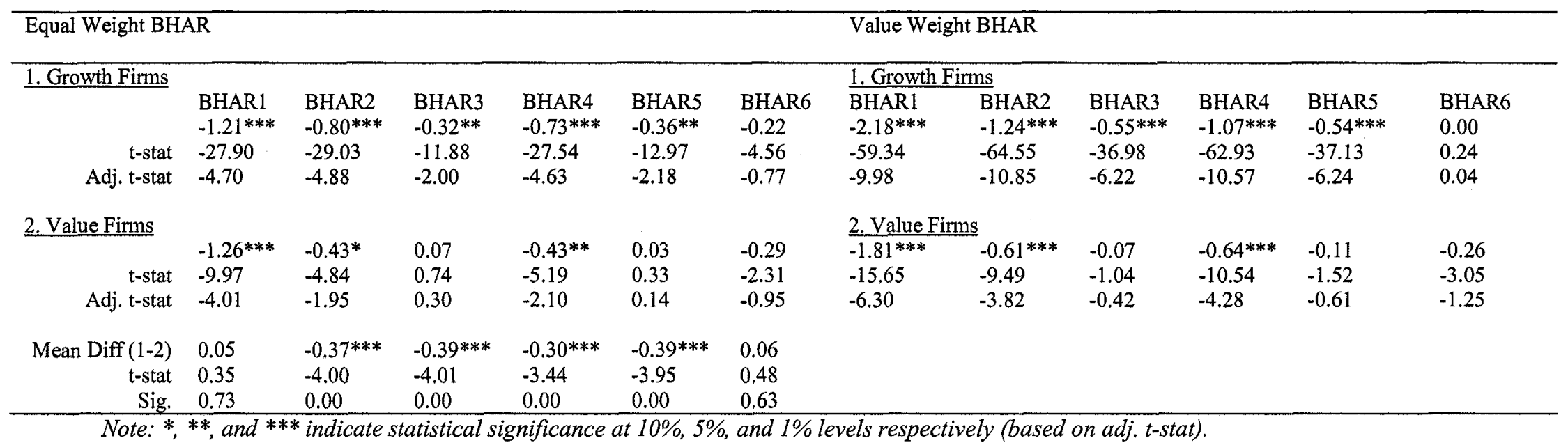


Panel F. Chair is Related or not

"Chair is related" is a dummy variable and is equal to " 1 " if the chair is related to management or the board, "0" otherwise. For example, if the CEO is also chair of the board, the dummy variable is equal to " 1 ".

\begin{tabular}{|c|c|c|c|c|c|c|c|c|c|c|c|c|}
\hline \multicolumn{7}{|c|}{ Equal Weight BHAR } & \multicolumn{6}{|c|}{ Value Weight BHAR } \\
\hline 1. Related & & & & & & & 1. Related & & & & & \\
\hline & BHAR1 & BHAR2 & BHAR3 & BHAR4 & BHAR5 & BHAR6 & BHAR1 & BHAR2 & BHAR3 & BHAR4 & BHAR5 & BHAR6 \\
\hline & $-1.58 * * *$ & $-0.87 * * *$ & -0.15 & $-0.67 * * *$ & -0.15 & -0.24 & $-1.48^{* * *}$ & $-1.09 * * *$ & $-0.31 * * *$ & $-0.87 * * *$ & $-0.29 * * *$ & 0.07 \\
\hline $\mathrm{t}$-stat & -21.43 & -20.45 & -3.70 & -16.78 & -3.62 & -3.12 & -30.05 & -30.66 & -11.10 & -29.10 & -10.45 & 1.64 \\
\hline Adj. t-stat & -5.39 & -5.15 & -0.93 & -4.20 & -0.91 & -0.79 & -7.57 & -7.72 & -2.78 & -7.29 & -2.62 & 0.41 \\
\hline 2. Unrelated & & & & & & & 2. Unrelated & & & & & \\
\hline & $-1.50 * * *$ & $-0.80 * * *$ & -0.10 & $-0.62 * * *$ & -0.10 & -0.05 & $-2.53 * * *$ & $-1.36 * * *$ & $-0.64 * * *$ & $-1.17 * * *$ & $-0.63 * * *$ & -0.02 \\
\hline t-stat & -16.60 & -13.49 & -1.73 & -11.50 & -1.80 & -0.61 & -44.73 & -54.30 & -30.96 & -46.05 & -30.58 & -1.37 \\
\hline Adj. t-stat & -5.34 & -4.29 & -0.55 & -3.66 & -0.57 & -0.20 & -14.21 & -16.95 & -9.67 & -14.43 & -9.55 & -0.44 \\
\hline Mean Diff (1-2) & -0.08 & -0.08 & -0.06 & -0.05 & -0.05 & $-0.20 *$ & & & & & & \\
\hline t-stat & -0.69 & -1.04 & -0.82 & -0.81 & -0.73 & -1.81 & & & & & & \\
\hline Sig. & 0.49 & 0.30 & 0.41 & 0.42 & 0.46 & 0.07 & & & & & & \\
\hline
\end{tabular}


Panel G. Board Independence

"Board independence" is a dummy variable. The value is " 1 " if majority of the board members are unrelated and " 0 " otherwise.

\begin{tabular}{|c|c|c|c|c|c|c|c|c|c|c|c|c|}
\hline \multicolumn{7}{|c|}{ Equal Weight BHAR } & \multicolumn{6}{|c|}{ Value Weight BHAR } \\
\hline \multicolumn{7}{|l|}{ 1. Independent } & \multicolumn{6}{|c|}{ 1. Independent } \\
\hline & BHAR1 & BHAR2 & BHAR3 & BHAR4 & BHAR5 & BHAR6 & BHAR1 & BHAR2 & BHAR3 & BHAR4 & BHAR5 & BHAR6 \\
\hline & $-1.52 * * *$ & $-0.85^{* * *}$ & -0.14 & $-0.65 * * *$ & -0.14 & -0.09 & $-2.38 * * *$ & $-1,36^{* * * *}$ & $-0.62 * * *$ & $-1.16 * * *$ & $-0.60 * * *$ & -0.05 \\
\hline t-stat & -23.98 & -21.76 & -3.72 & $-18,08$ & -3.72 & -1.54 & -57.16 & -70.10 & -38.57 & -62.75 & -37.79 & $-2,88$ \\
\hline Adj. t-stat & -5.32 & -4.82 & -0.82 & -3.99 & -0.82 & -0.34 & -12.65 & -15.49 & -8.49 & -13.82 & -8.32 & -0.64 \\
\hline \multicolumn{7}{|l|}{ 2. Dependent } & \multicolumn{6}{|c|}{ 2. Dependent } \\
\hline & $-1.68 * * *$ & $-0.84 * * *$ & -0.10 & $-0.66 * * *$ & -0.10 & -0.60 & $-1.52 * * *$ & $-0.64 * * *$ & 0.07 & $-0.46 * * *$ & 0.07 & $0.54 * * *$ \\
\hline Adj. t-stat & -5.68 & -4.70 & -0.55 & -3.90 & -0.54 & -1.55 & -6.43 & -7.93 & 0.91 & -4.88 & 0.95 & 3.11 \\
\hline Mean Diff (1-2) & 0.15 & -0.01 & -0.04 & 0.01 & -0.04 & $0.51 * * *$ & & & & & & \\
\hline t-stat & 1.05 & -0.08 & -0.43 & 0.09 & -0.44 & 2.74 & & & & & & \\
\hline Sig. & 0.30 & 0.93 & 0.66 & 0.92 & 0.66 & 0.01 & & & & & & \\
\hline
\end{tabular}




\section{Panel H. Managerial Ownership}

We used director ownership as a proxy for managerial ownership of the firm. Director ownership is the percentage of outstanding shares owned by all directors (including CEO) of the firm. Subsequently three categories are created for director ownership namely, for less than $5 \%, 5-25 \%$, and more than $25 \%$.

\begin{tabular}{|c|c|c|c|c|c|c|c|c|c|c|c|c|}
\hline \multicolumn{7}{|c|}{ Equal Weight BHAR } & \multicolumn{6}{|c|}{ Value Weight BHAR } \\
\hline \multicolumn{7}{|l|}{ 1. Less than $5 \%$} & \multicolumn{6}{|c|}{ 1. Less than $5 \%$} \\
\hline & BHAR1 & BHAR2 & BHAR3 & BHAR4 & BHAR5 & BHAR6 & $\overline{\mathrm{BHARI}}$ & BHAR2 & BHAR3 & BHAR4 & BHAR5 & BHAR6 \\
\hline & $-1.62 * * *$ & $-0.85 * * *$ & -0.14 & $-0.66^{* * *}$ & -0.14 & -0.09 & $-2.38 * * *$ & $-1.36^{* * *}$ & $-0.63^{* * *}$ & $-1.17 * * *$ & $-0.61 * * *$ & -0.05 \\
\hline $\mathrm{t}$-stat & -20.41 & -16.57 & -3.09 & -14.18 & -3.04 & -1.31 & -43.34 & -52.56 & -30.76 & -48.54 & -30.24 & -2.13 \\
\hline Adj. t-stat & -5.91 & -4.81 & -0.89 & -4.09 & -0.88 & -0.38 & -12.49 & -15.11 & -8.81 & -13.90 & -8.67 & -0.62 \\
\hline 2.5 to $25 \%$ & & & & & & & 2.5 to $25 \%$ & & & & & \\
\hline & $-1.51 * * *$ & $-0.90 * * *$ & -0.19 & $-0.70 * * *$ & -0.19 & -0.42 & $-1.57 * * *$ & $-0.88 * * *$ & -0.16 & $-0.68 * * *$ & -0.14 & -0.12 \\
\hline t-stat & -15.31 & -15.18 & -3.39 & -13.58 & -3.39 & -3.75 & -16.46 & -17.02 & -3.12 & -15.03 & -2.88 & -1.52 \\
\hline Adj. t-stat & -5.03 & -4.97 & -1.11 & -4.45 & -1.11 & -1.25 & -5.40 & -5.58 & -1.02 & -4.92 & -0.94 & -0.51 \\
\hline 3. More than $25 \%$ & & & & & & & 3. More th & $25 \%$ & & & & \\
\hline & $-1.44 * * *$ & $-0.86 * * *$ & -0.09 & $-0,62 * * *$ & -0.10 & -0.07 & $-1.61^{* * *}$ & $-0.71 * * *$ & 0.06 & $-0.48 * * *$ & 0.07 & $0.57 * * *$ \\
\hline t-stat & -12.69 & -12.57 & -1.40 & -9.08 & -1.41 & -0.62 & -18.94 & -25.72 & 2.89 & -15.67 & 3.32 & 11.67 \\
\hline Adj. t-stat & -4.69 & -4.58 & -0.51 & -3.30 & -0.51 & -0.23 & -7.00 & -9.45 & 1.05 & -5.74 & 1.21 & 4.15 \\
\hline Mean Diff (1-2) & -0.11 & 0.05 & 0.05 & 0.04 & 0.05 & $0.33 * * *$ & & & & & & \\
\hline t-stat & -0.86 & 0.61 & 0.65 & 0.50 & 0.67 & 2.48 & & & & & & \\
\hline Sig. & 0.39 & 0.54 & 0.52 & 0.61 & 0.50 & 0.01 & & & & & & \\
\hline Mean Diff (1-3) & -0.18 & 0.01 & -0.05 & -0.05 & -0.05 & -0.02 & & & & & & \\
\hline t-stat & -1.28 & 0.10 & -0.60 & -0.55 & -0.55 & -0.12 & & & & & & \\
\hline Sig. & 0.20 & 0.92 & 0.55 & 0.58 & 0.58 & 0.90 & & & & & & \\
\hline Mean Diff (2-3) & -0.07 & -0.04 & -0.10 & -0.08 & -0.09 & $=0.34^{* *}$ & & & & & & \\
\hline t-stat & -0.46 & -0.43 & -1.10 & -0.94 & -1.07 & -2.09 & & & & & & \\
\hline Sig. & 0.65 & 0.66 & 0.27 & 0.35 & 0.29 & 0.04 & & & & & & \\
\hline
\end{tabular}


Panel I. Relative Size

"Relative size" is the ratio of transaction value to market value of the acquiring firm's equity. Subsequently, three categories are created for relative size namely, for less than 5\%, 5-25\%, and more than $25 \%$.

\begin{tabular}{|c|c|c|c|c|c|c|c|c|c|c|c|c|}
\hline \multicolumn{7}{|c|}{ Equal Weight BHAR } & \multicolumn{6}{|c|}{ Value Weight BHAR } \\
\hline 1. Less than $5 \%$ & & & & & & & 1. Less than $5 \%$ & & & & & \\
\hline & BHAR1 & BHAR2 & BHAR3 & BHAR4 & BHAR5 & BHAR6 & $\overline{\text { BHAR1 }}$ & BHAR2 & BHAR3 & BHAR4 & BHAR5 & BHAR6 \\
\hline & $-1.27 * * *$ & $-0.81 * * *$ & $-0.31^{*}$ & $-0.74 * * *$ & $-0.35 * *$ & -0.26 & $-1.06 * * *$ & $-0.87 * * *$ & -0.20 & $-0.68 * * *$ & -0.20 & 0.16 \\
\hline t-stat & -19.76 & -20.00 & -7.93 & -19.17 & -8.81 & -3.80 & -20.30 & -21.55 & -6.70 & -20.80 & -6.75 & 4.13 \\
\hline Adj. t-stat & -4.72 & -4.75 & -1.89 & -4.56 & -2.10 & -0.91 & -4.85 & -5.12 & -1.60 & -4.95 & -1.61 & 0.99 \\
\hline 2.5 to $25 \%$ & & & & & & & 2.5 to $25 \%$ & & & & & \\
\hline & $-1.08 * * *$ & $-0.68 * * *$ & -0.22 & $-0.65 * * *$ & -0.26 & -0.15 & $-1.53 * * *$ & $-0.72 * * *$ & -0.18 & $-0.70^{* * *}$ & -0.21 & 0.18 \\
\hline t-stat & -14.98 & -14.28 & $-4,41$ & -14.40 & -5.05 & -1.81 & -19.91 & -21.24 & -5.38 & -22.85 & -6.03 & 3.65 \\
\hline Adj. t-stat & -4.02 & -3.83 & -1.18 & -3.86 & -1.35 & -0.49 & -5.34 & -5.70 & -1.44 & -6.12 & -1.62 & 0.98 \\
\hline 3. More than 25\% & & & & & & & 3. More than $25 \%$ & & & & & \\
\hline & $-1.16 * * *$ & $-0.74 * * *$ & -0.25 & $-0.64 * * *$ & -0.29 & -0.38 & $-1.40 * * *$ & $-0.84 * * *$ & $-0.45 * * *$ & $-0.98 * * *$ & $-0.45^{* * *}$ & $-0.49 *$ \\
\hline t-stat & -13.60 & -11.47 & -4.15 & -10.47 & -4.60 & -3.44 & -19.54 & -18.18 & -9.40 & -17.81 & -9.50 & -5.70 \\
\hline Adj. t-stat & -4.56 & -3.83 & -1.39 & -3.49 & -1.54 & -1.17 & -6.55 & -6.07 & -3.15 & -5.95 & -3.19 & -1.94 \\
\hline Mean Diff $(1-2)$ & $-0.19 * *$ & $-0.13^{* *}$ & -0.09 & -0.09 & -0.09 & -0.11 & & & & & & \\
\hline t-stat & -1.95 & -2.07 & -1.44 & -1.55 & -1.46 & -1.02 & & & & & & \\
\hline Sig. & 0.05 & 0.04 & 0.15 & 0.12 & 0.14 & 0.31 & & & & & & \\
\hline Mean Diff (1-3) & -0.11 & -0.07 & -0.06 & -0.10 & -0.06 & 0.12 & & & & & & \\
\hline t-stat & -1.08 & -0.89 & -0.77 & -1.43 & -0.86 & 0.92 & & & & & & \\
\hline Sig. & 0.28 & 0.37 & 0.44 & 0.15 & 0.39 & 0.36 & & & & & & \\
\hline Mean Diff $(2-3)$ & 0.07 & 0.06 & 0.03 & -0.01 & 0.03 & $0.23 *$ & & & & & & \\
\hline t-stat & 0.66 & 0.76 & 0.45 & -0.15 & 0.38 & 1.66 & & & & & & \\
\hline Sig. & 0.51 & 0.45 & 0.66 & 0.88 & 0.70 & 0.10 & & & & & & \\
\hline
\end{tabular}




\section{Tender or Merger Offer}

As Table 5.4, Panel A indicates, we found that there was no significant abnormal longterm return for tender or merger offer by looking at adjusted t-statistics (for matching firm BHAR). The mean difference between these two types of offers was also not significant.

\section{Public or Private Target}

From Table 5.4, Panel B, it is evident that there was no significant abnormal long-term return for public or private targets by looking at the adjusted t-statistics (for matching firm BHAR). However, the mean differences between these two types of targets reveal that the long-term abnormal returns for public targets were significantly higher than that of private targets (significance level of 0.000 ).

\section{Related or Unrelated Acquisitions}

From Table 5.4, Panel $\mathrm{C}$, we determined no significant abnormal long-term returns exist for related or unrelated acquisitions by looking at the adjusted t-statistics (for matching firm BHAR). The mean difference between these two types of acquisitions was also not significant.

\section{Methods of Payment}

From Table 5.4, Panel D, we found that in the case of value weight return, stock-financed deals under-performed in the long-run (10\% significance level). This result has further 
support from the mean difference analysis between cash financed deals and stock financed deals (significance level 0.08).

\section{Growth or Value Acquirers}

From Table 5.4, Panel E, we found that there was no significant abnormal long-term return for growth or value acquirers by looking at the adjusted t-statistics (for matching firm BHAR). The mean difference between these two types of acquirers was also not significant.

\section{Board Independence}

We used two variables to denote board independence: (i) whether or not Chair is related (results are presented in Table 5.4, Panel F), and (ii) whether or not majority of the board members are unrelated (results are presented in Table 5.4, Panel G). In the case of the "Chair related or not" variable, none of the equal weight (EW) or value weight (VW) matching firm BHARs were significant. However, the mean difference between related chair and unrelated chair events was negative and significant at 10\% level (significance level of 0.07) (Panel F). This shows that independent board chairs positively influence the acquisition decision. For the other proxy (panel G), we see that VW matching firm adjusted BHAR was significantly positive (at $1 \%$ level) for dependent boards ${ }^{55}$. It appears that boards with a majority of related directors tend to have a better insight about an acquisition target. However, the analysis with EW BHAR does not support this finding (panel G).

\footnotetext{
${ }^{55}$ Majority of the board members are related for a dependent board.
} 


\section{Managerial Ownership}

We used director ownership as a proxy for managerial ownership. From Table 5.4, Panel $\mathrm{H}$, we found that VW long-term abnormal returns for the "directors ownership greater than $25 \%$ " were significantly positive. This implies that higher level of director ownership aligns directors' interests with other shareholders' and results in better acquisition decisions.

\section{Relative Size}

From Table 5.4, Panel I, we found that the VW long-term abnormal returns for the "relative size greater than $25 \%$ " were negative at the $10 \%$ significance level. However, the mean differences in BHAR among three groups were not statistically significant. In sum, we did not find any strong evidence of long-term abnormal return in different relative deal size categories.

Again, as discussed earlier, we found that BHAR6 results differed significantly from other BHAR (1-5) results (Table 5.4, Panel A - I). BHAR (1-5) suffered from rebalancing and skewness biases and showed higher levels of underperformance, which was misleading in detecting long-term stock return performance.

\subsubsection{Event-time Approach: Multivariate Analysis}

To augment the univariate results and to investigate the confounding impact of various independent variables, Table 5.5 presents the results of the multivariate analysis. We used 
OLS regression to obtain our results. Results are presented separately for (i) deal specific variables and firm operating characteristics, and (ii) governance variables in Panel A and

Panel B respectively.

\section{Table 5.5 Factors Affecting Long-term Performance - Multivariate Analysis}

OLS regression of matching firm adjusted BHAR (BHAR6) on (i) deal specific variables and firm operating characteristics, and (ii) governance variables. Matching firm adjusted BHAR used individual matching firm return as the benchmark. Individual matching firm was selected based on the nearest propensity score with respect to firm size and price to book value.

Deal specific variables and firm operating characteristics: "Market value" was the year-end market value of firm's equity as reported in the Stock Guide Database. "Price to book value" was the ratio of the firms' market value to book value in the prior year. "Tender or merger" is a dummy variable. If the acquisition is completed through tender offer, the value is " 1 " and " 0 " otherwise. "Related/unrelated acquisition" is a dummy variable. For related acquisition, the value is " 1 " and " 0 " otherwise. It is determined based on the SIC code of acquiring firm and target firm. Two versions of this dummy variable are created, based on: (i) 4-digit SIC code, and (ii) 2-digit SIC code. "Target type" is a categorical variable outlining the nature of target firm. Three categories are created: (i) public target (pubprv1), (ii) private target (pubprv2), and (iii) other (subsidiaries, joint ventures etc.) (pubprv3). "Payment type" is a categorical variable outlining the nature of transaction payment mode. Three categories are created: (i) cash payment (paytype1), (ii) stock payment (paytype2), and (iii) mixed or other (paytype3). "Cross border target (CrsBd2 3)" is a dummy variable. The value is " 1 " if the target is from outside Canada or USA and " 0 " otherwise. "Target Premium" is the gain to the target shareholders due to takeover announcements. Two methods are used to proxy for "target premium". First, we use cumulative abnormal return for the target firm over "- 30 days to +30 days" to calculate target premium (Crawford \& Lechner, 1996) ${ }^{56}$. Second, we calculate target premium using offer price and pre-announcement stock price at "day -15 ", adjusting for market movement (St-Pierre, 1994) $)^{57}$. "Relative size" is the ratio of transaction value and market value of the acquiring firm's equity.

Governance variables: "Chair is related" is a dummy variable and is equal to "1" if the chair is related to management or the board, " 0 " otherwise. For example, if the CEO is also chair of the board, the dummy variable is equal to " 1 ". "Percentage of inside directors" is the ratio of related directors to total board size. "Blockholder ownership" is the percentage of outstanding shares owned by individuals or institutions other than the directors. If the blockholder ownership is less than $10 \%$, the input value for this variable is " 0 ". Subsequently, three categories are created for blockholder ownership, namely, for less than $10 \%, 10-25 \%$, and more than $25 \%$. "CEO ownership" is the percentage of outstanding shares owned by CEOs. Subsequently, three categories are created for CEO ownership, namely, for less than $5 \%, 5-25 \%$, and more than $25 \%$. "Director ownership" is the percentage of outstanding shares owned by all directors (including the CEO) of the firm. Subsequently, three categories are created for director ownership namely, for less than $5 \%, 5-25 \%$, and more than $25 \%$. t-statistics and corresponding significance levels are reported. We

\footnotetext{
${ }^{56}$ As presented by Crawford and Lechner (1996), there are a number of advantages for this approach: (i) target premium can be calculated for all publicly traded targets irrespective of payment type, (ii) it considers the wealth effect for target shareholders around the announcement date, and thus gives a broader view of target premium.

${ }^{57}$ Target premium $=\left(\left(\mathrm{OP}_{\mathrm{t}}-\mathrm{P}_{\mathrm{t}-15}\right) / \mathrm{P}_{\mathrm{t}-15}\right)-\left(\left(\mathrm{I}_{\mathrm{t}}-\mathrm{I}_{\mathrm{t}-15}\right) / \mathrm{I}_{\mathrm{t}-15}\right)$, where, $\mathrm{OP}_{\mathrm{t}}=$ Price offered for the target shares at the announcement date. $P_{t-15}$ is the market value of the target shares 15 days prior to the announcement date. $I_{t}$ and $I_{t-15}$ are the Index values at the announcement date and 15 days prior to the announcement date respectively. This approach is applicable only for cash offers.
} 
used dummy variables to control for "year" and "industry" effect. In order to avoid extreme value (outlier) problem, top $1 \%$ and bottom $1 \%$ data of each variable included in the analysis were deleted.

Panel A. Deal specific variables and firm operating characteristics

\begin{tabular}{|c|c|c|c|c|c|}
\hline & & Model 1 & Model 2 & Model 3 & Model 4 \\
\hline \multirow[t]{3}{*}{ (Constant) } & Beta & $-0.905 * *$ & $-1.094^{* * *}$ & $-1.057 * * *$ & -1.123 \\
\hline & t-stat & -2.508 & -3.326 & -3.214 & -0.814 \\
\hline & Sig. & 0.012 & 0.001 & 0.001 & 0.419 \\
\hline \multirow[t]{3}{*}{ Log of Market Value (LNMMVAL) } & Beta & $0.083^{* * *}$ & $0.091^{* * *}$ & $0.086^{* * *}$ & 0.048 \\
\hline & $t$-stat & 3.223 & 3.625 & 3.425 & 0.543 \\
\hline & Sig. & 0.001 & 0.000 & 0.001 & 0.589 \\
\hline Related/Unrelated acquisition & Beta & 0.045 & 0.053 & 0.046 & \\
\hline \multirow[t]{2}{*}{ (REL4DIG) } & t-stat & 0.524 & 0.619 & 0.538 & \\
\hline & Sig. & 0.600 & 0.536 & 0.591 & \\
\hline \multirow[t]{3}{*}{ Price to book value (PRBV1) } & Beta & 0.006 & 0.005 & 0.005 & \\
\hline & $t$-stat & 0.418 & 0.377 & 0.335 & \\
\hline & Sig. & 0.676 & 0.706 & 0.738 & \\
\hline \multirow[t]{3}{*}{ Payment type - cash (PAYTYPE1) } & Beta & -0.023 & 0.001 & 0.002 & \\
\hline & $t$-stat & -0.225 & 0.009 & 0.023 & \\
\hline & Sig. & 0.822 & 0.993 & 0.982 & \\
\hline \multirow[t]{3}{*}{ Payment type - stock (PAYTYPE2) } & Beta & -0.126 & -0.112 & -0.092 & \\
\hline & $t$-stat & -0.883 & -0.794 & -0.651 & \\
\hline & Sig. & 0.378 & 0.427 & 0.516 & \\
\hline \multirow[t]{3}{*}{ Target type - public (PUBPRV1) } & Beta & -0.051 & & & \\
\hline & t-stat & -0.490 & & & \\
\hline & Sig. & 0.625 & & & \\
\hline \multirow[t]{3}{*}{ Target type - private PUBPRV2 } & Beta & -0.142 & & & \\
\hline & t-stat & -1.370 & & & \\
\hline & Sig. & 0.171 & & & \\
\hline \multirow[t]{3}{*}{ Log of relative size (LNRELSZ1) } & Beta & $0.052 *$ & $0.058^{* *}$ & $0.058^{* *}$ & -0.080 \\
\hline & $t$-stat & 1.781 & 1.986 & 1.994 & -0.972 \\
\hline & Sig. & 0.075 & 0.047 & 0.047 & 0.335 \\
\hline \multirow[t]{3}{*}{ Tender/ Merger offer (TENMER) } & Beta & & 0.027 & 0.051 & \\
\hline & $t$-stat & & 0.201 & 0.383 & \\
\hline & Sig. & & 0.841 & 0.702 & \\
\hline \multirow[t]{3}{*}{ Cross border target (CRSBD2_3) } & Beta & & & $0.208^{* *}$ & \\
\hline & $t$-stat & & & 2.037 & \\
\hline & Sig. & & & 0.042 & \\
\hline \multirow[t]{3}{*}{ Target premium (PREMIUM1) } & Beta & & & & -0.086 \\
\hline & $t$-stat & & & & -0.262 \\
\hline & Sig. & & & & 0.794 \\
\hline R Square & & 0.043 & 0.041 & 0.045 & 0.136 \\
\hline Adjusted R Square & & 0.019 & 0.018 & 0.022 & -0.077 \\
\hline $\mathrm{F}$ & & 1.795 & 1.790 & 1.908 & 0.637 \\
\hline Sig. & & 0.016 & 0.018 & 0.008 & 0.841 \\
\hline $\mathrm{N}$ & & 866 & 866 & 866 & 82 \\
\hline
\end{tabular}

Note: $*{ }^{* *}$, and ${ }^{* * *}$ indicate statistical significance at $10 \%, 5 \%$, and $1 \%$ levels respectively. 
Panel B. Governance variables

\begin{tabular}{|c|c|c|c|}
\hline & & Model 1 & Model 2 \\
\hline \multirow{3}{*}{ (Constant) } & Beta & $-1.116^{* *}$ & $-1.017^{*}$ \\
\hline & $t$-stat & -2.251 & -1.934 \\
\hline & Sig. & 0.025 & 0.054 \\
\hline \multirow[t]{3}{*}{ Log of market value (LNMMVAL) } & Beta & $0.117 * * *$ & $0.111 * * *$ \\
\hline & t-stat & 3.423 & 3.142 \\
\hline & Sig. & 0.001 & 0.002 \\
\hline \multirow[t]{3}{*}{ Log of relative size (LNRELSZ1) } & Beta & $0.088 * *$ & $0.083 * *$ \\
\hline & $t$-stat & 2.370 & 2.242 \\
\hline & Sig. & 0.018 & 0.025 \\
\hline \multirow[t]{3}{*}{ Related/ unrelated acquisition (REL4DIG) } & Beta & -0.006 & 0.009 \\
\hline & $t$-stat & -0.050 & 0.076 \\
\hline & Sig. & 0.960 & 0.940 \\
\hline \multirow[t]{3}{*}{ Chair is related (CHRREL) } & Beta & -0.009 & -0.014 \\
\hline & $t$-stat & -0.071 & -0.116 \\
\hline & Sig. & 0.943 & 0.907 \\
\hline \multirow[t]{3}{*}{ Percentage of inside directors (PINDIR) } & Beta & -0.585 & $-0.658 *$ \\
\hline & $t$-stat & -1.540 & -1.686 \\
\hline & Sig. & 0.124 & 0.092 \\
\hline \multirow[t]{3}{*}{ Blockholder ownership (10 to $25 \%$ ) (BLKOWN2) } & Beta & 0.133 & 0.169 \\
\hline & $t$-stat & 0.760 & 0.962 \\
\hline & Sig. & 0.447 & 0.336 \\
\hline Blockholder ownership (more than $25 \%$ ) & Beta & -0.195 & -0.137 \\
\hline \multirow[t]{2}{*}{ BLKOWN3 } & $t$-stat & -1.195 & -0.803 \\
\hline & Sig. & 0.233 & 0.423 \\
\hline \multirow{3}{*}{ CEO ownership ( 5 to $25 \%$ ) (CEOOWN2) } & Beta & 0.120 & \\
\hline & $t$-stat & 0.820 & \\
\hline & Sig. & 0.412 & \\
\hline \multirow[t]{3}{*}{ CEO ownership (more than 25\%) (CEOOWN3) } & Beta & 0.047 & \\
\hline & $t$-stat & 0.280 & \\
\hline & Sig. & 0.780 & \\
\hline \multirow[t]{3}{*}{ Director ownership ( 5 to $25 \%$ ) (DIROWN2) } & Beta & & -0.084 \\
\hline & $t$-stat & & -0.576 \\
\hline & Sig. & & 0.565 \\
\hline \multirow[t]{3}{*}{ Director ownership (more than 25\%) (DIROWN3) } & Beta & & 0.195 \\
\hline & t-stat & & 1.154 \\
\hline & Sig. & & 0.249 \\
\hline \multicolumn{2}{|l|}{ R Square } & 0.063 & 0.067 \\
\hline \multicolumn{2}{|l|}{ Adjusted R Square } & 0.028 & 0.032 \\
\hline \multicolumn{2}{|l|}{$\mathbf{F}$} & 1.781 & 1.899 \\
\hline \multicolumn{2}{|l|}{ Sig. } & 0.025 & 0.014 \\
\hline \multicolumn{2}{|l|}{$\mathrm{N}$} & 495 & 497 \\
\hline
\end{tabular}




\section{Deal specific Variables and Firm Operating Characteristics}

Corresponding results are presented in Table 5.5, Panel A with the help of four regression models. As tender offers and target types are highly correlated, results for these variables are presented in separate models. Result for the "target premium" variable is reported separately in Model 4, as the inclusion of this variable reduces the sample size dramatically ${ }^{58}$. We found that only relative size had a significant positive impact on longterm performance among the hypothesized factors ${ }^{59}$ (significant at $5 \%$ level in Model 2 and 3). Two possible explanations for this observation are as follows: (i) acquisition of a relatively large target is likely to be a more important economic event for the acquirer than is the acquisition of a relatively small target (Eckbo et al., 1990) and higher relative size could bring in more synergy (positive effect), and (ii) management spends more time and effort in deciding on larger acquisition deals. The market recognizes this management effort and reacts positively for relatively larger acquisition deals. We have also tested the impact of cross border acquisition by using a dummy variable. If the target is from outside Canada and U.S., the value of the dummy variable is " 1 ", and " 0 " otherwise. The coefficient of this dummy variable is positive and significant at $5 \%$ level (Model 3). This implies that targets from outside Canada or U.S., benefits the acquiring firms with diversification effect and it is recognized by the market in the long-run.

\section{Governance Variables}

Corresponding results are presented in Table 5.5, Panel B) with the help of two regression models. Results for CEO ownership and directors' ownership are presented

\footnotetext{
${ }^{58}$ Target premium is calculated only for the publicly traded targets listed on Toronto Stock Exchange.

${ }^{59}$ However, one should view this result with caution. The dependent variable (BHAR6) used in the OLS regression do not account for cross-sectional dependence.
} 
separately in Model 1 and Model 2 respectively, as both variables act as a proxy for managerial ownership. None of the governance variables had a significant impact on long-term abnormal return performance. Only the percentage of inside directors was marginally significant at the $10 \%$ significance level. Overall, we do not get any consistent perspective, once we consider both univariate and multivariate results.

In summary, if we take an integrated perspective by considering univariate results and multivariate results, we do not find much evidence for long-term abnormal return in the post-event period. Multivariate analysis revealed significant results only for "relative size", and "cross border acquisition". We found that (i) relatively larger acquisition deals did better in the long-run, and (ii) targets from outside U.S. and Canada had positive impacts on long-term performance. We can see that results for "relative size" in univariate and multivariate analysis are quite different, which raises question about the robustness of the "relative size" result. Further, from the univariate analysis we found strong evidence of long-term positive abnormal returns for high level of managerial ownership $^{60}$.

Next, we tested the hypotheses using the calendar-time approach to check the robustness of the results.

\footnotetext{
${ }^{60}$ However, we did not find any significant result with multivariate analysis.
} 


\subsubsection{Calendar-time Approach: F-F Three Factor Model}

Table 5.6 presents alphas from F-F three factor regression models estimated over a threeyear period for various factors.

\section{Table 5.6 Long-term Abnormal Return for Various Factors Using F-F Three Factor Model}

We used Fama-French (F-F) three factor regression to detect abnormal return. Details of this model are presented in Appendix G. We used value-weight returns in regression models ${ }^{61}$. The"alpha" value reported in the regression model indicates the monthly average abnormal return of the sample. To test for differences in the returns for various factors, we regressed the differences in the returns of two portfolios on the F-F three factors (Andre et al., 2004). $t$-statistics and significance levels are reported for each factor. We used both "overlapping" and "non-overlapping" cases in the analysis ${ }^{62}$. Please refer to Table 5.5 for a detailed description of each variable (factor) used in the analysis.

\begin{tabular}{|c|c|c|c|c|c|}
\hline Factors & & Alpha & t-stat & Sig & Adj. R Sq \\
\hline \multirow[t]{3}{*}{ Tender or Merger } & Tender (1) & 0.005 & 1.081 & 0.282 & 0.443 \\
\hline & Merger (2) & 0.003 & 0.509 & 0.611 & 0.626 \\
\hline & $(1)-(2)$ & 0.002 & 0.444 & 0.658 & 0.263 \\
\hline \multirow[t]{3}{*}{ Target Type } & Public (1) & 0.005 & 1.031 & 0.304 & 0.620 \\
\hline & Private (2) & 0.003 & 0.345 & 0.731 & 0.494 \\
\hline & $(1)-(2)$ & 0.002 & 0.457 & 0.648 & 0.071 \\
\hline \multirow[t]{3}{*}{ Related / Unrelated Target } & Related (1) & $0.008 * * *$ & 2.707 & 0.008 & 0.680 \\
\hline & Unrelated (2) & 0.004 & 0.643 & 0.521 & 0.597 \\
\hline & $(1)-(2)$ & 0.004 & 0.736 & 0.463 & 0.250 \\
\hline \multirow[t]{3}{*}{ Payment type } & Cash (1) & 0.006 & 1.520 & 0.131 & 0.696 \\
\hline & Stock (2) & -0.003 & -0.269 & 0.788 & 0.348 \\
\hline & $(1)-(2)$ & 0.009 & 0.954 & 0.342 & 0.073 \\
\hline \multirow[t]{3}{*}{ Growth or value acquirer } & Growth (1) & 0.004 & 0.720 & 0.473 & 0.637 \\
\hline & Value (2) & -0.002 & -0.423 & 0.673 & 0.375 \\
\hline & $(1)-(2)$ & 0.006 & 0.954 & 0.342 & 0.451 \\
\hline \multirow[t]{3}{*}{ Board Independence } & Independent (1) & 0.008 & 0.915 & 0.363 & 0.547 \\
\hline & Dependent (2) & 0.006 & 1.124 & 0.264 & 0.326 \\
\hline & $(1)-(2)$ & 0.002 & 0.254 & 0.800 & 0.356 \\
\hline \multirow[t]{6}{*}{ Managerial ownership } & Less than $5 \%(1)$ & 0.007 & 0.782 & 0.436 & 0.544 \\
\hline & 5 to $25 \%(2)$ & $0.010 *$ & 1.901 & 0.061 & 0.538 \\
\hline & More than $25 \%$ (3) & 0.006 & 1.178 & 0.242 & 0.357 \\
\hline & $(1)-(2)$ & -0.003 & -0.236 & 0.814 & 0.200 \\
\hline & $(1)-(3)$ & 0.001 & 0.133 & 0.895 & 0.321 \\
\hline & $(2)-(3)$ & 0.004 & 0.574 & 0.567 & 0.069 \\
\hline \multirow[t]{4}{*}{ Relative Size } & Less than $5 \%$ (1) & 0.007 & 1.457 & 0.147 & 0.572 \\
\hline & 5 to $25 \%(2)$ & 0.003 & 1.058 & 0.292 & 0.531 \\
\hline & More than $25 \%$ (3) & 0.004 & 0.709 & 0.480 & 0.554 \\
\hline & $(1)-(2)$ & 0.003 & 0.615 & 0.539 & 0.279 \\
\hline
\end{tabular}




\begin{tabular}{llllll}
\hline Factors & & Alpha & t-stat & Sig & Adj. R Sq \\
\hline & $(1)-(3)$ & 0.004 & 0.892 & 0.374 & 0.051 \\
& $(2)-(3)$ & -0.001 & 0.084 & 0.933 & 0.300 \\
\hline
\end{tabular}

Note: $*, * *$ and ${ }^{* * *}$ indicate statistical significance at $10 \%, 5 \%$, and $1 \%$ levels respectively.

In general, by using F-F three-factor regression approach, we did not find any strong evidence of underperformance for the factors tested in the analysis (Table 5.6). Only related acquisitions showed significantly positive abnormal returns, although the difference in abnormal returns between related and unrelated acquisitions was not significant. Also, middle (5\% to $25 \%$ ) managerial ownership category showed weak evidence of positive performance (significant at 0.10 level). However, differences in abnormal returns with two other groups were statistically insignificant.

Once we combined the findings of event-time approach and calendar-time approach, we did not find any strong support for long-term abnormal returns for acquiring firms, which was robust across all methodologies (BHAR - univariate and multivariate, and F-F threefactor regression results). This observation leads us to the important conclusion that longterm performance results vary considerably with respect to methodological choices. For example, in the BHAR analysis (Table 5.1 and Table 5.4) we have seen that benchmark choices and adjustment for cross-sectional dependence can alter long-term performance results significantly. We also find that univariate and multivariate results differ considerably. Further, in many of the F-F regression results (Table 5.6), adjusted Rsquare values are too low to consider the "intercept" or the "alpha" value as a valid measure of abnormal return. 
Our findings suggest that acquiring firms' long-term abnormal performance results reported in earlier studies (such as Andre et al., 2004; Loughran \& Vijh, 1997) should be viewed with caution for the following reasons: (i) investigations are generally carried out using one of the two approaches (event-time or calendar-time) and various adjustments discussed earlier in this chapter with respect to event-time and calendar-time approach are not considered, (ii) in case of the investigation of several deal specific, firm specific, and governance factors only univariate results are presented, which ignore the confounding effects of dependent variables, and finally, (iii) there are still controversies surrounding the long-term performance methodologies that may distort empirical results. For example, it is argued that the BHAR method lacks statistical power (Kothari \& Warner, 2005), and that the Fama-French three-factor approach suffers from model specification problems ${ }^{63}$. Therefore, "whether the apparent abnormal returns (as reported in some studies) are due to mispricing, or simply the results of measurement problems, is a contentious and unresolved issue among financial economists" (Kothari \& Warner, 2005, p. 23).

In sum, we do not find any strong evidence to reject any of our long-term performance hypotheses. A summary of the results with respect to each hypothesis is presented in Table 5.7.

\footnotetext{
${ }^{63}$ If the factors used in the model cannot explain the variation in stock returns fully, the validity of considering "alpha" or "intercept" as a measure of abnormal return is questionable. In other words, to validate the abnormal return results of the Fama-French three-factor approach (or similar Jensen alpha approach), the model should show a very high level of R-square value.
} 
Table 5.7 Summary of the Long-term Stock Return Performance Hypotheses Test Results

\begin{tabular}{|c|c|c|}
\hline Issue & Long Term Performance & Results \\
\hline $\begin{array}{l}\text { Overall } \\
\text { Performance }\end{array}$ & $\begin{array}{l}\text { Hypothesis LT1: On an aggregate basis, there is } \\
\text { no significant long-term under-performance in } \\
\text { terms of stock return for the acquiring firms. }\end{array}$ & Supported (fail to reject). \\
\hline $\begin{array}{l}\text { Tender or } \\
\text { Merger offer }\end{array}$ & $\begin{array}{l}\text { Hypothesis LT2: There will be no significant } \\
\text { long-term abnormal performance for the acquiring } \\
\text { firm. }\end{array}$ & Supported (fail to reject). \\
\hline $\begin{array}{l}\text { Private or } \\
\text { Public Target }\end{array}$ & $\begin{array}{l}\text { Hypothesis LT3: There will be no significant } \\
\text { long-term abnormal performance for the acquiring } \\
\text { firm. }\end{array}$ & Supported (fail to reject) \\
\hline $\begin{array}{l}\text { Related or } \\
\text { unrelated } \\
\text { Acquisition }\end{array}$ & $\begin{array}{l}\text { Hypothesis LT4: There will be no significant } \\
\text { long-term abnormal performance for the acquiring } \\
\text { firm. }\end{array}$ & Supported (fail to reject). \\
\hline $\begin{array}{l}\text { Methods of } \\
\text { Payment }\end{array}$ & $\begin{array}{l}\text { Hypothesis LT5: There will be no significant } \\
\text { long-term abnormal performance for the acquiring } \\
\text { firm. }\end{array}$ & Supported (fail to reject). \\
\hline $\begin{array}{l}\text { Growth or } \\
\text { Value Firms }\end{array}$ & $\begin{array}{l}\text { Hypothesis LT6: There will be no significant } \\
\text { long-term abnormal performance for the acquiring } \\
\text { firm. }\end{array}$ & Supported (fail to reject). \\
\hline $\begin{array}{l}\text { Board } \\
\text { independence }\end{array}$ & $\begin{array}{l}\text { Hypothesis LT7: There will be no significant } \\
\text { long-term abnormal performance for the acquiring } \\
\text { firm. }\end{array}$ & Supported (fail to reject) \\
\hline $\begin{array}{l}\text { Managerial } \\
\text { Ownership }\end{array}$ & $\begin{array}{l}\text { Hypothesis LT8: There will be no significant } \\
\text { long-term abnormal performance for the acquiring } \\
\text { firm. }\end{array}$ & Supported (fail to reject). \\
\hline Relative Size & $\begin{array}{l}\text { Hypothesis LT9: There will be no significant } \\
\text { long-term abnormal performance for the acquiring } \\
\text { firm. }\end{array}$ & Supported (fail to reject) \\
\hline $\begin{array}{l}\text { Takeover } \\
\text { Premium }\end{array}$ & $\begin{array}{l}\text { Hypothesis LT10: There will be no significant } \\
\text { long-term abnormal performance for the acquiring } \\
\text { firm. }\end{array}$ & Supported (fail to reject). \\
\hline
\end{tabular}




\section{CHAPTER 6: RESULTS: LONG-TERM OPERATING PERFORMANCE}

In this chapter, we describe the results for long-term operating performance subsequent to an acquisition. We first describe the results for pre- and post-acquisition operating performance and investigate the differences between pre- and post-acquisition operating performance. Second, we investigate the relationship among long-term operating performance, long-term stock return performance and short-term abnormal returns pertaining to an acquisition decision.

\subsection{Pre- and Post-acquisition Operating Performance}

In this section we present the results for pre- and post-acquisition operating performance. As discussed earlier in chapter 3 , we used both industry adjusted operating performance and matching firm adjusted operating performance. The steps followed in selecting a matching firm are outlined in chapter 3 (section 3.3.3). As suggested by Healy et al., (1992) we used both the "intercept" approach and the mean comparison approach to detect differences in pre- and post-acquisition operating performance. Further, we carried out long-term operating performance analyses for different relative deal size categories (less than $5 \%, 5 \%$ to $25 \%$, and more than $25 \%$ ) as relative deal size is likely to impact the results of operating performance.

Table 6.1 presents the univariate results for both (i) industry adjusted and (ii) matching firm adjusted operating performance. We used cash flow to total assets as a proxy for 
operating performance (Ghosh, 2001; Healy et al., 1992). We found significant improvements in "acquiring firms" operating performance while considering industry adjusted pre- and post-acquisition operating performance (mean difference is 0.013 and significance level is 0.001 ). However, we did not see any significant difference in preand post-acquisition performance once we considered matching firm adjusted operating performance (mean difference is -0.006 and the significance level is 0.40 ). These results are similar to that of Ghosh (2001) and Healy et al. (1992).

\section{Table 6.1 Operating Performance (Cash Flow to Total Assets) for Pre- and Post- Merger Period}

"Industry adjusted cash flow to total asset" is the average difference in the operating performance (cash flow to total asset) between the acquiring firm and industry average for a given year relative to the acquisition year. "Industry adjusted post average cash flow to total asset" is the average of "Industry adjusted cash flow to total asset" for post acquisition period (year $+1,+2$ and +3 ). "Industry adjusted pre average cash flow to total asset" is the average of "Industry adjusted cash flow to total asset" for pre acquisition period (year $-1,-2$ and -3 )." Industry adjusted post and pre difference" is the average of the difference between "Industry adjusted post average cash flow to total asset" and "Industry adjusted pre average cash flow to total asset". "Matching firm adjusted cash flow to total asset" is the average difference in the operating performance (cash flow to total asset) between the acquiring firm and matching firm for a given year relative to the acquisition year. The "Individual marching firm" was selected based on the nearest propensity score with respect to firm size and price to book value. "Matching adjusted post average cash flow to total asset" is the average of "matching firm adjusted cash flow to total asset" for post acquisition period (year $+1,+2$ and +3 ). "Matching adjusted pre average cash flow to total asset" is the average of "Matching firm adjusted cash flow to total asset" for the pre-acquisition period (year -1, -2 and 3). "Matching firm adjusted post and pre difference" is the average of the difference between "Matching adjusted post average cash flow to total asset" and "Matching adjusted pre average cash flow to total asset". t-statistics and significance level are reported for each mean difference. In case of multiple acquisitions by a firm in any year, only one event was considered in the analysis. All operating performance variables are expressed in decimals. 


\begin{tabular}{|c|c|c|c|c|c|c|}
\hline \multirow[t]{2}{*}{$\begin{array}{c}\text { Year Relative to } \\
\text { M\&A }\end{array}$} & \multicolumn{3}{|c|}{$\begin{array}{l}\text { Industry adjusted cash flow } \\
\text { to total asset } \\
\text { (Acquiring firm - Industry Avg.) }\end{array}$} & \multicolumn{3}{|c|}{$\begin{array}{l}\text { Matching firm adjusted cash flow to } \\
\text { total asset } \\
\text { (Acquiring firm - Matching firm) }\end{array}$} \\
\hline & Mean & $\mathrm{t}$-stat & Sig, & Mean & t-stat & Sig, \\
\hline 3 & $0.046^{* * *}$ & 7.113 & 0.000 & $0.030 * * *$ & 3.109 & 0.002 \\
\hline 2 & $0.046^{* * *}$ & 9.528 & 0.000 & $0.048 * * *$ & 5.465 & 0.000 \\
\hline 1 & $0.047^{* * *}$ & 9.758 & 0.000 & $0.051 * * *$ & 5.506 & 0.000 \\
\hline-1 & $0.040^{* * *}$ & 8.988 & 0.000 & $0.053 * * *$ & 7.750 & 0.000 \\
\hline-2 & $0.031 * * *$ & 6.448 & 0.000 & $0.048 * * *$ & 5.863 & 0.000 \\
\hline-3 & $0.034 * * *$ & 6.673 & 0.000 & $0.057 * * *$ & 6.440 & 0.000 \\
\hline $\begin{array}{l}\text { Post Average: } \\
\text { mean of years } 3 \text {, } \\
2 \text {, and } 1\end{array}$ & $0.047^{* * *}$ & 11.033 & 0.000 & $0.045^{* * *}$ & 5.801 & 0.000 \\
\hline $\begin{array}{l}\text { Pre Average: } \\
\text { mean of years }-3 \text {, } \\
-2 \text {, and }-1\end{array}$ & $0.034 * * *$ & 8.684 & 0.000 & $0.051 * * *$ & 7.911 & 0.000 \\
\hline $\begin{array}{l}\text { (Post - Pre) } \\
\text { Difference }\end{array}$ & $0.013^{* * *}$ & 3.379 & 0.001 & -0.006 & -0.834 & 0.404 \\
\hline
\end{tabular}

Note (1): ${ }^{* * *}$, and ${ }^{* * *}$ indicate statistical significance at $10 \%, 5 \%$, and $1 \%$ levels respectively.

(2): We obtained similar results for the median values.

Subsequently, we investigated the results from the "intercept" approach proposed by Healy et al. (1992) to investigate the change in operating performance around event years. In this approach, we used the following cross-sectional regression and obtained the intercept from the model. This intercept is the measure of abnormal benchmark adjusted operating performance.

\section{Benchmark adjusted post average cash flow to total asset $=$ Intercept + beta ${ }^{*}$ Benchmark adjusted pre average cash flow to total asset}

A positive and significant value for the intercept would mean an improvement in operating performance in post event period over pre event period. We used the industry average operating performance and the matching firm operating performance as benchmarks. Results are presented in Table 6.2 . 


\section{Table 6.2 Regression on Pre-merger Performance}

Panel A. Industry adjusted cash flow to total asset

The dependent variable is the "Industry adjusted post average cash flow to total asset" (IPOSTAVG). "Industry adjusted post average cash flow to total asset" is the average of "Industry adjusted cash flow to total asset" for post acquisition period (year $+1,+2$ and +3 ). The independent variable is the "Industry adjusted pre average cash flow to total asset" (IPREAVG). "Industry adjusted pre average cash flow to total asset" is the average of "Industry adjusted cash flow to total asset" for the pre-acquisition period (year -1, 2 and -3). "Industry adjusted cash flow to total asset" is the average difference in the operating performance (cash flow to total asset) between the acquiring firm and the industry average for a given year relative to the acquisition year. "Relative size" is the ratio of transaction value and market value of the acquiring firm's equity. Subsequently, three categories are created for director ownership namely, for less than 5\%, 5-25\%, and more than $25 \%$. In case of multiple acquisitions by a firm in any year, only one event is considered in the analysis.

\begin{tabular}{|c|c|c|c|c|c|c|}
\hline & (Intercept) & IPREAVG & R Square & $\begin{array}{l}\text { Adj. } \\
\text { R Square }\end{array}$ & F-stat & Sig. \\
\hline \multicolumn{7}{|c|}{ 1. All Cases $(\mathrm{N}=671)$} \\
\hline Beta & $0.027 * * *$ & $0.582 * * *$ & 0.280 & 0.279 & 260.320 & 0.000 \\
\hline t-stat & 7.187 & 16.134 & & & & \\
\hline Sig. & 0.000 & 0.000 & & & & \\
\hline \multicolumn{7}{|c|}{ 2. Less than $5 \%(\mathrm{~N}=262)$} \\
\hline Beta & $0.025 * * *$ & $0.763 * * *$ & 0.429 & 0.426 & 195.022 & 0.000 \\
\hline t-stat & 4.129 & 13.965 & & & & \\
\hline Sig. & 0.000 & 0.000 & & & & \\
\hline \multicolumn{7}{|c|}{$3.5 \%$ to $25 \%(\mathrm{~N}=210)$} \\
\hline Beta & $0.019 * * *$ & $0.551 * * *$ & 0.245 & 0.241 & 67.330 & 0.000 \\
\hline t-stat & 3.005 & 8.205 & & & & \\
\hline Sig. & 0.003 & 0.000 & & & & \\
\hline \multicolumn{7}{|c|}{ 4. More than $25 \%(N=139)$} \\
\hline Beta & $0.051^{* * *}$ & $0.437 * * *$ & 0.181 & 0.175 & 30.248 & 0.000 \\
\hline t-stat & 5.821 & 5.500 & & & & \\
\hline Sig. & 0.000 & 0.000 & & 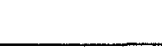 & & \\
\hline
\end{tabular}

(2): We obtained similar results for the median values. 
Panel B. Matching firm adjusted cash flow to total asset

The dependent variable is the "Matching adjusted post average cash flow to total asset" (MPOSTAVG). "Matching adjusted post average cash flow to total asset" is the average of "matching firm adjusted cash flow to total asset" for post acquisition period (year $+1,+2$ and +3 ). Independent variable is the "Matching adjusted pre-average cash flow to total asset" (MPREAVG). "Matching adjusted pre average cash flow to total asset" is the average of "Matching firm adjusted cash flow to total asset" for the pre acquisition period (year -1, -2 and -3). "Matching firm adjusted cash flow to total asset" is the average difference in the operating performance (cash flow to total asset) between the acquiring firm and matching firm for a given year relative to the acquisition year. "Relative size" is the ratio of transaction value and market value of the acquiring firm's equity. Subsequently three categories are created for director ownership namely, for less than $5 \%, 5-25 \%$, and more than $25 \%$. In case of multiple acquisitions by a firm in any year, only one event is considered in the analysis.

\begin{tabular}{|c|c|c|c|c|c|c|}
\hline & (Intercept) & MPREAVG & R Square & $\begin{array}{l}\text { Adj. R } \\
\text { Square }\end{array}$ & F-stat & Sig. \\
\hline \multicolumn{7}{|c|}{ 1. All Cases $(\mathrm{N}=623)$} \\
\hline Beta & $0.012 *$ & $0.659 * * *$ & 0.297 & 0.295 & 261.877 & 0.000 \\
\hline t-stat & 1.694 & 16.183 & & & & \\
\hline Sig. & 0.091 & 0.000 & & & & \\
\hline \multicolumn{7}{|c|}{ 2. Less than $5 \%(\mathrm{~N}=241)$} \\
\hline Beta & 0.010 & $0.673 * * *$ & 0.322 & 0.319 & 113.510 & 0.000 \\
\hline t-stat & 0.932 & 10.654 & & & & \\
\hline Sig. & 0.352 & 0.000 & & & & \\
\hline \multicolumn{7}{|c|}{$3.5 \%$ to $25 \%(\mathrm{~N}=198)$} \\
\hline Beta & 0.007 & $0.857 * * *$ & 0.349 & 0.346 & 105.001 & 0.000 \\
\hline t-stat & 0.522 & 10.247 & & & & \\
\hline Sig. & 0.602 & 0.000 & & & & \\
\hline \multicolumn{7}{|c|}{ 4. More than $25 \%(\mathrm{~N}=133)$} \\
\hline$\overline{\text { Beta }}$ & $0.027 * *$ & $0.598 * * *$ & 0.369 & 0.364 & 76.599 & 0.000 \\
\hline t-stat & 2.132 & 8.752 & & & & \\
\hline Sig. & 0.035 & 0.000 & & & & \\
\hline
\end{tabular}

As displayed in Table 6.2, the results are similar in univariate analysis and the "intercept" approach. We found significant abnormal returns in the case of industry adjusted operating performance for all cases (Panel A: intercept $=0.027$, significance level $=$ 0.000 ), and three categories of relative sizes. However, as discussed earlier, results from the industry adjusted operating performance analysis could be biased. In the case of the matching firm adjusted operating performance, the intercept was significant only at $9.1 \%$ level for all case scenario (Panel B: intercept $=0.012$, significance level $=0.091$ ). 
Interestingly, we further found that in the case of a large relative size group, there was a significant level of improvement in the long-term operating performance following an acquisition (Panel B: intercept $=0.027$, significance level 0.035). This is consistent with the viewpoint that only relatively larger deals are economically significant enough to impact the long-term operating performance of an acquiring firm. As reported earlier in chapter 4, takeover premiums are significantly higher for relatively larger deals, indicating that the market accounts for long-term operating performances while deciding on takeover premiums. In sum, we find that similar to the long-term stock return performance findings, results of long-term operating performance are dependent on methodological choices.

\subsection{Relationship among Long-term Operating Performance, Long-term Stock Return Performance, and Short-term Abnormal Return}

In this section, we investigate the relationship among long-term operating performance, long-term stock return performance, and short-term abnormal return. The motivation for this analysis is to test whether or not long-term abnormal return is related to the longterm operating performance of the acquiring firms, and whether or not short-term performance is an indicator of long-term stock return performance. We expected that if the market is behaving rationally, it will take note of the firm's operating performance, which in turn will be reflected in long-term stock return performance ${ }^{64}$. We further hypothesized that the market will react around the announcement date to an acquisition

\footnotetext{
${ }^{64}$ However, we recognize that stock return is a forward looking measure and operating performance is a historical measure.
} 
event and hence there will not be any systematic relationship between short-term and long-term stock return performance.

In order to test our conjectures, we regressed the acquiring firm's long-term abnormal return on long-term abnormal operating performance and short-term abnormal return. We present our results in Table 6.3 .

Table 6.3 Impact of Operating Performance and Short-run Performance on Longrun Abnormal Return

The dependent variable is the matching firm adjusted BHAR (BHAR6). This refers to the long-term abnormal stock return of the acquiring firm. Independent variables include CAR3 (cumulative abnormal return over 0 to +2 days) to proxy for short-term abnormal return and MDIFFAVG ("Matching firm adjusted post and pre difference"). MDIFFAVG is the average of the difference between "Matching adjusted post average cash flow to total asset" and "Matching adjusted pre average cash flow to total asset" and refers to the long-term abnormal operating performance. The number of cases included in the analysis is 628 .

\begin{tabular}{llllllll}
\hline & (Constant) & CAR3 & MDIFFAVG & R Square & $\begin{array}{l}\text { Adj. R } \\
\text { Square }\end{array}$ & F-stat & Sig. \\
\hline Beta & 0.115 & 0.556 & $1.723 * * *$ & 0.090 & 0.068 & 4.054 & 0.000 \\
t-stat & 0.751 & 0.741 & 5.595 & & & & \\
Sig. & 0.453 & 0.459 & 0.000 & & & & \\
\hline Note $(1): * * *$, and $* * *$ indicate statistical significance at $10 \%, 5 \%$, and 1\% levels respectively.
\end{tabular}

(2): We obtained similar results for the median values. In the above regression model, year dummy and industry dummy variables are included (not reported). Results are similar without these dummy variables.

As expected, we found that long-term abnormal operating performance (MDIFFAVG) is strongly related (positive with significance value of 0.000 ) to the long-term abnormal stock return and short-term performance does not show any significant relationship (see Table 6.3). The results imply that (i) acquiring firms' stock returns are coincidental to their operating results, and (ii) the market reacts to an announcement event around the event date and the reaction is not carried further to a long-term period, as expected in an efficient market. The results presented above are interesting, but not surprising. 


\section{CHAPTER 7: RESULTS: DIFFERENTIATING CHARACTERISTICS BETWEEN ACQUIRING AND NON-ACQUIRING FIRMS}

In this chapter we report the differentiating characteristics between acquiring firms and non-acquiring firms. For acquiring firms, only one event is considered in case of multiple acquisitions by a firm in any year. Results are presented in two sub-sections: for (i) firm specific variables, and (ii) governance variables. Within the firm specific variables, we considered firm size (total asset), R\&D focus ( $\& \& D$ intensity), leverage (debt to total asset), growth potential (price to book ratio), average sales growth, past performance (return on equity), and past cash reserve (cash flow to total asset). Within the governance variables, we considered CEO cash pay and total pay, pay ratio (ratio of option pay and outstanding option value to cash pay), percentage of inside directors, whether or not board chair is related, board size, CEO ownership, blockholder ownership (individuals other than directors and institutions owning more than $10 \%$ shares), and director ownership. We also investigated the role of CEO hubris in making an acquisition decision. CEO excess pay was used as a proxy for CEO hubris. CEO excess pay is the portion of CEO pay attributed to the firm's governance variables (see Appendix L for a detailed explanation). Two different forms of CEO excess pay were used in the analysis: (i) CEO cash excess pay, and (ii) CEO total excess pay.

Descriptive statistics of firm specific variables and governance variables are presented in

Table 7.1 and the results of univariate and multivariate analysis are presented in sections 7.1 and 7.2 . 


\section{Table 7.1 Descriptive Statistics of Firm Specific Variables and Governance Variables for Acquiring and Non-acquiring Firms}

The sample consisted of 1168 annual observations for acquiring (968 observations) and non-acquiring firms (200 observations) between 1993 and 2002 for the firm-specific variables and 838 (638 for acquiring firms and 200 for non-acquiring firms) for the governance variables between 1997 and 2002. For acquiring firms, only one event was considered in case of multiple acquisitions by a firm in any year. For nonacquiring firms, year 2001 data was considered in the analysis.

\section{Panel A. Firm specific variables}

"Total asset" is the sum of all fixed and current assets of the acquiring firm as appear in the balance sheet for the year prior to the year in which acquisition is made. "R\&D intensity" is the ratio of R\&D expenditure to sales revenue in the prior year. "Leverage" is the ratio of (current liability + long term debt) to total asset in the prior year. "Price to book value" is the ratio of the firm's market value to book value in the prior year. "Std. dev. of retum on asset" is the standard deviation of the firm's return on asset over five prior years. The "average sales growth" is the average of individual year's sales growth over five years prior to the year of acquisition. "Cash flow to total asset" is the ratio of the firm's cash flow to total asset in the prior year. "Return on equity" is the ratio of net income to net worth of the firm in the prior year.

\begin{tabular}{llll}
\hline & Mean & Median & Std. Dev \\
\hline Total Asset (TASST1) in '000\$ & 1148227.74 & 149073.50 & 2761491.7 \\
R\&D Intensity (RNDInty1) (ratio) & 0.05 & 0.00 & 0.21 \\
Leverage (Lever1) (ratio) & 0.47 & 0.48 & 0.22 \\
Price to book value (PrBV1) (ratio) & 2.47 & 1.90 & 2.12 \\
Std. dev. of ROA (StdROA) \% & 10.61 & 5.10 & 14.22 \\
Average sales growth (AvgSgrth) (average ratio) & 0.75 & 0.24 & 2.04 \\
Return on equity (Requty1) (\%) & 2.68 & 8.51 & 22.98 \\
Cash flow to total asset (CFTasst1) (ratio) & 0.07 & 0.08 & 0.13 \\
\hline
\end{tabular}

\section{Panel B. Governance variables}

"CEO cash pay" is the sum of salary and annual cash bonus. "CEO total pay" is the sum of salary, cash bonus, and realized stock option pay in that year. The compensation data were obtained from management information circulars. "Pay ratio" is the ratio of CEO's stock option value (CEO's aggregate realized option value in a year + CEO's unexercised option value) to cash pay.

"CEO is related" is a dummy variable equal to " 1 " if the chair is related to management or the board, " 0 " otherwise. For example, if the CEO is also chair of the board, the dummy variable is equal to " 1 ". "Percentage of inside directors" is the ratio of related directors to total board size. "Board size" is the number of directors on the board. "CEO ownership" is the percentage of outstanding shares owned by the CEO. Subsequently, three categories are created for CEO ownership, namely, for less than $5 \%, 5-25 \%$, and more than $25 \%$. "Blockholder ownership" is the percentage of outstanding shares owned by individuals or institutions other than the directors. If the blockholder ownership is less than $10 \%$, the input value for this variable is " 0 ". Subsequently, three categories are created for blockholder ownership, namely, for less than $10 \%, 10-25 \%$, and more than $25 \%$. "Director ownership" is the percentage of outstanding shares owned by all directors (including the CEO) of the firm. Subsequently, three categories are created for director ownership, namely, for less than $5 \%, 5-25 \%$, and more than $25 \%$. 


\begin{tabular}{llll}
\hline & Mean & Median & Std. Dev \\
\hline CEO cash pay (cashpay) in \$ & 536976.32 & 364827.50 & 514297.82 \\
CEO total pay (totalpay) in \$ & 765088.22 & 419375.00 & 956015.61 \\
Pay ratio (PayRat1) (ratio) & 3.64 & 0.69 & 7.11 \\
Percentage of inside director (Pindir) (ratio) & 0.33 & 0.31 & 0.17 \\
Chair is related (ChrRel) & 0.64 & 1.00 & 0.48 \\
Board Size (Bdsize) & 8.11 & 7.00 & 2.83 \\
CEO ownership (CEOown) \% & 10.46 & 1.79 & 18.38 \\
CEO ownership (<5\%) (CEOOwn1) \% & 64.00 & 100.00 & 48.00 \\
CEO ownership (5-25\%) (CEOOwn2) \% & 22.00 & 00.00 & 41.00 \\
CEO ownership (>25\%) (CEOOwn3) \% & 14.00 & 00.00 & 35.00 \\
Blockholder ownership (Blkown) \% & 10.08 & 0.00 & 19.81 \\
Blockholder ownership (<10\%) (BlkOwn1) \% & 71.00 & 100.00 & 45.00 \\
Blockholder ownership (10-25\%) (BlkOwn2) \% & 13.00 & 00.00 & 34.00 \\
Blockholder ownership (>25\%) (BlkOwn3) \% & 15.00 & 00.00 & 36.00 \\
Director ownership (Dirown) \% & 18.15 & 10.75 & 19.86 \\
Director ownership (<5\%) (DirOwn1) \% & 37.00 & 00.00 & 48.00 \\
Director ownership (5-25\%) (DirOwn2) \% & 34.00 & 00.00 & 47.00 \\
Director ownership (>25\%) (DirOwn3) \% & 30.00 & 00.00 & 46.00 \\
\hline
\end{tabular}

\subsection{Firm Specific Variables}

In chapter 3, we hypothesized that a firm with larger size, higher R\&D intensity, lower leverage, higher growth potential, better sales growth, higher cash reserves, and superior past performance will more likely be an acquirer in the subsequent time period. From univariate (see Table 7.2, Panel A) and multivariate (see Table 7.2, Panel B) analyses, we found that firm size (total asset), leverage, growth potential (price to book value), and past sales performance (average sales growth) did not play any significant role in acquisition decisions. None of the coefficients for these variables were statistically significant (at $10 \%$ significance level).

Consistent with our hypothesis and conjectures, from the univariate analysis (see Table 7.2, Panel A), we found that acquiring firms have significantly higher cash reserves (significance level is 0.00 ) and better past performances (return on equity) (significance 
level is 0.00 ) compared to the non-acquiring firms. Contrary to our expectation, we found that $R \& D$ intensity was higher for non-acquiring firms. However, we need to interpret this result with caution. R\&D expenditure is highly dependent on industry affiliation and in the Canadian context, acquisition by high-tech firms has also been time dependent. High-tech firms with more R\&D expenditures made more acquisition towards the end of 1990s (Crosbie annual report 2001 and 2002). After the stock market depression in 20002001, we saw a sharp decrease in M\&A activities by high-tech firms (Crosbie annual report 2001 and 2002). Therefore, it is imperative to control for time dimension and industry segment in analyzing the $R \& D$ intensity impact on the acquisition decision with multivariate analysis; the corresponding result is reported in Table 7.2, Panel B.

Table 7.2, Panel B presents the results of two logistic regression models. Both cash flow to total asset and return on equity are indicators of past performance; the impact of these variables is investigated separately in Model 1 and Model 2 to avoid a multicollinearity problem. We controlled for industry effect and year effect by using dummy variables in the regression models. Hosmer-Lemeshow tests showed that both models represent a good fit. Through this multivariate analysis, we found that acquiring firms have higher R\&D intensity (significance level is 0.04 in Model 1 and 2), higher cash flow to total asset (significance level is 0.08 in Model 1), and higher return on equity (significance level is 0.00 in Model 2). As argued earlier, we found a significant change in the R\&D intensity variable coefficient once we controlled for industry effect and year effect. In sum, the results presented in Table 7.2 supports the argument that firms with higher cash 
reserves, better past performances, and higher R\&D focus (high-tech firms) are more

likely to be acquirers.

Table 7.2 Differentiating Characteristics Corresponding to Firm Specific Variables

The sample consisted of 838 annual observations for acquiring and non-acquiring firms between 1997 and 2002. For acquiring firms, only one event was considered in case of multiple acquisitions by the firm in any year. In the regression models, number of cases is less than 838 due to list-wise deletion of the cases with missing data.

"Total asset" is the sum of all fixed and current assets of the acquiring firm as they appeared in the balance sheet for the year prior to the year in which acquisition is made. "R\&D intensity" is the ratio of R\&D expenditure to sales revenue in the prior year. "Leverage" is the ratio of (current liability + long term debt) to total asset in the prior year. "Price to book value" is the ratio of the firm's market value to book value in the prior year. "Std. dev. of return on asset" is the standard deviation of the firm's return on assets over five prior years. "Average sales growth" is the average of individual year's sales growth over five years prior to the year of acquisition. "Cash flow to total asset" is the ratio of the firm's cash flow to total assets in the prior year. "Return on equity" is the ratio of net income to net worth of the firm in the prior year.

Panel A. Univariate analysis

The mean differences of the firm specific variables are calculated for the acquiring and non-acquiring firms and t-statistics and significance level are reported.

\begin{tabular}{lllll}
\hline & & $\begin{array}{l}\text { Mean } \\
\text { Difference }\end{array}$ & t-stat & Sig. \\
\hline Total Asset (TASST1) & Equal variances assumed & 199830.40 & 0.92 & 0.360 \\
(in '000\$) & Equal variances not assumed & 199830.40 & 0.90 & 0.369 \\
R\&D Intensity (RNDInty1) & Equal variances assumed & $-0.05^{* * *}$ & -2.92 & 0.004 \\
(ratio) & Equal variances not assumed & $-0.05^{* *}$ & -2.16 & 0.032 \\
Leverage (Lever1) & Equal variances assumed & -0.01 & -0.79 & 0.428 \\
(ratio) & Equal variances not assumed & -0.01 & -0.68 & 0.496 \\
Price to book value (PrBV1) & Equal variances assumed & -0.24 & -1.33 & 0.183 \\
(ratio) & Equal variances not assumed & -0.24 & -1.08 & 0.282 \\
Std. dev. of ROA (StdROA) (\%) & Equal variances assumed & $-7.30^{* * *}$ & -6.62 & 0.000 \\
& Equal variances not assumed & $-7.30^{* * *}$ & -4.98 & 0.000 \\
Average sales growth (AvgSgrth) & Equal variances assumed & -0.15 & -0.93 & 0.355 \\
(average ratio) & Equal variances not assumed & -0.15 & -0.78 & 0.438 \\
Cash flow to total asset & Equal variances assumed & $0.06^{* * *}$ & 5.83 & 0.000 \\
(CFTASST1) (ratio) & Equal variances not assumed & $0.06^{* * *}$ & 4.52 & 0.000 \\
Return on equity (REQUTY1) (\%) & Equal variances assumed & $11.66^{* * *}$ & 6.12 & 0.000 \\
& Equal variances not assumed & $11.66^{* * *}$ & 4.87 & 0.000 \\
\hline
\end{tabular}

Note: ${ }^{*}, * *$ and ${ }^{* * *}$ indicate statistical significance at $10 \%, 5 \%$, and $1 \%$ levels respectively.

Panel B. Logit regression on firm specific variables

Logit regression of "acquire" dichotomous variable on firm specific variables, industry and year control. If a firm has made an acquisition in a year between 1993 and 2002, "acquire" $=1$, otherwise "acquire" $=0$.

Beta coefficient value, Wald-statistics and significance level obtained through Logit regression are reported. Dummy variables were included to control for the "year" effect and "industry" effect. Results for these dummy variables are not reported in the table. In order to avoid extreme value (outlier) problem, top $1 \%$ and bottom $1 \%$ data of each variable in the regression model were deleted. 


\begin{tabular}{|c|c|c|c|}
\hline & & Model 1 & Model 2 \\
\hline \multirow{3}{*}{ Total Asset (TASST1) } & Beta & 0.00 & 0.00 \\
\hline & Wald & 1.29 & 0.27 \\
\hline & Sig. & 0.26 & 0.61 \\
\hline \multirow[t]{3}{*}{ R\&D Intensity (RNDINTY1) } & Beta & $1.61^{* *}$ & $1.58^{* *}$ \\
\hline & Wald & 4.32 & 4.44 \\
\hline & Sig. & 0.04 & 0.04 \\
\hline \multirow[t]{3}{*}{ Leverage (LEVER1) } & Beta & 0.29 & 0.40 \\
\hline & Wald & 0.13 & 0.23 \\
\hline & Sig. & 0.72 & 0.63 \\
\hline \multirow[t]{3}{*}{ Price to Book Value (PRBV1) } & Beta & -0.04 & 0.02 \\
\hline & Wald & 0.29 & 0.07 \\
\hline & Sig. & 0.59 & 0.80 \\
\hline \multirow{3}{*}{$\begin{array}{l}\text { Std. Dev. Of Return on Asset } \\
\text { (STDROA) }\end{array}$} & Beta & -0.02 & -0.02 \\
\hline & Wald & 2.00 & 2.58 \\
\hline & Sig. & 0.16 & 0.11 \\
\hline \multirow[t]{3}{*}{ Average Sales Growth (AVGSGRTH) } & Beta & -0.01 & 0.04 \\
\hline & Wald & 0.01 & 0.13 \\
\hline & Sig. & 0.91 & 0.72 \\
\hline \multirow[t]{3}{*}{ Cash Flow to Total Asset (CFTASST1) } & Beta & $2.53 *$ & \\
\hline & Wald & 3.10 & \\
\hline & Sig. & 0.08 & \\
\hline \multirow[t]{3}{*}{ Return on Equity (REQUTY1) } & Beta & & $0.02 * * *$ \\
\hline & Wald & & 8.89 \\
\hline & Sig. & & 0.00 \\
\hline \multirow[t]{3}{*}{ Constant } & Beta & 11.24 & 11.26 \\
\hline & Wald & 0.06 & 0.05 \\
\hline & Sig. & 0.81 & 0.82 \\
\hline \multicolumn{2}{|l|}{$\mathrm{N}$} & 951 & 938 \\
\hline \multicolumn{2}{|l|}{-2 Log likelihood } & 266.73 & 255.22 \\
\hline \multicolumn{2}{|l|}{ Cox \& Snell R Square } & 0.44 & 0.44 \\
\hline \multicolumn{2}{|l|}{ Nagelkerke R Square } & 0.77 & 0.77 \\
\hline \multicolumn{4}{|l|}{ Hosmer and Lemeshow Test } \\
\hline Chi-square & & 2.90 & 1.12 \\
\hline df & & 8.00 & 8.00 \\
\hline Sig. & & 0.94 & 1.00 \\
\hline
\end{tabular}




\subsection{Governance Variables}

In the previous chapter, we hypothesized that a firm with a larger board size, a higher percentage of inside directors, a related board chairperson, a higher option pay to cash pay ratio, lower CEO ownership, and lower blockholder ownership would more likely be an acquirer in the subsequent time period. We also hypothesized that acquiring firms' CEOs would show a higher level of CEO hubris. CEO excess pay was used as a proxy for CEO hubris. Since we used economic variables and governance variables in determining CEO excess pay, results of CEO hubris analysis is presented separately in Table 7.4 (please refer to Appendix L for a detailed discussion on CEO hubris and proxy variable calculation).

From the univariate (Table 7.3, Panel A) analysis, we found that acquiring firms have higher pay ratios ((option pay + option value) / cash pay), lower inside director ratios, higher board sizes, and lower blockholder ownerships. Coefficients of these variables were significant at the $10 \%$ level. The results, except for the inside director ratio, were consistent with our hypothesis. We did not find any significant difference for CEO ownership between acquiring and non-acquiring firms. While we performed multivariate analysis using logistic regression (Table 7.3, Panel B) to control for year effect and industry effect, it appears that only blockholder ownership played a significant role in making an acquisition decision (Significance level of 0.03 in Model 1 and Model 2). Two models are presented with and without considering board size effect. 
From bi-variate correlation analysis it appeared that board size highly correlated with firm size. Therefore, we decided to investigate the results more carefully with and without board size effect in the regression models. We also investigated the impact of pay ratio, CEO ownership, and director ownership separately using logistic regression, but the coefficients of none of these variables were statistically significant (results are not reported in the table).

Interestingly, both univariate and multivariate (logistic regression) analyses revealed that CEO total pay was significantly higher for acquiring firms. Similar results were obtained for CEO cash pay. However, we did not find any theory in the literature to support these findings.

The results for CEO hubris impact on acquisition decision are presented in Table 7.4. Both univariate analysis and logistic regression analysis confirms that CEO hubris levels are significantly higher for acquiring firms compared to the CEOs of non-acquiring firms. In other words, CEOs in acquiring firms enjoyed more power in making acquisition decisions. These findings are consistent with the viewpoint of Roll (1986), Berkovitch and Narayanan (1993), and Hayward and Hambrick (1997). However, unlike other studies, we used a direct and integrated approach in investigating the impact of CEO hubris on a firm's acquisition decision ${ }^{65}$.

\footnotetext{
${ }^{65}$ Earlier studies have either tested the impact of CEO hubris on takeover premium (Roll 1986), or used a number of separate variables to proxy for CEO hubris without considering the confounding effect (Hayward \& Hambrick, 1997).
} 


\section{Table 7.3 Differentiating Characteristics for Governance Variables}

The sample consisted of 838 annual observations for acquiring and non-acquiring firms between 1997 and 2002. For acquiring firms, only one event was considered in the case of multiple acquisitions by the firm in any year. In the regression models, the number of cases is less than 838 due to list-wise deletion of the cases with missing data.

"CEO cash pay" is the sum of salary and annual cash bonus. "CEO total pay" is the sum of salary, cash bonus, and realized stock option pay in that year. The compensation data were obtained from management information circulars. "Pay ratio" is the ratio of CEOs' stock option values (CEO's aggregate realized option value in a year + CEO's unexercised option value) to cash pay.

"CEO is related" is a dummy variable equal to " 1 " if the chair is related to management or the board, " 0 " otherwise. For example, if the CEO is also chair of the board, the dummy variable is equal to "1". "Percentage of inside directors" is the ratio of related directors to total board size. "Board size" is the number of directors on the board. "CEO ownership" is the percentage of outstanding shares owned by the CEO. Subsequently, three categories are created for CEO ownership, namely, for less than 5\%, 5-25\%, and more than $25 \%$. "Blockholder ownership" is the percentage of outstanding shares owned by individuals or institutions other than the directors. If the blockholder ownership is less than $10 \%$, the input value for this variable is " 0 ". Subsequently three categories are created for blockholder ownership, namely, for less than $10 \%, 10-25 \%$, and more than $25 \%$. "Director ownership" is the percentage of outstanding shares owned by all directors (including the $\mathrm{CEO}$ ) of the firm. Subsequently, three categories are created for director ownership namely, for less than 5\%,5-25\%, and more than $25 \%$. 
Panel A. Univariate analysis

Mean difference of the governance variables were calculated for the acquiring and non-acquiring firms and the t-statistics and significance level are reported.

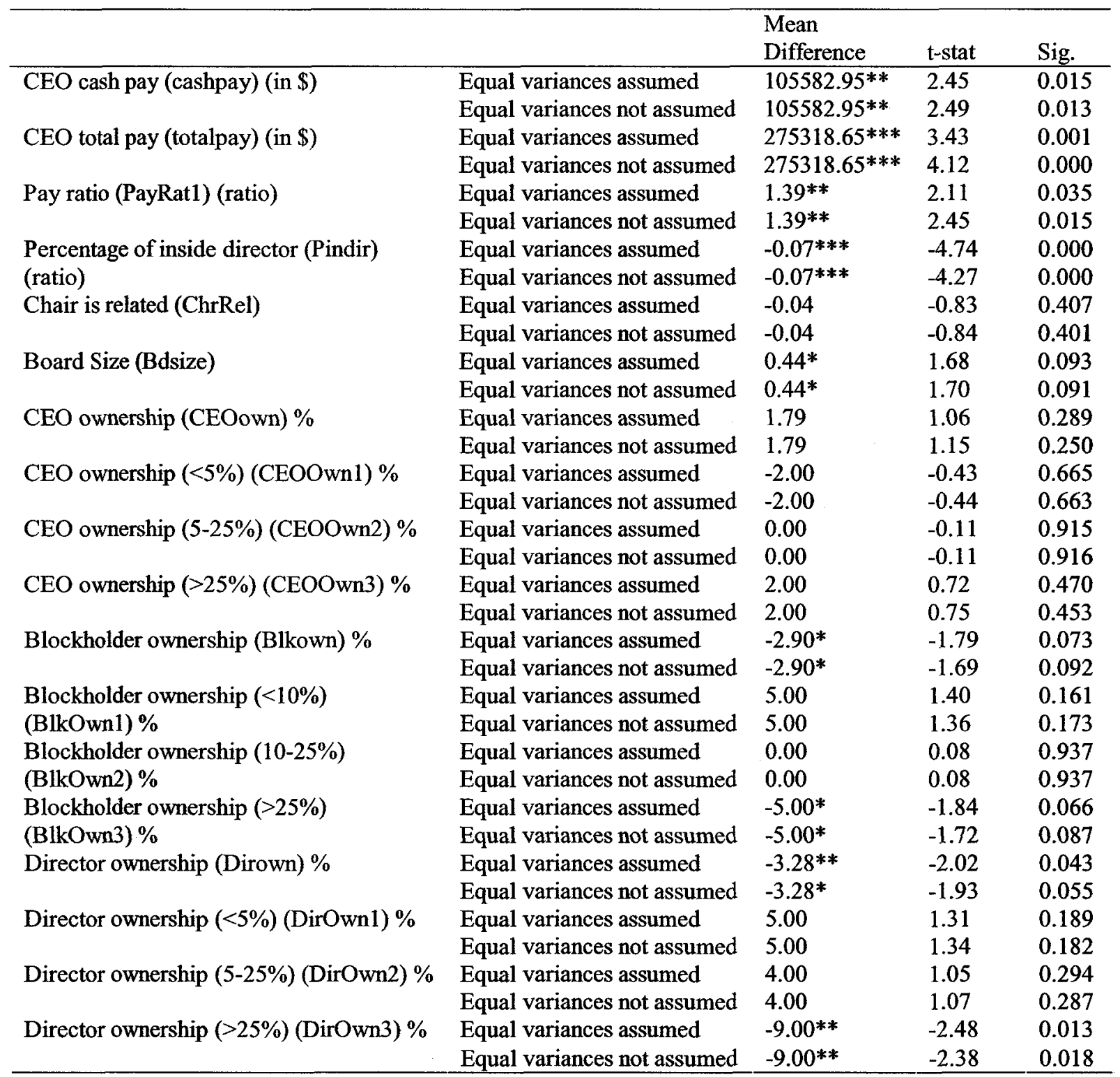

Note: ${ }^{*},{ }^{* *}$, and ${ }^{* * *}$ indicate statistical significance at $10 \%, 5 \%$, and $1 \%$ levels respectively. 
Panel B. Logit regression on governance variables

Logit regression of "acquire" dichotomous variable on governance variables, industry and year control. If a firm made an acquisition in a year between 1997 and 2002, "acquire" $=1$, otherwise "acquire" $=0$.

Beta coefficient value, Wald-statistics and significance levels obtained through Logit regression are reported. Dummy variables are included to control for the "year" effect and "industry" effect. Results for these dummy variables are not reported in the table. In order to avoid extreme value (outlier) problem, top $1 \%$ and bottom $1 \%$ data of each variable in the regression model were deleted.

\begin{tabular}{|c|c|c|c|}
\hline & & Model 1 & Model 2 \\
\hline \multirow[t]{3}{*}{ Total Asset (TASST1) } & Beta & 0.00 & 0.00 \\
\hline & Wald & 0.18 & 0.75 \\
\hline & Sig. & 0.67 & 0.39 \\
\hline \multirow{3}{*}{ Total CEO Pay (TOTALPAY) } & Beta & $0.00^{* *}$ & $0.00 * *$ \\
\hline & Wald & 3.97 & 3.99 \\
\hline & Sig. & 0.05 & 0.05 \\
\hline \multirow[t]{3}{*}{ Percentage of Inside Director (PINDIR) } & Beta & -1.03 & -0.84 \\
\hline & Wald & 0.92 & 0.65 \\
\hline & Sig. & 0.34 & 0.42 \\
\hline \multirow[t]{3}{*}{ Chair is Related (CHRREL) } & Beta & -0.25 & -0.26 \\
\hline & Wald & 0.50 & 0.53 \\
\hline & Sig. & 0.48 & 0.47 \\
\hline \multirow[t]{3}{*}{ Blockholder Ownership - 5 to $25 \%$ (BLKOWN2) } & Beta & -0.63 & -0.64 \\
\hline & Wald & 1.47 & 1.48 \\
\hline & Sig. & 0.23 & 0.22 \\
\hline \multirow[t]{3}{*}{ Blockholder Ownership > 25\% (BLKOWN3) } & Beta & $-1.07 * *$ & $-1.10^{* *}$ \\
\hline & Wald & 4.59 & 4.92 \\
\hline & Sig. & 0.03 & 0.03 \\
\hline \multirow[t]{3}{*}{ Board Size (BDSIZE) } & Beta & -0.06 & \\
\hline & Wald & 0.59 & \\
\hline & Sig. & 0.44 & \\
\hline \multirow[t]{3}{*}{ Constant } & Beta & -0.78 & $-1.27 * * *$ \\
\hline & Wald & 0.92 & 6.12 \\
\hline & Sig. & 0.34 & 0.01 \\
\hline \multicolumn{2}{|l|}{$\mathrm{N}$} & 652 & 653 \\
\hline \multicolumn{2}{|l|}{-2 Log likelihood } & 237.14 & 237.73 \\
\hline \multicolumn{2}{|l|}{ Cox \& Snell R Square } & 0.49 & 0.49 \\
\hline \multicolumn{2}{|l|}{ Nagelkerke R Square } & 0.76 & 0.76 \\
\hline \multicolumn{4}{|l|}{ Hosmer and Lemeshow Test } \\
\hline \multicolumn{2}{|l|}{ Chi-square } & 1.84 & 2.17 \\
\hline & 8.00 & 8.00 \\
\hline \multicolumn{2}{|l|}{ Sig. } & 0.99 & 0.98 \\
\hline
\end{tabular}




\section{Table 7.4 Analysis of the Impact of CEO Hubris on M\&A Decision}

Panel A. Univariate analysis

"CEO hubris" is the CEO excess pay, which is the portion of CEO pay attributed to the firm's governance variables (see Appendix L for detail explanation). Two different forms of CEO excess pay were used in the regression: (i) CEO cash excess pay, and (ii) CEO total excess pay.

Means of CEO cash excess pay and CEO total excess pay were calculated and compared for the two groups of acquiring firms and non-acquiring firms over 1997-2002 period.

\begin{tabular}{|c|c|c|c|c|c|c|}
\hline & & $\begin{array}{l}\text { Acquiring } \\
\text { Firm }\end{array}$ & $\begin{array}{l}\text { Non Acquiring } \\
\text { Firm }\end{array}$ & $\begin{array}{l}\text { Mean } \\
\text { Difference }\end{array}$ & t-stat & Sig. \\
\hline \multirow{4}{*}{$\begin{array}{l}\text { CEO cash } \\
\text { excess pay } \\
\text { (CEXPAY } 1 T)\end{array}$} & & $\mathrm{N}=526$ & $\mathrm{~N}=143$ & & & \\
\hline & Equal variances & 431191 & 302075 & $38216 * *$ & 2448 & 0015 \\
\hline & Equal variances & & & & & \\
\hline & not assumed & 431.191 & 392.975 & $38.216^{* *}$ & 2.359 & 0.019 \\
\hline \multirow{3}{*}{$\begin{array}{l}\text { CEO total } \\
\text { excess pay } \\
\text { (TEXPAY1T) }\end{array}$} & & $\mathrm{N}=528$ & $N=141$ & & & \\
\hline & Equal variances & 316305 & 260174 & $56131 * * *$ & 2789 & 0.005 \\
\hline & $\begin{array}{l}\text { Equal variances } \\
\text { not assumed }\end{array}$ & 316.305 & 260.174 & $56.131 * * *$ & 2.615 & 0.010 \\
\hline
\end{tabular}

Panel B. Logit regression on CEO hubris

Logit regression of "acquire" dichotomous variable on CEO hubris is presented. If a firm made an acquisition in a year between 1993 and 2002, "acquire" = 1, otherwise "acquire" = 0. "CEO hubris" is the CEO excess pay, which is the portion of CEO pay attributed to the firm's governance variables (See Appendix $\mathrm{L}$ for a detailed explanation). Two different forms of CEO excess pay are used in the regression: (i) CEO cash excess pay, and (ii) CEO total excess pay. We did not include any other firm-specific or governance variables in the model as those variables were used to obtain the estimate of CEO excess pay.

\begin{tabular}{|c|c|c|c|}
\hline & & Model 1 & Model 2 \\
\hline \multirow[t]{3}{*}{ CEO cash excess pay (CEXPAY1T) } & Beta & $0.001 * *$ & \\
\hline & Wald & 5.89 & \\
\hline & Sig. & 0.02 & \\
\hline \multirow[t]{3}{*}{ CEO total excess pay (TEXPAY1T) } & Beta & & $0.001 * * *$ \\
\hline & Wald & & 7.62 \\
\hline & Sig. & & 0.01 \\
\hline \multirow[t]{3}{*}{ Constant } & Beta & $0.70 * * *$ & $0.96 * * *$ \\
\hline & Wald & 7.37 & 38.15 \\
\hline & Sig. & 0.01 & 0.00 \\
\hline $\mathbf{N}$ & & 669 & 669 \\
\hline-2 Log likelihood & & 688.12 & 681.28 \\
\hline Cox \& Snell R Square & & 0.01 & 0.01 \\
\hline Nagelkerke R Square & & 0.01 & 0.02 \\
\hline \multicolumn{4}{|l|}{ Hosmer and Lemeshow Test } \\
\hline Chi-square & & 15.87 & 9.68 \\
\hline df & & 8 & 8 \\
\hline Sig. & & 0.04 & 0.29 \\
\hline
\end{tabular}


In summary, with respect to firm-specific variables, we found that firms with higher cash reserves, better past performances, and a higher $\mathrm{R} \& \mathrm{D}$ focus (high-tech firms) are more likely to be acquirers. Higher levels of cash reserves and better past performances give more economic strength to a firm to make an acquisition. Moreover, high-tech firms with more R\&D focus tend to acquire other companies in order to stay innovative and to eliminate the threat from a future potential competitor by internalizing it.

With respect to the governance variables, we found that acquiring firms have higher pay ratios (option pay plus option value dividend by cash pay), lower inside director ratios, higher board sizes, and lower blockholder ownerships. However, these results are not supported in multivariate analysis. Higher levels of option pay allow the management to take the extra risks involved in the corporate acquisition activity. Option pay gives an opportunity to the management to benefit from an increased stock price while protecting them from the downside risk. It appears that inside directors are more conservative with respect to an acquisition decision. Perhaps they are unsure about the changes within the organization following a successful acquisition deal. It is not uncommon to see a major change in the management team after a significant acquisition by a firm (Martin \& McConnell, 1991).

Significant levels of blockholder ownership in a firm's ownership structure acts as a governance control mechanism whereby the blockholders with significant ownership watch management's actions more closely. An absence of any significant level of 
blockholder ownership gives more power and opportunity to the management team to make an acquisition decision. As expected, we also found support for the conjecture that CEO hubris levels were significantly higher for the acquiring firms. Interestingly, results also indicate that CEO total pay and cash pay were significantly higher for acquiring firms. However, we did not find any theory in the literature to support this finding.

Further, the results from differentiating characteristics analyses have highlighted at least two motives behind an acquisition decision. First, we found strong support for an "empire building" motive behind M\&A. Our results indicate that firms with higher levels of cash reserves and CEO hubris are more likely to be acquirers. In other words, firms with more CEO discretion and excess resources tend to grow in size through acquisition. Second, we found support for a strategic motive for high-tech firms behind M\&A. High-tech firms were more likely to make an acquisition in order to stay innovative and preempt competition. 


\section{CHAPTER 8: SUMMARY AND CONCLUSIONS}

In this chapter, we summarize the major findings of the study. Specific contributions and benefits of the study are discussed in the following chapter.

The main objectives of this research were to investigate (i) the short-term and the longterm performance of an acquiring firm following an acquisition event, and (ii) the differentiating characteristics of acquiring firms in comparison with non-acquiring firms. It was also the intent of the research to investigate the robustness of results by using different methodologies in testing the hypotheses, especially for long-term performance analysis, as a considerable level of debate surrounding the methodologies used in detecting long-term abnormal returns exists in the literature.

With respect to short-term abnormal return, we found that overall, there were positive and significant abnormal returns for the acquiring firm shares around the announcement date. The results were robust across single acquirers and multiple acquirers ${ }^{66}$. Overall, short-term abnormal return results were similar to those reported in earlier Canadian studies (Eckbo and Thorburn, 2000: Yuce \& Ng, 2005). We also found that the market reacted more favourably to (i) unrelated acquisitions, (ii) relatively larger deals, (iii) deals involving target firms from outside Canada and the U.S., (iv) deals involving private targets, (v) deals with higher target premiums, and (vi) deals by acquiring firms with higher levels of managerial ownership. We also found limited support for the hypotheses that the market reacts unfavorably for the deals that were purely stock-financed and were

\footnotetext{
${ }^{66}$ Multiple acquirers make more than one acquisition in a calendar year.
} 
announced by growth acquiring firms. Interestingly, our results show that within 15 days of the acquisition announcement, cumulative abnormal returns turn insignificant. This implies that initially the market overreacts to an acquisition event, which is then corrected in subsequent days. This is consistent with our findings with regards to long-term stock return (discussed below), as we did not find any significant long-term abnormal returns for acquiring firms.

With respect to long-term stock return performance, the results are quite interesting and make a significant contribution towards the debate surrounding long-term performance methodologies. Once we combined the findings of the event-time approach and the calendar-time approach, we did not find any strong support for long-term abnormal returns for acquiring firms which was robust across all methodologies (BHAR univariate and multivariate, and F-F three-factor regression results). Our findings suggest that BHAR results vary significantly with respect to benchmark choices ${ }^{67}$ and F-F regression models fail to explain the stock returns satisfactorily in many instances. This interesting and significant finding leads us to the conclusion that the earlier studies reporting long-term underperformance should be viewed with caution for the following reasons: (i) investigations are generally carried out using one of the two approaches (event-time or calendar-time) and the various adjustments discussed previously are not considered, (ii) in the case of the investigation of several deal-specific, firm-specific, and governance factors, only univariate results are presented, which ignores the confounding effect, and finally, (iii) there are still controversies surrounding the long-term

\footnotetext{
${ }^{67}$ As reported in Table 5.1 and Table 5.4, we find that test results varied significantly with benchmark choices and adjustments for cross-sectional dependence.
} 
performance methodologies that may distort empirical results. We also did not find any improvement in long-term operating performance in general once we adopted the matching firm approach. Again, our results show that long-term operating performance results vary according to methodological choices. Interestingly however, we found that there was a significant level of improvement in the long-term operating performance for relatively larger acquisition deals and that this finding was robust across methodological choices. This was consistent with the viewpoint that (i) only relatively larger deals are economically significant enough to impact the long-term operating performance of an acquiring firm, and (ii) acquiring firms pay significantly more attention and make better decisions for relatively larger deals. As reported earlier in chapter 4, takeover premiums were significantly higher for relatively larger deals, indicating that the market accounts for long-term operating performance when deciding on takeover premiums.

Finally, we investigated the differentiating characteristics between acquiring and nonacquiring firms. Our results show that with respect to "firm specific variables", firms with higher cash reserves, better past performances, and higher R\&D focus (high-tech firms) are more likely to be acquirers. Higher levels of cash reserves and better past performances give more economic strength to a firm to make acquisitions. Moreover, high-tech firms with more R\&D focus tend to acquire other companies possibly in order to stay innovative and to eliminate the threat from a future potential competitor by internalizing it. 
With respect to the governance variables, we found that acquiring firms have higher pay ratios (option pay plus option value dividend by cash pay), lower inside director ratios, higher board sizes and lower blockholder ownerships. Higher levels of option pay allow the management to take extra risks involved in the corporate acquisition activity. Option pay gives an opportunity to the management to benefit from an increased stock price while protecting them from the downside risk. It appears that inside directors are more conservative with respect to an acquisition decision. It is possible that they are unsure of the changes within the organization following a successful acquisition deal. It is not uncommon to see a major change in the management team after a significant acquisition by a firm.

A significant level of blockholder ownership in a firm's ownership structure acts as a governance control mechanism, whereby the blockholders with significant ownership watch the management's actions more closely. Absence of any significant level of blockholder ownership gives more freedom and opportunity to the management team to make an acquisition decision. We also found support for the conjecture that the CEO hubris levels are significantly higher for the acquiring firms. Interestingly, our results further demonstrate that CEO total pay and cash pay are significantly higher for acquiring firms. However, we did not find any theory in the literature to support this finding.

Further, the results from a differentiating characteristics analysis have shed light on M\&A motives and have highlighted at least two reasons behind an acquisition decision. First, we found strong support for an "empire building" motive behind M\&A. Our results 
indicate that firms with higher levels of cash reserves and CEO hubris are more likely to be acquirers. In other words, firms with more CEO discretion and excess resources tend to grow in size through acquisition. Second, we found support for strategic motives for high-tech firms behind M\&A. High-tech firms are more likely to make an acquisition in order to stay innovative and preempt competition. 
CHAPTER 9: CONTRIBUTIONS, LIMITATIONS, AND SUGGESTIONS FOR FURTHER RESEARCH

\subsection{Major Contributions of the Study}

This is the most comprehensive study on Canadian M\&A activity. It considers a significantly longer and more recent (1993-2002) period than previous studies. Although there have been some studies investigating short-term abnormal returns of acquiring firms with Canadian data, this study makes additional significant contributions. First, except for Yuce and Ng's (2005) study, all other Canadian studies report results based on pre-1990 data. Given the M\&A boom in Canada in the 1990 s, it is important to revisit some of the earlier results. Second, this is the first comprehensive study to investigate the implications of governance factors on short-term performance for acquiring firms. Third, this study presents results from both univariate and multivariate analyses in order to check the robustness of the results. Fourth, this study presents plausible explanations as to why the Canadian market reacts differently to an acquisition announcement compared to the U.S. market.

With respect to the long-term performance study, the contributions are more significant. This is the first comprehensive study with Canadian data to investigate long-term abnormal returns ${ }^{68}$ and operating performance with the same set of events. This is also the first comprehensive study to investigate the implications of governance factors on

\footnotetext{
${ }^{68}$ Andre et al. (2004) have investigated the long-term abnormal return with limited cases (143 nonoverlapping cases) and reported long-term underperformance. Only calendar-time approach had been adopted in the study and the sample size was quite limited.
} 
long-term performance for acquiring firms. Further, the impact of relative deal size is examined quite extensively across short-term return, long-term return, and long-term operating performance analyses. Most of the earlier studies have either ignored this issue or have used absolute deal size to consider the M\&A transaction size effect.

We believe that this study is the first one to identify the characteristics that separate an acquiring firm from a non-acquiring firm. In the process, the study tests the CEO hubris hypothesis as one of the motives behind an acquisition. However, unlike other studies, we have used a direct and integrated approach in investigating the impact of CEO hubris on a firm's acquisition decision. We have used CEO excess pay as a proxy for CEO hubris, considering an integrated perspective of governance weakness in a firm that leads to CEO hubris. None of the earlier studies have used any integrated measure to investigate the effect of CEO hubris on a firm's M\&A decision-making process.

In addition, this study pays considerable attention to the importance of methodologies on the robustness of results. Accordingly, various recent improvements in methodologies are incorporated in order to make the results more reliable. For example, in the case of the BHAR methodology, adjustments were made for skewness and cross-sectional dependence among various events. Also, six different benchmarks were used to show the results varied depending on benchmark choices. We also used propensity scores based on size and book-to-market value factors (Loughran \& Vijh, 1997) to identify a matching firm in order to eliminate a number of biases in detecting long-term abnormal performance. Long-term abnormal stock return performance was evaluated by using both 
the event-time and calendar time approaches. Long-term operating performance was investigated by using both industry-adjusted and matching firm-adjusted methodologies. For both long-term stock return performance and operating performance, we found that methodological choice plays a significant role in detecting long-term abnormal performance.

Finally, as the study investigated short-term abnormal returns, long-term abnormal stockreturn performance, and long-term abnormal operating performance with the same sample, it gave a unique opportunity to test the relationship among these performances and to check the "market inefficiency claim" by some of earlier studies with respect to long-term underperformance. For example, our results show that there are significant and positive cumulative abnormal returns around the announcement date. However, the market corrects its overreaction within 15 days and there is no long-term abnormal stock return in the next three-year period. Further, we found a consistent and integrated view of relative size, market reaction, and long-term operating performance of acquiring firms. We found that the market reacts more positively to the higher relative size deals, recognizing their economic significance; this is reflected in higher and significantly positive long-term operating performances for the same category of acquiring firms.

\subsection{Implications for Market Participants and Researchers}

First, this study presents plausible explanations for two puzzling phenomenon in M\&A literature, which are of significant interest to the researchers and practitioners. One is the 
positive abnormal returns experienced by Canadian acquirers and the other is the longterm underperformance of acquiring firms reported in a number of U.S., Canadian, and international studies. Explanations for the former puzzling observation lies within the deal-specific characteristics of Canadian M\&A and the regulatory environment of Canada. It appears that (i) the majority of the Canadian acquisitions are made through cash, whereas in U.S., the majority of deals are done through stock payment. Due to information asymmetry and valuation uncertainty surrounding a stock acquisition, the market may react more favourably to the cash financed deals; (ii) the size of U.S. acquiring firms is significantly larger as compared to Canadian acquirers. As a result, the relative size ${ }^{69}$ of an acquisition is higher in a Canadian context. Relatively larger deals carry more economic significance and lead to more pronounced reactions in the market; (iii) unlike the U.S. market, the Canadian market reacts positively to the unrelated acquisition announcements by recognizing the diversification benefits, and a significant number of Canadian deals are unrelated ${ }^{70}$. The answer to the second puzzle lies within the methodological choices employed to investigate long-term performance. Our results show that methodological choice drives the long-term abnormal return results reported in earlier studies and such observations are "myths and not realities".

Second, the market believes that relatively larger deals can bring more significant economic benefits to the acquiring firms and thus reacts more favorably to those deals.

\footnotetext{
${ }^{69}$ Ratio of target size and acquirer size.

${ }^{70}$ Further, Brealey et al., (2006) reported that more U.S. firms frequently adopt anti-takeover strategies such as shareholder's rights plan, poison pill, and shark repellent compared to Canadian firms, and in Canada, anti-takeover plans are typically rendered ineffective by the securities commission(s) at the request of the bidder. Due to the adoption of effective takeover deterrents by the target firms, acquirers' returns are lower in the U.S.
} 
Such optimism in the market is further supported by our results, which showed significantly better long-term operating performance for relatively larger deals. Therefore, it appears that acquiring firms' resources are better utilized if relatively larger targets are acquired ${ }^{71}$.

Third, results from this study show a relationship between the agency problem and M\&A deals. Our results show that the market reacts more favourably to the deals where acquiring firms have a higher level of managerial ownership. This implies that there is a "convergence of interest" between managers with significant levels of ownership and the firm's value maximization objective, and that such a phenomenon helps to mitigate agency problems. Further, our results show that CEOs with higher levels of hubris tend to make more acquisitions. Such acts would deprive common shareholders, as excess resources are used to make more acquisitions instead of being distributed to the shareholders.

Finally, results from this study imply that in order to gain a holistic perspective on M\&A activities, we need to rely and focus on an integrated analysis. Since this study uses the same dataset for investigating short-term and long-term performance issues, it helps to integrate our viewpoints and find explanations for some apparently puzzling observations. For example, contrary to conventional wisdom, our results show that takeover premiums have significantly positive impacts on short-term abnormal returns. However, further analysis reveals that takeover premiums are higher for relatively larger

\footnotetext{
${ }^{71}$ However, we acknowledge that there could be other strategic reasons (such as pre-empting competition) for acquiring a smaller target.
} 
deals and such deals show significantly better long-term operating performance. Hence, it appears logical that the market reacts positively to the deals with higher takeover premiums.

\subsection{Limitations}

First, the study does not consider financial firms. Inclusion of financial firms in the analysis might have an impact on the results. The study also considers only the completed deals, which gives only a partial picture of the announcement effect.

Second, as reported in the earlier studies, governance variables are interdependently determined. It could be more appropriate to use a structural equation model to investigate the dynamics of governance variables.

Third, in the literature we find other multifactor models to detect long-term abnormal returns. In this study we did not investigate other types of multifactor models except for Fama-French three-factor regression model.

Fourth, we use reported values for unexercised CEO stock options as published in the management information circulars as a proxy for CEO option value. Other standard methodologies (for example, the binomial model or the Black-Scholes model) could be used to value CEO stock options. 
Fifth, the dataset used to investigate the impact of takeover premiums on short- and longterm performance is quite limited (92 cases). The results are also puzzling. This issue should be investigated further with a larger dataset.

\subsection{Suggestions for Future Research}

The limitations discussed in the previous section would lead to future research. A more comprehensive dataset can be used to test the hypotheses.

Second, contrary to our expectations, we found that the market reacted more favorably to unrelated acquisitions, cross-border acquisitions, and deals with higher takeover premiums. These issues can be investigated further to check the robustness of the results.

Third, we used only six years of data to test the governance variables. With more emphasis on corporate governance in recent years, one could undertake a more comprehensive and longitudinal study to investigate the role of governance variables in

the domain of M\&A research. Further, structural equation modeling can be employed to check for interdependence among governance variables and to measure some of the unobservable constructs such as CEO hubris.

Fourth, in order to get a clearer picture about the relative importance of the variables used in the analysis, one could use the "variable importance analysis" techniques. 
Finally, there can be a logical extension to this study to investigate the change in the degree of risk and liquidity of an acquiring firm's shares subsequent to an acquisition event. 


\section{REFERENCES}

Agrawal, A., \& Jaffe, J. F. (2000). The post-merger performance puzzle. Advances in Mergers and Acquisitions, 1, 7-41.

Agrawal, A., Jaffe, J. F. \& Mandelker, G. N. (1992). The post-merger performance of acquiring firms: A re-examination of an anomaly. The Journal of Finance, 47(4), 1605-1621.

Agresti, A. (1996). An introduction to categorical data analysis. New York: John Wiley.

Ambrose, B. W., \& Megginson, W. L. (1992). The role of asset structure, ownership structure and take-over defences in determining acquisition likelihood. Journal of Financial and Quantitative Analysis, 27(4), 575-589.

Andrade, G., \& Stafford, E. (2003). Investigating the economic role of mergers. Journal of Corporate Finance, 10, 1-36.

Andrade, G., Mitchell, M., \& Stafford, E. (2001). New evidence and perspectives on mergers. Journal of Economic Perspectives, 15(2), 103-120.

Andre, P., Kooli, M., \& L'Her, J. (2004). The long-run performance of mergers and acquisitions: Evidence from the Canadian stock market. Financial Management, Winter, 27-43.

Asquith, P. (1983). Merger bids, uncertainty and stockholder returns. Journal of Financial Economics, 11, 51-83.

Asquith, P., Bruner, R., and Mullins, D. Jr. 1983. The Gains to Bidding Firms From Merger. Journal of Financial Economics, 11(1): 121-139.

Barber, B. M., \& Lyon, J.,D. (1997). Detecting long-run abnormal stock returns: The empirical power and specification of test statistics. Journal of Financial Economics, 43, 341-372.

Bae, K., Kang, J., \& Kim, J. (2002). Tunneling or value added? Evidence from mergers by Korean business groups. Journal of Finance, 57(6), 2695-2740.

Beaty, R. P., \& Zajac, E. J. (1994). Managing incentives, monitoring, and risk bearing: A study of executive compensation, ownership, and board structure in initial public offerings. Administrative Science Quarterly, 39, 313-335.

Bebchuk, L. A., \& Fried, J. M. (2003). Executive compensation as an agency problem. Journal of Economic Perspectives, 17, 71-92. 
Berkovitch, E., \& Narayanan, M. P. (1993). Motives for takeovers: An empirical investigation. Journal of Financial and Quantitative Analysis, 28(3), 347-362.

Berle, A., \& Means. G. (1932). The modern corporation and private property. New York: Macmillan.

Bhagat, S., \& Black, B. (2002). The non-correlation between board independence and long term firm performance. Journal of Corporation Law, 27, 231-274.

Bhagat, S., \& Jefferis, R. H. Jr. (2002). The econometrics of corporate governance studies. Cambridge, MA: The MIT Press.

Bizjak, J., Brickley, J. A., \& Coles, J. L. (1993). Stock-based incentive compensation and investment behavior. Journal of Accounting and Economics, 16, 349-372.

Black, F. (1972). Capital market equilibrium with restricted borrowing. Journal of Business, 45(3), 444-454.

Bradley, M., \& Jarrell, G. A. (1988). Comment on are acquiring-firm shareholders better off after an acquisition? In J. C. Coffee, Jr., L. Lowenstein, \& S. Rose-Ackerman (Eds.), Knights, raiders and targets: The impact of the hostile takeover, New York: Oxford University Press.

Bradley, M., Desai, A., \& Kim, E. H. (1988). Synergistic gains from corporate acquisitions and their division between the stockholders of target and acquiring firms. Journal of Financial Economics, 21(1), 3-40.

Brav, A., \& Gompers, P. A. (1997). Myth or reality? The long-run underperformance of initial public offerings: Evidence from venture- and nonventure-capital-backed companies. Journal of Finance, 52, 1791-1820.

Brealey, R. A., Myers, S. C., Marcus, A. J., Maynes, E. M., \& Mitra, D. (2006). Fundamentals of corporate finance (3rd Can. ed.), Toronto, ON, Canada: McGraw-Hill Ryerson.

Brook, Y., Hendershott, R. J., \& Lee, D. (2000). Corporate governance and recent consolidation in the banking industry. Journal of Corporate Finance, 6, 141-164.

Brown, S. J., \& Warner, J. B. (1985). Using daily stock returns: The case of event studies. Journal of Financial Economics, 14, 3-31.

Bruner, R. (2003). Does $M \& A$ pay (Working Paper)? Charlottesville, VA: Darden Graduate School of Business, University of Virginia. 
Bryan, S., Hwang, L., \& Lilien, S. (2000). CEO stock-based compensation: An empirical analysis of incentive-intensity, relative mix, and economic determinants. The Journal of Business, 73(4), 661-693.

Byrd, J., \& Hickman, K. (1992). Do outside directors monitor managers? Evidence from tender offer bids. Journal of Financial Economics, 32, 195-207.

Carpenter, M. A., \& Sanders, W. G. (2002). Top management team compensation: The missing link between CEO pay and firm performance? Strategic Management Journal, 23, 367-375.

Calvet, A. L., \& Lefoll, J. (1987). Information asymmetry and wealth effect of Canadian corporate acquisitions. Financial Review, 22(4), 415-431.

Chang, S. (1998). Takeovers of privately held targets, methods of payment, and bidder returns. Journal of Finance, 53, 773-784.

Comment, R., \& Schwert, G. W. (1995). Poison or placebo? Evidence on the deterrence and wealth effects of modern antitakeover measures. Journal of Financial Economics, 39, 3-43.

Conyon, M. J., \& Peck, S. I. (1998). Board control, remuneration committees, and top management compensation. Academy of Management Journal, 41(2), 146-157.

Cordeiro, J. J., \& Veliyath, R. (2003). Beyond pay for performance: A panel study of the determinants of CEO compensation. American Business Review, 21(1), 56-66.

Core, J. E., Holthausen, R. W., \& Larcker, D. F. (1999). Corporate governance, chief executive officer compensation, and firm performance. Journal of Financial Economics, 51, 371-406.

Cotter, J., Shivdasani, A., \& Zenner, M. (1997). Do independent directors enhance target shareholder wealth during tender offers? Journal of Financial Economics, 43, 195-218.

Crawford, D., \& Lechner, T. A. (1996). Takeover premiums and anticipated merger gains in the U.S. market for corporate control. Journal of Business Finance \& Accounting, 23(5/6), 807-829.

Delong, G. (2001). Stockholder gains from focusing versus diversifying bank mergers. Journal of Financial Economics, 59(2), 221-252.

Dennis, D., \& McConnell, J. (1986). Corporate mergers and security returns. Journal of Financial Economics, 16(2), 143-187. 
Dodds, J. C., \& Quek, J. P. (1985). Effect of mergers on the share price movement of the acquiring firms: A UK study. Journal of Business Finance and Accounting, 12, 285-296.

Dong, M., Hirshleifer, D., Richardson, S., \& Teoh, S. H. (2002). Does investor misevaluation drive the takeover market (Working Paper)? Columbus, OH: The Ohio State University.

Eckbo, B. E. (1986). Mergers and the market for corporate control: The Canadian evidence. Canadian Journal of Economics, 14(2), 236-260.

Eckbo, B. E., \& Thorburn, K. S. (2000). Gains to bidder firms revisited: Domestic and foreign acquisitions in Canada. Journal of Financial and Quantitative Analysis, $35(1), 1-25$.

Eckbo, B. E., Giammarino, R., \& Heinkel, R. (1990). Asymmetric information and the medium of exchange in takeovers: Theory and tests. Review of Financial Studies, $3,651-676$.

Eckbo, B. E., Maksimovic, Y., \& Williams, J. (1990). Consistent estimation of crosssectional models in event studies. Review of Financial Studies, 3, 343-365.

Fama, E. F. (1998). Market efficiency, long-term returns, and behavioral finance. Journal of Financial Economics, 49, 283-306.

Fama, E. F., \& French, K. R. (1995). Size and book-to-market factors in earnings and returns. Journal of Finance, 50, 131-155.

Fama, E. F., \& French, K. R. (1997). Industry costs of equity. Journal of Financial Economics, 43, 153-193.

Fama, E. F., \& Jensen, M. C. (1983). Separation of ownership and control. Journal of Law and Economics, October, 301-326.

Fama, E. F., \& MacBeth, J. D. (1973). Risk, return, and equilibrium: Empirical tests. Journal of Political Economy, 81, 607-636.

Fishman, M. (1989). Preemptive bidding and the role of the medium of exchange in acquisitions. Journal of Finance, 44, 41-57.

Franks, J., \& Mayer, C. (1996). Hostile takeovers and the correction of managerial failure. Journal of Financial Economics, 40, 163-181.

Franks, J., Harris, R., \& Titman, S. (1991). The postmerger share-price performance of acquiring firms. Journal of Financial Economics, 29(1), 81-96. 
Fuller, K., Netter, J., \& Stegemoller, M. (2002). What do returns to acquiring firms tell us? Evidence from firms that make many acquisitions. The Journal of Finance, 57(4), 1763-1793.

Gaughan, P. A. (2002). Mergers, Acquisitions, and Corporate Restructurings (3rd ed.). New York: John Wiley \& Sons.

Ghosh, A. (2001). Does operating performance really improve following corporate acquisitions? Journal of Corporate Finance, 7, 151-178.

Ghosh, A., \& Lee, C. J. (2000). Abnormal returns and expected managerial performance of target firms. Financial Management, Spring, 40-52.

Gilson, R. J., Scholes, M. S., \& Wolfson, M. A. (1988). Taxation and the dynamics of corporate control: The uncertain case for tax-motivated acquisitions. In J. C. Coffee, Jr., L. Lowenstein, \& S. Rose-Ackerman, (Eds.), Knights, raiders and targets: The impact of the hostile takeover (pp. 271-299). New York: Oxford University Press.

Gompers, P. A., \& Lerner, J. (2003). The really long-run performance of initial public offerings: The pre-Nasdaq evidence. The Journal of Finance, 58(4), 1355-1392.

Gort, M. (1969). An economic disturbance theory of mergers. Quarterly Journal of Economics, 83, 624-642.

Gregory, A. (1997). An examination of the long run performance of UK acquiring firms. Journal of Business Finance and Accounting, 24, 971-1002.

Grinblatt, M., \& Titman, S. (2002). Financial markets and corporate strategy (2nd ed.). New York: McGraw Hill Irwin.

Grinstein, Y., \& Hribar, P. (2004). CEO compensation and incentives: Evidence from M\&A bonuses. Journal of Financial Economics, 73, 119-143.

Hansen, R. G., \& Lott, J. (1996). Externalities and corporate objectives in a world with diversified shareholders/ consumers. Journal of Financial and Quantitative Analysis, 31, 43-68.

Harford, J. (1999). Corporate cash reserves and acquisitions. The Journal of Finance, 54(6), 1969-1997.

Hasbrouck, J. (1985). The characteristics of takeover targets. Journal of Banking and Finance, 9, 351-362.

Hayn, C. (1989). Tax attributes as determinants of shareholder gains in corporate acquisitions. Journal of Financial Economics, 23, 121-153. 
Hayward, M. L. A., \& Hambrick, D. C. (1997). Explaining the premiums paid for large acquisitions: Evidence of CEO hubris. Administrative Science Quarterly, 42, 103127.

Healy, P. M., Palepu, K. G., \& Ruback, R. S. (1992). Does corporate performance improve after mergers? Journal of Financial Economics, 31, 135-175.

Heinkel, R., \& Kraus, A. (1988). Measuring event impacts in thinly traded stocks. Journal of Financial and Quantitative Analysis, 23(1), 71-88.

Hermalin, B. E., \& Weisbach, M. S. (2003). Boards of directors as an endogenously determined institution: A survey of the economic literature. FRBNY Economic Policy Review, April, 7-26.

Herman, E., \& Lowenstein, L. (1988). The efficiency effects of hostile takeovers. In J. C. Coffee, Jr., L. Lowenstein, and S. Rose-Ackerman, (Eds.). Knights, raiders and targets: The impact of the hostile takeover (pp. 211-240). New York: Oxford University Press.

Hietala, P., Kaplan, S., \& Robinson, D. (2000). What is the price of hubris? Using takeover battles to infer overpayments and synergies (Working paper). University of Chicago, Chicago.

Holland, K. M., \& Hodgkinson, L. (1994). The pre-announcement share price behavior of UK takeover targets. Journal of Business Finance \& Accounting, 21(4), 467-489.

Holmstrom, B., \& Kaplan, S. N. (2001). Corporate governance and merger activity in the United States: Making sense of the 1980s and 1990s. Journal of Economic Perspectives, 15(2), 121-144.

Hosmer, D. W., \& Lemeshow, S. (2000). Applied Logistic Regression. New York: John Wiley.

Houston, J., James, C., \& Ryngaert, M. (2001). Where do merger gains come from? Bank mergers from the perspective of insiders and outsiders. Journal of Financial Economics, 60(2/3), 285-331.

Ikanberry, D., Lakonishok, J., \& Vermaelen, T. (1995). The underreaction to open market share repurchases. Journal of Financial Economics, 39, 181-208.

Jaffe, J. (1974). Special information and insider trading. Journal of Business, 47, 411428.

Jarrell, G., \& Poulsen, A. (1989). The returns to acquiring firms in tender offers: Evidence from three decades. Financial Management, 18(3), 12-19. 
Jarrell, G. A., Brickley, J. A., \& Netter, J. M. (1988). The market for corporate control: The empirical evidence since 1980. Journal of Economic Perspectives, 2, 49-68.

Jensen, M. (1986). Agency costs of free cash flow, corporate finance and takeovers. American Economic Review, 76, 323-329.

Jensen, M. (1993). The modern industrial revolution, exit, and the failure of internal control systems. Journal of Finance, 48(3), 831-880.

Jensen, M., \& Meckling, W. (1976). Theory of the firm: Managerial behavior, agency cost, and ownership structure. Journal of Financial Economics, 3, 305-360.

Jensen, M. C., \& Ruback, R. S. (1983). The market for corporate control: The scientific evidence. Journal of Financial Economics, 11, 5-50.

Jog, V. M., \& Riding, A. L. (1988). Post-acquisition performance of partially acquired Canadian firms. In R. S. Khemani, D. M. Shapiro, \& W. T. Stanbury (Eds.). Mergers, corporate concentration and power in Canada (pp. 233-252). Alberta: The Institute for Research on Public Policy.

Kennedy, V. A., \& Limmack, R. J. (1996). Takeover activity, CEO turnover, and the market for corporate control. Journal of Business Finance and Accounting, 23(2), 267-293.

Kirby, J. (2004, February 16-29). The trouble with mergers. Canadian Business, 65-68.

Kohers, N., \& Kohers, T. (2000). The value creation potential of high-tech mergers. Financial Analysts Journal, May/June, 40-50.

Kohers, N., \& Kohers, T. (2001). Takeovers of technology firms: Expectations vs. reality. Financial Management, Autumn, 35-54.

Kothari, S. P., \& Warner, J. B. (1997). Measuring long-horizon security performance. Journal of Financial Economics, 43, 301-339.

Kothari, S. P., \& Warner, B. (2005). Econometrics of event studies. In B. Espen Eckbo, (Ed.). Handbook of corporate finance: Empirical corporate finance (pp. 1-23, chapter 1). Elsvier/North-Holland.

Lakonishok, J., Shleifer, A., \& Vishny, R. W. (1994). Contrarian investment, extrapolation, and risk. Journal of Finance, 49, 1541-1578.

Lang, L., Stulz, R., \& Walking, R. (1989). Managerial performance, Tobin's Q, and the gains from successful tender offers. Journal of Financial Economics, 24(1), 137154. 
Langetieg, T. (1978). An application of a three-factor performance index to measure stockholders gains from merger. Journal of Financial Economics, 6(4), 365-384.

Lee, P. M., \& O'Neill, H. M. (2003). Ownership structures and R\&D investments of U.S. and Japanese firms: Agency and stewardship perspectives. Academy of Management Journal, 46(2), 212-225.

Limmack, R. J. (1991). Corporate mergers and shareholder wealth effects: 1977-1986. Accounting and Business Research, 21(83), 239-251.

Linn, S. C., \& McConnell, J. J. (1983). An empirical investigation of the impact of 'antitakeover' amendments on common stock prices. Journal of Financial Economics, 11, 361-399.

Lipton, M., \& Lorsch, J. (1992). A modest proposal for improved corporate governance. Business Lawyer, 48(1), 59-77.

Loderer, C., \& Martin, K. (1990). Corporate acquisitions by listed firms: The experience of a comprehensive sample. Financial Management, Winter, 17-33.

Loderer, C., \& Martin, K. (1992). Postacquisition performance of acquiring firms. Financial Management, 21(3), 69-79.

Loughran, T., \& Ritter, J. (2000). Uniformly least powerful tests of market efficiency. Journal of Financial Economics, 55, 361-390.

Loughran, T., \& Vijh, A. M. (1997). Do long-term shareholders benefit from corporate acquisitions? Journal of Finance, 52(5), 1765-1790.

Lyon, J. D., Barber, B. M., \& Tsai, C. (1999). Improved methods for tests of long-run abnormal stock returns. The Journal of Finance, 54(1), 165-201.

Magenheim, E. B., \& Mueller, D. C. (1988). Are acquiring-firm shareholders better off after an acquisition? In J. C. Coffee, Jr., L. Lowenstein, \& S. Rose-Ackerman (Eds.). Knights, raiders and targets: The impact of the hostile takeover. New York: Oxford University Press.

Mahoney, J. M., \& Mahoney, J. T. (1993). An empirical investigation of the effect of corporate charter anti-takeover amendments on stockholder wealth. Strategic Management Journal, I4(1), 17-31.

Mak, Y. T., \& Li, Y. (2001). Determinants of corporate ownership and board structure: Evidence from Singapore. Journal of Corporate Finance, 7, 235-256. 
Malatesta, P. H. (1983). The wealth effect of merger activity and the objective functions of merging firms. Journal of Financial Economics, 11, 155-181.

Mandelker, G. (1974). Risk and return: The case of merging firms. Journal of Financial Economics, 1, 303-335.

Mangel, R., \& Singh, H. (1993). Ownership structure, board relationships and CEO compensation in large U.S. corporations. Accounting and Business Research, 23(91A), 339-350.

Maquieira, C. P., Megginson, W. L., \& Nail, L. (1998). Wealth creation versus wealth redistributions in pure stock-for-stock mergers. Journal of Financial Economics, $48,3-33$.

Martin, K. (1996). The method of payment in corporate acquisitions, investment opportunities, and managerial ownership. Journal of Finance, 51, 1227-1246.

Martin, K. J., \& McConnell, J. J. (1991). Corporate performance, corporate takeovers, and management turnover. The Journal of Finance, 46(2), 671-687.

Masse, I., Hanrahan, R., \& Kushner, J. (1990). The effect of the method of payment on stock returns in Canadian tender offers and merger proposals for both target and bidding firms. Quarterly Journal of Business and Economics, 29(4), 102-112.

McWilliams, A., \& Siegel, D. (1997). Event studies in management research: Theoretical and empirical issues. Academy of Management Journal, 40(3), 626-657.

Mehran, H., \& Tracy, J. (2001). The effect of employee stock options on the evolution of compensation in the 1990s. FRBNY Economic Policy Review, December, 17-34.

Mitchell, M. L., \& Mulherin, J. H. (1996). The impact of industry shocks on takeover and restructuring activity. Journal of Financial Economics, 41, 193-229.

Mitchell, M. L., \& Stafford, E. (2000). Managerial decisions and long-term stock price performance. Journal of Business, 73(3), 287-329.

Moeller, S., Schlingemann, F. P., \& Stulz, R. M. (2003). Do shareholders of acquiring firms gain from acquisitions (Working paper)? Ohio: Ohio State University.

Morck, R., Schleifer, A., \& Vishny, R. (1989). Alternative mechanisms for corporate control. American Economic Review, 79(4), 842-852.

Morck, R., Shleifer, A., \& Vishny, R. W. (1990). Do managerial objectives drive bad acquisitions? Journal of Finance, 4, 3148. 
Morck, R., Shleifer, A., \& Vishny, R. (1988). Management ownership and market valuation: An empirical analysis. Journal of Financial Economics, 20, 293-315.

Mulherin, J. H. (2000). Incomplete acquisitions and organizational efficiency (Working Paper). PA: Pennsylvania State College.

Mulherin, J. H., \& Boone, A. L. (2000). Comparing acquisitions and divestures. Journal of Corporate Finance, 6, 117-139.

Myers, S., \& Majluf, N. (1984). Corporate financing and investment decisions when firms have information investors do not have. Journal of Financial Economics, $87,355-374$.

Myers, S. C., \& Nicholas, S. M. (1984). Corporate financing and investment decisions when firms have information that investors do not have. Journal of Financial Economics, 13, 187-221.

Narula, R., \& Hagendoom, J. (1999). Innovating through strategic alliances: Moving towards international partnership and contractual agreements. Technovation, 19, 283-294.

Narula, R., \& Sadowski, B. (2002). Technological catch-up and strategic technology partnering in developing countries. International Journal of Technology Management, 23(6), 599-617.

Opler, T., Pinkowitz, L., Stulz, R., \& Williamson, R. (1999). The determinants and implications of corporate holdings of liquid assets. Journal of Financial Economics, 52, 3-46.

Palepu, K. G. (1986). Predicting takeover targets: A methodological and empirical analysis. Journal of Accounting and Economics, 8(1), 3-37.

Powel, R. G. (1997). Modelling takeover likelihood. Journal of Business Finance and Accounting, 24(7/8), 1009-1030.

Rau, P. R., \& Vermaelen, T. (1998). Glamour, value and the post-acquisition performance of acquiring firms. Journal of Financial Economics, 49, 223-253.

Ravenscraft, D., \& Scherer, F. M. (1987). Mergers, selloffs and economic efficiency. Washington, DC: The Brookings Institution.

Roll, R. (1986). The hubris hypothesis of corporate takeovers. Journal of Business, 59, 197-216.

Schwert, G. W. (2000). Hostility in takeovers: In the eyes of the beholder? The Journal of Finance, 55(6), 2599-2640. 
Servaes, H. (1991). Tobin's Q and the gains from takeovers. Journal of Finance, 46(1), 409-419.

Shleifer, A., \& Vishny, R. W. (1986). Large shareholders and corporate control. Journal of Political Economy, 95, 461-488.

Smith, B. F., \& Amako-Adu, B. (1993). Empirical analysis of exempt takeover offers on the Toronto Stock Exchange. Canadian Journal of Administrative Sciences, 10(4), 344-352.

Smith, C. W., \& Watts, R. L. (1992). The investment opportunity set and corporate financing, dividend, and compensation policies. Journal of Financial Economics, $32,263-292$.

Smith, R., \& Kim, J. (1994). The combined effects of free cash flow and financial slack on bidder and target stock returns. Journal of Business, 67(2), 281-310.

St-Pierre, J. (1994). Takeover bid resistance and the managerial welfare hypothesis: Evidence from the Canadian market. Canadian Journal of Administrative Sciences, $11(1), 86-96$.

Subrahmanyam, V., Rangan, N., \& Rosenstein, S. (1997). The role of outside directors in bank acquisitions. Financial Management, 26(3), 23-36.

Sundaramurthy, C., Mahoney, J. M., \& Mahoney, J. T. (1997). Board structure, antitakeover provisions, and stockholder wealth. Strategic Management Journal, $18(3), 231-245$.

Thomas, H. M. (1997). Discussion of modelling takeover likelihood. Journal of Business Finance and Accounting, 24(7/8), 1031-1035.

Travlos, N. G. (1987). Corporate takeover bids, methods of payment, and bidding firms' stock returns. The Journal of Finance, 42(4), 943-963.

Vijh, A. M. (1994). S\&P 500 trading strategies and stock betas. Review of Financial Studies, 7, 215-251.

Walker, M. (2000). Corporate takeovers, strategic objectives, and acquiring-firm shareholder wealth. Financial Management, 29(1), 3-66.

Werner, S., \& Tosi, H. L. (1995). Other people's money: The effects of ownership on compensation strategy and managerial pay. Academy of Management Journal, $38(6), 1672-1691$. 
Weston, J. F. (1970). The nature and significance of conglomerate firms. St. John's Law Review, 44(Special Edition), 66-80.

Wu, Y. (2000). Honey, CalPERS shrunk the board (Working paper). Chicago, IL: University of Chicago.

Yermack, D. (1995). Do corporations award CEO stock options effectively? Journal of Financial Economics, 39, 237-269.

Yuce, A., \& Ng, A. (2005). Effects of private and public Canadian mergers. Canadian Journal of Administrative Sciences, 22(2), 111-124. 


\section{APPENDIX A: STRUCTURAL CHANGES IN M\&A MARKET IN THE 1990S}

There has been significant change in the Mergers and Acquisitions market over the last two decades. The structural changes that are identified in literature are as follows:

Shift in focus from unrelated to related acquisitions. Until the late 1960 s, diversification was a major motive for M\&A. In the 1970s the focus started to change. In the 1990 s we see an ever-increasing percentage of mergers taking place in the same industry (Andrade et al., 2001).

Change in methods of payment. Mergers in the 1990s are characterized by the overwhelming use of stock as a method of payment. In the US, about $70 \%$ of all deals in the 1990 s involved stock compensation, with $58 \%$ being entirely stock-financed. These numbers are approximately 50\% more than in the 1980s (Andrade et al., 2001).

Use of leverage. In the $1980 \mathrm{~s}$, takeovers were characterized by a heavy use of leverage (LBOs) and consequently, there was an increase in junk-bond issues. This trend virtually disappeared in the 1990s and the use of equity became prominent again (Holmstrom \& Kaplan, 2001).

Hostile takeover versus friendly mergers. In the 1980s, there was a high level of hostility in the takeover market. Between $20 \%$ and $40 \%$ of tender offers were contested by 
incumbent managers in that period, whereas in the $1990 \mathrm{~s}, 15 \%$ or fewer were contested (Andrade et. al., 2001; Holmstrom \& Kaplan, 2001).

Focus on corporate governance issues. There was a change in corporate governance mechanisms in the 1990 s with shareholders monitoring management more closely. Shareholdings of professional, institutional investors increased substantially in the 1990s. From 1980 to 1996 , large institutional investors nearly doubled the share of the stock market they owned from under $30 \%$ to over $50 \%$ (Holmstrom \& Kaplan, 2001).

Industry deregulation. Many industries have been deregulated since the mid-1980s. Deregulation potentially removes barriers to merging and consolidating thus fueling the M\&A market (Andrade et. al., 2001; Mitchell \& Mulherin, 1996).

Competition level and high-tech influence. In the 1990s, there was an increased level of foreign competition (Mitchell \& Mulherin, 1996) and takeover activities in high-tech industries soared as acquirers sought to capitalize on the growth potential offered by high-tech companies (Kohers \& Kohers, 2000). 


\section{APPENDIX B: STATE OF M\&A LITERATURE: A SNAPSHOT}

The conventional research domain for M\&A issues includes (i) the short term performance of target shares and bidder shares and the relevant factors affecting performance; (ii) the long term performance of bidding firms; (iii) the characteristics of target firms and bidding firms; (iv) the motives for takeover; (v) anti-takeover measures and relevant impact; and (vi) industry shock and its impact on M\&A activity. It would be a difficult task to summarize all the findings of numerous studies in the different fields of M\&A in a small space; however, in order to have an overview of the area and a glimpse of the empirical results, a short summary is presented in Figure B.1 and discussed in the following paragraphs.

\section{Figure B.1 M\&A Research Domain}

Characteristics of

target/ bidding

firms

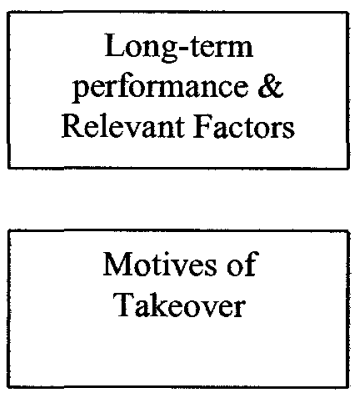

Short-term performance \& Relevant Factors

Industry shock and its impact 
Short-term performance. Andrade, Mitchell and Stafford (2001) point out that the most statistically reliable evidence on whether mergers create value for shareholders comes from traditional short-window event studies around an announcement date. Most of the studies have shown that mergers create value for shareholders on an aggregate basis, (i.e., combining the effects on target shareholders and bidder shareholders) and most of the gains accrue to the target shareholders.

Long-term performance. The empirical results on long-term performance (generally 3 to 5 years after acquisition) for the acquiring firms do not portray a positive image. Most of the studies report a negative long-term performance based on stock returns (for example, see Loughran \& Vijh, 1997). However, it should be noted that there is no overall consensus on this issue. Healy and Palepu (1992) find that the operating performance of acquiring firms does not decrease over the long run, whereas Mitchell and Stafford (2000) question the validity of the methodology used in long-term performance studies. They show that once necessary adjustments are applied to conventional methodologies, the systematic long-term underperformance of acquiring firms disappears.

Characteristics of target/ bidding firms. Another set of studies attempts to determine the characteristics of target firms (for example, see Brook et. al., 2000; Dietrich and Sorenson, Palepu, 1986; 1984; Powell, 1997). Generally, the factors identified include low asset turnover, low past profitability, low market-to-book value, and the presence of outside directors and institutional investors. However, Thomas (1997) has argued that 
such firm-level characteristics are not consistent over time. There is no comprehensive study on the characteristics of bidding firms.

Motives for takeovers. Researchers and practitioners have identified a number of factors as motives for mergers and acquisitions. The main motives, as cited in the literature, include synergy, growth, diversification, and CEO hubris (Berkovitch \& Narayanan, 1993; Gaughan, 2002). Other factors include industry clustering and shocks (Andrade et. al., 2001; Mitchell and Mulherin, 1996), taxation (Gilson et. al., 1988; Hayn, 1989), and availability of free cash flow (Harford, 1999; Jensen, 1988; Smith and Kim, 1994).

Anti-takeover measures and the relevant impact. A set of studies has focused on various anti-takeover measures adopted by firms and their impact on shareholder value. Common anti-takeover measures include poison pill provisions, supermajority merger approval provisions, classified board provisions, fair price amendments, reduction in cumulative voting provisions, and anti-greenmail provisions (Sundaramurthy et. al., 1997). Several earlier studies indicate that the market reacts negatively to the adoption of anti-takeover provisions (Mahoney \& Mahoney, 1993). Sundaramurthy et. al. (1997) show that separation of the CEO and chairperson of the board positions reduces the negative effect, whereas higher outsider representation on the board increases the negative effect. Other studies, including Comment and Schwert (1995), find that anti-takeover measures increase the bargaining power of target firms and leads to higher takeover premiums for selling shareholders, and that these measures do not prevent many transactions. 
Industry shock and its impact. Finally, a relatively smaller set of papers have indicated that it is important to consider the industry effects and "shocks" while analyzing mergers and acquisitions events. These papers argue that mergers can be precipitated by industrywide forces, such as a reaction to a change in the industry structure. Jensen (1993) proposes that most merger activities since the mid-1970s have been caused by technological and supply shocks, which resulted in excess productive capacity in many industries. Jensen (1993) argues that mergers are the principal way of removing this excess capacity, as faulty internal governance mechanisms prevent firms from "shrinking" themselves. Andrade and Stafford (2003) provide empirical support for such arguments. Mitchell and Mulherin (1996) document that a substantial portion of the takeover activity in the 1980 s can be explained by industries reacting to major shocks, such as deregulation, increased foreign competition, financial innovations, and oil price shocks. 


\section{Part 1: Summary of the Short-Term Performance Studies for Bidding Firms' Shareholders (Presented in Table C.1 and C.2)}

Table C.1 Studies Reporting Negative Abnormal Returns to Acquirers

\begin{tabular}{|c|c|c|c|c|c|c|}
\hline Study & $\begin{array}{c}\text { Cumulative } \\
\text { Abnormal Returns }\end{array}$ & $\begin{array}{l}\text { Sample } \\
\text { Size }\end{array}$ & $\begin{array}{l}\text { Sample } \\
\text { Period }\end{array}$ & $\begin{array}{c}\text { Event } \\
\text { Window } \\
\text { (days) }\end{array}$ & $\begin{array}{l}\text { \% Pos. } \\
\text { Returns }\end{array}$ & Notes \\
\hline Langetieg (1978) & $-1.61 \%$ & 149 & $1929-69$ & $(-120,0)$ & $47.6 \%$ & $\begin{array}{l}\text { Mergers; uses effective date as } \\
\text { event date }\end{array}$ \\
\hline $\begin{array}{l}\text { Asquith, Bruner, \& } \\
\text { Mullins (1987) }\end{array}$ & $-0.85 \% * *$ & 343 & $1973-83$ & $(-1,0)$ & $41 \%$ & \\
\hline $\begin{array}{l}\text { Morck, Shleifer, \& } \\
\text { Vishny (1990) }\end{array}$ & $-0.70 \%$ & 326 & $1975-87$ & $(-1,1)$ & $41.4 \%$ & $\begin{array}{l}\text { Measured return by comparing } \\
\text { change in bidder MV to MV of } \\
\text { target's equity }\end{array}$ \\
\hline $\begin{array}{l}\text { Franks, Harris, \& Titman } \\
\text { (1991) }\end{array}$ & $-1.45 \%$ & 399 & $1975-84$ & $(-5,5)$ & $\mathrm{N} / \mathrm{A}$ & $\begin{array}{l}\text { Mergers and tenders offers; } \\
\text { segment data available on means } \\
\text { of payment and competition }\end{array}$ \\
\hline Servaes (1991) & $-1.07 \% * *$ & 384 & $1972-87$ & $(-1$, Close $)$ & $\mathrm{N} / \mathrm{A}$ & $\begin{array}{l}\text { Mergers and tender offers; } \\
\text { segment data by payment } \\
\text { method }\end{array}$ \\
\hline Byrd \& Hickman (1992) & $-1.2 \% * *$ & 128 & $1980-87$ & $(-1,0)$ & $33 \%$ & \\
\hline $\begin{array}{l}\text { Healy, Palepu, \& Ruback } \\
\text { (1992) }\end{array}$ & $-2.2 \%$ & 50 & $1979-84$ & $(-5,5)$ & $\mathrm{N} / \mathrm{A}$ & $\begin{array}{l}50 \text { Largest U.S. mergers during } \\
\text { period }\end{array}$ \\
\hline $\begin{array}{l}\text { Berkovitch \& Narayanan } \\
\text { (1993) }\end{array}$ & $-\$ 10 \mathrm{MM}$ & 330 & $1963-88$ & $(-5,5)$ & $49.4 \%$ & Tender offers \\
\hline $\begin{array}{l}\text { Eckbo \& Thorburn } \\
(2000)\end{array}$ & $-0.30 \%$ & 390 & $1964-83$ & $(-40,0)$ & $\mathrm{N} / \mathrm{A}$ & $\begin{array}{l}\text { U.S. Acquirers of Canadian } \\
\text { Targets }\end{array}$ \\
\hline Mulherin \& Boone (2000) & $-0.37 \%$ & 281 & $1990-99$ & $(-1,+1)$ & $\mathrm{N} / \mathrm{A}$ & \\
\hline $\begin{array}{l}\text { Mitchell \& Stafford } \\
(2000)\end{array}$ & $\begin{array}{l}-0.14 \% * *(a) \\
-0.07 \%\end{array}$ & $\begin{array}{l}366 \\
366\end{array}$ & $1961-93$ & $(-1,0)$ & $\mathrm{N} / \mathrm{A}$ & $\begin{array}{l}\text { Fama and French 3-Factor } \\
\text { Model, applied to monthly } \\
\text { returns }\end{array}$ \\
\hline Walker (2000) & $\begin{array}{l}-0.84 \% * *(b) \\
-0.77 \%\end{array}$ & $\begin{array}{l}278 \\
278\end{array}$ & $1980-96$ & $(-2,+2)$ & $\begin{array}{l}41.4 \% \\
46.4 \%\end{array}$ & \\
\hline DeLong (2001) & $-1.68 \% * *$ & 280 & $1988-95$ & $(-10,1)$ & $33.6 \%$ & $\begin{array}{l}\text { Deals in which at least one party } \\
\text { is a bank. }\end{array}$ \\
\hline Houston et al. (2001) & $\begin{array}{l}-4.64 \% * *(1985-90) \\
-2.61 \%(1991-96) \\
-3.47 \% * * \text { (all) }\end{array}$ & $\begin{array}{l}27 \\
37 \\
64\end{array}$ & $1985-96$ & $(-4,1)$ & $\mathrm{N} / \mathrm{A}$ & $\begin{array}{l}\text { Deals in which both parties are } \\
\text { banks. }\end{array}$ \\
\hline
\end{tabular}

Notes: Unless otherwise noted, event date is the announcement date of merger/bid.

** Significance at the 0.95 confidence level or better.

(a) Top return is based on an equal-weighted benchmark portfolio. Bottom return is based on a value-weighted benchmark portfolio.

(b) Top return is a return adjusted for market average returns. Bottom return is adjusted for return on a matched firm.

Source: Bruner (2003) 
Table C.2 Studies Reporting Zero or Positive Abnormal Returns to Acquirers

\begin{tabular}{|c|c|c|c|c|c|c|}
\hline Study & $\begin{array}{l}\text { Cumulative Abnormal } \\
\text { Returns }\end{array}$ & $\begin{array}{l}\text { Sample } \\
\text { Size }\end{array}$ & $\begin{array}{l}\text { Sample } \\
\text { Period }\end{array}$ & $\begin{array}{l}\text { Event } \\
\text { Window } \\
\text { (days) }\end{array}$ & $\begin{array}{l}\% \text { Pos. } \\
\text { Returns }\end{array}$ & Notes \\
\hline Asquith (1983) & $\begin{array}{l}+0.20 \% \text { Successful } \\
+0.50 \% \text { Unsuccessful }\end{array}$ & $\begin{array}{l}196 \\
89\end{array}$ & $1962-76$ & $(-1,0)$ & N.A. & Mergers only. Daily data. \\
\hline $\begin{array}{l}\text { Asquith, Bruner, \& Mullins } \\
\text { (1983) }\end{array}$ & $\begin{array}{l}+3.48 \% * * \text { Successful } \\
+0.70 \% \text { Unsuccessful }\end{array}$ & $\begin{array}{l}170 \\
41\end{array}$ & 1963-79 & $(-20,+1)$ & N.A. & Mergers only. Daily data. \\
\hline Eckbo (1983) & $\begin{array}{l}+0.07 \% \text { Successful } \\
+1.20 \% * * \text { Unsuccessful }\end{array}$ & $\begin{array}{c}102 \\
57 \\
\end{array}$ & $1963-78$ & $(-1,0)$ & N.A. & Mergers only. Daily data. \\
\hline Malatesta (1983) & $+0.90 \%$ Successful & 256 & 1969-74 & $(0,0)$ & N.A. & Mergers only. Monthly data. \\
\hline $\begin{array}{l}\text { Dennis \& McConnell } \\
(1986)\end{array}$ & $\begin{array}{l}-0.12 \%(-1,0) \\
+3.24 \%(-6,+6)^{* *}\end{array}$ & 90 & $1962-80$ & $(-1,0)$ & $52 \%$ & \\
\hline $\begin{array}{l}\text { Jarrell, Brickley, \& Netter } \\
\text { (1987) }\end{array}$ & $+1.14 \% * *$ & 440 & $1962-85$ & $(-10,5)$ & N/A & $\begin{array}{l}\text { Tender offers only; subperiod } \\
\text { data available for } 1962-69,70- \\
79,80-85 ; \text { acquirer returns have } \\
\text { decreased from }+4 \% \text { to }-1 \%\end{array}$ \\
\hline $\begin{array}{l}\text { Bradley, Desai, \& Kim } \\
(1988)\end{array}$ & $+1 \% * *$ & 236 & $1963-84$ & $(-5,5)$ & $47 \%$ & $\begin{array}{l}\text { Tender offers only; subperiod } \\
\text { data available for } 7 / 63-6 / 68 \text {, } \\
7 / 68-12 / 80,1 / 81-12 / 84 ; \text { acquirer } \\
\text { returns have decreased from } \\
+4 \% \text { to }-3 \% \text { over time }\end{array}$ \\
\hline Jarrell, \& Poulsen (1989) & $+0.92 \% * *$ & 461 & $1963-86$ & $(-5,5)$ & N/A & Tender offers only \\
\hline $\begin{array}{l}\text { Lang, Stulz, \& Walkling } \\
\text { (1989) }\end{array}$ & $0 \%$ & 87 & $1968-86$ & $(-5,5)$ & N/A & Tender offers only \\
\hline Loderer \& Martin (1990) & $\begin{array}{l}+1.72 \% * * 1966-68 \\
+0.57 \% * * 1968-80 \\
-0.07 \% 1981-84\end{array}$ & $\begin{array}{c}970 \\
3401 \\
801\end{array}$ & $1966-84$ & $(-5,0)$ & $\mathrm{N} / \mathrm{A}$ & $\begin{array}{l}\text { Mergers and tenders offers; } \\
\text { segment data available on size of } \\
\text { acquisition }\end{array}$ \\
\hline Smith \& Kim (1994) & $\begin{array}{l}+0.50 \% \\
-0.23 \% \\
\end{array}$ & 177 & $1980-86$ & $\begin{array}{l}(-5,5) \\
(-1,0)\end{array}$ & $\begin{array}{l}49.2 \% \\
76.2 \% \\
\end{array}$ & $\begin{array}{l}\text { Successful and unsuccessful } \\
\text { tender offers }\end{array}$ \\
\hline Maquieira, et al. (1998) & $\begin{array}{l}+6.14 \% * * \text { non- } \\
\text { conglomerate deals } \\
-4.79 \% \text { conglomerate }\end{array}$ & $\begin{array}{l}55 \\
47 \\
\end{array}$ & $1963-96$ & $(-60,60)$ & $\begin{array}{l}61.8 \% \\
36.2 \%\end{array}$ & $\begin{array}{l}\text { Study of returns in conglomerate } \\
\text { and non-conglomerate stock-for- } \\
\text { stock deals }\end{array}$ \\
\hline Eckbo \& Thorburn (2000) & $+1.71 \% * *$ & 1261 & $1964-83$ & $(-40,0)$ & N/A & $\begin{array}{l}\text { Canadian acquirers of Canadian } \\
\text { targets }\end{array}$ \\
\hline Mulherin (2000) & $+0.85 \% * *$ & 161 & $1962-97$ & $(-1,0)$ & $49 \%$ & $\begin{array}{l}\text { A sample of incomplete } \\
\text { acquisitions. }\end{array}$ \\
\hline Kohers \& Kohers (2000) & $\begin{array}{l}1.37 \% * * \text { cash deals } \\
1.09 \% * * \text { stock } \\
1.26 \% \text { whole sample }\end{array}$ & $\begin{array}{c}961 \\
673 \\
1634 \\
\end{array}$ & 1987.96 & $(0,1)$ & $\mathrm{N} / \mathrm{A}$ & $\begin{array}{l}\text { Sample of mergers among high- } \\
\text { tech firms. }\end{array}$ \\
\hline $\begin{array}{l}\text { Moeller, Schlingemann, \& } \\
\text { Stulz (2003) }\end{array}$ & $\begin{array}{l}+1.103 \% * * \text { All } \\
+1.496 \% * * \text { Private } \\
-1.02 \% * * \text { Public } \\
+2.003 \% * * \text { Subsidiary }\end{array}$ & 12,023 & $1980-01$ & $(-1,+1)$ & N/A & $\begin{array}{l}\text { Tested the difference in bidder's } \\
\text { returns at acquiring private } \\
\text { company, public company, or } \\
\text { subsidiary of public company. }\end{array}$ \\
\hline Kohers \& Kohers (2001) & $+0.92 \%$ & 304 & $1985-95$ & $(-1,0)$ & N/A & Sample of technology mergers \\
\hline $\begin{array}{l}\text { Fuller, Netter, and } \\
\text { Stegemoller (2002) }\end{array}$ & $\begin{array}{l}+1.77 \% * * \text { All } \\
+2.74 \% * * 1^{\text {st }} \text { time } \\
\text { bidders }\end{array}$ & 3,135 & $1990-00$ & $(-2,+2)$ & $\mathrm{N} / \mathrm{A}$ & \\
\hline
\end{tabular}

Notes: Unless otherwise noted, event date is announcement date of merger/bid. ** Significance at the 0.95 confidence level or better.

Source: Bruner (2003) 


\section{Part 2: Short Term Performance Studies of Target Firms}

There has been overwhelming support in the literature that shareholders of target firms enjoy positive returns around the takeover announcement date. Only short-term returns are investigated for the target firms following a takeover announcement, as the target firms would cease to operate in the event of a successful merger or takeover. Relevant theories/conjectures and empirical evidence are presented below:

\section{Theory/Conjectures}

The following reasons are cited for the positive returns of target firm shareholders following the announcement of a merger or a takeover attempt.

Agency problem. Agency theory predicts that shareholders will gain as a result of disciplinary actions taken against managers who perform poorly (Palepu, 1986). Therefore, if the target firms have agency problems, and if their management' performance is expected to be poor in the future, the stock returns for the target company should increase subsequent to a merger announcement (Ghosh \& Lee, 2000).

Synergy motive. The most commonly cited reason for acquisitions is the prospective synergies of the deal. The synergy motive assumes that the managers of the targets and the acquirers maximize shareholder wealth and would engage in takeover activity only if it results in gains to both sets of shareholders. Therefore, it follows that the measured 
gains to both the target and the acquirer shareholders would be positive (Berkovitch \& Naryanan, 1993).

Multiple bidders and bargaining power. If the target has some bargaining power, either because it can resist the acquirer or because there is competition among potential acquirers for the target, then the target gain would increase (Berkovitch \& Naryanan, 1993) because bidding firms need to pay higher premiums in such instances.

\section{Empirical evidence}

As stated earlier, the empirical evidence shows that the shareholders of target firms generally gain from takeover deals. These results are consistent across the studies carried out for different time periods (for example, see Bradley et al., 1988; Eckbo \& Thorburn, 2000; Franks et al., 1991; Houston et al., 2001; Jensen \& Ruback, 1983; Langetieg, 1978; Mulherin 2000; Smith \& Kim, 1994;). A detailed summary of the studies investigating the short-term performance of target firms is presented in Table C.3. 
Table C.3 Studies Reporting Abnormal Returns to Target Firm Shareholders

\begin{tabular}{|c|c|c|c|c|c|c|}
\hline Study & $\begin{array}{c}\text { Cum. Abnormal } \\
\text { Returns } \\
(\% \text { or avg } \$ / \text { acq) } \\
\end{array}$ & $\begin{array}{l}\text { Sample } \\
\text { Size }\end{array}$ & $\begin{array}{l}\text { Sample } \\
\text { Period }\end{array}$ & $\begin{array}{l}\text { Event } \\
\text { Window } \\
\text { (days) }\end{array}$ & $\begin{array}{l}\text { \% Pos. } \\
\text { Returns }\end{array}$ & Notes \\
\hline Langetieg (1978) & $+10.63 \% * *$ & 149 & $\begin{array}{l}1929- \\
1969\end{array}$ & $(-120,0)$ & $71.6 \%$ & $\begin{array}{l}\text { Mergers; uses } \\
\text { effective date as } \\
\text { event date }\end{array}$ \\
\hline Bradley, Desai, \& Kim (1988) & $+31.77 \% * *$ & 236 & $\begin{array}{l}1963- \\
1984\end{array}$ & $(-5,5)$ & $95 \%$ & $\begin{array}{l}\text { Tender offers only; } \\
\text { sub-period data } \\
\text { available for } 7 / 63- \\
6 / 68,7 / 68-12 / 80 \text {, } \\
1 / 81-12 / 84 ; \text { acquirer } \\
\text { returns have } \\
\text { increased from }+19 \% \\
\text { to }+35 \% \text { over time }\end{array}$ \\
\hline Dennis \& McConnell (1986) & $8.56 \% * *$ & 76 & $\begin{array}{l}1962- \\
1980\end{array}$ & $(-1,0)$ & $70 \%$ & \\
\hline Jarrell \& Poulsen (1989) & $+28.99 \% * *$ & 526 & $\begin{array}{l}1963- \\
1986\end{array}$ & $(-20,10)$ & N/A & Tender offers only \\
\hline Lang, Stulz, \& Walkling (1989) & $+40.3 \% * *$ & 87 & $1968-86$ & $(-5,5)$ & N/A & Tender offers only \\
\hline Franks, Harris, \& Titman (1991) & $+28.04 \% * *$ & 399 & $\begin{array}{l}1975- \\
1984\end{array}$ & $(-5,5)$ & N/A & $\begin{array}{l}\text { Mergers and tenders } \\
\text { offers; segment data } \\
\text { available on means of } \\
\text { payment and } \\
\text { competition }\end{array}$ \\
\hline Servaes (1991) & $+23.64 \% * *$ & 704 & $\begin{array}{l}1972- \\
1987\end{array}$ & $(-1$, Close $)$ & N/A & $\begin{array}{l}\text { Mergers and tender } \\
\text { offers; segment data } \\
\text { by payment method }\end{array}$ \\
\hline Healy, Palepu, \& Ruback (1992) & $+45.6 \% * *$ & 50 & $\begin{array}{l}1979- \\
1984\end{array}$ & $(-5,5)$ & N/A & $\begin{array}{l}\text { Largest U.S. mergers } \\
\text { during period }\end{array}$ \\
\hline Berkovitch \& Narayanan (1993) & $+\$ 130.1 \mathrm{MM}^{* *}$ & 330 & $\begin{array}{l}1963- \\
1988\end{array}$ & $(-5,5)$ & $95.8 \%$ & Tender offers \\
\hline Smith, Kim (1994) & $\begin{array}{l}+30.19 \% * * \\
+15.84 \% * *\end{array}$ & 177 & $\begin{array}{l}1980- \\
1986\end{array}$ & $\begin{array}{l}(-5,5) \\
(-1,0)\end{array}$ & $\begin{array}{l}96.0 \% \\
91.3 \%\end{array}$ & $\begin{array}{l}\text { Successful and } \\
\text { unsuccessful tender } \\
\text { offers }\end{array}$ \\
\hline $\begin{array}{l}\text { Maquieira, Megginson \& Nail } \\
\text { (1998) }\end{array}$ & $\begin{array}{l}+41.65 \% * * \\
\text { conglomerate } \\
+38.08 \% * * \text { non- } \\
\text { congl. }\end{array}$ & $\begin{array}{l}47 \\
55\end{array}$ & $\begin{array}{l}1963- \\
1996\end{array}$ & $(-60,60)$ & $\begin{array}{l}61.8 \% \\
83.0 \%\end{array}$ & $\begin{array}{l}\text { Study of returns for } \\
\text { conglomerate and } \\
\text { non-conglomerate } \\
\text { stock-for-stock } \\
\text { mergers. }\end{array}$ \\
\hline Eckbo \& Thorburn (2000) & $+7.45 \%$ ** & 332 & $1964-83$ & $(-40,0)$ & N/A & Canadian targets only \\
\hline Mulherin \& Boone (2000) & $+21.2 \% * *$ & 376 & $\begin{array}{l}1990- \\
1999\end{array}$ & $(-1,+1)$ & $\mathrm{N} / \mathrm{A}$ & \\
\hline Mulherin (2000) & $+10.14 \% * *$ & 202 & $\begin{array}{l}1962- \\
1997\end{array}$ & $(-1,0)$ & $76 \%$ & $\begin{array}{l}\text { A sample of } \\
\text { incomplete } \\
\text { acquisitions. }\end{array}$ \\
\hline DeLong (2001) & $+16.61 \% * *$ & 280 & $\begin{array}{l}1988- \\
1995\end{array}$ & $(-10,1)$ & $88.6 \%$ & $\begin{array}{l}\text { Studied deals where } \\
\text { at least one party is a } \\
\text { bank. }\end{array}$ \\
\hline Houston et al. (2001) & $\begin{array}{l}+15.6 \% * *(85-90) \\
+24.60 \% * *(91-96) \\
+20.80 \% * * \text { (all })\end{array}$ & $\begin{array}{l}27 \\
37 \\
64 \\
\end{array}$ & $\begin{array}{l}1985- \\
1996\end{array}$ & $(-4,1)$ & N/A & $\begin{array}{l}\text { Deals in which both } \\
\text { parties are banks. }\end{array}$ \\
\hline
\end{tabular}

Notes: Unless otherwise noted, event date is announcement date of merger/bid.

** Significance at the 0.95 confidence level or better.

Source: Bruner (2003) 


\section{APPENDIX D: SUMMARY OF THE LONG TERM PERFORMANCE STUDIES}

\section{Table D.1 Key Studies in Long-Term Post Merger Performance}

\begin{tabular}{|c|c|c|c|c|}
\hline Study & Data & Methodology & $\begin{array}{l}\text { Event Date/ Post } \\
\text { merger period }^{\mathrm{a}}\end{array}$ & Results \\
\hline $\begin{array}{l}\text { Mandelker } \\
\text { (1974) }\end{array}$ & $\begin{array}{l}241 \text { NYSE mergers over } \\
1941-1962\end{array}$ & $\begin{array}{l}\text { Fama-MacBeth (1973) } \\
\text { two factor regression } \\
\text { model }\end{array}$ & $\begin{array}{l}\text { Completion date; } \\
40 \text { Months }\end{array}$ & $\begin{array}{l}\text { Negative abnormal return in } \\
40 \text { months after event date; } \\
\text { but statistically not } \\
\text { significant }\end{array}$ \\
\hline $\begin{array}{l}\text { Langetieg } \\
\text { (1978) }\end{array}$ & $\begin{array}{l}\text { 149 NYSE mergers over } \\
1929-1969\end{array}$ & $\begin{array}{l}\text { Four models to get } \\
\text { abnormal returns; Also } \\
\text { used control firm } \\
\text { approach }\end{array}$ & $\begin{array}{l}\text { Completion date; } \\
70 \text { Months }\end{array}$ & $\begin{array}{l}\text { Large negative returns using } \\
\text { first approach; smaller and } \\
\text { statistically insignificant } \\
\text { negative return using } \\
\text { control firm approach. }\end{array}$ \\
\hline Asquith (1983) & $\begin{array}{l}196 \text { NYSE bidders with } \\
\text { successful mergers and } 87 \\
\text { NYSE bidders with } \\
\text { unsuccessful mergers } \\
(1962-1976)\end{array}$ & $\begin{array}{l}\text { Beta control portfolio } \\
\text { to get excess return }\end{array}$ & $\begin{array}{l}\text { Completion date; } \\
240 \text { days following } \\
\text { outcome date }\end{array}$ & $\begin{array}{l}-7.2 \% \text { cumulative excess } \\
\text { return for the successful } \\
\text { bidders and }-9.6 \% \\
\text { cumulative excess returns } \\
\text { for the unsuccessful bidders. }\end{array}$ \\
\hline $\begin{array}{l}\text { Malatesta } \\
\text { (1983) }\end{array}$ & $\begin{array}{l}256 \text { U.S. acquiring firms } \\
\text { over } 1969-1974\end{array}$ & $\begin{array}{l}\text { Market Model; } \\
\text { Separate calculation } \\
\text { for pre- and post-event } \\
\text { Beta }\end{array}$ & $\begin{array}{l}\text { Announcement } \\
\text { Date; } \\
+1 \text { to }+6 \text { months } \\
+7 \text { to }+12 \text { month }\end{array}$ & $\begin{array}{l}-5.4 \% \text { abnormal return for } \\
+1 \text { to }+6 \text { months and }-2.2 \% \\
\text { abnormal returns for the }+7 \\
\text { to }+12 \text { months. }\end{array}$ \\
\hline $\begin{array}{l}\text { Bradley \& } \\
\text { Jarrell (1988) }\end{array}$ & $\begin{array}{l}78 \text { U.S. firms over 1976- } \\
1981 .\end{array}$ & $\begin{array}{l}\text { Beta control portfolio } \\
\text { to get excess return }\end{array}$ & $\begin{array}{l}\text { Announcement } \\
\text { Date; } \\
36 \text { months }\end{array}$ & $\begin{array}{l}-16 \% \text { abnormal return but } \\
\text { statistically insignificant. }\end{array}$ \\
\hline Limmack (1991) & $\begin{array}{l}448 \text { completed bids and } 81 \\
\text { abandoned bids over } \\
1977-1986 \text { (UK market } \\
\text { data) }\end{array}$ & $\begin{array}{l}\text { Three control methods: } \\
\text { market model, adjusted } \\
\text { beta model and Index } \\
\text { model }\end{array}$ & $\begin{array}{l}\text { Announcement } \\
\text { Date; } \\
24 \text { months }\end{array}$ & $\begin{array}{l}\text { Completed bids: } \\
-14.96 \%,-4.67 \% \& \&-7.43 \% \\
\text { Abandoned bids: } \\
-24.2 \%,-26.25 \% \& \&-7.38 \%\end{array}$ \\
\hline $\begin{array}{l}\text { Franks, Harris, } \\
\text { \& Titman } \\
\text { (1991) }\end{array}$ & $\begin{array}{l}399 \text { NYSE/AMEX } \\
\text { acquisitions over } 1975- \\
1984 \text {. }\end{array}$ & $\begin{array}{l}\text { Eight-portfolio model } \\
\text { (preferred) }\end{array}$ & $\begin{array}{l}\text { Announcement } \\
\text { Date; } \\
36 \text { months }\end{array}$ & $\begin{array}{l}\text { Insignificant abnormal } \\
\text { return both for event time } \\
\text { and calendar time approach. }\end{array}$ \\
\hline $\begin{array}{l}\text { Agrawal et. al. } \\
\text { (1992) }\end{array}$ & $\begin{array}{l}937 \text { mergers and } 227 \\
\text { tender offers over } 1955 \text { to } \\
1987 \text { (NYSE /AMEX } \\
\text { firms) }\end{array}$ & $\begin{array}{l}\text { Size and Beta adjusted } \\
\text { portfolio formation and } \\
\text { regression }\end{array}$ & $\begin{array}{l}\text { Completion date; } \\
60 \text { months }\end{array}$ & $\begin{array}{l}-10.26 \% \text { significant } \\
\text { abnormal return for mergers } \\
\text { in } 60 \text { months; No significant } \\
\text { abnormal return for tender } \\
\text { offers. }\end{array}$ \\
\hline Gregory (1997) & $\begin{array}{l}452 \text { U.K. firms over } 1984 \\
\text { to } 1992\end{array}$ & Six different methods & $\begin{array}{l}\text { Completion date; } \\
24 \text { months }\end{array}$ & $\begin{array}{l}-11.8 \% \text { to }-18 \% \text { statistically } \\
\text { significant abnormal return } \\
\text { depending on method used. }\end{array}$ \\
\hline $\begin{array}{l}\text { Loughran \& } \\
\text { Vijh (1997) }\end{array}$ & $\begin{array}{l}947 \text { NYSE /AMEX/ } \\
\text { NASDAQ firms } \\
\text { ( } 788 \text { merger \& } 135 \text { tender } \\
\text { offer) }\end{array}$ & $\begin{array}{l}\text { Buy hold abnormal } \\
\text { return (after size and } \\
\text { BV/MV adjustment) }\end{array}$ & $\begin{array}{l}\text { Completion date; } \\
60 \text { months }\end{array}$ & $\begin{array}{l}-15.9 \% \text { significant abnormal } \\
\text { return for mergers in } 60 \\
\text { months; No significant } \\
\text { abnormal return for tender } \\
\text { offers. }\end{array}$ \\
\hline $\begin{array}{l}\text { Rau \& } \\
\text { Vermaelen } \\
(1998)\end{array}$ & $\begin{array}{l}2823 \text { mergers and } 316 \\
\text { tender bids over } 1980- \\
1991\end{array}$ & $\begin{array}{l}\text { Control portfolio with } \\
\text { size and BV/MV } \\
\text { adjustments }\end{array}$ & $\begin{array}{l}\text { Completion date; } \\
36 \text { months }\end{array}$ & $\begin{array}{l}-4 \% \text { significant abnormal } \\
\text { return for mergers in } 36 \\
\text { months; }+8.56 \% \text { significant } \\
\text { abnormal return for tender } \\
\text { offers. }\end{array}$ \\
\hline $\begin{array}{l}\text { Mitchell \& } \\
\text { Stafford }(2000)\end{array}$ & $\begin{array}{l}2,767 \text { acquisitions over } \\
1961-1993\end{array}$ & $\begin{array}{l}\text { Three methods: } \\
\text { BHAR; Calendar time } \\
\text { portfolio with Fama- }\end{array}$ & $\begin{array}{l}\text { Completion date; } \\
36 \text { months }\end{array}$ & $\begin{array}{l}\text { No significant abnormal } \\
\text { return once cross-sectional } \\
\text { dependence is taken into }\end{array}$ \\
\hline
\end{tabular}




\begin{tabular}{|l|l|l|l|l|}
\hline \multicolumn{1}{|c|}{ Study } & \multicolumn{1}{|c|}{ Data } & \multicolumn{1}{|c|}{ Methodology } & $\begin{array}{l}\text { Event Date/ Post } \\
\text { merger period }^{\text {a }}\end{array}$ & \multicolumn{1}{|c|}{ Results } \\
\hline $\begin{array}{l}\text { Moeller, } \\
\text { Schlingemann } \\
\text { and Stulz (2003) }\end{array}$ & $\begin{array}{l}12,023 \text { acquisitions (U.S. } \\
\text { data) over 1980-2001 } \\
\text { Calendar time portfolio } \\
\text { analysis }\end{array}$ & $\begin{array}{l}\text { Two methods: BHAR; } \\
\text { and Calendar time } \\
\text { portfolio formation }\end{array}$ & Completion date; & $\begin{array}{l}\text { BHAR: -16.02\% significant } \\
\text { abnormal return over 3-yr. } \\
\text { Calendar time: No } \\
\text { significant abnormal return. }\end{array}$ \\
\hline $\begin{array}{l}\text { Andre, Kooli, } \\
\text { and L'Her } \\
\text { (2004) }\end{array}$ & $\begin{array}{l}\text { 267 Canadian acquisitions } \\
\text { over 1980-2000 }\end{array}$ & $\begin{array}{l}\text { Calendar time portfolio } \\
\text { with Fama-French } \\
\text { Regression }\end{array}$ & $\begin{array}{l}\text { Completion date; } \\
\text { No significant abnormal } \\
\text { return for all cases. } \\
\text { Negative abnormal return } \\
\text { for non-overlapping cases } \\
\text { (143 cases). }\end{array}$ \\
\hline
\end{tabular}

Note: a - Number of months or days considered following a merger event.

A brief discussion of the relevant studies is presented below:

Agrawal and Jaffe (2000) have provided a comprehensive summary of the extant literature covering the long-term performance of firms following a merger and acquisition event. They discuss 22 studies based on U.S. and U.K. data. It appears that there is no significant study using Canadian data that investigates the long term performance following takeover events. In the following section, we present a brief but systematic review of the prominent studies.

Mandelker (1974) is the first to treat the financial consequences of mergers in a systematic way by determining merger completion date precisely and calculating abnormal returns (or residuals) relative to a benchmark (as cited in Agrawal \& Jaffe, 2000). Mandelker analyzed 241 mergers that took place during 1941-1962. All the acquiring and acquired firms considered in the study were listed on the New York Stock Exchange (NYSE). Although the study's emphasis was on short-term effects surrounding the merger event, Mandelker did examine the post event performance up to 40 months following the merger date. The study employs the two factor Fama-MacBeth (1973) 
regression model to determine abnormal returns. The results show cumulative average abnormal returns (CAARs) of -0.014 over the 40 months following merger completion. Though the results reveal an economically significant drop, it is found to be statistically insignificant.

Langetieg (1978) examines 149 mergers between NYSE listed firms between 1929 and 1969 and employs two different approaches to performing the analyses. First, Langetieg uses four measures of abnormal return including the Capital Asset Pricing Model (CAPM), Black's (1972) two-factor model, and two industry indices. Regardless of the measures, Langetieg reports large negative returns over three intervals following the mergers ( +1 to +12 months; +13 to +24 months; and +25 to +70 months). As Agrawal and Jaffe (2000) report, summation over the three periods results in a cumulative abnormal performance over +1 to +70 months between $-22.3 \%$ and $-26.15 \%$ depending on the benchmark reference. Second, Langetieg (1978) uses a control firm approach and calculates abnormal performance as the difference between the acquiring firm's performance using one of the four measures above and the control firm's performance using the same measure. Langetieg then compares these returns and finds that the "paired difference" results are still predominantly negative, but not statistically significant.

Asquith (1983) analyzes the abnormal stock price performance of 196 successful and 87 unsuccessful NYSE firms that engaged in merger bids over the period 1962 to1976. The study uses daily return data as opposed to monthly return data used in the Mandelker (1974) and Langetieg (1978) study and it allows the researcher to examine the entire 
merger process from 480 trading days before a merger bid until 240 trading days after a merger bid. Daily abnormal returns are calculated as the difference between the return on the merging firm and the return on a control portfolio with a similar beta. To form this control portfolio, all securities on the NYSE and American Stock Exchange (ASE) are ranked once a year according to their betas and placed into one of the 10-decile portfolios. Asquith (1983) reports a cumulative excess return of $-7.2 \%$ over the 240 days following the outcome date for the "successful" bidders and $-9.6 \%$ for the "unsuccessful" bidders. However, Asquith mentions a valid methodological challenge by pointing out that the merging of two independent firms with different betas may cause a problem with the calculation of excess returns, that is, excess returns for the merged firms are calculated for a time using the beta of only the bidding firms.

Malatesta (1983) examines 256 acquiring firms over the period 1969-1974 as reported in United States Federal Trade Commission (FTC) Statistical Reports on mergers and acquisitions. These acquisitions include only target firms with an asset size greater than 10 million USD. The author uses the market model to calculate abnormal return and preevent data to estimate pre-event $\alpha$ 's and $\beta$ 's. Post-event data are used to estimate postevent $\alpha$ 's and $\beta$ 's. The study reports significant negative abnormal returns for acquiring firms over the periods ( +1 to +6 months) and ( +7 to +12 months) of $-5.4 \%$ and $-2.2 \%$ respectively. However, in explaining such results, Malatesta (1983) indicates that this could result from "“arbitrary details of experimental design" (p. 180) and thus "drawing strong conclusions concerning returns of acquiring firms is inappropriate" (p. 180). 
Magenheim and Muller (1988) examine 77 NYSE/ASE firms that completed takeovers worth at least $\$ 15$ million over the period 1976-1981. Like Malatesta (1983), they also use a market model but divide the sample into two sub-groups: 51 of the acquisitions as mergers and 26 as tender offers. Their results show Cumulative Average Abnormal Return (CAARs) over the first three years after the announcement to be $-24.37 \%$ and $+6.3 \%$ respectively for the two groups (calculated by Agrawal and Jaffe, 2000).

Bradley and Jarrell (1988) examine the same 78 U.S. acquiring firms over the period 1976 to 1981 as used in the Magenheim and Muller (1988) study. They criticize the use of monthly data to estimate market model parameters (as used by Malatesta, 1983 and by Magenheim and Muller, 1988) by arguing that the estimates would be inefficient and nonstationary. Indeed, financial economists have long argued that if the true abnormal performance were non-zero during the estimation period, the measurement of abnormal performance in the forecast period would be biased (Agrawal \& Jeffe, 2000). Bradley and Jarrell (1988) use a similar methodology as Asquith (1983) and find a statistically insignificant CAAR of $-16 \%$ over the first three post-acquisition years.

Limmack (1991) examines the post-acquisition performance of acquirers in 448 completed bids and 81 abandoned bids from 1977 to 1986 . Limmack uses three control methods to identify the abnormal returns of the acquiring companies. First, the author uses the market model developed by Fama, Fisher, Jensen and Roll during 1969 with $\alpha$ and $\beta$ estimated from return data over -67 to -7 months relative to the announcement month. Second, adjusted betas supplied by the London Business School Risk 
Management Service (RMS) are used in the market model. Third, residuals (abnormal returns) are calculated using an Index Model, i.e., by assuming an alpha of " 0 " and beta of "1" for all securities. The study reports cumulative abnormal returns (CAR) for acquiring firms for the period from the bid month to 24 months following the outcome month separately for completed bids and abandoned bids. For completed bids, reported CARs are $-14.96 \%,-4.67 \%$ and $-7.43 \%$ for the market model, the adjusted beta model and the index model respectively; these are all statistically significant. Limmack also presents value-weighted returns, which are smaller in magnitude and only the market model CAR is statistically significant. For abandoned bids, reported CARs are $-24.2 \%,-$ $26.25 \%$ and $-7.38 \%$ for the market model, the adjusted beta model and the industry index model respectively; these are all statistically significant. Value-weighted abnormal performance is similar in magnitude but the CAR for the adjusted beta model is statistically insignificant.

Franks, Harris, and Titman (1991) investigate 399 acquisitions and tender offers from 1975-1984 where both the acquirer and target were NYSE- or AMEX-listed firms. This landmark study is the first research study to focus on long-term post merger returns, measuring abnormal returns relative to four benchmarks, the CRSP equally-weighted index, the CRSP value-weighted index, a 10-factor model and an eight-portfolio model. The last benchmark was their preference and consisted of four portfolios based on firm size, three based on dividend yields, and one based on past returns. Their results for a 36month post announcement date window indicate significant negative abnormal returns using the equally weighted benchmark, significantly positive abnormal returns using the 
value- weighted benchmark, and statistically insignificant results using the ten-factor or eight-portfolio approach. Franks, et al. conclude that previous reports of significant negative abnormal returns were the result of benchmark errors rather than systematic mispricing by investors at the time of acquisitions.

Using a nearly exhaustive sample of mergers (937 mergers and 227 tender offers) over 1955 to 1987 between NYSE acquirers and NYSE/AMEX targets, Agrawal, Jaffe and Mandelker (1992) measure post-acquisition performances after adjusting for the firm size effect as well as beta risk. The authors use two methods to measure long-run abnormal returns that consider adjustments for the size effect and beta. Betas are measured over +1 to +60 months relative to the month of the merger completion in order to account for changes in firm beta after acquisition. They find that stockholders of the acquiring firms suffer a statistically significant wealth loss of about $10 \%$ over the five years following the merger completion. However, long-run abnormal returns following tender offers are found to be insignificant under both methods. This conclusion runs contrary to Franks et. al's (1991) results which, as shown by Agrawal et. al. (1992), are specific to the former study's sample time period and are also due to their mixing of tender offers with mergers.

Gregory (1997) presents a comprehensive work on long-run returns considering 452 U.K. acquisitions over the period 1984 to 1992 . In all of the cases, bid values are at least greater than 10 million pounds. The author calculates abnormal returns for acquiring firms using six different models (CAPM, Dimson and Marsh risk and size adjustment, Simple size control portfolio, Multi-index model, value weighted multi-index model and 
Fama-French three factor model). Gregory reports a range of cumulative abnormal returns for acquiring firms ranging between $-11.8 \%$ and $-18 \%$ over the two years following the month of the merger completion; all the results are statistically significant.

Loughrun and Vijh (1997) measure the post-acquisition performance of 947 firms that made acquisitions over the period 1970 to 1989 where both the target and the acquirer were traded on NYSE, AMEX or NASDAQ. For the first time in this area of literature, the authors used the Buy Hold Abnormal Return (BHAR) methodology. This methodology has become increasingly popular for investigating long-run abnormal returns following a corporate event. Under this methodology, Loughrun and Vijh calculate a five-year abnormal return as the difference between the buy and hold return of the acquirer and the buy and hold return of a control firm based on size and the book-tomarket ratio. Like Agrawal et. al. (1992), they also separate mergers (788 cases) from tender offers (135 cases) and find that post-acquisition abnormal returns are significantly negative $(-15.9 \%)$ following mergers but marginally significantly positive following tender offers. The authors also report similar results after removing overlapping cases where the post-acquisition periods overlap for acquisitions of the same acquirer.

Rau and Vermaelen (1998) examine a sample of 2823 mergers and 316 tender offers with the buyer listed on both the Centre for Research in Security Prices (CRSP) NYSE/AMEX/Nasdaq tapes and Compustat. Their sample period covers transactions from January 1980 to December 1991. Adjusting for both firm size and book-to-market ratios, they report acquirers under-perform equally weighted control portfolios with 
similar sizes and book-to-market ratios by $4 \%$ over 3 years from the completion date. Regardless of statistical issues, in their review, Agrawal and Jaffe (2000) note that a $-4 \%$ result over a three year span is not economically significant. Rau and Vermaelen (1998) also find that acquirers in tender offers earn a significant and positive abnormal return of $8.56 \%$. This is not consistent with previous statistically insignificant findings and likely reflects differences in sample composition (including a higher proportion of smaller firms) and the noted methodological bias.

Mitchell and Stafford (2000) examine long-run performance following three corporate events: takeovers, equity issues and equity repurchases. Their sample of takeovers consists of 2,767 acquisitions (including both mergers and tender offers) of CRSP-listed firms from 1961 to 1993 . They use three different methods to calculate abnormal return. First, BHAR is calculated for three years using appropriate size and BV/MV portfolios. Second, Fama-French regression analysis is performed after forming calendar time portfolios (discussed in the next section). Third, portfolios are formed each month using the sample of all acquirers with an acquisition within the last three years. Abnormal return in each calendar month is calculated as the difference between the realized return on the event portfolio and an estimate of its expected return. The latter is estimated from either the Fama-French three-factor model or the appropriate size and BV/MV portfolio. For all the three approaches, Mitchell and Stafford (2000) have used equally-weighted and value-weighted portfolios. Once cross-sectional dependence is taken into consideration, the BHAR approach does not give any significant abnormal returns. For the other two methods, the authors also report similar insignificant abnormal returns once 
value- weighted portfolios are considered. Based on these results, Mitchell and Stafford (2000) argue that all the earlier results on long-run abnormal returns need to be considered carefully and that earlier findings of long-run underperformance are most likely resulting from misspecification of different methods.

Moeller, Schlingemann and Stulz (2003) examine a sample of 12,023 acquisitions by public firms from 1980 to 2001 that are listed in the Securities Data Company's (SDC) U.S. Mergers and Acquisitions Database. Almost half of the sample involves acquisitions of private firms $(5,583)$. The authors have employed both "calendar time portfolio" and "event time" approaches in evaluating the long-term performance. They also examine long-term returns for sub-samples selected according to firm size, target organizational form, and form of payment. In the case of the calendar time portfolio approach, they report a monthly abnormal return of $-0.041 \%$ for acquiring companies, which is statistically and economically insignificant. They also find that private firm acquisitions by large firms have positive long-term abnormal returns, while private firm acquisitions by small firms have negative long-term abnormal returns. In the case of the event time approach, they calculate the three-year buy-and-hold abnormal returns (BHAR), following the approach of Barber and Lyon (1997). By using an equally weighted BHAR technique, they find that acquiring firms have a negative abnormal return $(-16.02 \%)$ over a three-year period, which is economically significant. However, we note that Moeller et al. (2003) do not make corrections for possible cross-sectional dependence among the various events taking place within a short period of time (Mitchell \& Stafford, 2000). This may lead to a significant abnormal return in the case of event time analysis. 
Andre, Kooli and L'Her (2004) examine a sample of 267 acquisitions by Canadian acquirers from 1980 to 2000 , using different calendar-time approaches. They report a significant negative abnormal return for Canadian acquirers over the three-year postevent period considering the non-overlapping cases (143 cases). However, no significant abnormal return is observed while they consider all cases together (overlapping and nonoverlapping cases). Further, they report that glamour acquirers, equity financed deals, cross-border acquisitions, and related acquisitions exhibit underperformance in the longrun. 


\section{APPENDIX E: EMPIRICAL STUDIES INVESTIGATING THE CHARACTERISTICS OF TARGET FIRMS}

Dietrich and Sorenson (1984) examine 30 target firms from four industries (food and beverage, chemical, electronic, and transportation) from 1969 to 1973 and contrast them with a matched sample of 60 firms distributed equally in the same four industries. Their results show that an important factor affecting the firm's attractiveness is the inability of the incumbent management to generate sales per unit of assets (i.e., asset turnover). Further, they find that this low turnover must be accompanied by one or more of the following in order to increase the probability of a merger: low payout, low financial leverage, high trading volume, and lower market value.

Hasbrouck (1984) attempts to assess the differences in the financial characteristics of 86 target firms and a similar number of non-target firms from 1977 to 1982 using both logit analysis and a case-control methodology in which control groups are matched by size or industry. The results indicate that unregulated non-financial target firms are characterized by a low " $q$ " ratio (market/replacement values) and, to a lesser extent, high current financial liquidity. Measures of financial leverage were not found to be significant. The author also reports that a higher market value for a firm reduces the probability of being taken over at a later stage.

In an influential study that corrects earlier methodological flaws, Palepu (1986) investigates 163 targets and 256 non-target firms over the period of 1971 to 1979 . The 
author reports that inefficiency (expressed by previous stock returns and accounting return), growth-resource imbalance (i.e., low growth, resource rich), and smaller size are likely to increase a firm's probability of becoming a target. The variables of market-tobook ratios and price-earnings ratios have statistically insignificant coefficients, indicating that they are not important determinants of the likelihood of an acquisition. Contrary to expectations, Palepu also finds that if a firm is randomly chosen from an industry in which at least one acquisition occurred during the previous year, that firm is more likely to be a non-target than a target during the current year.

Powell (1997) ${ }^{72}$ uses a sample of UK firms consisting of 411 targets (97 firms subject to a hostile bid and 314 firms subject to a friendly bid) and 532 firms not taken over from the period of 1984 to 1991 . The results show that (i) the characteristics of targets subject to hostile bids that impact on takeover likelihood do not affect the targets subject to friendly bids in the same way, (ii) treating both types of targets as belonging to a single homogeneous group can lead to misleading results.

Using all the bank acquisitions (305 acquisitions) between 1994 and 1996, Brook et al. (2000) find that target banks' board structures do not help determine which banks are likely to become targets. Neither the fraction of outsiders on a bank's board nor having an outside-dominated board differentiates the target banks in their sample. Instead, they find that outside directors/shareholders and blockholders are primarily responsible for encouraging managers to accept an attractive merger offer. This is consistent with the

72 The results of this study are quite elaborate. For detailed results, please refer to Powell (1997, p. 10191025). 
conventional hypothesis that outsiders with sufficient influence would prefer a lucrative takeover deal as it is evident from the literature that target shareholders generally benefit from a merger and acquisition deal (Brook et. al., 2000).

In addition, other studies have concentrated on the performance issues prior to the bid. For example, Martin and McConell (1991) find that hostile targets have poor performance prior to the bid as measured by stock market performance. Morck et. al. (1989) find similar results on hostile takeovers using Tobin's Q and stock market performance. However, studies containing U.K. data do not overwhelmingly support these findings. Franks and Mayer (1996) find that hostile bids in the U.K. do not appear to be directed at poorly performing firms. Holland and Hodgkinson (1994) also show that only leverage is useful in explaining the risk of takeovers. In contrast, using a more comprehensive sample, Kennedy and Limmack (1996) report that poor prior stock market performance is evident in U.K. target firms. 


\section{APPENDIX F: METHODOLOGICAL ISSUES IN SHORT-TERM \\ PERFORMANCE EVALUATION}

Most of the studies in this area use the standard event study methodology developed in the late 1970s and early 1980s. This trend is also evident in recent studies (for example, see Andrade et al., 2001; Fuller et al., 2002; Ghosh \& Lee, 2000; Moeller et al., 2003). Event studies examine the abnormal returns to shareholders in the period surrounding the announcement of a transaction. The abnormal return is simply the raw return less a benchmark of what investors required that day. Typically, the benchmark is the return dictated by the capital asset pricing model (CAPM) or quite simply the return on a large market index, such as S\&P 500 or S\&P/TSX 300. The former variation is known as the "market model" and the later one is known as the "market adjusted model". The mechanism of the event study to be employed in this study is presented towards the end of this Appendix.

Although the event study approach is quite appealing and has dominated the field since the late 1970s, we need to be cautious about the assumptions used in this methodology. McWilliams and Siegel (1997) have presented a vigorous discussion on this issue. The salient points of their concerns are presented below:

- An important assumption of an event study is that markets are efficient. Market efficiency implies that stock prices incorporate all relevant information that is available to market traders and any new information (such as an M\&A 
announcement) will be immediately reflected in the stock price. This assumption is more appropriate for a short event window.

- The second assumption is that the event is totally unanticipated and traders gain information from the announcement only. However, it is possible that an event will have been anticipated or information leaked to the market in advance of a formal announcement. In such situations, an event study will be inappropriate.

- The third assumption is based on the claim that a researcher has isolated the effect of an event from the effects of other events. It is assumed that there are no confounding effects from other events ${ }^{73}$.

- The other important concern expressed by Heinkel and Kraus (1988) is that in the event study, researchers assume that there is no autocorrelation in daily returns. Violating this assumption could have serious implications. Accordingly they have proposed the relevant correction to the test statistic to detect abnormal return.

- Finally, in the event studies, it is generally assumed that there is no cross-sectional dependence among different events. Brown and Warner (1985) have investigated this issue quite extensively and conclude that there is no substantial impact on the outcome even if researchers account for cross-sectional dependence. In general, when there is a positive cross-sectional dependence, failure to make any adjustment to the test statistics would result in a systematic underestimation of the variance of the mean excess return, implying too many rejections of the null hypothesis. However, Brown and Warner (1985) maintain "adjustment for cross-sectional dependence is not always necessary for reasonable test statistic specification. If the degree of

\footnotetext{
${ }^{73}$ Confounding events can include the declaration of dividends, announcement of an impending merger, announcement of a new product, announcement of unexpected earnings, change in key executives etc.
} 
dependence is small, as in studies where event dates are not clustered, ignoring the dependence induces little bias in variance estimates. Furthermore, dependence adjustment can actually be harmful compared to procedures which assume independence" (p. 20).

Choice of event window. As pointed out by Andrade et al. (2001) and Moeller et al. (2003), the three-day window is one of the two most commonly used event windows for merger studies. The other window most commonly used starts before the announcement and ends with the completion of the merger (Moeller et al., 2003). The longer window makes it possible to take into account bid revisions and other actions taken by the bidder in reaction to defensive actions taken by the target (Schwert, 2000). However, a longer window would increase the possibility of the integration of a "confounding effect". The advantage of the shorter window is that its results are typically insensitive to the model chosen for expected returns (Moeller et al., 2003).

\section{Event Study Methodology (Linn \& McConnell, 1983)}

According to the Market Model, ex-post abnormal returns for each security are expressed as:

$$
A R_{j t}=R_{j t}-\left(\bar{\alpha}_{j}+\bar{\beta}_{j} R_{m t}\right)
$$

Where, $R_{j t}$ and $R_{m t}$ are the observed returns for security " $\mathrm{j}$ " and the market portfolio, respectively, in time period " $t$ " relative to the event date of interest. The security specific parameters $\bar{\alpha}_{j}$ and $\bar{\beta}_{j}$ are computed over an estimation period which precedes the event 
date in question, but excludes an arbitrarily chosen time interval in which information concerning the event may have influenced security returns.

To reduce the impact of random estimation errors and other unrelated security specific effects, portfolios are formed in event time such that each daily or monthly portfolio abnormal return is an equally weighted average of the individual security's abnormal returns for that common date.

To determine the statistical significance of the average abnormal return, the following Ztest statistics is used:

$$
Z=\overline{\overline{A R}} / S(\overline{\overline{A R}})
$$

Where, $\quad \overline{\overline{A R}}_{t}=\frac{1}{N}\left(\sum_{j=1}^{N} \overline{A R}_{j t}\right)$

$$
S(\overline{\overline{A R}})=\left(\frac{T-2}{N(T-4)}\right)^{1 / 2}
$$

And,

$$
\text { Adjusted Abnormal Return }\left(A R_{j t}\right)=\overrightarrow{A R}_{j t}=A R_{j t} / S_{t}\left(A R_{j}\right)
$$

Where,

$$
S_{t}\left(A R_{j}\right)=\left\{\operatorname{Var}\left(A R_{j}\right)\left(1+\frac{1}{T}+\frac{\left(R_{m t}-\bar{R}_{m}\right)^{2}}{\sum_{t=1}^{T}\left(R_{m t}-\bar{R}_{m}\right)^{2}}\right)+2 \operatorname{Cov}\left(A R_{j t}, A R_{j t+1}\right)\right\}^{1 / 2}
$$


Please note that in the above equation, the covariance term has been introduced to eliminate the first order autocorrelation effect in the test statistics (as proposed by Heinkel and Kraus, 1988).

And,

$\bar{R}_{m}=$ average return on the market portfolio computed over the same event period used to estimate the market model for security " $\mathrm{j}$ ".

$\mathrm{T}=$ total number of days or months in the interval used to estimate the market model, and $\mathrm{N}=$ number of securities in the portfolio of interest.

The test statistic of the null hypothesis that the cumulative average residual (CAR) is equal to " 0 " is computed as:

$$
Z=\overline{C A R} / S(\overline{A R})
$$

Where,

$$
\text { Average adjusted } C A R=\overline{C A R}=\frac{1}{N}\left(\sum_{j=1}^{N} \overline{C A R}_{j}\right)
$$

$$
\text { Adjusted } C A R_{j}=\overline{C A R_{j}}=\left(\sum_{t=K}^{L} \overline{A R}_{j t}\right) /(Q)^{1 / 2}
$$


And, $\mathrm{K}$ and $\mathrm{L}$ represent the boundary points, in trading days, for some interval relative to a specific event day " 0 ".

$\mathrm{Q}$ is the number of trading days encompassed by the interval $\mathrm{K}, \mathrm{L}(\mathrm{Q}=\mathrm{L}-\mathrm{K}+1)$.

The Z-statistics presented above is approximately the unit normal for a large N. 


\section{APPENDIX G: METHODOLOGICAL ISSUES IN ESTIMATING LONG-TERM PERFORMANCE}

In estimating long-run performance, generally, two broad approaches can be identified in the literature: (a) the Event Time Approach and (b) the Calendar-time Approach. In the case of the event time approach, time is defined relative to the event. The calendar time approach takes into account the real date of the event.

\section{G.1 Event Time Approach}

In the event time approach, different measures are used to identify long-term performance. These can be categorized as (a) Cumulative Average Abnormal Return, and (ii) Buy-and-Hold abnormal return.

\section{G.1.1 Cumulative Abnormal Return (CAR)}

The convention in much of the earlier research that analyzes abnormal returns has been to sum either daily or monthly abnormal returns over time (Barber \& Lyon, 1997). Abnormal return for the sample is defined as:

$$
A R_{i t}=R_{i t}-E\left(R_{i t}\right)
$$


Where, $R_{i t}$ is the month " $t$ " simple return on a sample firm, and $E_{i t}$ is the month " $t$ " expected return for the sample firm. Subsequently, average abnormal returns for $\mathrm{N}$ firms and cumulative abnormal return over " $\tau$ " periods are calculated as:

$$
\begin{aligned}
& \overline{A R_{t}}=\frac{\sum_{i=1}^{N} A R_{i t}}{N} \\
& \overline{C A R \tau}=\sum_{t=1}^{\tau} \overline{A R_{t}}
\end{aligned}
$$

To test the null hypothesis that the mean cumulative abnormal returns are equal to " 0 " for a sample of " $N$ ", the common parametric test statistics used is:

$$
t_{C A R}=\overline{C A R_{i \tau}} /\left(\sigma\left(C A R_{i \tau}\right) / \sqrt{N}\right)
$$

Where $\sigma\left(C A R_{i \tau}\right)$ is the cross-sectional sample standard deviation of abnormal returns for the sample of $\mathrm{N}$ firms.

If the sample is drawn randomly from a normal distribution, these test statistics follow a Student's t-distribution under the null hypothesis. While the CARs are clearly nonnormal, the Central Limit Theorem guarantees that if the measures of abnormal returns in the cross-section of firms are independent and identically distributed drawings of finite variance distributions, the distribution of the mean abnormal return measure converges to normality as the number of firms in the sample increases (Barber \& Lyon, 1997). However, it has been reported that most of the mergers and acquisitions activities occur 
in an industry in the form of a cluster (Andrade \& Stafford, 1999) and hence, it casts serious doubt on the assumption of "independence" among the individual events. Most studies do not pay attention to this issue and report their results without making any adjustments for the plausible "dependence" among various events.

Expected return $E\left(R_{i t}\right)$ in Equation (G.1) is calculated in various ways, such as by using: (i) the market-adjusted model where market return or a reference portfolio is used as a proxy of expected return, (ii) the market model, (iii) the Capital Asset Pricing Model (CAPM), and (iv) the Fama-French three factor (FF 3-factor) model (Kohari \& Warner, 1997).

\section{Market-Adjusted Model}

$$
A R_{i t}=R_{i t}-R_{m t}
$$

Where $R_{i t}$ is the monthly return for security "I" in month " $t$ " and $R_{m t}$ is the monthly return on the market index.

Issues. This model is intuitive and relatively easy to use. However, as Barber and Lyon (1997) have pointed out, it suffers from three types of biases. First, the new listing bias arises because in event studies of long-run abnormal returns, sampled firms generally have a long post-event history of returns, while firms that constitute the index (or reference portfolio) typically include new firms that begin trading subsequent to the event month. Second, the rebalancing bias arises because the compound returns of a reference portfolio, such as an equally weighted market index, are typically calculated assuming 
periodic (generally monthly) rebalancing, while the returns of sample firms are compounded without rebalancing. Third, the skewness bias arises because long-run abnormal returns are positively skewed. Moreover, this model does not consider the "size" and the "book value to market value" factors while determining the abnormal returns.

\section{Market Model}

$$
A R_{i t}=R_{i t}-\alpha_{i}-\beta_{i} R_{m t}
$$

Where $\alpha_{i}$ and $\beta$ are market model parameter estimates obtained by regressing monthly returns for security "I" on the equally-weighted market returns over the estimation period.

Issues. Since this model uses the market index return, this would also suffer from new listing bias and rebalancing bias as discussed above. Another issue is that this model uses the pre-bid period for the identification of $\alpha_{i}$ and $\beta_{i}$ parameters, whereas the characteristics of bidders' security returns may change as a result of the bid. Post outcome returns would reflect these changes and bias the results (Limmack, 1991).

\section{CAPM}

$$
A R_{i t}=R_{i t}-R_{f t}-\beta_{i}\left(R_{m t}-R_{f t}\right)
$$


Where $\beta$ is from the CAPM regression model (i.e. slope from a regression of $\left[R_{i t}-R_{f t}\right]$ on $\left[R_{m t}-R_{f t}\right]$ for the estimation period and $R_{f t}$ is the one-month T-bill return used as a proxy for the risk-free return.

Issues. Concerns mentioned for the market model are again applicable for CAPM. Moreover, this model assumes the stationarity of the risk-free rate (Loderer \& Martin, 1992). The risk free rate could be driven up if the acquisition intensity increases in a period of time and alternately, it could decline if the acquisition activity subsidies. In addition, when we use CAPM, we are trapped by the "joint hypothesis" problem, i.e., we assume that the CAPM truly represents the expected return of the security. Also, CAPM does not consider the "size" and "book to market value" factors.

\section{FF 3-factor Model}

$$
A R_{i t}=R_{i t}-R_{f t}-\beta_{i 1}\left(R_{m t}-R_{f t}\right)-\beta_{i 2} H M L_{t}-\beta_{i 3} S M B_{t}
$$

Where $\beta_{i 1}, \beta_{i 2}$, and $\beta_{i 3}$ are estimated by regressing security "i's" monthly excess returns on the monthly market excess returns, book-to-market, and size factor returns for the estimation period. $H M L_{t}$ and $S M B_{t}$ are the Fama-French book-to-market and size factor returns. $H M L_{t}$ is the high-minus-low book-to-market portfolio return in month " $\mathrm{t}$ " and $S M B_{t}$ is the small-minus-big size portfolio return in month " $\mathrm{t}$ ".

Issues. The three-factor model considers the size and book-to-market value factors while determining the abnormal returns. However, as Barber and Lyon (1997) have 
documented, it has two disadvantages. First, given four parameters in the regression, it requires at least five observations of monthly returns post-event. This creates a survivor bias among remaining sample firms. Second, when long-horizon returns are considered, the regression estimates are assumed stable over the estimation period.

Barring all the individual problems tied to specific methods of determining abnormal returns, the common problem with event-time-based CAR is that it does not consider the compounding effect while calculating abnormal return. This is against the spirit of investors' experiences and would induce measurement bias (Barber \& Lyon, 1997).

\section{G.1.2 Buy-and-Hold Abnormal Return (BHAR)}

This approach has become increasing popular since the end of the 1990s. In contrast to the CAR method, the buy-and-hold abnormal return (BHAR) has been defined as the return on buy-and-hold investment in the sample firm less the return on a buy-and-hold investment in an asset/portfolio with an appropriate expected return, or:

$$
B H A R_{i \tau}=\prod_{t=1}^{\tau}\left[1+R_{i t}\right]-\prod_{t=1}^{\tau}\left[1+E\left(R_{i t}\right)\right]
$$

To test the null hypothesis that the mean cumulative abnormal returns are equal to " 0 " for a sample of "N", the common parametric test statistics used is:

$$
t_{B H A R}=\overline{B H A R_{i \tau}} /\left(\sigma\left(B H A R_{i \tau}\right) / \sqrt{N}\right)
$$


Where $\overline{B H A R_{i \tau}}$ is the sample average and $\sigma\left(B H A R_{i \tau}\right)$ is the cross-sectional sample standard deviations of abnormal returns for the sample of ' $N$ ' firms ${ }^{74}$.

Arguments for the normality assumption and Student's t-distribution are same as for CAR stated above. This test statistic of BHAR suffers from an "independence" assumption that could have serious implications for long-term abnormal performance detection (Mitchell \& Stafford, 2000). Like CAR, the expected return $E\left(R_{i t}\right)$ in Equation 2.9 is calculated in two ways: by using (i) a Reference portfolio return, and (ii) control firm return.

\section{Reference Portfolio Approach}

Under this approach, all the firms listed in a stock exchange are categorized into a number of groups (generally 25 to 50) based on each firm's respective "size" and "bookto-market value information". Each of these groups serves as a reference portfolio and BHAR is calculated by taking the difference between the buy-and-hold return of a sample firm and the buy-and-hold return of the closest reference portfolio in terms of "size" and "book-to-market value" information.

As reported by Barber and Lyon (1997), BHAR with a reference portfolio is subject to a new listing bias, a skewness bias, and a rebalancing bias. Subsequently, Lyon, Barber, and Tsai (1999) have presented the following skewness adjusted " $t$ " statistics to test the null hypothesis of abnormal return:

\footnotetext{
${ }^{74}$ In the case of a value-weighted BHAR, we use a market-value-weighted average BHAR and corresponding standard deviation in the $t$-statistics.
} 


$$
t_{s a}=\sqrt{N}\left(S+\frac{1}{3} \gamma S^{2}+\frac{1}{6 N} \widehat{\gamma}\right)
$$

Where,

$$
S=\frac{\overline{B H A R_{\tau}}}{\sigma\left(B H A R_{\tau}\right)}, \quad \text { and } \quad \hat{\gamma}=\frac{\sum_{i=1}^{N}\left(B H A R_{i \tau}-\overline{B H A R \tau}\right)^{3}}{N \sigma\left(B H A R_{\tau}\right)^{3}}
$$

Additionally, Mitchell and Stafford (2000) have presented the methodology for the adjustment of cross-sectional dependence of BHARs as follows:

$$
\frac{\sigma_{B H A R}(\text { independence })}{\sigma_{B H A R}(\text { dependence })} \approx \frac{1}{\sqrt{1+(N-1) \overline{\rho_{i, j}}}}
$$

Where, $\mathrm{N}=$ number of sample events, and $\overline{\rho_{i, j}}=$ average correlation of individual BHARs $^{75}$.

\footnotetext{
${ }^{75}$ For a detailed procedure, please refer to Mitchell and Stafford (2000).
} 


\section{Control Firm Approach}

As an alternative to the use of reference portfolios for the calculation of abnormal returns, a control firm return can be used in the BHAR calculation. In this approach, sample firms are matched to a control firm on the basis of specified firm characteristics, generally, size and book-to-market value.

The control firm approach eliminates the new listing bias (since both the sample and control firm must be listed in the identified event month), the rebalancing bias (since both the sample and control firm returns are calculated without rebalancing), and the skewness problem (since the sample and the control firms are equally likely to experience large positive returns). Finally, the cross-sectional dependence problem in the test statistics can be alleviated by the methodology provided by Mitchell and Staford (2000), as stated above.

\section{G.2 Calendar Time Approach}

An alternative approach to measuring long-term stock price performance is to track the performance of an event portfolio in calendar time relative to either an explicit assetpricing model or some other benchmark. The concept of the calendar time approach is not new (Jaffe, 1974; Mandelker, 1974) and is strongly advocated by some recent influential articles (Fama, 1998; Mitchell \& Stafford, 2000). In this approach, an event portfolio is formed in each period to include all companies that have completed the event within the prior " $\mathrm{n}$ " periods (generally 3 or 5 years). Under such rebalancing, new firms 
are added to the portfolio that has just executed a transaction and some other firms are dropped that reach the end of the pre-determined observation period (" $n$ " period). By forming event portfolios, the cross-sectional correlations of the event firm returns are automatically accounted for in the portfolio variance at each point in calendar time.

Abnormal returns in the calendar time approach are calculated using one of the two methods: by using (i) a reference portfolio return, or (ii) the Fama-French three-factor model.

\section{Reference Portfolio Approach}

Under this approach, the calendar time portfolio return is expressed as:

$$
C T A R_{t}=R_{p, t}-E\left(R_{p, \ell}\right)
$$

Where, $R_{p, t}$ is the calendar month portfolio return considering all the firms that have participated in the event within the previous prescribed period, and where $E\left(R_{p, t}\right)$ is the expected return on the event portfolio. Different forms of reference portfolios are used as a proxy for the expected return, such as (i) equally weighted and value weighted market index returns, and (ii) size and book to market value based portfolios ${ }^{76}$ (Gompers \& Lerner, 2003).

Issues. The calendar-time portfolio method offers some advantages over tests that employ either cumulative or buy-and-hold abnormal returns. First, this approach

\footnotetext{
${ }^{76}$ For a detailed procedure of the CTAR calculation using size-BV/MV portfolios see Lyon, Barber and Tsai (1999) - pp. 194-197.
} 
eliminates the problem of cross-sectional dependence among sample firms because the returns on sample firms are aggregated into a single portfolio. Second, the calendar-time portfolio methods yield more robust test statistics in nonrandom samples. However, in nonrandom samples, the calendar-time methods often yield mis-specified test statistics (Lyon, Barber, \& Tsai, 1999). Also, this approach gives equal weight on each month irrespective of the intensity of event activities in those months.

\section{Fama-French Three Factor Approach}

The Fama and French (1993) three-factor model is a parsimonious model for stock returns taking the form:

$$
R_{p, t}-R_{f, t}=a_{p}+b_{p}\left(R_{m, t}-R_{f, t}\right)+s_{p} S M B_{t}+h_{p} H M L_{t}
$$

where $\left(R_{m, t}-R_{f, t}\right)$ is the market factor, constructed by subtracting the T-bill return from the market return. SMB is the size factor, constructed by taking the return on a portfolio of small stocks minus the return on a portfolio of big stocks. HML is the book-to-market factor, formed by taking the return on a portfolio of value stocks (with high book-tomarket ratios) and subtracting the return on a portfolio of growth stocks (with low bookto-market ratios). $R_{p, t}$ is the calendar month portfolio return considering all the firms that have participated in the event within the previous prescribed period. In the Fama-French three-factor model, " $\mathrm{a}_{\mathrm{p}}$ " denotes the calendar time abnormal return.

Issues. Like the reference portfolio approach stated above, there are similar advantages for the Fama-French Three Factor approach. However, there are also some potential 
problems with this approach. First, the regression assumes that the factor loadings are constant through time, which is unlikely since the composition of the event portfolio changes each month. These events tend to cluster through time by industry, and different industries have different factor loadings (Fama \& French, 1997; Mitchell \& Stafford, 2000). Second, this approach weights each month equally ${ }^{77}$, so that months that reflect heavy event activity are treated same as months with low activity (Loughran \& Ritter, 2000). Third, there is the issue of the "joint-hypothesis" problem as the Fama-French Three Factor model might not truly represent or reflect the "normal" return (Loughran \& Ritter, 2000). Fourth, the measurement of the factor coefficients in the model will be biased unless event firms are excluded from the reference portfolios ${ }^{78}$ (Loughran \& Ritter, 2000; Vijh, 1994). Fifth, this portfolio approach in calendar time introduces heteroscedasticity ${ }^{79}$, since the number of firms in the sample varies over time (Franks et. al., 1991; Mitchell \& Stafford, 2000). Finally, Loughran and Ritter (2000) show that the Fama-French three-factor model exhibits low power in detecting abnormal return, especially when value-weighted abnormal returns are used. However, Mitchell and Stafford (2000) disagree with such findings.

\footnotetext{
${ }^{77}$ A number of studies have recommended using weighted least square technique (using square root of the number of firms included in each monthly portfolio) to mitigate this problem (Andre et al. 2004)

${ }_{78}$ This is termed as 'Benchmark Contamination' by Loughran and Ritter (2000).

${ }^{79}$ Franks et al. (1991), and Mitchell and Stafford (2000) propose a correction for such heteroscedasticity.
} 


\section{APPENDIX H: METHODOLOGICAL ISSUES IN DETECTING THE DIFFERENTIATING CHARACTERISTICS OF A BIDDING FIRM}

Most of the studies in this area use Logit Analysis in order to determine the factors related to the event of a merger or acquisition (Brook et. al., 2000; Loderer and Martin, 1990; Palepu, 1986). Logit analysis employs a logistic cumulative probability curve, which closely approximates a normal curve except that it is fatter at the tails of the distribution (Dietrich \& Sorensen, 1984). The cumulative probability "P" of an event "E" is expressed as:

$$
P(Y)=\left(1+e^{-Y}\right)^{-1}
$$

Where, $\mathrm{Y}$ is a linear function of the observable independent variables, $\mathrm{X}_{\mathrm{i}}$ 's, and the parameters $\alpha$ and $\beta_{i}$. $X_{i}$ 's are generally firm attributes and $\alpha$ and $\beta$ are the parameters to be estimated,

$$
Y=\alpha+\sum \beta_{i} X_{i}
$$

As an alternative approach, some studies have also used Multivariate Discriminant Analysis (MDA) in the past. However, as Dietrich and Sorensen (1984) and Eisenbeis (1977) point out, Logit analysis would be a preferred methodology for the following reasons: (a) the use of logit analysis does not depend on the assumption that independent variables are distributed multivariate normal as is required by MDA; (b) logit analysis enables direct interpretation of the various explanatory variable coefficient estimates. 
MDA coefficients estimates are only unique up to a factor of proportionality, rendering interpretation of their relative significance difficult.

\section{Model Fit Issue in Logistic Regression}

As Agresti (1996) has mentioned, in the presence of continuous data, it will not be appropriate to determine the Goodness-of-Fit for a model by using the more conventional Pearson Chi-square or $\mathrm{G}^{2}$ statistics. These tests are more appropriate when the explanatory variables are "Categorical". The large sample theory for Pearson Chi-square and $G^{2}$ applies for a fixed number of cells when the fitted counts are large. This theory will be violated here in two ways. First, most fitted values will be extremely small. Second, when more data are collected, more additional values for continuous variables (like firm size, market-to-book value) would occur so the contingency table would contain more cells rather than a fixed number. Because of this, Pearson Chi-square and $\mathrm{G}^{2}$ for logistic regression models fitted with continuous or nearly continuous predictors will not have approximate Chi-squared distributions.

However, as Agresti (1996) states, "when explanatory variables are continuous, it is difficult to analyze lack of fit without some type of grouping. As the number of explanatory variables increases, however, simultaneous grouping of values for each variable can provide a contingency table with a large number of cells, many of which have small counts. An alternative way of grouping forms observed and fitted values based on a partitioning of predicted probabilities" (p. 113). 
Therefore, Agresti suggests following the Hosmer-Lemeshow (HL) test statistics to find out the goodness of fit for a model. The HL procedure is based on the forming of groups according to predicted probabilities. Their Pearson-like statistics are roughly approximated by the Chi-squared with the degrees of freedom given by the number of groups minus 2. We obtain the HL test statistics from a standard statistical package output like SPSS.

\section{Predicting the Capability of the Models}

In addition to determining the characteristics of a target firm, a number of empirical studies have attempted to predict acquisition targets (Dietrich \& Sorenson, 1984; Loderer \& Martin, 1990) and acquirers (Harford, 1999). The results reported by these authors indicate that such models have impressive abilities to predict acquisition targets 6 to 12 months before the announcement of takeovers. In contrast to the predictive ability claimed by the above studies, however, the stock market does not seem to predict acquisition targets with a high degree of accuracy even three months prior to the announcement of takeover bids (Palepu, 1986). Moreover, Thomas (1997) has documented that takeover likelihood models are not robust over time. Also, Ambrose and Megginson (1992) re-estimate, on a different time period, the models estimated in Papelu's work (1986). They find that the characteristics found to be significant by Papelu (1986) are not significant in a subsequent time period. Therefore, we need to interpret the predicting capabilities of the models more carefully. 
The earlier target prediction models generally used non-random equal share samples in their model estimations and specified arbitrary cutoff probabilities in the prediction tests. As Papelu (1986) states, such an approach leads to three principal methodological flaws, which make the reported accuracies of the prediction models unreliable. "First, the use of non-random, equal share samples in the model estimation, without appropriate modification to the estimators, leads to inconsistent and biased estimates of the model parameters and the acquisition probabilities. This results in overstating the model's ability to predict targets. Second, the use of equal share samples in prediction tests leads to error rate estimates that fail to represent the model's predictive ability in the population. Third, the use of arbitrary cutoff probabilities (usually 0.5 ) in the prediction tests without specifying a decision context, the relevant state-payoff matrix, and the prior state probabilities, makes the reported prediction accuracies difficult to interpret" (p. 31).

Subsequently, Papelu (1986) proposes corrective measures and proposes to run the predictive models with proper specifications. As expected, the predictive power of the model declines and it appears that it is difficult to predict targets. Given these justifications, along with the temporal unreliability of the determinants (Thomas, 1997), we may conclude that it would be wise not to use likelihood models as predictive ones. Rather, it would be prudent to confine the use of the logit model to determining the differing characteristics/factors of two different groups of firms (for example target and non-target firms; acquirer and non-acquirers). 


\section{APPENDIX I: PRELIMINARY DOCUMENTATION OF CANADIAN M\&A ACTIVITY $^{80}$}

Like the U.S. market, the Canadian M\&A market has also experienced rises and declines over the last fifteen years. The dollar value of M\&A announcements gradually decreased from $\$ 30$ billion CDN in 1989 to $\$ 17$ billion CDN in 1992 . Thereafter, fueled by robust economic growth and favorable economic conditions, the Canadian M\&A market increased from $\$ 35$ billion CDN in 1993 in announcement value to $\$ 234$ billion CDN in 2000 (see Table I.1). Towards the end of the 1990s, the economy was positive about technological developments and numerous acquisitions took place in high-tech sectors, led by Nortel and JDS. At the same time, market confidence was high, partly due to the buoyant economy in the U.S. along with a relatively strong job market. In the second half of 2000 , the Canadian M\&A market started to decline because of slower economic growth in Canada and the U.S. This was again compounded by the "Internet Bubble" burst in 2000-2001 that left many technology stocks reeling. In 2001, the number of mega-deals - worth $\$ 1$ billion CDN or more - decreased to 21 totaling $\$ 68$ billion CDN in 2001 versus a high-water mark of 37 mega-deals worth \$144 billion CDN in 2000.

The Canadian M\&A market again started to pick up in the second half of 2003. The total value of announced transactions in the second half of 2003 was $\$ 55$ billion CDN, nearly double the $\$ 28$ billion CDN in the first half on a comparable number of deals. The increasing trend in M\&A activities continued in the first two quarters of 2004. A combination of higher continued cross-border activity, increasing average deal size,

\footnotetext{
${ }^{80}$ Source: Crosbie and Co.'s Annual M\&A Directories.
} 
significant activities in the oil and gas sector, and solid income trust and REIT related activities contributed to the favorable M\&A environment during 2004-2005.

Table I.1 M\&A Deals and Associated Values

\begin{tabular}{ccc}
\hline Year & Number of Deals & \$Billion CDN \\
\hline 1989 & 1208 & 30 \\
1990 & 828 & 20 \\
1991 & 723 & 18 \\
1992 & 551 & 17 \\
1993 & 895 & 35 \\
1994 & 1066 & 47 \\
1995 & 968 & 78 \\
1996 & 1185 & 75 \\
1997 & 1264 & 102 \\
1998 & 1163 & 148 \\
1999 & 1230 & 178 \\
2000 & 1297 & 234 \\
2001 & 914 & 128 \\
2002 & 852 & 92 \\
2003 & 833 & 83 \\
\hline
\end{tabular}


Table I.2 M\&A Activity Grouped by Industry (1994-2002)

\begin{tabular}{|c|c|c|c|c|c|c|c|c|c|c|c|c|c|c|c|c|c|c|}
\hline \multirow[t]{2}{*}{ Group } & \multicolumn{2}{|c|}{2002} & \multicolumn{2}{|c|}{2001} & \multicolumn{2}{|c|}{2000} & \multicolumn{2}{|c|}{1999} & \multicolumn{2}{|c|}{1998} & \multicolumn{2}{|c|}{1997} & \multicolumn{2}{|c|}{1996} & \multicolumn{2}{|c|}{1995} & \multicolumn{2}{|c|}{1994} \\
\hline & $\mathbf{N}$ & $\$ \mathrm{Mil}$ & $\bar{N}$ & \$ Mil & $\mathbf{N}$ & \$Mil & $\mathrm{N}$ & \$ Mil & $\mathrm{N}$ & \$ Mil & $\mathrm{N}$ & \$ Mil & $\mathrm{N}$ & \$ Mil & $\mathrm{N}$ & \$ Mil & $\mathrm{N}$ & \$ Mil \\
\hline $\begin{array}{l}\text { Industrial } \\
\text { Products }\end{array}$ & 208 & 7051 & 255 & 21420 & 464 & 70626 & 395 & 55082 & 303 & 25939 & 242 & 7279 & 266 & 10133 & 201 & 10139 & 230 & 5746 \\
\hline Oil \& Gas & 102 & 20584 & 117 & 28060 & 149 & 21174 & 131 & 10363 & 115 & 12559 & 166 & 14755 & 149 & 10171 & 116 & 22685 & 106 & 5443 \\
\hline $\begin{array}{l}\text { Consumer } \\
\text { Products }\end{array}$ & 90 & 6269 & 95 & 2752 & 141 & 52228 & 136 & 5286 & 130 & 24973 & 124 & 9708 & 120 & 8595 & 114 & 7864 & 127 & 2470 \\
\hline $\begin{array}{l}\text { Financial } \\
\text { Services }\end{array}$ & 79 & 13983 & 113 & 26446 & 136 & 14465 & 122 & 26996 & 125 & 8585 & 136 & 14700 & 112 & 7131 & 91 & 3738 & 102 & 5878 \\
\hline $\begin{array}{l}\text { Commun, \& } \\
\text { Media }\end{array}$ & 51 & 5427 & 81 & 5091 & 115 & 26868 & 88 & 7714 & 110 & 9785 & 110 & 16197 & 114 & 9745 & 109 & 14519 & 116 & 9837 \\
\hline Merchandising & 54 & 1823 & 51 & 4848 & 79 & 2944 & 97 & 6251 & 106 & 7600 & 111 & 4305 & 125 & 3426 & 73 & 2785 & 117 & 2344 \\
\hline Real Estate & 90 & 6988 & 38 & 4694 & 50 & 5337 & 48 & 6732 & 94 & 11507 & 172 & 9591 & 88 & 6580 & 62 & 4318 & 40 & 2313 \\
\hline Utilities & 54 & 16740 & 50 & 12551 & 43 & 17932 & 54 & 16981 & 34 & 25590 & 22 & 1932 & 23 & 1830 & 17 & 464 & 23 & 1207 \\
\hline $\begin{array}{l}\text { Trans. \& Env. } \\
\text { Service }\end{array}$ & 34 & 1408 & 31 & 2073 & 42 & 990 & 50 & 29738 & 56 & 7877 & 57 & 8668 & 44 & 2963 & 30 & 2616 & 46 & 1603 \\
\hline $\begin{array}{l}\text { Metals \& } \\
\text { Minerals }\end{array}$ & 25 & 2701 & 28 & 1549 & 33 & 3490 & 29 & 2553 & 30 & 2961 & 39 & 2313 & 47 & 6544 & 46 & 3836 & 49 & 3106 \\
\hline $\begin{array}{l}\text { Paper \& } \\
\text { Forest } \\
\text { Products }\end{array}$ & 20 & 2117 & 27 & 5933 & 19 & 8478 & 37 & 7851 & 24 & 5998 & 31 & 9725 & 24 & 3176 & 41 & 3986 & 40 & 2635 \\
\hline Gold \& Silver & 38 & 4587 & 23 & 10755 & 18 & 339 & 42 & 2427 & 35 & 4765 & 51 & 1084 & 71 & 4927 & 67 & 1557 & 68 & 3857 \\
\hline Pipelines & 7 & 2697 & 5 & 1374 & 8 & 1491 & 1 & 0 & 1 & 33 & 3 & 1355 & 2 & 109 & 1 & 50 & 2 & 48 \\
\hline TOTAL & 852 & 92375 & 914 & 127546 & 1297 & 226362 & 1230 & 177974 & 1163 & 148172 & 1264 & 101612 & 1185 & 75330 & 968 & 78557 & 1066 & 46487 \\
\hline
\end{tabular}

Source: Crosbie Annual Reports 
Table I.3 Forms of Transaction Payments (1993-2002)

\begin{tabular}{|c|c|c|c|c|c|c|c|c|c|c|}
\hline Year & 2002 & 2001 & 2000 & 1999 & 1998 & 1997 & 1996 & 1995 & 1994 & 1993 \\
\hline All Cash & $56 \%$ & $48 \%$ & $41 \%$ & $46 \%$ & $50 \%$ & $46 \%$ & $60 \%$ & $67 \%$ & $61 \%$ & $65 \%$ \\
\hline All Stock & $13 \%$ & $25 \%$ & $27 \%$ & $24 \%$ & $17 \%$ & $16 \%$ & $16 \%$ & $18 \%$ & $18 \%$ & $19 \%$ \\
\hline Combination & $31 \%$ & $27 \%$ & $32 \%$ & $30 \%$ & $33 \%$ & $38 \%$ & $24 \%$ & $15 \%$ & $21 \%$ & $16 \%$ \\
\hline
\end{tabular}

Source: Crosbie Annual Reports

Note that M\&A activities vary quite significantly across industries. Traditionally, sectors like industrial products, oil and gas, consumer products and financial services dominate the Canadian M\&A market (Table I.2). We can also see a sizable preference for cash transactions over the years in M\&A deals (Table I.3). However, the gap has reduced to some extent towards the end of the 1990 s as we can see increased preference for stock payments. This could be due to the buoyant stock market in that period which makes the management of bidding firms believe that their stocks are overvalued. Since 2001 (after the bust of technology stocks), stock payments declined again. Moreover, if the management perceives that the risk associated with M\&A activities in that time period is high, they would prefer to make stock payments. 


\section{APPENDIX J: CROSS-CORRELATION CALCULATION}

We followed the Mitchell and Stafford (2000) methodology to calculate average crosscorrelation, which in turn was used to calculate corrected " $t$ " statistics in the buy-andhold abnormal return (BHAR) analysis. The steps were as follows:

First, we assumed a simple correlation structure to calculate the average correlation of 3 year BHARs across all of our 1300 observations ${ }^{81}$. We assumed that the correlation was decreasing linearly as the number of overlapping months was decreasing from 36 (see Table J.1). Second, we identified all acquisition events that had a 36-month overlap from the effective date (i.e. complete overlap). We calculated the average correlation for such cases. The average correlation for the 36-month overlapping cases is 0.130344 (Table J.1). Third, we estimated the correlation of other overlapping months by using the 36month average correlation. For example, with 35 months of overlap, the average correlation is $(35 / 36)^{*} 0.130344=0.126723$ (Table J.1). Third, we calculated the weighted average correlation, which is 0.040405 . Finally, we used the following equation to calculate the ratio of standard deviation assuming independence to standard deviation considering dependence.

$$
\frac{\sigma_{B H A R}(\text { independence })}{\sigma_{B H A R}(\text { dependence })} \approx \frac{1}{\sqrt{1+(N-1) \overline{\rho_{i, j}}}}
$$

\footnotetext{
${ }^{81}$ Within these 1300 events, we used the cases that had no missing monthly return data in the 36-month period starting from the effective date of a completed deal.
} 
Where, $\mathrm{N}=$ number of sample events, and $\overline{\rho_{i, j}}=$ average correlation of individual BHARs (0.040405).

Table J.1 Correlation Structure for all Acquiring Firms

\begin{tabular}{|c|c|c|c|}
\hline $\begin{array}{c}\text { Number of months } \\
\text { of overlap }\end{array}$ & $\begin{array}{c}\text { Number of unique } \\
\text { correlation }\end{array}$ & $\begin{array}{c}\text { Assumed Correlation } \\
\text { Structure } \\
\end{array}$ & $\begin{array}{c}\text { Estimated } \\
\text { Correlation } \\
\end{array}$ \\
\hline 36 & 6121 & $\rho$ & 0.130344 \\
\hline 35 & 8427 & $35 / 36 . \rho$ & 0.126723 \\
\hline 34 & 8471 & $34 / 36 . \rho$ & 0.123102 \\
\hline 33 & 8467 & $33 / 36 \cdot p$ & 0.119482 \\
\hline 32 & 8573 & $32 / 36 . \rho$ & 0.115861 \\
\hline 31 & 8536 & $31 / 36 . \rho$ & 0.11224 \\
\hline 30 & 8848 & $30 / 36 . \rho$ & 0.10862 \\
\hline 29 & 8348 & $29 / 36 . \rho$ & 0.104999 \\
\hline 28 & 8240 & $28 / 36 \cdot \rho$ & 0.101378 \\
\hline 27 & 7870 & $27 / 36 . \rho$ & 0.097758 \\
\hline 26 & 7856 & $26 / 36 . \rho$ & 0.094137 \\
\hline 25 & 7553 & $25 / 36 \cdot \rho$ & 0.090516 \\
\hline 24 & 10471 & $24 / 36 . \rho$ & 0.086896 \\
\hline 23 & 7538 & $23 / 36 . \rho$ & 0.083275 \\
\hline 22 & 7572 & $22 / 36 \cdot \rho$ & 0.079654 \\
\hline 21 & 7561 & $21 / 36 \cdot \rho$ & 0.076034 \\
\hline 20 & 7864 & $20 / 36 \cdot \rho$ & 0.072413 \\
\hline 19 & 7678 & $19 / 36 . \rho$ & 0.068792 \\
\hline 18 & 7936 & $18 / 36 . \rho$ & 0.065172 \\
\hline 17 & 7720 & $17 / 36 \cdot \rho$ & 0.061551 \\
\hline 16 & 7495 & $16 / 36 \cdot \rho$ & 0.057931 \\
\hline 15 & 6863 & $15 / 36 . \rho$ & 0.05431 \\
\hline 14 & 6802 & $14 / 36 . \rho$ & 0.050689 \\
\hline 13 & 6719 & $13 / 36 \cdot \rho$ & 0.047069 \\
\hline 12 & 9103 & $12 / 36 \cdot \rho$ & 0.043448 \\
\hline 11 & 6498 & $11 / 36 . \rho$ & 0.039827 \\
\hline 10 & 6556 & $10 / 36 . \rho$ & 0.036207 \\
\hline 9 & 6706 & $9 / 36 . \rho$ & 0.032586 \\
\hline 8 & 6675 & $8 / 36 . \rho$ & 0.028965 \\
\hline 7 & 6485 & $7 / 36 . \rho$ & 0.025345 \\
\hline 6 & 6819 & $6 / 36 \cdot \rho$ & 0.021724 \\
\hline 5 & 6552 & $5 / 36 \cdot \rho$ & 0.018103 \\
\hline 4 & 6362 & $4 / 36 \cdot \rho$ & 0.014483 \\
\hline 3 & 5940 & $3 / 36 \cdot \rho$ & 0.010862 \\
\hline 2 & 5953 & $2 / 36 . \rho$ & 0.007241 \\
\hline 1 & 5836 & $1 / 36 . \rho$ & 0.003621 \\
\hline 0 & 200389 & 0 & 0 \\
\hline Total & 469403 & Average correlation & 0.040405 \\
\hline
\end{tabular}

Note: 2002 data are excluded for this analysis, as we used only the 24-month post acquisition data for the 2002 events. 


\section{APPENDIX K: COMPARISON OF OVERLAPPING AND NON-OVERLAPPING ACQUIRING FIRMS' CHARACTERISTICS}

We investigated the differentiating characteristics of the non-overlapping and overlapping acquiring firms and the results are reported in Table K1. We found that nonoverlapping firms were smaller in size and had lower pre-event performances (return on equity and cash flow to total asset) compared to overlapping firms. Also, the option-pay to cash-pay ratio for the overlapping firms' CEOs is higher compared to that of the nonoverlapping firms' CEOs. These results are not surprising, as larger firms with better performances are likely to make more acquisitions. Further, higher option pay will allow CEOs to take more risk. However, our findings also indicate that there is no significant difference between these two groups with respect to long-term BHAR and long-term operating performance.

Table K.1 Comparison of overlapping and non-overlapping acquiring firms' characteristics "Market value" is the year-end market value of firm's equity as reported in Stock Guide database. "Total asset" is the sum of all fixed and current assets of the acquiring firm as appear in the balance sheet for the year prior to the year in which acquisition is made. "Price to book value" is the ratio of the firm's market value to book value in the prior year. "Cash flow to total asset" is the ratio of the firm's cash flow to total asset in the prior year. "Return on equity" is the ratio of net income to net worth of firm in the prior year. "Pay ratio" is the ratio of CEO's stock option value (CEO's aggregate realized option value in a year + CEO's unexercised option value) to cash pay. "CEO ownership" is the percentage of outstanding shares owned by the CEO. Subsequently, three categories are created for CEO ownership, namely, for less than $5 \%, 5-25 \%$, and more than $25 \%$. "Blockholder ownership" is the percentage of outstanding shares owned by individuals or institutions other than the directors. If the blockholder ownership is less than $10 \%$, the input value for this variable is zero. Subsequently three categories are created for blockholder ownership, namely, for less than $10 \%, 10-25 \%$, and more than $25 \%$. "Director ownership" is the percentage of outstanding shares owned by all directors (including the CEO) of the firm. Subsequently, three categories are created for director ownership, namely, for less than $5 \%, 5-25 \%$, and more than $25 \%$. "BHAR" is the buy and hold abnormal return based on the average difference in the aggregated (compounded) performance between the included stock and the benchmark over a 36-month period starting after the effective month of acquisition. BHAR6 uses individual matching firm return as the benchmark. The individual marching firm is selected based on the nearest propensity score with respect to firm size and price to book value. "Industry adjusted post and pre difference" is the average of the difference between "Industry adjusted post average cash flow to total asset" and "'Industry adjusted pre-average cash flow to total asset". "Matching firm adjusted post and pre difference" is the average of the difference between 
"Matching adjusted post average cash flow to total asset" and "Matching adjusted pre average cash flow to total asset".

\begin{tabular}{|c|c|c|c|c|}
\hline Characteristics & & $\begin{array}{l}\text { Mean Difference } \\
\text { (Overlapping - } \\
\text { Non-overlapping) }\end{array}$ & t-stat & Sig. \\
\hline Market Value (MMKTVAL1) & Equal variances assumed & $638457.29 * * *$ & 4.51 & 0.00 \\
\hline (in '000\$) & Equal variances not assumed & $638457.29 * * *$ & 5.25 & 0.00 \\
\hline Total Asset (TASST1) & Equal variances assumed & $917388.45^{* * *}$ & 3.99 & 0.00 \\
\hline (in '000\$) & Equal variances not assumed & $917388.45^{* * *}$ & 4.93 & 0.00 \\
\hline Price to book value (PRBV1) & Equal variances assumed & 0.24 & 1.37 & 0.17 \\
\hline (ratio) & Equal variances not assumed & 0.24 & 1.28 & 0.20 \\
\hline Cash flow to total asset & Equal variances assumed & $0.02 * *$ & 2.35 & 0.02 \\
\hline (CFTASST1) (ratio) & Equal variances not assumed & $0.02 * *$ & 2.19 & 0.03 \\
\hline Return on equity (REQUTY1) & Equal variances assumed & $3.41 * *$ & 1.98 & 0.05 \\
\hline$(\%)$ & Equal variances not assumed & $3.41 * *$ & 1.93 & 0.05 \\
\hline CEO ownership (CEOOWN) & Equal variances assumed & -3.11 & -1.55 & 0.12 \\
\hline$(\%)$ & Equal variances not assumed & -3.11 & -1.49 & 0.14 \\
\hline CEO pay ratio & Equal variances assumed & $2.76 * * *$ & 4.08 & 0.00 \\
\hline (PAYRAT1) (ratio) & Equal variances not assumed & $2.76 * * *$ & 4.94 & 0.00 \\
\hline Blockholder ownership & Equal variances assumed & -0.44 & -0.24 & 0.81 \\
\hline$(\mathrm{BLKOWN})(\%)$ & Equal variances not assumed & -0.44 & -0.24 & 0.81 \\
\hline Director ownership (DIROWN) & Equal variances assumed & $-4.66 * * *$ & -2.49 & 0.01 \\
\hline$(\%)$ & Equal variances not assumed & $-4.66 * *$ & -2.36 & 0.02 \\
\hline Matching firm buy and hold & Equal variances assumed & 0.11 & 1.21 & 0.23 \\
\hline $\begin{array}{l}\text { abnormal return (BHAR6) } \\
\text { (decimal) }\end{array}$ & Equal variances not assumed & 0.11 & 1.22 & 0.22 \\
\hline Industry adjusted (post - pre) & Equal variances assumed & 0.00 & -0.11 & 0.91 \\
\hline $\begin{array}{l}\text { operating performance } \\
\text { (IDIFFAVG) (decimal) }\end{array}$ & Equal variances not assumed & 0.00 & -0.10 & 0.92 \\
\hline Matching firm adjusted (post - & Equal variances assumed & 0.00 & -0.05 & 0.96 \\
\hline $\begin{array}{l}\text { pre) operating performance } \\
\text { (MDIFFAVG) (decimal) }\end{array}$ & Equal variances not assumed & 0.00 & -0.04 & 0.97 \\
\hline
\end{tabular}




\section{APPENDIX L: CEO HUBRIS}

We proxy for CEO hubris by the CEO excess pay that is determined by the governance characteristics of a firm ${ }^{82}$. As Core et al. (1999) have argued, CEO excess pay is the manifestation of a firm's weak governance. A number of other studies have posited that a firm with a weak governance system gives more power to the CEO, who in turn, can influence the other directors with respect to the compensation decision (Bebchuk \& Fried, 2003; Grinstein \& Hribar, 2004). These studies have shown that firms with less effective governance tend to pay greater CEO compensation. In other words, a weaker governance system in a firm gives more power to CEOs to extract more personal benefits. Consistent with this view, we use CEO excess pay as a proxy for CEO hubris that is derived from CEO power.

In order to determine CEO excess pay, we have followed the methodology proposed by Core et al. (1999). First, the predicted value of CEO pay has been determined with the help of the following cross-sectional multiple regression using 1997-2002 data:

CEO Pay $=F n$ (Economic determinants) $+F n$ (governance variables)

$=F n$ (Revenue, avg. price to book value, return on asset, 1-year stock return, standard deviation of return on asset, standard deviation of stock return) + Fn (Chairman is related, percentage of inside directors, board size, CEO ownership, directors' ownership, blockholder ownership).

\footnotetext{
${ }^{82}$ Hayward and Hambrick (1997) states, "there is no reliable instrument to measure CEO hubris directly" (p. 107). As an indirect measure, they recommend to use past firm performance and board characteristics along with media praise for the CEO.
} 
The regression equation includes two variations of CEO pay: (i) CEO cash pay; and (ii) CEO total pay. "CEO cash pay" is the sum of salary and annual cash bonus. "CEO total pay" is the sum of salary, cash bonus, and realized stock option pay in that year. The compensation data were obtained from the management information circular.

Subsequently, two versions of CEO excess pay (one for cash pay and one for total pay) are determined using the following equation:

$\begin{aligned} \text { CEO Excess Pay } & =\text { Coefficient } * \text { Governance variables } \\ & =\text { Coefficient }{ }^{*} \text { Board variables }+ \text { Coefficient }{ }^{*} \text { Ownership variables }\end{aligned}$

Variable descriptions and descriptive statistics of each variable are presented in Table L.1 and the results of OLS multiple regression are presented in Table L.2.

\section{Conjectures and Proxies}

Prior theories and empirical evidence suggest that larger firms with higher growth potentials and better performances will pay higher compensation (Carpenter \& Sanders, 2002; Cordeiro \& Viliyath, 2003; Core et al., 1999; Smith \& Watts, 1992). We use revenue as a proxy for firm size, five-year average price to book value as a proxy for growth and investment potential, and return on asset and stock return as proxy for past performance. We also control for firm risk (standard deviation of ROA and standard deviation of stock return) as suggested by a number of prior research studies (Core et al., 1999; Smith \& Watts, 1992). 
Earlier studies have argued that the presence of a substantial blockholder would negatively impact CEO pay (Cordeiro \& Viliyath, 2003; Mangel \& Singh, 1993; Werner and Tosi, 1995;). Core et al. (1999) and Conyon and Peck (1998) have shown that firms with a related board chairman and more inside directors tend to pay more to a CEO. We do not see any comprehensive economic theory relating the size of a corporate board with performance (Wu, 2000). However, Jensen (1993) and Lipton and Lorsch (1992) have suggested that large boards can be less effective than small boards. When boards become too big, agency problems (such as director free-riding) increase and the board becomes more symbolic and less a part of the management process (Hermalin \& Weisbach, 2003; Jensen, 1993). Consequently, it can be argued that firms with larger board sizes would pay more to a CEO.

The relationship between CEO ownership and compensation is not obvious. Higher levels of CEO ownership will give the CEO the power and leverage to extract more cash salary and bonus. However, CEOs holding a large fraction of their firms' equity are less likely to demand further stock-based compensation, for at least for two reasons: (i) the interests of CEOs and shareholders are already relatively aligned (Jensen \& Meckling, 1976); and (ii) since CEOs have already invested their human capital in the firm they would try to diversify risk by not taking a very high ownership stake in the same firm (Smith \& Watts, 1992; Yermack, 1995). Accordingly, it has been argued that when CEOs hold a large fraction of their firm's equity, their boards of directors decrease the intensity of incentives provided by stock-based awards and shift the mix of CEO pay toward cash compensation (Beatty \& Zajac, 1994; Bryan, 2000; Yermack, 1995). 


\section{Table L.1 Descriptive Statistics of CEO Compensation and its Determinants}

The sample consists of 838 annual observations for acquiring and non-acquiring firms between 1997 and 2002. For acquiring firms, only one event is considered in case of multiple acquisitions by the firm in any year. In the regression model, the number of cases are less than 838 due to list-wise deletion of the cases with missing data.

\section{Panel A. CEO pay}

"CEO cash pay" is the sum of salary and annual cash bonus. "CEO total pay" is the sum of salary, cash bonus, and realized stock option pay in that year. The compensation data were obtained from management information circulars.

\begin{tabular}{lrr}
\hline (in \$ CDN) & Cash pay & \multicolumn{1}{c}{ Total pay } \\
\hline Mean & 536976 & 765088 \\
Median & 364827 & 419375 \\
Std Dev & 514297 & 956015 \\
\hline
\end{tabular}

Panel B. Economic determinants

"Revenue" is for the year prior to the year in which compensation is awarded. "Average price to book value" is over five years prior to the year in which CEO compensation was awarded. "Return on asset" is the percentage return on total assets for the prior year. "1-year Stock Return" is calculated based on yearend stock prices of the prior year. "Std. dev. of return on asset" is the standard deviation of the firm's return on assets over five prior years. "Std. dev. of stock return" is the standard deviation of the 1-year stock return over four years prior to the year in which compensation was awarded.

\begin{tabular}{lcccccc}
\hline & $\begin{array}{c}\text { Revenue } \\
\text { (in '000\$) }\end{array}$ & $\begin{array}{c}\text { Avg. price to } \\
\text { book value } \\
\text { (ratio) }\end{array}$ & $\begin{array}{c}\text { Return on } \\
\text { asset (\%) }\end{array}$ & $\begin{array}{c}\text { 1-year stock } \\
\text { return } \\
\text { (decimal) }\end{array}$ & $\begin{array}{c}\text { Std. Dev. of } \\
\text { ROA (\%) }\end{array}$ & $\begin{array}{c}\text { Std. Dev. of } \\
\text { stock return } \\
\text { (decimal) }\end{array}$ \\
\hline Mean & 845257.5 & 3.1 & -2.3 & 0.4 & 11.3 & 0.7 \\
Median & 101996.0 & 2.1 & 3.1 & 0.1 & 5.3 & 0.4 \\
Std Dev & 2229615.6 & 3.8 & 17.3 & 1.4 & 15.0 & 1.0 \\
\hline
\end{tabular}

Panel C. Governance variables

"CEO is related" is a dummy variable equal to " 1 " if the chair is related to management or the board, " 0 " otherwise. For example, if the CEO is also the chair of the board, the dummy variable is equal to " 1 ". "Percentage of inside directors" is the ratio of related directors to total board size. "Board size" is the number of directors on the board. "CEO ownership" is the percentage of outstanding shares owned by CEO. "Blockholder ownership" is the percentage of outstanding shares owned by individuals or institutions other than the directors. If the blockholder ownership is less than $10 \%$, the input value for this variable is " 0 ". "Director ownership" is the percentage of outstanding shares owned by all directors together of the firm.

\begin{tabular}{lcccccc}
\hline & $\begin{array}{c}\text { Chair is } \\
\text { related }\end{array}$ & $\begin{array}{c}\text { \% of inside } \\
\text { directors }\end{array}$ & $\begin{array}{c}\text { Board } \\
\text { size }\end{array}$ & $\begin{array}{c}\text { CEO } \\
\text { ownership \% }\end{array}$ & $\begin{array}{c}\text { Blockholder } \\
\text { ownership \% }\end{array}$ & $\begin{array}{c}\text { Director } \\
\text { ownership \% }\end{array}$ \\
\hline Mean & 0.6 & 30 & 8.1 & 10.46 & 10.08 & 18.15 \\
Median & 1.0 & 30 & 7.0 & 1.79 & 0.00 & 10.75 \\
Std Dev & 0.5 & 20 & 2.8 & 18.38 & 19.81 & 19.86 \\
\hline
\end{tabular}




\section{Table L.2 CEO Compensation and its Economic and Governance Determinants}

The sample consists of 838 annual observations for acquiring and non-acquiring firms between 1997 and 2002. For acquiring firms, only one event is considered in case of multiple acquisitions by the firm in any year. In the regression model, the number of cases is less than 838 due to list-wise deletion of the cases with missing data. "CEO cash pay" is the sum of salary and annual cash bonus. "CEO total pay" is the sum of salary, cash bonus, and realized stock option pay in that year. The compensation data were obtained from management information circulars. As do Core et al. (1999), all independent variables are organized in two main categories: "Economic Determinants" and "Governance Variables".

Economic Determinants: Revenue is for the year prior to the year in which compensation is awarded. "Average price to book value" is over five years prior to the year in which CEO compensation was awarded. "Return on asset" is the percentage return on total asset for the prior year. "1-year Stock Return" is calculated based on year-end stock prices of the prior year. "Std. dev. of return on asset" is the standard deviation of the firm's return on asset over five prior years. "Std. dev. of stock return" is the standard deviation of 1-year stock return over four years prior to the year in which compensation was awarded.

Governance Variables: "CEO is related" is a dummy variable equal to " 1 " if the chair is related to management or the board, "0" otherwise. For example, if the CEO is also chair of the board, the dummy variable is equal to "1". "Percentage of inside directors" is the ratio of related directors to total board size. "Board size" is the number of directors on the board. "CEO ownership" is the percentage of outstanding shares owned by CEO. "Blockholder ownership" is the percentage of outstanding shares owned by individuals or institutions other than the directors. If the blockholder ownership is less than $10 \%$, the input value for this variable is " 0 ". "Director ownership" is the percentage of outstanding shares owned by all directors together. Beta coefficient value, t-statistics and significance level obtained through OLS regression are reported. Five dummy variables are included to control for the "year" effect and four dummy variables are included to control for the "industry" effect. Results for these dummy variables are not reported in the table. In order to avoid the extreme value (outlier) problem, the top $1 \%$ and bottom $1 \%$ of data for each variable in the regression model are deleted. 


\begin{tabular}{|c|c|c|c|}
\hline & & \multicolumn{2}{|c|}{ CEO Compensation Variable } \\
\hline & & Cash Pay & Total Pay \\
\hline \multicolumn{4}{|l|}{ 1. Economic Determinants } \\
\hline \multirow[t]{3}{*}{ Constant } & Beta & 84896.32 & 350721.30 \\
\hline & $t$-stat & 0.78 & 1.42 \\
\hline & Sig. & 0.44 & 0.16 \\
\hline \multirow{3}{*}{ Revenue (REV1) } & Beta & $0.09 * * *$ & $0.14 * * *$ \\
\hline & $t$-stat & 9.69 & 6.49 \\
\hline & Sig. & 0.00 & 0.00 \\
\hline \multirow[t]{3}{*}{ Avg. Price to Book Value (AVGPRBV) } & Beta & $19403.88^{* *}$ & $53927.86 * * *$ \\
\hline & $t$-stat & 2.28 & 2.63 \\
\hline & Sig. & 0.02 & 0.01 \\
\hline \multirow[t]{3}{*}{ Return on Asset (RASST1) } & Beta & $3280.03 * * *$ & $6363.89 * *$ \\
\hline & $t$-stat & 2.62 & 2.26 \\
\hline & Sig. & 0.01 & 0.02 \\
\hline \multirow[t]{3}{*}{ 1-year Stock Return (RET1) } & Beta & 7720.17 & 46594.20 \\
\hline & $t$-stat & 0.45 & 1.19 \\
\hline & Sig. & 0.65 & 0.23 \\
\hline \multirow[t]{3}{*}{ Std. Dev. of Return on Asset (STDROA) } & Beta & $-2896.60^{*}$ & $-7957.52 * *$ \\
\hline & $t$-stat & -1.65 & -2.01 \\
\hline & Sig. & 0.10 & 0.04 \\
\hline \multirow[t]{3}{*}{ Std. Dev. of Stock Return (STDRET) } & Beta & $-64909.53 * *$ & -28881.50 \\
\hline & $t$-stat & -2.19 & -0.43 \\
\hline & Sig. & 0.03 & 0.67 \\
\hline \multicolumn{4}{|l|}{ 2. Governance Variables } \\
\hline \multirow[t]{3}{*}{ Chair is related (CHRREL) } & Beta & 8648.73 & 29676.35 \\
\hline & $t$-stat & 0.22 & 0.34 \\
\hline & Sig. & 0.82 & 0.74 \\
\hline \multirow[t]{3}{*}{ Percentage of Inside Directors (PINDIR) } & Beta & $202549.15^{*}$ & 260169.02 \\
\hline & $t$-stat & 1.74 & 0.97 \\
\hline & Sig. & 0.08 & 0.33 \\
\hline \multirow[t]{3}{*}{ Board Size (BDSIZE) } & Beta & $52956.87 * * *$ & $49154.14 * * *$ \\
\hline & $t$-stat & 6.89 & 2.83 \\
\hline & Sig. & 0.00 & 0.00 \\
\hline \multirow[t]{3}{*}{ CEO Ownership (PCEOOWN) } & Beta & $5471.08 * * *$ & $4796.06^{*}$ \\
\hline & $t$-stat & 4.28 & 1.67 \\
\hline & Sig. & 0.00 & 0.10 \\
\hline \multirow[t]{3}{*}{ Blockholder Ownership (BLKOWN) } & Beta & $-3124.79 * * *$ & $-4608.33 * *$ \\
\hline & $t$-stat & -3.30 & -2.15 \\
\hline & Sig. & 0.00 & 0.03 \\
\hline \multirow[t]{3}{*}{ Director Ownership (DIROWN) } & Beta & $-5751.08 * * *$ & $-11377.34 * * *$ \\
\hline & $t$-stat & -4.56 & -3.99 \\
\hline & Sig. & 0.00 & 0.00 \\
\hline \multicolumn{2}{|l|}{$\mathbf{N}$} & 544 & 538 \\
\hline \multicolumn{2}{|l|}{ Adj. R square } & 0.45 & 0.22 \\
\hline \multicolumn{2}{|l|}{ F-Stat } & 22.01 & 8.01 \\
\hline \multicolumn{2}{|l|}{ Sig. } & 0.00 & 0.00 \\
\hline
\end{tabular}




\section{Results and Conclusion}

Results of the regression models are presented in Table L.2. Consistent with prior evidence and previous arguments, we find that CEO pay is an increasing function with revenue, average price to book value, and return on asset. That is, larger firms with better growth/investment opportunities and better past performance tend to pay more to a CEO. With respect to governance variables, we find that firms with larger board sizes and more inside directors (only for cash compensation) tend to pay higher CEO compensations. Further, consistent with the conjectures presented earlier, we find that blockholder ownership has a significant negative relationship with CEO compensation. Similarly, CEO ownership has a positive relationship with CEO cash compensation. However, the impact of CEO ownership on CEO total compensation, which also includes option pay, is marginal. This is consistent with the conjecture that CEOs with higher levels of stock ownership would not prefer option pay. In both regression models, dummy variables are included (not reported) to control for yearly variations and industry effects. Overall, the results show that a less effective (or weaker) governance system in a firm will lead to excess CEO pay. Therefore, CEO excess pay can be used as a reasonable proxy for CEO power or CEO hubris. 


\section{APPENDIX M: VARIABLE NAME AND DESCRIPTION}

\section{Part A: Firm Specific Variables}

"Average sales growth" is the average of an individual year's sales growth over five years prior to the year of acquisition.

"Cash flow to total asset" is the ratio of the firm's cash flow to total assets in the prior year.

"Growth or value" is a dummy variable. The value is " 1 " if the acquiring firm's price to book value ratio is greater than " 1 " and " 0 " otherwise.

"Leverage" is the ratio of (current liabilities + long term debt) to total assets in the prior year.

"Market value" is the year-end market value of the firm's equity as reported in the Stock Guide database. Unless otherwise described, market value has been used as a proxy for firm size.

"Price to book value" is the ratio of the firm's market value to book value in the prior year. 
"R\&D" intensity is the ratio of R\&D (research and development) expenditure to sales revenue in the prior year.

"Return on equity" is the ratio of net income to the net worth of firm in the prior year.

"Std. dev. of return on asset" is the standard deviation of the firm's return on asset over five prior years.

"Total assets" is the sum of all fixed and current assets of the acquiring firm as they appear in the balance sheet for the year prior to the year in which the acquisition is made.

\section{Part B: Governance variables}

"Blockholder ownership" is the percentage of outstanding shares owned by individuals or institutions other than the directors. If the blockholder ownership is less than $10 \%$, the input value for this variable is " 0 ". Three categories are created for blockholder ownership, namely, for less than $10 \%, 10-25 \%$, and more than $25 \%$.

"Board independence" is a dummy variable. The value is " 1 " if the majority of the board members are unrelated and " 0 " otherwise.

"Board size" is the number of directors on the board. 
"CEO cash pay" is the sum of salary and annual cash bonus.

"CEO hubris" is the CEO excess pay, which is the portion of CEO pay attributed to the firm's governance variables (see Appendix L for a detailed explanation). Two different forms of CEO excess pay are used in the regression: (i) CEO cash excess pay, and (ii) CEO total excess pay.

"CEO ownership" is the percentage of outstanding shares owned by the CEO. Three categories are created for CEO ownership, namely, for less than 5\%, 5-25\%, and more than $25 \%$.

"CEO total pay" is the sum of salary, cash bonus, and realized stock option pay in that year. The compensation data were obtained from management information circulars.

"Chair is related" is a dummy variable and is equal to " 1 " if the chair is related to management or the board, " 0 " otherwise. For example, if the CEO is also the chair of the board, the dummy variable is equal to " 1 ".

"Director ownership" is the percentage of outstanding shares owned by all directors (including the $\mathrm{CEO}$ ) of the firm. Three categories are created for director ownership, namely, for less than $5 \%, 5-25 \%$, and more than $25 \%$. 
"Pay ratio" is the ratio of the CEO's stock option value (CEO's aggregate realized option value in a year + CEO's unexercised option value) to cash pay.

"Percentage of inside directors" is the ratio of related directors to total board size.

\section{Part C: M\&A Deal Specific Variables}

"Cross border target (CrsBd2_3)" is a dummy variable. The value is "1" if the target is from outside Canada or the US and "0" otherwise.

"Deal size" is the total transaction value in millions of Canadian dollars.

"Payment type" or "Methods of payment" is a categorical variable outlining the nature of the transaction payment mode. Three categories are created: (i) cash payment (paytype1), (ii) stock payment (paytype2), and (iii) mixed or other (paytype3).

"Related/unrelated acquisition" is a dummy variable. For related acquisitions, the value is "1" and " 0 " otherwise. It is determined based on the SIC code of acquiring firms and target firms. Two versions of this dummy variable are created based on (i) 4-digit SIC code, and (ii) 2-digit SIC code.

"Relative size" is the ratio of the transaction value to the market value of the acquiring firm's equity. 
"Target Premium" is the gain to the target shareholders due to takeover announcements. Two methods are used to proxy for "target premium". First, we use a cumulative abnormal return for the target firm over " -30 days to +30 days" to calculate target premium (Crawford \& Lechner, 1996) ${ }^{83}$. Second, we calculate target premium using the offer price and pre-announcement stock price at "day -15 ", adjusting for market movement (St-Pierre, 1994) ${ }^{84}$.

"Target type" is a categorical variable outlining the nature of the target firm. Three categories are created: (i) public target (pubprv1), (ii) private target (pubprv2), and (iii) other (subsidiaries, joint ventures etc.) (pubprv3).

"Tender or merger" is a dummy variable. If the acquisition is completed through tender offer, the value is " 1 " and " 0 " otherwise.

\footnotetext{
${ }^{83}$ As pointed out by Crawford and Lechner (1996), there are a number of advantages for this approach: (i) the target premium can be calculated for all publicly traded targets irrespective of payment type, and (ii) it considers the wealth effect for target shareholders around the announcement date, thus giving a broader view of target premiums.

${ }^{84}$ Target premium $=\left(\left(\mathrm{OP}_{t}-\mathrm{P}_{\mathrm{t}-15}\right) / \mathrm{P}_{\mathrm{t}-15}\right)-\left(\left(\mathrm{I}_{\mathrm{t}}-\mathrm{I}_{\mathrm{t}-15}\right) / \mathrm{I}_{\mathrm{t}-15}\right)$, where, $\mathrm{OP}_{\mathrm{t}}=$ Price offered for the target shares at the announcement date. $\mathrm{P}_{\mathrm{t}-15}$ is the market value of the target shares 15 days prior to the announcement date. $I_{t}$ and $I_{t-15}$ are the Index value at the announcement date and 15 days prior to the announcement date respectively. This approach is applicable only for cash offers and listed target firms.
} 
Part D: Short- and long-run performance variables

\section{Short-run Performance Variables}

"AR" is the daily abnormal return based on the average difference in the return performance between the acquiring stock and the benchmark. "Adjusted AR" is the AR divided by the standard deviation of the AR. The standard deviation the AR also accounts for the first order correlation effect (please refer to Appendix F for details).

"CAR" is the average of the summation of the abnormal returns for each stock for a specific period. "Adjusted CAR" is the average of the summation of the adjusted AR for each stock divided by the square root of the number of days included in CAR. Six different versions of CAR are used in the analysis.

\section{Long-run Stock Return Performance Variables}

"BHAR" is the buy and hold abnormal return based on the average difference in the aggregated (compounded) performance between the included stock and the benchmark over a 36-month period, starting after the effective month of acquisition. "Value weight BHAR" is calculated based on the market value weight of the acquiring firm at the effective date of acquisition. Depending on the benchmark, six different BHARs are calculated. BHAR1 uses the equal weight matching firms' return as the benchmark. BHAR2 uses the value weight matching firms' return as the benchmark. "Matching firms" are the TSX firms that did not make any acquisition over the 1992-2003 period. BHAR3 uses the TSX 300 index as the benchmark. BHAR4 and BHAR5 use equal 
weight and value weight CFMRC index returns respectively as the benchmark. BHAR6 uses individual matching firm return as the benchmark. The individual marching firm is selected based on the nearest propensity score with respect to firm size and price to book value.

\section{Operating Performance Variables}

"Industry adjusted cash flow to total asset" is the average difference in the operating performance (cash flow to total asset) between the acquiring firm and the industry average for a given year relative to the acquisition year.

"Industry adjusted post average cash flow to total asset" is the average of "Industry adjusted cash flow to total asset" for the post acquisition period (year $+1,+2$ and +3 ).

"Industry adjusted pre average cash flow to total asset" is the average of "Industry adjusted cash flow to total asset" for the pre acquisition period (year $-1,-2$ and -3 ).

"Industry adjusted post and pre difference" is the average of the difference between "Industry adjusted post average cash flow to total asset" and "Industry adjusted pre average cash flow to total asset".

"Matching firm adjusted cash flow to total asset" is the average difference in the operating performance (cash flow to total asset) between the acquiring firm and the matching firm for a given year relative to the acquisition year. The individual matching 
firm is selected based on the nearest propensity score with respect to firm size and price to book value.

"Matching adjusted post average cash flow to total asset" is the average of "matching firm adjusted cash flow to total asset" for the post acquisition period (year $+1,+2$ and $+3)$.

"Matching adjusted pre average cash flow to total asset" is the average of "Matching firm adjusted cash flow to total asset" for the pre acquisition period (year $-1,-2$ and -3 ).

"Matching firm adjusted post and pre difference" is the average of the difference between "Matching adjusted post average cash flow to total asset" and "Matching adjusted pre average cash flow to total asset". 